Faculdade de Filosofia, Letras e Ciências Humanas

Departamento de História

Programa de Pós-Graduação em História Social

\author{
"Cego é aquele que só vê a bola." \\ O futebol em São Paulo e a formação das principais \\ equipes paulistanas: S. C. Corinthians Paulista, S. E. \\ Palmeiras e São Paulo F. C. \\ (1894-1942)
}

João Paulo França Streapco

Dissertação apresentada ao Programa de PósGraduação em História Social do Departamento de História da Faculdade de Filosofia, Letras e Ciências Humanas da Universidade de São Paulo

Professora Orientadora: Dr. ${ }^{a}$ Raquel Glezer

V.1

São Paulo

2010 


\begin{abstract}
Universidade de São Paulo
Faculdade de Filosofia, Letras e Ciências Humanas

Departamento de História
\end{abstract}
Programa de Pós-Graduação em História Social
Dissertação de mestrado.

\title{
"Cego é aquele que só vê a bola". O futebol em São Paulo e a formação das principais equipes paulistanas: S. C. Corinthians Paulista, S. E. Palmeiras e São Paulo F. C. (1894-1942)
}

\author{
João Paulo França Streapco
}

Dissertação apresentada ao Programa de PósGraduação em História Social do Departamento de História da Faculdade de Filosofia, Letras e Ciências Humanas da Universidade de São Paulo.

Prof $^{a}$ Orientadora: Dra. Raquel Glezer 


\section{Resumo}

Nos últimos anos, os estudos sobre a prática do futebol no Brasil se avolumaram em diversas áreas do saber. Compreendido como um fenômeno de largo alcance social, o futebol que antes era desprezado pela intelectualidade, tornou-se espaço privilegiado para a compreensão de diversos fenômenos sociais correlatos. Não obstante ao desenvolvimento dessas pesquisas, diversas fontes documentais produzidas pelo universo futebolístico ao longo do século XX, ainda não tinham sido analisadas com rigor sistemático. Assim, esse trabalho ao se inserir em um contexto de renovação historiográfica denominada Nova História Cultural, busca compreender algumas facetas da sociedade paulistana que estiveram presentes em seus principais campos, equipes e estádios de futebol no período estudado (1894-1942). A formação de um circuito de praticantes e simpatizantes, a intervenção do poder público, a construção de campos e estádios, o surgimento dos três principais clubes de futebol da cidade, as disputas pelo controle das rendas geradas pelo espetáculo e sua profissionalização, mostraram-se como excelentes fontes documentais para a compreensão da complexidade do processo de modernização ocorrido em São Paulo e suas consequências para seus habitantes, no período abarcado pela pesquisa.

Palavras chaves: Cidade de São Paulo, identidade, futebol, invenção das tradições e cultura popular. 


\begin{abstract}
In recent years, many studies on the practice of football in Brazil have been carried out in different areas of knowledge. Understood as a broad-ranging social phenomenon, football - which was once despised by intellectuals and academia - has become a privileged source for the study of many interconnected social phenomena. Despite the development of said studies, many documentary sources produced in the world of football throughout the twentieth century still have not been systematically assessed. Hence, because this study is part of context of historiographical renewal referred to as New Cultural History, its objective is to further understand certain aspects of the São Paulo society present in the main football fields, teams and stadiums with respect to the period subject matter hereof (1894 - 1942). The establishment of a group of practitioners and supporters, together with government intervention, the construction of fields and stadiums, the emergence of three major football clubs in the city, disputes over control of revenues generated by the sport itself and its gradual pathway towards becoming increasingly professional reveal to be excellent documentary sources for better understanding the complexity of the modernization process that took pplace in São Paulo and the consequences thereof for its citizens during the period covered in this study.
\end{abstract}

Key words: City of São Paulo, identity, football, invention of traditions and popular culture. 


\section{AGRADECIMENTOS}

O texto que segue é resultado de um projeto de pesquisa que durou cerca de seis anos, desde o momento em que foi esboçado, em março de 2004, até o momento em que o entrego para a banca examinadora. Creio não ser necessário indicar que sua realização contou com contribuições de muitas pessoas, como funcionários das bibliotecas e dos arquivos que visitei em busca das informações, colegas dos corredores do Departamento de História e dos grupos de estudo que frequentei enquanto elaborava a pesquisa, tantos foram os amigos fundamentais que corro o risco de cometer algumas injustiças por não saber seus nomes, não me lembrar de todos, e, por isso, não citá-los.

Gostaria, no entanto, de agradecer a algumas pessoas que contribuíram de forma incisiva nos caminhos que percorri na pesquisa e nos contornos que o trabalho adquiriu. Primeiramente, minha orientadora, Dr. ${ }^{a}$ Raquel Glezer, que me recebeu em sua sala, acreditou no projeto e, pacientemente, me ajudou ao longo dos últimos quatro anos.

Do Departamento de História, Marly Spachacieri foi uma grande amiga que me ajudou com as questões burocráticas da universidade, assim como as professoras Dr. ${ }^{\text {a }}$ Vera Lúcia do Amaral Ferlini e Dr. ${ }^{a}$ Sara Albieri me orientaram nos estágios PAE. A elas agradeço pelo privilégio do convívio nas noites de sextas-feiras, ao longo de um ano. Thiago Nicodemo foi um grande interlocutor com quem compartilhei minhas angústias e dúvidas, e de quem recebi dicas e sugestões em momentos cruciais do trabalho. A reprodução das imagens obtidas ao longo da pesquisa só foi possível por causa do trabalho de Magno Nascimento. Sem a preciosa ajuda de Christina Rostworowski da Costa, a versão inglesa do resumo seria muito precária.

Os professores Dr. ${ }^{a}$ Esmeralda Blanco Bolsonaro de Moura, Dr. ${ }^{a}$ Kátia Rúbio e Dr. Marco Silva contribuíram com importantes sugestões com as disciplinas que ministraram e que tive a oportunidade de cursar. Agradeço ainda à professora Dr. ${ }^{a}$ Esmeralda Blanco Bolsonaro de Moura e ao professor Dr. José Paulo Florenzano por suas leituras cuidadosas e criteriosas quando apresentei o relatório de qualificação deste trabalho, no início de 2009.

Aos colegas do Grupo de Literatura e Memória do Futebol - Memofut, em especial, ao Sr. Domingos D’ Ângelo, ao jornalista Celso Dário Unzelte e a Marcelo Dentello, que me permitiram consultar suas coleções particulares. Aos colegas de Grupo de Estudos Interdisciplinares do Futebol da USP - GIEF/USP, em especial à Diana Mendes Machado da Silva, Sérgio Settani Giglio, Enrico Spaggiari e Marcel Diego Tonini, que acompanharam a pesquisa, leram o texto e fizeram sugestões importantes. A leitura atenta de Dalton Monteiro Rodrigues permitiu a correção de diversos erros que eu já não conseguia enxergar.

À minha tia e meus irmãos, pelo apoio financeiro, indispensável, nas horas mais difíceis. E aos meus pais, por me ensinarem a cultuar os livros e o Corinthians. 
À Lydiane. 


\section{Sumário}

$\begin{array}{ll}\text { Introdução } & 7\end{array}$

Parte I. Os donos da história do futebol em São Paulo............................................ 11

1. Entre os campos, praças desportivas e estádios. Alguns dos espaços utilizados para o futebol na cidade de São Paulo.

1.1 A formação dos múltiplos espaços dedicados ao futebol na cidade de São Paulo e a atuação do poder público.

1.2 Improviso, colaboração e segregação. As relações entre futebol de várzea e o futebol oficial.

2. Polissemia. O futebol e seus múltiplos significados na sociedade paulistana..

2.1 Além do elitismo das primeiras ligas.

$2.2 \mathrm{O}$ papel dos negros e descendentes de imigrantes no processo de ressignificação do futebol paulistano.

Parte II. Formou-se o eixo do futebol paulistano.

3. São Paulo Futebol Clube. O time herdeiro do futebol elitista do início do século $\mathrm{XX}$ ?

3.1 O desaparecimento dos clubes de elite dos campeonatos de futebol e o imaginário tricolor.

3.2 São Paulo da Floresta e São Paulo Futebol Clube. A mesma equipe ou equipes diferentes?

3.3 A década de ouro do Pacaembu e a formação do trio de ferro..

4. Sociedade Esportiva Palmeiras. O time unificador da colônia italiana em São Paulo?

4.1 As relações do Palestra Itália com outras equipes da comunidade italiana de São Paulo

4.2 As relações com a família Matarazzo e outros industriais italianos.

4.3 Da Sociedade Esportiva Palestra Itália à Sociedade Esportiva Palmeiras.

5. Sport Club Corinthians Paulista. O único time das massas?.

5.1 A abertura do Corinthians à comunidade negra de São Paulo...

$5.2 \mathrm{O}$ time que popularizou o futebol?..

5.3 Mais do que a caminho da zona leste, às margens do rio Tietê.

Considerações finais.

Fontes..

Bibliografia.

Sítios da Internet. 


\section{Introdução}

Em A História Cultural. Entre Práticas e Representações, Roger Chartier afirma que um trabalho de história cultural tem por principal objetivo identificar o modo como, em diferentes lugares e momentos, uma determinada realidade social é construída, pensada, dada a ler ${ }^{1}$. Segundo ele, os caminhos para essa compreensão devem levar em consideração variáveis como classes sociais, meios intelectuais, todas as disposições estáveis e partilhadas, próprias do grupo, porque são esses esquemas intelectuais que criam as figuras graças às quais o presente pode adquirir sentido, o outro tornar-se inteligível e o espaço ser decifrado.

Os estudos sobre o futebol, que se avolumaram na última década, são resultados dos desdobramentos produzidos pela chamada Nova História Cultural, escola historiográfica que chamou a atenção para determinadas práticas pouco valorizadas até então por historiadores ${ }^{2}$. Há um volume grande de obras dedicadas à história do futebol que foi produzido por jornalistas como resultado da paixão pelo esporte e não possuem uma discussão mais ampla e profunda. Tais obras são fundamentais para a preservação da memória dessas práticas e ajudam a consolidar as representações do futebol que hoje conhecemos.

No Brasil, onde a população começou a ser alfabetizada e teve acesso à escolarização em massa a partir da segunda metade do século XX, em que imigrantes e brasileiros pobres não dominavam a norma culta da língua oficial, os meios e disposições estáveis partilhados pela população para a produção de representações não se restringiram a obras escritas. As práticas corporais, como a música, a dança, a gestualidade ou o jogo de futebol, foram fundamentais na construção de representações.

Sobre o futebol, Nelson Rodrigues publica em uma crônica a afirmação:

"Certo e brilhante confrade dizia-me ontem que futebol é bola. Não há juízo mais inexato, mais utópico, mais irrealístico. O colega esvazia o futebol como

\footnotetext{
${ }^{1}$ CHARTIER, Roger. A história cultural. Entre práticas e representações. Rio de Janeiro, Difel/Bertrand, 1988. Pág. 16.

${ }^{2}$ DEL PRIORE, Mary \& MELO, Victor Andrade de. História do esporte no Brasil. São Paulo, Unesp. Pág. 9.
} 
um pneu, e repito: - retira tudo que ele tem de misterioso e de patético. A mais sórdida pelada é de uma complexidade shakesperiana. Às vezes, num corner mal ou bem batido, há um toque de evidentíssimo sobrenatural. Eu diria ainda ao ilustre confrade o seguinte: - em futebol, o pior cego é o que só vê a bola." 3

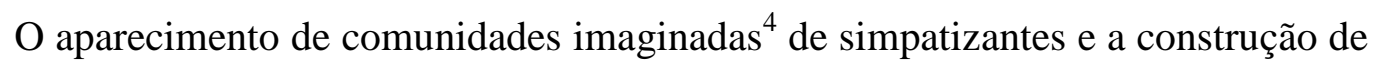
novas identidades na sociedade paulistana por intermédio do futebol ocorreram como consequência do processo acelerado de modernização que a cidade passou nas últimas décadas do século XIX e nas primeiras décadas do século XX, através do qual os habitantes perderam diversos referenciais identitários tradicionais e tiveram a necessidade de construir novas identidades.

A proposta desta pesquisa, em sua origem, era refletir como se deu a apropriação de uma prática cultural vinda do exterior pela população paulistana na virada do século XIX para o XX e de que maneira tal apropriação criou um grande fenômeno social. O desenvolvimento da pesquisa, no entanto, obrigou-nos a ampliar o referencial teórico e a adotar referenciais analíticos de outras correntes historiográficas, não apenas as da Nova História Cultural, porque percebemos a formação de uma rede complexa e estruturante de relações econômicas, políticas e sociais nos espaços dedicados ao futebol, ao longo do período abarcado por esta pesquisa.

Assim, o trabalho que segue se propõe a verificar algumas características importantes do futebol, tais como os fatos de extrapolar a esfera exclusiva do esporte ou jogo, se mesclar com outras demandas sociais e culturais já estudadas pela historiografia e ter sido pouco analisado e interpretado pela historiografia brasileira.

As percepções do social que constroem representações não são neutras, produzem estratégias e práticas que tendem a impor uma autoridade à custa de outras, a legitimar ou justificar aos indivíduos suas escolhas e condutas e traduzem as posições e interesses à revelia dos autores, tal como pensam que elas são ou gostariam que

\footnotetext{
${ }^{3}$ RODRIGUES, Nelson. "O divino delinquente”. (In): À sombra das chuteiras imortais. Pág. 103.

4 ANDERSON, Benedict. Comunidades Imaginadas. São Paulo, Cia. das Letras, 2008. O livro foi concebido para discutir identidades nacionais. As bases que fundamentam a identidade nacional apresentam semelhanças com aquelas que fundamentam o sentimento de pertencimento a uma torcida de futebol. Ver, em especial, a apresentação da professora Lilia Moritz Schwarcz: Imaginar é difícil (porém necessário).
} 
fossem $^{5}$. Daí, o potencial oferecido pelo estudo do futebol para a compreensão das relações sociais entre grupos subalternos da sociedade brasileira e as elites econômicas, políticas ou culturais se assemelha aos estudos sobre a música e a dança populares nos séculos XIX e XX, pois foi dessa maneira que quase toda a sociedade pôde se manifestar, que a maior parte da população brasileira conseguiu transmitir saberes e a própria memória aos seus descendentes e perpetuar sua identidade e transmiti-la às gerações mais novas, superando as restrições encontradas no acesso à cultura dita oficial ou de elite.

Na apresentação de seu livro Chão de terra e outros ensaios sobre São Paulo, Raquel Glezer indaga

"Onde estão os homens que fazem a história? Onde estão as imagens que possibilitam alguma identificação do passado? Afinal, qual é o problema da cidade?" 6

E conclui seu raciocínio afirmando que

"os homens, em nosso entender, fizeram e fazem a cidade, produto material e imaterial das relações sociais e econômicas complexas, mesmo que não saibam o que fizeram ou estão fazendo. São atores, agentes da ação social, mas nem sempre em condições de compreender a totalidade e complexidade do fenômeno em que estão inseridos e atuando." 7

Aqueles que se dedicaram ao futebol foram e são agentes de sua própria história, construíram imagens que possibilitam a compreensão do passado, mesmo que não compreendessem a totalidade e complexidade do fenômeno em que se inseriam, fizeram e fazem a cidade através dos aspectos materiais e imateriais que o esporte possibilita aos seus praticantes e simpatizantes.

${ }^{5}$ CHARTIER, Roger. A história cultural. Op. Cit. Págs. 17, 18 e 19.

${ }^{6}$ GLEZER, Raquel. Chão de terra e outros ensaios sobre São Paulo. São Paulo, Alameda Editorial, 2007. Pág. 14.

${ }^{7}$ GLEZER, Raquel. Idem, ibidem. Op. Cit. Pág. 14. 
Analisamos diversos aspectos que se relacionam com o futebol: a rede de vigilância que se estendeu sobre os praticantes e como esses não se conformaram com ela e a alteraram na construção do próprio cotidiano em um período histórico definidor das estruturas urbanas e sociais da metrópole; os múltiplos dispositivos utilizados pela população para a construção de diversas identidades e as representações que dão suporte a algumas delas; e a trajetória das três principais equipes da cidade. Enfim, utilizamos as representações produzidas pelos aficionados por futebol para compreender um pouco mais da história da cidade de São Paulo e de seus habitantes, dentro do proposto por Nelson Rodrigues. 


\section{PARTE I}

"Os donos da história do futebol em São Paulo". 


\section{Entre campos, praças desportivas e estádios. Alguns dos espaços utilizados para o futebol na cidade de São Paulo.}

\subsection{A formação dos múltiplos espaços dedicados ao futebol na cidade de São Paulo e a atuação do poder público.}

O futebol é um esporte que exige espaços amplos para a abertura de campos nos quais os jogadores possam disputar as partidas. Isso acontece em um simples campo de futebol de várzea ou com o estádio e suas arquibancadas. É preciso salientar, entretanto, que, entre um simples campo de terra batida e o grande estádio, existem diferenças simbólicas e materiais fundamentais que analisaremos nas próximas páginas e que condicionam como as pessoas concebem ou praticam o futebol. Pela análise dessas diferenças, percebemos que o futebol em São Paulo nem sempre teve a dimensão alcançada na década de 1940, quando o Estádio Municipal do Pacaembu foi inaugurado.

A história desses espaços pode indicar pistas importantes acerca da cultura, dos mecanismos de controle criados pela administração pública para vigiar a prática do futebol e da urbanização de São Paulo, e, em especial, dos processos de especulação imobiliária que ocorreram no período.

No trabalho apresentado em Seminário Internacional em 2004, os geógrafos Gilmar Mascarenhas e Christopher Gaffney afirmam que os estádios de futebol apresentavam significados cambiantes, ${ }^{8}$ estrategicamente disseminados por governos autoritários como monumentos que celebram o poder e o prestígio. ${ }^{9}$

No breve histórico dos estádios no ocidente, os autores afirmam que os estádios são memória acumulada, vivida coletivamente, na medida em que são templos gigantes com dimensão sagrada, cujo formato circular evoca o eterno retorno dos tempos, exercício facilmente associado ao ciclo das competições e temporadas esportivas, e

\footnotetext{
${ }^{8}$ GAFFNEY, Christopher e MASCARENHAS, Gilmar. O estádio de futebol como espaço disciplinar. Seminário Internacional Michel Foucault - Perspectivas In: Anais. Florianópolis, Universidade Federal de Santa Catarina, 21 a 24 de dezembro de 2004. Pág.2.

${ }^{9}$ GAFFNEY, Christopher e MASCARENHAS, Gilmar. Op. Cit. Pág. 2.
} 
transformam-se na Meca de cânticos profanos que proporciona ao indivíduo que nele ingressa a suspensão do tempo externo. ${ }^{10}$

A prática do futebol na cidade de São Paulo começou de forma modesta na várzea do Carmo e em algumas chácaras do bairro do Bom Retiro, regiões que no final do século XIX, estavam fora do perímetro urbano da cidade. Entre a introdução do esporte e a construção do estádio do Pacaembu, outros espaços da cidade foram utilizados para a prática do futebol, mas a ideia de um estádio geometrizado na forma unificada de grandes anéis maciços, como o definido por Mascarenhas e Gaffney ou por Georges Vigarello, na obra História do Corpo v.3, ${ }^{11}$ só se consolidou em São Paulo, no final dos anos 1930, com a inauguração do Estádio Municipal, no bairro do Pacaembu.

Nesta parte do trabalho, analisaremos os mecanismos utilizados pelo poder público para tentar controlar a prática do futebol e de outras modalidades esportivas e a trajetória que transformou uma simples atividade de lazer em um dos grandes monumentos da cidade. Para isso, apresentamos e discutimos as leis municipais que tentaram restringir o futebol nas ruas, ao mesmo tempo em que criaram espaços específicos para a sua prática, para poder entender a dinâmica que permitiu o aparecimento dos campos de várzea, praças desportivas e o estádio municipal.

Cada um dos espaços citados adquiriu significados para os adeptos do futebol, que serão discutidos no decorrer desse trabalho. Nem todos os espaços destinados ao futebol tiveram a monumentalidade do Estádio Municipal, situação que não nos impede de os entendermos como monumentos/documentos. ${ }^{12} \mathrm{O}$ monumento é um sinal do passado, é tudo aquilo que pode evocar o passado, perpetuar a recordação, e serve como suporte da memória coletiva de uma sociedade e suas relações de poder.

\footnotetext{
${ }^{10}$ GAFFNEY, Christopher e MASCARENHAS, Gilmar. Op. Cit. Pág. 4.

11 VIGARELLO, Georges. O espetáculo esportivo das arquibancadas às telas. (In) CORBIN, Alain; COURTINE, Jean-Jacques e VIGARELLO, Georges. História do corpo. Vol. 3: As mutações do olhar. O século XX. Petrópolis, Vozes, 2008. Pág. 445; afirma-se que os estádios só se consolidam na Europa com este formato na virada do século XIX para o XX. Até então, "no coração dos primeiros esportes não se acha o espetáculo. O espaço do estádio continua sendo, durante muito tempo, contingente, atravancado, no meio de árvores ou de auxiliares diversos, cercado de linhas mal definidas, de natureza indeterminada."

${ }^{12}$ LE Goff, Jacques. História e Memória. Pág. 526. Le Goff define como características do monumento o "ligar-se ao poder de perpetuação, voluntária ou involuntária, das sociedades históricas (é um legado à memória coletiva) e reenviar a testemunhos que só numa parcela mínima são testemunhos escritos."
} 
Os estádios de futebol da cidade consolidaram-se com triplo significado: locais de memória do processo de modernização/urbanização vivenciado na cidade por seus habitantes no período estudado, templos ritualísticos que consolidam a identidade de um grupo de simpatizantes/torcedores e espaços de expressão e concentração de poder. ${ }^{13}$

Lembramos que os mecanismos de controle nem sempre funcionaram ou funcionam, como podemos inferir atualmente da atuação das chamadas torcidas organizadas; no decorrer do trabalho, mostraremos que, desde a década de 1930, a violência já existia nos campos da cidade, muito antes do aparecimento dessas torcidas. No período estudado, era comum os clubes manterem suas sedes sociais em locais separados das praças de esporte, normalmente no centro da cidade.

Quando chegou a São Paulo e apresentou o futebol aos colegas do São Paulo Athletic Club (SPAC ou Clube dos Ingleses) e aos funcionários da São Paulo Railway, entre 1894 e 1895, Charles Miller se utilizou de dois espaços que considerou os mais adequados para jogar futebol: a várzea do Carmo, na qual realizou alguns treinamentos com os colegas de trabalho, e a Chácara Dulley, no bairro do Bom Retiro, que, naquela época, era utilizada pelos sócios do São Paulo Athletic Club para a prática do rricket $^{14}$.

Além dos britânicos, algunss estudantes do Mackenzie, que fundaram um time de futebol na escola, a Associação Athlética Mackenzie College de São Paulo, membros da comunidade alemã de São Paulo, outros estudantes do Mackenzie, que fundaram o Sport Club Internacional, e o Sport Club Germânia - atual Esporte Clube Pinheiros disputaram partidas na mesma chácara, entre 1898 e 1899. Segundo Alfredo Oscar Salun, as primeiras partidas entre clubes só começaram a ser disputadas em março de 1899. ${ }^{15}$

\footnotetext{
${ }^{13}$ Por uma questão de periodização, centraremos nossa análise no Estádio Municipal do Pacaembu, sem deixar de reconhecer a importância do Estádio do Morumbi (pertencente ao São Paulo Futebol Clube) e do Palestra Itália (pertencente à Sociedade Esportiva Palestra Itália e que será apresentado e discutido como Praça de Esportes, pois sua transformação em Estádio ocorre num período histórico posterior).

${ }^{14}$ A chácara pertencia à família Dulley, que a emprestava ao SPAC para a realização de atividades externas que exigiam campos extensos e abertos.

${ }^{15}$ SALUN, A. O. Palestra Itália e Corinthians. Quinta coluna ou tudo buona gente? Tese de doutorado apresentada ao Dep. de História da FFLCH - USP, 2007. Pág. 25.
} 
Entre 1899 e 1906, a Chácara Dulley foi loteada e arruada, depois de concedida a isenção de impostos por cinco anos pela Prefeitura para que a família proprietária o fizesse e entregasse à municipalidade ruas para o trânsito público. ${ }^{16}$

Durante alguns meses, os jogadores do Germânia e do Internacional utilizaramse de uma chácara vizinha, a Chácara Witte. ${ }^{17}$ Não podemos verificar com exatidão o momento em que a Chácara Witte foi loteada, mas tudo indica que teve o mesmo destino da Chácara Dulley naquela ocasião, pois esse foi o período em que o Germânia passou a mandar seus jogos no Parque Antarctica, enquanto o SPAC arrendou um terreno nos arredores da rua da Consolação e os estudantes do Mackenzie passaram a utilizar o pátio do colégio de maneira improvisada.

Principal espaço utilizado por Miller e por toda comunidade britânica para a prática do futebol e do cricket, a Chácara Dulley desapareceu no processo de urbanização nos primeiros anos do século XX e se transformou em ruas e quarteirões que receberam um grande contingente de imigrantes italianos nos anos seguintes, no bairro do Bom Retiro. Mas, do convívio dos jogadores de futebol na Chácara Dulley, surgiu, em 1902, no Velódromo Paulista, o chamado futebol oficial, por intermédio da organização do primeiro campeonato paulista de futebol e da criação da Liga Paulista de Futebol (LPF), formada apenas por equipes de jovens burgueses de origem estrangeira ou nacional.

No mesmo período, os jovens que não pertenciam à burguesia paulistana se articulavam na várzea do Carmo, formando novos times que deram origem ao futebol não oficial, também conhecido como varzeano ou de várzea, que, ao se espalhar por toda a cidade, generalizou o termo para todo e qualquer campo de futebol existente nos bairros.

\footnotetext{
${ }^{16}$ Lei $n .{ }^{\circ} 414,28 / 08 / 1899$. A lei dava um prazo de dezoito meses para a conclusão das obras, caso contrário a medida perderia sua validade e anulava a isenção de impostos municipais para os terrenos que fossem vendidos na sequência do arruamento. Também atribuía à Prefeitura autorização para a ocupação desses terrenos e a denominação das ruas e praças abertas no loteamento. Segundo a lei n. ${ }^{\circ} 959$ de 19/11/1906, a rua foi cercada e loteada a partir de 1906. As leis estão no Relatório de Governo do Senhor Prefeito Antonio da Silva Prado, entregue à Câmara Municipal ao término de sua gestão, em 1911. São Paulo, Seção de Obras Raras da Biblioteca Mário de Andrade.

${ }^{17}$ MAZZONI, Thomaz. História do futebol no Brasil. Pág. 24. O autor afirma que o Sport Club Internacional mandou seus jogos na Chácara Dulley por alguns meses, migrando na sequência para a Chácara da Floresta. Por enquanto, não foi possível descobrir os caminhos que levaram o clube para a Ponte Grande, no rio Tietê. As fontes também não informam como o Germânia entrou em acordo para utilizar o Parque Antarctica.
} 
Alguns autores sugerem que a intervenção pública nos meios futebolísticos só aconteceu mediante a projeção internacional que os desportistas brasileiros adquiriram. ${ }^{18}$ As fontes consultadas sugerem situação distinta.

Em decorrência da apropriação do futebol pelas camadas mais pobres desde os primórdios do século XX, em São Paulo, as autoridades públicas tentaram controlar e regulamentar sua prática, quer por intermédio do poder municipal que cerceava a prática por meio da legislação, quer pela construção ou determinação de espaços considerados apropriados, genericamente denominados por alguns cronistas como praças de esportes. $^{19}$

Em 1904, o prefeito Antonio Prado, cujo filho foi um dos idealizadores do Club Athlético Paulistano e a mãe a construtora do Velódromo Municipal, regulamentou a prática do futebol na cidade pela Lei $n .^{\circ} 702:^{20}$

Art.1. ${ }^{\circ}$ - Fica o Prefeito auctorizado a regulamentar o divertimento do foot-ball, de maneira a serem resguardadas as pessoas e propriedades de quaesquer offensas ou damnos.

Art. 2. ${ }^{o}$ - O campo de foot-ball será estabelecido de maneira a seus limites guardarem sempre uma distancia nunca menor de 20 metros das casas, jardins, propriedades de terceiros, ruas e praças publicas, e será separado do resto do terreno por uma téla de arame pelo menos, construída à custa das pessoas ou associações que mantiverem o divertimento.

$\S$ Quando os limites do campo de foot-ball forem um outro campo ou quando ficarem á distancia maior de 30 metros das propriedades de terceiros e ruas ou praças, será dispensada a cerca por meio de téla de arame.

Art.3. ${ }^{\circ}$ - Os infractores da lei e regulamento ficam sujeitos á multa de $20 \$ 000$ e do dobro nas reincidencias.

Em 1923, mais uma vez a Prefeitura tentou controlar a prática do futebol, por meio de nova regulamentação, criada com termos muito parecidos com os da lei de 1904, com multa de $20 \$ 000$ e o dobro em caso de reincidência, ${ }^{21}$ com um artigo novo

18 NEGREIROS, Plínio José Labriola de Campos. Resistência e rendição. A gênese do Sport Club Corinthians Paulista e o futebol oficial de São Paulo (1910 - 1916). Pág. 24.

${ }^{19}$ MAZZONI, Thomaz. Op. Cit. Pág. 125. Ao se referir ao primeiro campo do Corinthians, o autor afirma: Nesse ano de 1918, o Corinthians inaugurou sua primeira praça de esportes, situada ao lado da Floresta. Outros exemplos são recorrentes no livro.

${ }^{20}$ Relatório de Governo do Senhor Prefeito Antonio da Silva Prado, Op. Cit.

${ }^{21}$ Acto n. ${ }^{\circ}$ 2007, de 28/04/1923. "Art.1. - Os campos de football serão estabelecidos de maneira a seus limites guardarem sempre uma distancia nunca menor de 20 metros das casas, jardins, propriedades de terceiros, ruas e praças publicas. $\S 1 .^{\circ}$ - Esses campos devem ser separados do resto do terreno por uma 
que proibia o jogo de futebol nas ruas e praças da cidade. A edição da nova lei é um forte indicativo de que a lei anterior se transformara em letra morta ou que não era respeitada pelos munícipes.

No início do século $\mathrm{XX}$, apenas alguns espaços eram considerados adequados pelo poder público para o futebol, mas nada havia que lembrasse os grandes anéis maciços de Vigarello: o Velódromo Municipal, que ficava nas adjacências da igreja da Consolação e do Colégio Mackenzie; o pátio de algumas escolas, todas frequentadas pela elite paulistana, em especial o pátio do próprio Colégio Mackenzie, a sede adquirida pelo SPAC nos arredores da Caixa d'Água da rua da Consolação e o Parque Antarctica, que ficava em uma região distante do centro, no atual bairro da Água Branca. Esses espaços foram utilizados pela Liga Paulista de Futebol na realização das partidas do primeiro campeonato, em 1902. Nos anos seguintes, os dois campos maiores passaram a ter preferência para a disputa das partidas do futebol oficial na cidade e serviram de referência para a construção das praças de esportes da cidade, contrapondose à várzea do Carmo e ao futebol varzeano. ${ }^{22}$

Em sua inauguração, em 21 de junho de 1896, o Velódromo de São Paulo recebeu a visita de algumas personalidades paulistas da época, como o então Governador do Estado, Manuel Ferraz de Campos Salles e Raphael de Barros, um dos fundadores do Jockey Club de São Paulo, que foram prestigiar as corridas de bicicleta disputadas pela mocidade da cidade. ${ }^{23}$ Dentre os corredores, destacava-se Antonio Prado Júnior, um dos netos a quem sua avó, dona Veridiana Prado, resolvera presentear com a construção de uma pista de corrida de bicicletas em um dos terrenos resultantes

tela de arame pelo menos, construída á custa das pessoas ou associações que mantiverem o divertimento. $\S 2 .^{\circ}$ - Quando os limites do campo de foot-ball forem um outro campo ou quando ficarem á distancia maior de 30 metros das propriedades de terceiros e ruas e praças, será dispensada a cerca a que se refere o paragrapho antecedente. Art.2..$^{\circ}$ - Fica expressamente prohibido o jogo livre de foot-ball nas ruas e praças da cidade. Art.3..$^{\circ}$ - Os infractores ficam sujeitos á multa de $20 \$ 000$ e do dobro nas reincidências. Paragrapho único - A multa referida neste art. será cobrada individualmente". Relatório de Governo enviado à Câmara Municipal pelo Senhor Prefeito Firmínio de Moraes Pinto, em 1925. Seção de Obras Raras da Biblioteca Municipal Mário de Andrade - SOR - BMMA.

22 MAZZONI, Thomaz. Op.Cit. Págs. 38 e 39. O autor informa apenas que, aos poucos, o campo do SPAC deixou de ser utilizado. No campeonato de 1903, já deixara de ser utilizado, voltando a ser utilizado em 1904 para algumas partidas. Não indica, no entanto, os motivos de tais ocorrências, mas tudo leva a crer que a estrutura da sede do SPAC não comportava o público que começava a frequentar as partidas de futebol. O mesmo deveria ocorrer com o pátio do Colégio Mackenzie, pois já em 1903, as partidas da A.A. Mackenzie College eram disputadas no Velódromo Paulista.

${ }^{23}$ Uma reminiscência interessante: A inauguração do Velódromo. Diário da Noite. Coleção Caio Prado Jr, IEB-USP, sem data. 
da partilha de sua chácara. O projeto foi encomendado a Tommazzo Gaudêncio Bezzi, em 1886, e reservava espaço para cerca de 1.000 pessoas acompanharem as corridas, com um bar, depósito e área de apostas, pois, além de divertir seus netos, D. Veridiana pretendia ganhar dinheiro com apostas, de forma semelhante ao que ocorria no hipódromo com os cavalos. E a família Prado passou a ganhar dinheiro com o futebol, cobrando um aluguel mensal de 250\$000 para os sócios do Club Athlético Paulistano utilizarem o espaço. $^{24}$

A pista era uma grande raia de forma elíptica, com 380 metros de comprimento e oito de largura, ${ }^{25}$ fora do perímetro urbano, e quando se esgotou o modismo do ciclismo na cidade, o amplo jardim central foi convertido em campo de futebol, a partir de 1901, após a fundação do Clube Athlético Paulistano e a adoção do futebol pelos seus sócios em meados daquele ano. ${ }^{26}$ Transformou-se em espaço no qual os jovens abastados desfilavam suas habilidades para as moças das famílias ricas. ${ }^{27}$ Mas, então, o Velódromo já estava englobado pela mancha urbana e a antiga pista de corrida, abandonada, virou uma espécie de arquibancada geral, na qual as pessoas podiam assistir a partidas de futebol encostadas no alambrado, em pé, junto ao gramado. Frequentar o Velódromo era mais que participar de um jogo de futebol, era uma atividade social, na qual os jovens da burguesia se mostravam e eram vistos.

Os acessos às arquibancadas cobertas e ao gramado eram restritos e a população pobre apenas tinha acesso à arquibancada geral. Tornou-se a primeira sede do Paulistano, que tinha em Antonio Prado Júnior sua figura proeminente. Ali, foram disputadas quase todas as partidas do Paulistano nos primeiros campeonatos paulistas entre 1902 e 1915, e, mesmo com a inauguração do Parque Antarctica, em 1902, recebeu as principais partidas amistosas do chamado futebol oficial da cidade, que

\footnotetext{
${ }^{24}$ REALI, Ebe. Brás, Pinheiro, Jardins. Três bairros, três mundos. São Paulo, Edusp, 1982. Pág. 179. A autora não informa por quanto tempo ou quando esse valor foi cobrado. É preciso salientar que, entre 1902 e 1915, o Velódromo era considerado o principal campo da cidade, o local onde os times disputavam partidas contra equipes visitantes, considerado o campo oficial da LPF ou da APEA.

${ }^{25}$ REIS FILHO, Nestor Goulart. Futebol e os velódromos. Jornal da Tarde, 09.06.1990, Pág. 6.

${ }^{26}$ Club Athlético Paulistano. 18. ${ }^{\circ}$ Anniversário. O Estado de S. Paulo. 19/12/1918. Pág. 5.

${ }^{27}$ Existem divergências em relação a essas datas. Uso como referência os dados de Thomaz Mazzoni, em História do Futebol no Brasil, e reiterados pelos documentos encontrados no IEB, na Coleção Caio Prado Jr, mas em artigo publicado no Jornal da Tarde, em 09/06/1990, Nestor Goulart Reis Filho apresenta outras informações sobre a inauguração do Velódromo, como ocorrida em 1892, e a primeira partida de futebol em 1896.
} 
envolviam times visitantes de outras cidades brasileiras ou mesmo do exterior, até seu desaparecimento em 1915.

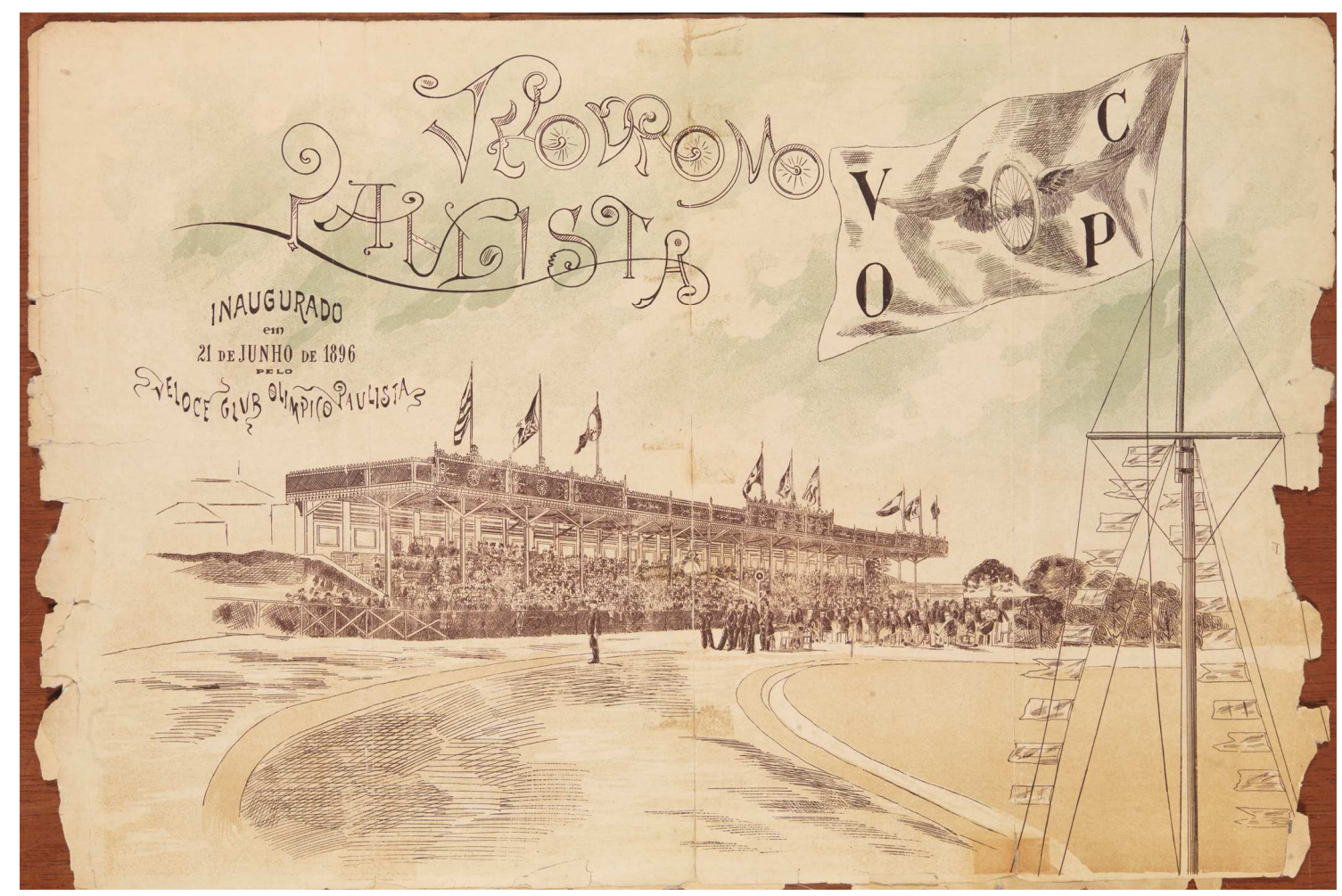

1. Ilustração na revista A Bohemia - SP $1^{\circ}$ Anno - Julho n5 - Diretor José Piza (Coleção Caio Prado Jr. - IEB - USP)

Por se tratar de espaço improvisado para a prática do futebol, com o crescimento do esporte, sua utilização foi ficando comprometida, pois as críticas quanto às dimensões do campo eram constantes entre os visitantes. Além disso, os valores de locação do Velódromo Paulista cobrados pelo Paulistano eram altos, o que foi um dos fatores que deflagraram o conflito entre os diversos times membros da Liga Paulista de Futebol, em 1913, marcando a primeira ruptura do futebol paulista. Naquela ocasião, o Germânia, que locava o Parque Antarctica da Cia. Antarctica Paulista, propôs à Liga Paulista de Futebol a utilização de seu campo por $200 \$ 000$ por mês, preço cobrado pelo Paulistano por cada partida disputada no Velódromo. Por tal motivo, a LPF acolheu a proposta do Germânia, situação que não foi aceita pelo Paulistano, que preferiu romper com a Liga e criar uma nova Associação para o futebol em São Paulo. ${ }^{28}$

\footnotetext{
${ }^{28}$ As diversas rupturas ocorridas entre os times daquele período serão devidamente tratadas em capítulo específico mais adiante.
} 
O crescimento da cidade ultrapassou os limites do Velódromo e a nova Associação, chamada Associação Paulista dos Esportes Atléticos - APEA, grafada naquela época como Associação Paulista de Sports Athléticos - APSA, foi obrigada a utilizar os espaços da nova área que a Prefeitura destinara para a construção de praças de esportes na cidade, a Chácara da Floresta ou o campo da nova sede do Paulistano, nos Jardins. Depois de desapropriado, em 1915, o Velódromo foi demolido, seu terreno foi loteado para a construção de casas, através de uma rua ali aberta, chamada Florisbela, atual Nestor Pestana.

Desde 1902, o Parque Antarctica funcionava como um dos principais centros de lazer da cidade. Localizava-se em área distante do centro de São Paulo, que concentrava parcela significativa das novas indústrias da cidade, construído pela Cia. Antarctica Paulista e possuía área de 150 mil metros quadrados com jardins planejados, passeios, lagos, espaços para piquenique, parques infantis, pistas de atletismo, quadras de tênis e campos de futebol, um dos quais era utilizado pelo Sport Club Germânia. ${ }^{29} \mathrm{O}$ "Parque da Antarctica Paulista" era um local que podia ser comparado com o Parque do Ibirapuera, a principal área de lazer da cidade. ${ }^{30} \mathrm{Nele}$, foi disputada a primeira partida da história dos campeonatos paulistas, em três de maio de 1902, com vitória do Mackenzie sobre o Germânia. ${ }^{31}$

Em 1916, os dois campos de futebol existentes no Parque Antarctica foram arrendados pelo Germânia por 350\$000 até 1921, mais o pagamento de indenização de $35 \$ 000$ mensais para o antigo locatário, até 1918. O contrato permitia ao clube alugar o espaço para outros usuários desde que a finalidade fosse exclusivamente esportiva, caso do Palestra Itália, ${ }^{32}$ clube fundado em 1914 e recém-admitido na APEA, e que, com a ajuda das Indústrias Matarazzo e seus funcionários, passou a mandar seus jogos no Parque Antarctica, em 1916, por meio de locação do espaço. ${ }^{33}$ Em 1920, depois da

\footnotetext{
${ }^{29}$ MAZZONI, Thomáz. História do Futebol no Brasil. Op. Cit. Pág. 30.

${ }^{30} \mathrm{Cf}$. http://www.palmeiras.com.br/clube/estadio.asp. Os dados da extensão do terreno são conflitantes, pois, no mesmo sítio existe a informação de que o terreno tinha $300 \mathrm{mil} \mathrm{m}$.

${ }^{31}$ MAZZONI, Thomáz. Idem, Ibidem. O resultado da partida, segundo o autor foi Mackenzie 2X1 Germânia.

${ }^{32}$ MORAES, José Geraldo Vinci de. Metrópole em Sinfonia. História, Cultura e Música Popular em São Paulo nos anos 1930. Tese de Doutorado em História Social. FFLCH - USP, São Paulo, 1997. Pág. 242. Consta a informação de que o Palestra Itália alocava os campos do Parque Antarctica desde 1916.

${ }^{33}$ MAZZONI, Thomaz; PERUZZI, Milton; GUIMARÃES, Tyrso Fernandes. No tempo do "Palestra é Palestra". (In): Álbum Comemorativo Jubileu de Ouro da Sociedade Esportiva Palmeiras. Segundo o
} 
ruptura do contrato entre o Germânia e a Cia. Antarctica Paulista, ${ }^{34}$ o Palestra Itália comprou o Parque Antarctica por 500 contos de réis, mobilizando parcela ponderável da comunidade italiana em São Paulo. A negociação gerou espanto entre os habitantes de São Paulo e os membros das demais equipes, dadas às dimensões e valores envolvidos. O Palestra Itália deu 250 contos de réis de entrada e mais duas letras hipotecárias, parcelando o restante em duas vezes, com vencimento para 1921 e $1922 .{ }^{35}$ O pagamento da última parcela não foi possível, razão pela qual o clube teve que vender $60 \mathrm{mil} \mathrm{m}^{2}$ à família Matarazzo, dos $150 \mathrm{mil} \mathrm{m}^{2}$ adquiridos da Cia. Antarctica.

Desde então, a Sociedade Esportiva Palestra Itália realizou melhorias para transformar a tradicional praça de esportes em estádio. O primeiro projeto de estádio foi apresentado ainda em setembro de $1920 .{ }^{36}$ Mas, por toda a década seguinte, o Parque Antarctica continuou funcionando como um campo de futebol no qual as arquibancadas eram improvisadas nos barrancos existentes nas laterais do campo e os torcedores se mesclavam com as árvores. Em março de 1929, o clube apresentou o projeto de remodelação do Parque Antarctica que incluía uma sede social nova, a construção de um estádio com iluminação noturna, piscina, quadras de tênis e seção hípica ${ }^{37}$.

O estádio ocuparia a centralidade do terreno e seria o mais grandioso edifício de toda a instalação, tendo a forma característica, que, pela A Gazeta Esportiva, era adotada em outros estádios construídos na época: um retângulo acabado com dois semicírculos nas extremidades, medindo o eixo maior 270 metros de comprimento e o eixo menor 160 metros. A ideia era utilizar o campo para o jogo de futebol e de rúgbi e as laterais como pista de corrida. As arquibancadas seriam divididas em duas partes:

autor, as relações do clube com as Indústrias Matarazzo e seus funcionários se aprofundaram a partir de 1916.

${ }^{34}$ Os motivos da ruptura apurados são diversos e muitas vezes conflitantes. Em livro de 1968, Mário Graco Ribas afirma que a atuação do Conde Matarazzo foi fundamental para a ruptura do contrato e a venda posterior para o time ítalo-brasileiro. Alguns depoimentos informais de sócios do Palmeiras afirmam que parte do pagamento para a Cia. Antarctica Paulista se deu com o terreno na Mooca que pertencia à família Matarazzo e que passou a sediar a fábrica da Antarctica em São Paulo. A situação financeira do Germânia foi afetada pela Primeira Guerra Mundial, quando a comunidade alemã da cidade sentiu os efeitos econômicos do conflito, segundo depoimento de Oscar Friedenreich, cf. RIBAS, Mário Graco. História do Esporte Clube Pinheiros. São Paulo, ECP, 1968. Pág. 25. O contrato de rescisão, de 1919, também aponta o atraso do pagamento do aluguel pelo Germânia. Acervo do Centro Pró-Memória Hans Nobiling do Esporte Clube Pinheiros.

${ }^{35} \mathrm{Cf}$. http://www.palmeiras.com.br/hs_arena/index.htm.

${ }^{36}$ Il progetto del dott. I. A. Pereira Queiroz. Fanfulla. 05/09/1920. Pág. 05.

${ }^{37}$ Características do estádio projetado pelo Palestra. A Gazeta Esportiva, 11 de março de 1929. Pág. 7. 
uma para o público geral, com capacidade para 24 mil pessoas; outra reservada, por sua vez dividida em três corpos: central de honra, para 600 pessoas, e laterais, para 5.400 pessoas em cada. Ainda seria possível acomodar mais dez mil pessoas nas sacadas superiores e inferiores das arquibancadas, totalizando 45.500 pessoas. $^{38}$

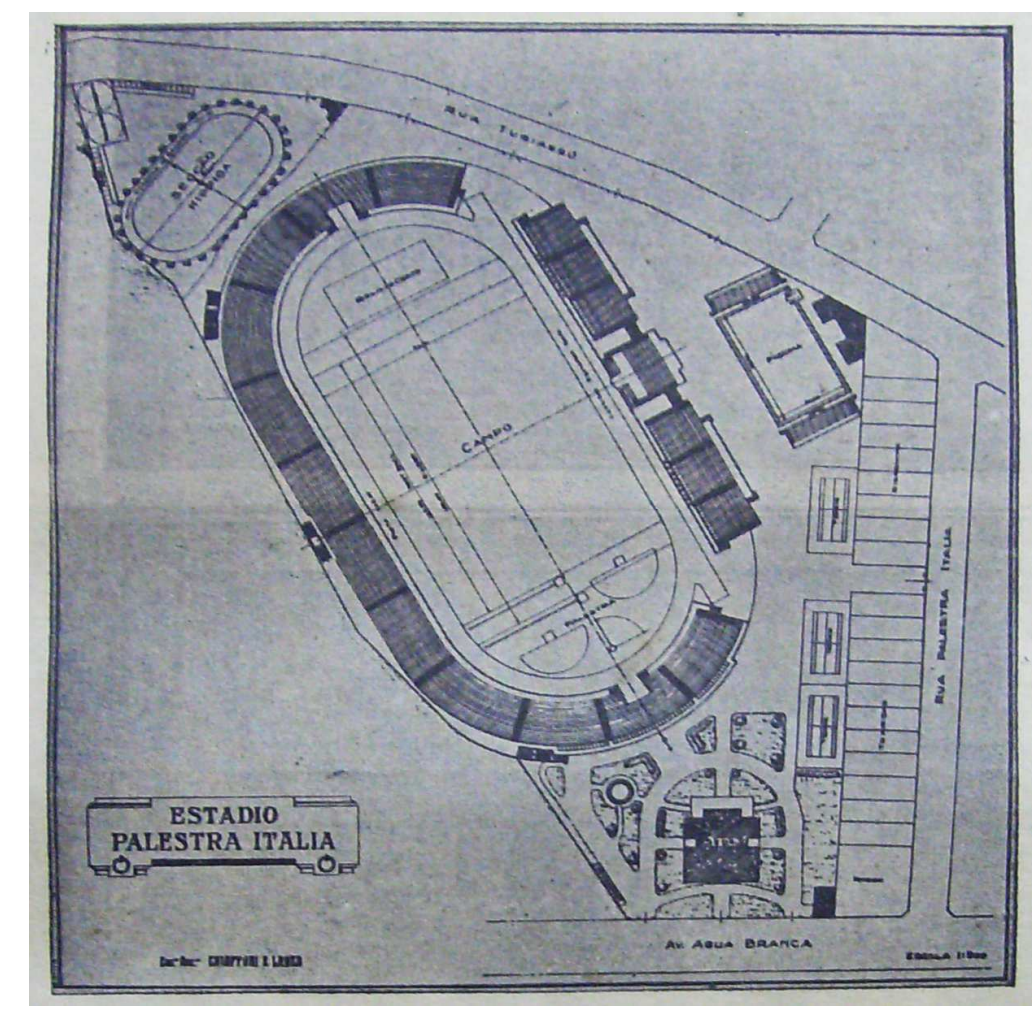

2. Planta apresentada em 1929 pelo Palestra Itália para a construção de um estádio.

Nos anos subsequentes, o projeto foi levado adiante só parcialmente, por falta de recursos, com a inauguração de parte das arquibancadas em $1933 .{ }^{39}$ A construção do estádio palestrino se arrastou, com o projeto original sendo alterado e realizado em formato de ferradura semelhante ao do Estádio Municipal do Pacaembu, com capacidade um pouco menor, para 32 mil torcedores. ${ }^{40}$

\footnotetext{
${ }^{38}$ Idem, Ibidem.

${ }^{39}$ FERREIRA, João Fernando. A construção do Pacaembu. São Paulo, Paz e Terra, 2008. Pág. 50.

${ }^{40}$ Ainda assim, até meados da década de 1950, o Parque Antarctica era considerado a melhor praça de esportes particular da cidade. Apenas em 1958, a sede do Palmeiras teve seu nome alterado para Stadium Palestra Itália, algo desejado pelos palestrinos desde a compra do Parque Antarctica. Cabe reiterar que nos anos 1960, o gramado foi elevado para evitar problemas de enchente que eram comuns na região. Desde então, o Estádio Palestra Itália foi o único da cidade com essa característica, denominada de jardins suspensos pelos simpatizantes da equipe.
} 
Velódromo Paulista e Parque Antarctica se transformaram em referências nos anos subsequentes para a construção das diversas praças desportivas que se espalharam pela cidade nos primeiros decênios do século XX. A construção do Parque da Floresta pela Prefeitura, a aquisição do Parque São Jorge pelo Sport Club Corinthians Paulista e as novas sedes do Paulistano, no Jardim América, e do Germânia, no Itaim, seguem o padrão referido das duas praças. O processo de urbanização do início do século XX ainda não elimina do horizonte da cidade os vastos espaços verdes utilizados para as práticas esportivas e outras formas de lazer. ${ }^{41}$

Nos seis casos acima citados, falamos de praças de esportes, grandes áreas verdes utilizadas para a prática de esportes, nas quais as arquibancadas no entorno dos campos de futebol, quando existiam, eram improvisadas, tubulares, misturadas às árvores, sem qualquer espaço específico para jornalistas ou autoridades públicas, separadas do gramado por uma pequena cerca. Tais praças se converteram nas atuais sedes dos clubes, sem se transformarem em estádios por falta de espaço ou dinheiro (como no caso de Corinthians), falta de interesse (como nos casos do Paulistano e do Germânia) ou desapareceram com o crescimento da cidade (casos do Parque da Floresta e do Velódromo Paulista).

Alguns clubes chegaram a manter diversas praças de esportes e sedes espalhadas pela cidade, na década de 1910, como o Germânia, que mandava seus jogos de futebol no Parque Antarctica, mantinha sua sede de esportes aquáticos na Chácara da Floresta e sua sede social no centro de São Paulo. ${ }^{42}$ O Paulistano e a A.A. das Palmeiras mandavam seus jogos de futebol na Chácara da Floresta, mas tinham sedes sociais nos bairros Jardim América e Santa Cecília. Outros clubes de futebol conseguiram as próprias praças desportivas no decorrer do século XX, como o Ypiranga, a Portuguesa, o Juventus e o Nacional. Com o passar dos anos e o aumento dos aluguéis no centro da cidade, decorrentes da especulação imobiliária gerada pela reurbanização da área central

\footnotetext{
${ }^{41} \mathrm{Na}$ época, as pessoas passavam o dia nas praças desportivas. Saíam cedo de casa nos dias de folga e, junto ao gramado do campo de futebol, costumavam realizar piqueniques. Não era raro o ingresso de caminhões nas praças, inclusive em dia de jogos, saindo apenas com o término das partidas. Por volta de 1930, ainda eram correntes, n' A Gazeta Esportiva, anúncios das diretorias dos times informando que não seriam autorizadas as presenças de caminhões e carros nas áreas destinadas ao público.

${ }^{42}$ Segundo a Revista Comemorativa do Cinquentenário do Esporte Clube Pinheiros, a sede social do clube teve diversos endereços até se estabelecer definitivamente no atual endereço, na década de 1920.
} 
realizada nas gestões Antonio Prado (1899-1910) ${ }^{43}$ e Raymundo Duprat (1911-1913), os clubes passaram a juntar todas as práticas esportivas e sedes em um só espaço, dando preferência a áreas da cidade que permitiam a prática de diversos esportes, como as áreas alagadiças e pantanosas das várzeas, que além de possuírem preços mais convidativos no processo de especulação imobiliária, permitiam o desenvolvimento de modalidades aquáticas sem grandes investimentos em piscinas.

Logo após o desaparecimento do Velódromo, o Paulistano comprou o terreno de uma nova sede no Jardim América, que pertencia à Cia. City, por $150.000 \$ 000$ a serem pagos em 240 prestações de $1.074 \$ 650$, dinheiro arrecado por meio de campanhas entre os sócios. Na sequência, um terreno vizinho foi adquirido de um proprietário particular por 20.000\$000. A área do clube passou a ter $27 \mathrm{mil} \mathrm{m}^{2}$. Quando o clube abandonou o futebol oficial, em 1929, a área em que ficava o campo principal destinado ao futebol foi transformada numa larga área arborizada. ${ }^{44}$

O Germânia adquiriu sua praça desportiva em 1920, na Chácara do Itaim; o terreno possuía cem mil $\mathrm{m}^{2}$ e custou $80.000 \$ 000$. Posteriormente, a área do clube foi ampliada com a aquisição de cerca de 70 mil m² entre os anos 1930 e 1950, após a retificação do rio Pinheiros. O Corinthians adquiriu sua sede atual, o Parque São Jorge, em 1928. Pertencia, até então, ao Esporte Clube Sírio e custou $28.000 \$ 000 .{ }^{45}$ Sua localização na zona leste de São Paulo, no bairro do Tatuapé, região fabril da cidade, reforçou ainda mais a identidade do clube com o operariado.

Diante das tentativas de restringir a prática do futebol, impostas pela Prefeitura, o espaço mais utilizado pelos novos times e pelos jogadores pobres para a prática do esporte era a várzea do Carmo. Tratava-se de lugar amplo e plano, que ficava fora do perímetro central da cidade, uma área que começava a ser ocupada pelos operários imigrantes, que inundava na época das chuvas e era utilizada pelas lavadeiras, mas que se transformava em um espaço ideal para o futebol, distante do controle da Prefeitura.

\footnotetext{
${ }^{43}$ ROLNIK, R. A cidade e a lei. Legislação, política urbana e territórios na cidade de São Paulo. Pág. 25. A autora informa que, desde 1900, a hipoteca de imóveis urbanos passou a ser aceita pelos bancos como garantia de empréstimos a fazendeiros de café. E que, desde 1902, o investimento em imóveis nas áreas urbanas de São Paulo representava uma alternativa aos altos e baixos da economia cafeeira.

${ }^{44}$ REALI, Ebe. Op. Cit. Págs. 181 e 189.

${ }^{45}$ Mosaicos Alvinegros. Campeão dos Centenários. Álbum celebrativo da Revista do Corinthians de 1965. Cf. http://www.corinthians.com.br /2008/clube/default.asp?categoria=Memorial.
} 
Pela documentação consultada, em 1902, ano do primeiro Campeonato Paulista, surgiram as primeiras equipes que disputavam futebol na várzea do Carmo. Quase sempre, eram times formados por jovens operários, muitas vezes crianças, que utilizavam as horas vagas para jogar futebol. Nas palavras de Mazzoni, o pequeno futebol é tão velho quanto o outro ${ }^{46}$. A canalização do rio Tamanduateí a partir de 1914 impediu a disputa de partidas na área que deu origem ao atual Parque D. Pedro, empurrou os times formados pelos habitantes pobres que atuavam naqueles campos para outras zonas de várzea por toda a cidade, incluindo outras do próprio Tamanduateí. ${ }^{47}$ Assim, as várzeas da cidade foram tomadas por campos e times de futebol, que só desapareceram com a transformação das várzeas dos rios em grandes avenidas, a partir da segunda metade do século XX. Por toda a cidade, onde houvesse um riacho, córrego ou rio, havia um campo de futebol.

A Prefeitura, no entanto, não desistia de tentar regulamentar a prática do futebol - e de outros esportes também - e mediante Lei n. ${ }^{\circ} 1.486$, de 01/12/1911, o Prefeito Raymundo Duprat recebeu autorização para adquirir uma área que se prestasse à instalação dos equipamentos necessários às práticas esportivas destinadas à educação física. $^{48}$

Em 1912, a área escolhida pela Prefeitura para as práticas esportivas em São Paulo foi a Chácara da Floresta, que ficava à margem esquerda do rio Tietê, ${ }^{49}$ em região bem distante do perímetro urbano e que atendia ao artigo da lei que determinava a

\footnotetext{
${ }^{46}$ MAZZONI, Thomaz. Op. Cit. Pág. 77.

47 TOLEDO, Benedito Lima de. São Paulo: Três cidades em um século. São Paulo, Cosac \& Naify/Livraria Duas Cidades, 2004. Pág. 124. A criação do Parque D. Pedro foi uma das muitas contribuições urbanísticas trazidas pelo arquiteto Joseph Antoine Bouvard por meio de relatório entregue à Prefeitura, em 1911.

${ }^{48}$ Lei $n .^{\circ}$ 1.486, de 01/12/1911. Art.1. ${ }^{\circ}$ - Fica a Prefeitura autorizada a adquirir, por compra ou pelos meios que julgue conveniente, "ad-referendum" da Camara, uma área de terreno nesta capital, que se preste á installação do necessario, a exercícios sportivos destinados á educação physica da mocidade. Art.2. - Será feita uma secção para a natação, composta de um grande lago e dependencias que forem necessarias. Art.3. ${ }^{\circ}$ - A prefeitura submetterá ao juizo da Camara, em tempo opportuno, um regulamento concernente aos alludidos exercicios, dos quaes se excluirá toda idea de jogo. Art.4. ${ }^{\circ}$ - Para a execução desta lei, a Prefeitura fará as necessarias operações de credito. Relatório de Governo enviado à Câmara Municipal pelo Senhor Prefeito Raimundo Duprat, em 1915. São Paulo, SOR/BMMA.

49 Lei $n^{\circ}$ 1.507, de 21 de março de 1912. Art.1. ${ }^{\circ}$ - Fica o Prefeito autorizado a adquirir a chacara denominada "Floresta", á margem esquerda do rio Tietê, com todas as suas bemfeitorias, pelo preço de trezentos e cincoenta contos de réis (350:000\$000). Art.2. ${ }^{\circ}$ - As despesas correrão pela verba competente do orçamento vigente, podendo, além disso, caso seja necessario, fazer emissão de letras no valor nominal, ao par, de cem mil réis (100\$000), a juros de seis por cento (6\%). Relatório de Governo enviado à Câmara Municipal pelo Senhor Prefeito Raimundo Duprat, em 1915. SOR/BMMA.
} 
criação de uma área destinada à prática da natação. A escolha da área reforçava a tendência de ocupação das várzeas pelos campos de futebol. Em 1913, pela Lei n. ${ }^{\circ}$ 1.681, a Prefeitura declarou de utilidade pública diversos prédios que deveriam ser demolidos para o alargamento da Avenida Tiradentes assim como os terrenos anexos à antiga Chácara, que serviriam para a formação do Parque da Floresta.

Desde o final do século XIX, as margens do rio Tietê nas proximidades da Ponte Grande eram utilizadas pelos clubes de remo, que a partir do início do século, com a popularização do futebol, passaram a alugar suas sedes para que alguns times do chamado futebol oficial pudessem montar seus campos, caso da Associação Athlética das Palmeiras e do Esporte Clube Internacional. Quase sempre, os terrenos ocupados pertenciam à municipalidade, ${ }^{50}$ os clubes deles se apossavam e entravam em acordo com a Prefeitura para adquirir a concessão que chegava a durar 100 anos ou pagavam aluguel. ${ }^{51}$ Com a criação do Parque da Floresta, boa parte dos clubes da cidade migrou para lá, já que a Prefeitura concedia o espaço. O Corinthians, por exemplo, inaugurou sua primeira praça de esportes ali, em 1918, depois que os próprios jogadores trabalharam na construção do gramado. ${ }^{52}$ As arquibancadas do Velódromo Paulista foram transferidas para lá em 1916 e o Club Athlético Paulistano e A.A. das Palmeiras mandaram seus jogos até desistirem do futebol. ${ }^{53}$

Em meados de $1906,{ }^{54}$ partidas de futebol já eram disputadas na Chácara da Floresta, que, com a iniciativa da Prefeitura de 1912, transformou-se no espaço aglutinador de diversos clubes esportivos, como o Club Espéria (fundado em 1899 por jovens italianos), Clube de Regatas Tietê (fundado em 1907), o Club São Paulo de Regatas, a Associação Athlética São Paulo (fundada em 1914 para a prática da natação e do remo, e que foi o primeiro clube a construir uma piscina na cidade, no início dos anos 1930), que se dedicavam aos esportes aquáticos, e em local de concentração dos

\footnotetext{
${ }^{50}$ Informação colhida dentro da A.A. São Paulo, em 2005. O dirigente que nos atendeu explicou como os clubes procediam e afirmou ser a Atlética o único clube a possuir sede própria dentre os clubes remanescentes naquela região e que os demais enfrentavam dificuldades com a Prefeitura para renovar a concessão.

${ }^{51}$ ALMEIDA, Antonio de. Revista do Corinthians $n .{ }^{\circ}$ 112. Fevereiro de 1959. Na coluna Falando a Verdade, o cronista afirma que o Corinthians pagava aluguel para a prefeitura para poder manter sua praça de esportes na Chácara da Floresta. Pág.7.

${ }^{52}$ MAZZONI, Thomáz. Op. Cit. Pág. 125.

${ }^{53}$ MAZZONI, Thomáz. Op. Cit. Pág. 108.

${ }^{54}$ MAZZONI, Thomáz. Op. Cit. Pág. 61.
} 
campos de futebol de times como o Sport Club Internacional, ${ }^{55}$ o Sport Club Corinthians Paulista e a Associação Athlética das Palmeiras (fundada em 1905, no bairro de Santa Cecília), além de berço do São Paulo Futebol Clube, surgido entre 1930 e 1935. Os times de futebol mantinham suas sedes sociais na região central da cidade, em escritórios alugados.

Com o desenvolvimento urbano acelerado, a região da Chácara da Floresta deixou de ser área periférica; foi quando nas gestões de Fábio Prado e Francisco Prestes Maia, se construiu a nova Ponte Grande, no decorrer dos anos 1930, ligando uma margem à outra e promovendo a retificação do rio para a futura construção da Avenida Marginal, sendo incorporada ao bairro do Canindé. Entre 1920 e 1950, algumas equipes migraram da Chácara da Floresta e construíram sedes próprias, caso do Corinthians, que, em 1928, adquiriu a Fazendinha na Rua São Jorge, na Zona Leste. Apenas na década de 1950, o São Paulo migraria do Canindé para o Morumbi, local em que construiria o que era o maior estádio particular do mundo, ${ }^{56}$ inaugurado no final dos anos 1960.

Podemos definir os estádios de futebol como lugares de memória monumentais, funcionais e simbólicos, ${ }^{57}$ pois, além da arquitetura, servem de espaço para as celebrações ritualísticas ou futebolísticas e para a narração da memória das associações desportivas que denominamos clubes. As primeiras sugestões sobre a construção de um grande estádio municipal para a cidade aparecem na documentação oficial desde 1919, visando às celebrações do I Centenário da Independência. Naquela ocasião, a Prefeitura instituiu o campeonato oficial da cidade, que deveria ocorrer em 1922, com outros campeonatos municipais ocorrendo a cada cinco anos. As partidas deveriam ser disputadas em um estádio municipal a ser construído, podendo dele participar um

\footnotetext{
55 Segundo a Lei n. $^{\circ}$ 3.183, de 19/05/1928, o campo do Sport Club Internacional ficava em terreno municipal junto ao Club Espéria, na margem direita do rio Tietê, provavelmente onde hoje está o Parque do Anhembi. Thomaz Mazzoni afirma que o Germânia e o Internacional começaram nas chácaras do Bom Retiro, migrando posteriormente para outras regiões (o Germânia alugou primeiro o Parque Antarctica e depois se estabeleceu às margens do rio Pinheiros, no bairro do Itaim).

${ }^{56}$ O Estádio Cícero Pompeu de Toledo, nome oficial do Estádio do Morumbi, foi considerado o maior estádio particular do mundo na década de 1970, quando chegou a receber públicos de até 140 mil espectadores. Atualmente, sua capacidade está reduzida a cerca de 70 mil espectadores.

${ }^{57}$ LE GOFF, Jacques. Op. Cit. Pág. 467. Segundo o autor, a história dita "nova" fermenta a partir do estudo dos lugares da memória coletiva. Na sequência, apresenta subdivisões do termo, como lugares topográficos (arquivos, bibliotecas e museus), lugares monumentais (cemitérios ou arquiteturas), lugares simbólicos (comemorações, peregrinações, aniversários ou os emblemas) e lugares funcionais (manuais, autobiografias e associações).
} 
número limitado de times, sendo selecionadas as equipes campeãs de diversas cidades brasileiras. $^{58}$

No decorrer das décadas de 1920 e 1930, a construção não foi possível em decorrência das diversas rupturas e brigas entre os clubes. Ao término das disputas, times tradicionais da cidade fecharam os respectivos departamentos de futebol ou faliram: o Club Athlético Paulistano fechou seu departamento de futebol em 1929, a Associação Athlética das Palmeiras vivia situação pré-falimentar no mesmo ano e o Esporte Clube Internacional foi incorporado ao São Paulo da Floresta, em 1933. ${ }^{59}$

A partir de 1930, a pacificação parcial entre os clubes não foi suficiente para permitir a construção do estádio, pois a ascensão de Getúlio Vargas, a crise econômica decorrente da bancarrota da economia cafeeira e a instabilidade política do período não permitiam tal empreendimento. Em apenas quatro anos (1930-1934), a cidade contou com 13 prefeitos que não tiveram tempo suficiente no comando da cidade para implementar algum tipo de política administrativa e urbana. Apenas com a ascensão de Fábio Prado (1934-1938) e a realização de uma ampla reforma administrativa, a situação caótica foi contornada, permitindo o início das obras do Estádio no ano de 1937, em terreno doado para tal fim pela Cia. City. ${ }^{60}$

A construção do estádio fazia parte de um projeto amplo de grandes obras, como a Biblioteca Municipal, o Parque do Ibirapuera e a aplicação do Plano de Avenidas para a cidade de São Paulo, desenvolvido por Francisco Prestes Maia na gestão de José Pires do Rio (1926-1930), fenômeno definido por José Geraldo da Vinci de Moraes como

${ }^{58}$ Lei n. $^{\circ}$ 2.201, de 01/07/1919. Art.1. ${ }^{\circ}$ - Fica creado o campeonato de foot-ball da cidade de S. Paulo. Art.2. ${ }^{\circ}$ - A victoria final será disputada em acções successivas, que deverão desenvolver-se nesta cidade, no Stadium Municipal, em épocas determinadas pelo prefeito. Art.3. ${ }^{\circ}$ - Os campos adversários serão defendidos por guarnições de escol, formadas unicamente de campeões brasileiros natos, membros de associações de foot-ball deste e de outros municípios do Brasil. Paragrapho único - Será limitado o numero de concorrentes ao campeonato. Art. 4. ${ }^{\circ}$ - O primeiro campeonato se decidirá em 1922 , e os outros serão disputados em cinco annos. Art.5. ${ }^{\circ}$ A guarnição vencedora receberá um premio que perpetuará a victoria obtida. Art.6. ${ }^{\circ}$ - Os campeões paulistanos ostentarão no braço esquerdo o brazão da cidade. Art..$^{\circ}$ - Com a execução desta lei, o prefeito poderá despender até a quantia de cinco contos de réis, que será consignada na lei orçamentária, no primeiro anno de cada campeonato. Relatório de Governo enviado à Câmara Municipal pelo Senhor Prefeito Washington Luis, em 1920. SOR/BMMA

${ }^{59}$ Retornando... Augusto Castro Leite, 2. ${ }^{\circ}$ thesoureiro da A.A. Palmeiras, volta á atividade esportiva - O que s.s. nos contou sobre o tradicional núcleo da Floresta. A Gazeta Esportiva, 24/11/1929. Pág.15.

${ }^{60}$ MAZZONI, Thomáz. Op. Cit. Pág. 289. Segundo o autor, o terreno foi doado ao Governo do Estado em 1920, já com a intenção de construir um grande estádio. 
febre urbanizadora que criou graves consequências para a cidade, ${ }^{61}$ como a construção do mito da São Paulo "que não para e não pode parar" e a transformação estrutural da São Paulo do café na capital da indústria nacional. ${ }^{62}$

Quando assumiu a Prefeitura, em 1938, Francisco Prestes Maia modificou o projeto original do Estádio Municipal, ampliando-o para criar, além do Estádio, uma completa praça de esportes com piscina, quadras e ginásio, inspirada na monumentalidade da arquitetura alemã. Tal iniciativa se devia ao desempenho da Seleção Brasileira na Copa do Mundo de Futebol daquele ano, que aumentara o entusiasmo da população com o futebol.

Construído no Estado-Novo, ${ }^{63}$ o Estádio Municipal do Pacaembu apresenta os elementos descritos por Mascarenhas e Gaffney: objeto geográfico disseminado por regime ditatorial que celebrava o prestígio alcançado pelo futebol junto à sociedade paulistana (e brasileira também, pois se tratava do maior estádio brasileiro daquele período), de imensa visibilidade e conotação simbólica, capaz de mobilizar a sociedade inteira. Não por acaso, diversas esferas do poder público em São Paulo participaram de sua construção e estiveram envolvidas na organização da festa de inauguração. ${ }^{64}$

A programação de inauguração se estendeu por duas semanas, a partir do dia 27 de abril de 1940. Nesse dia, o prefeito Prestes Maia, o interventor federal de São Paulo Adhemar de Barros, o presidente Getúlio Vargas, os interventores de Minas Gerais e do Rio de Janeiro, além de outras autoridades da época, assistiram ao grande desfile de atletas de diversas cidades de São Paulo e do exterior. O espírito disciplinar era marcante, pois a organização interferiu até nos uniformes utilizados pelos clubes durante o desfile e foi proibida a prática de esportes em outros espaços da cidade na semana de inauguração do Estádio Municipal. ${ }^{65}$

\footnotetext{
${ }^{61}$ MORAES, José Geraldo Vinci de. Metrópole em Sinfonia. História, Cultura e Música Popular em São Paulo nos anos 1930. Tese de Doutorado apresentada ao Dep. de História da FFLCH - USP, São Paulo, 1997. Pág. 181.

${ }^{62}$ MORAES, José Geraldo Vinci de. Op. Cit. Pág. 104. ROLNIK, R. Op. Cit. Pág. 192.

${ }^{63}$ FERREIRA, João Fernando. A construção do Pacaembu. Pág. 65. Segundo o autor, quando Prestes Maia assumiu a Prefeitura, a obra ainda estava no começo, sendo alterada pelo próprio prefeito, em 1938. Ainda segundo o autor, o projeto original pertencia à Domenico Pacheco, arquiteto do escritório Ramos de Azevedo. A alteração do projeto contou com a ajuda dos arquitetos do mesmo escritório.

${ }^{64}$ FERREIRA, João Fernando. Op. Cit. Pág. 77.

${ }^{65}$ FERREIRA, João Fernando. Op. Cit. Págs. 77 e 78. Em nota apresentada no jornal $O$ Estado de S.Paulo por ocasião da inauguração, os organizadores ressaltavam que, para maior uniformidade dos desfiles, todos os componentes dos clubes deveriam desfilar com sapatos brancos ou Keds da mesma cor,
} 
Na programação relativa ao futebol, duas partidas foram marcadas com os dois principais times da cidade: Palestra Itália X Coritiba, no dia 28 de abril, e Corinthians X Atlético Mineiro, no dia seguinte. Os vitoriosos disputariam uma outra partida no fim de semana seguinte. Segundo Mazzoni, nesse ano foi realizado o primeiro jogo de futebol feminino no Estádio, em uma preliminar do jogo entre o São Paulo e o Flamengo, sem despertar o interesse do público pela modalidade. ${ }^{66}$

Construído com técnica desenvolvida no Brasil, que combinava cimento e ferro, o Estádio Municipal se transformou "na afirmação da capacidade e esforço criador do regime (Estado Novo), na execução do seu programa de realizações. ${ }^{67, "} \mathrm{O}$ governo Vargas se esforçava naquele contexto para reformular as diretrizes econômicas do País, e São Paulo se mostrava a região mais adequada para assumir o papel de baluarte do desenvolvimento industrial planejado pelas autoridades públicas dentro do programa de realizações descrito pelo próprio presidente.

Paradoxalmente, o processo de transformações aceleradas desse período permitiu a construção de um referencial mítico sobre o passado da cidade como um suposto passado bucólico, de uma cidade que era mais humana e menos violenta, sensações muito fortes no discurso dos memorialistas daquele período diante das dimensões gigantescas que a cidade começava a tomar por meio das grandes avenidas e projetos viários, pelo número de indústrias, tamanho da população - que nessa época, já passara do primeiro milhão - ou pelo novo estádio que se erguia nas cercanias do bairro do Pacaembu.

Projetos como o Plano de Avenidas e a realização de diversas obras como a Avenida Nove de Julho e o Estádio Municipal apresentavam para a municipalidade as novas formas de ocupação das várzeas da cidade intencionadas pela Prefeitura, com os rios devidamente canalizados e ocupados pelas grandes avenidas, soluções que foram largamente adotadas na segunda metade do século XX. O processo, testemunhado

camisas para dentro dos calções, respeitando-se os uniformes dos clubes de origem dos atletas. Na página 77, o autor apresenta a relação completa dos eventos esportivos que ocorreram nessas semanas.

${ }^{66}$ MAZZONI, Thomáz. Op. Cit. Pág. 289. O Palestra Itália venceu por $6 \mathrm{X} 2$ e o Corinthians por $4 \mathrm{X} 2$. O primeiro gol no Estádio foi marcado por Zequinha, atacante do Coritiba. Na disputa entre Palestra Itália e Corinthians, os palestrinos venceram por $2 \mathrm{X} 1$.

${ }^{67}$ FERREIRA, João Fernando. Op. Cit. Pág. 86. Discurso do presidente Getúlio Vargas por ocasião da inauguração do Estádio, reproduzido no livro citado. 
pelos habitantes da cidade e descrito por Raquel Glezer, ${ }^{68}$ de grandes intervenções urbanas desse período começou ainda no final dos anos 1930 e se consolidou em meados dos 1970, representando um duro golpe ao chamado futebol varzeano. Nesse período, todo o leito do rio Tamanduateí foi canalizado, boa parte foi transformada em pista para automóveis e sumiu da paisagem urbana; as margens dos rios Tietê e Pinheiros viraram grandes avenidas expressas; outras várzeas viraram avenidas. Os terrenos vazios desapareceram junto com os campos servindo de justificativa para muitos paulistanos afirmarem que o futebol de várzea corria o risco de morrer.

A construção do Estádio Municipal apontava, também, para as maneiras de torcer que predominariam na segunda metade do século XX, pela organização das torcidas, com coreografias e cantos. Se na inauguração do Estádio, a praça em frente ao estádio foi utilizada para o piquenique, pouco a pouco, o hábito desapareceu sendo suplantado pelas carrocinhas e barracas que vendem sanduíches - sempre de pernil, calabresa e cachorros-quentes. ${ }^{69} \mathrm{O}$ programa de domingo das famílias e torcedores não era mais o mesmo, pois não mais utilizaram o Estádio Municipal como área de lazer ampla, mas apenas para assistir a jogos de futebol. Aos poucos, inclusive, as famílias foram substituídas pelas torcidas organizadas, as primeiras pelos clubes e, na década de 1960, as independentes formadas por jovens.

Desde a virada do século XIX, a cidade passou por diversos projetos de intervenção urbana. Alguns estudiosos falam na construção de três cidades no espaço de um século. ${ }^{70}$ As intervenções realizadas a partir das administrações de Fábio Prado e de Prestes Maia ganharam notoriedade pelo gigantismo das propostas e por desarticular características marcantes da cidade de São Paulo, as dos cafeicultores. O processo de modernização da nossa sociedade é uma bandeira das elites desde o final do século XIX, sempre com determinada condição: que a modernização não represente ameaça ao

${ }^{68}$ GLEZER, Raquel. Chão de terra e outros ensaios sobre São Paulo. Pág. 20. Nos dizeres da autora, " $a$ partir dos anos 1960, a transformação teve início: violenta explosão demográfica, adensamento vertical em todas as regiões criando um sky-line recortado e agressivo em toda a cidade e valorização das propriedades imobiliárias, deslocando parte dos habitantes para novas áreas. Simultaneamente, ocorreram grandes projetos de intervenção urbana, como o começo da implantação da rede de transporte metropolitano; a construção de grandes viadutos e avenidas de fundo de vale, acelerando a destruição das áreas verdes; e a invasão das várzeas dos córregos, ribeirões e rios."

69 SALUN, A. O. Op. Cit. Pág. 160. O depoimento de Agostinho Záccaro é esclarecedor sobre os piqueniques nas praças de esporte.

${ }^{70}$ TOLEDO, Benedito Lima. Op. Cit.. 
status político, social ou econômico. Outros autores falam da construção de uma ordem urbanística centrada numa espécie de pacto territorial, no qual a lei determina a menor parte do que foi construído, normalmente servindo para diferenciar e proteger os territórios das elites, pela da construção de barreiras invisíveis. ${ }^{71}$

A maior parte da população estava excluída dos processos decisórios e vivenciava um cotidiano material muito precário, razão pela qual criava mecanismos de sobrevivência e identidade por meio de condições materiais e simbólicas possíveis, tais como o futebol.

Durante boa parte do século XX, diversas áreas verdes resistiram ao processo de urbanização: a ocupação não deu conta de controlar os ritmos dos rios e suas enchentes, nem apagou os traços rurais de São Paulo. Diante da modernização, pelo fato de nem toda população aderir ao projeto, a cidade se transformou no palco das diversas temporalidades que envolviam seus habitantes, fossem brasileiros ou imigrantes, no qual os aspectos urbanos e modernos conviviam com o rural e arcaico. Essas populações tiveram que se adequar à nova realidade: bondes, energia elétrica, carros, grandes avenidas, arranha-céus, novas formas de lazer. Dentre as novidades, o futebol foi uma das que mais entusiasmaram a população.

Das chácaras aos estádios, o futebol transitou por diversos espaços da cidade autorizado ou não pela administração pública. Sua conversão em espetáculo de massa ocorreu no período que vai do início do século até o final dos anos 1930, quando, por iniciativa dos governantes autoritários do período varguista, alcançou o status de esporte profissional e passou a ser praticado em grandes estádios. Durante boa parte do período estudado, no entanto, os espaços utilizados para o futebol eram precários, campos improvisados, simples praças desportivas, para citar o termo predileto dos cronistas de então, algumas criadas para outros esportes e, depois, adaptadas às demandas do futebol.

A trajetória do futebol em São Paulo serve de metáfora do processo de urbanização da cidade, de como os espaços foram ocupados e degradados, das parcerias espúrias entre o poder público e os interesses privados das grandes empresas imobiliárias ou dos donos das antigas chácaras dos arredores da cidade. A seguir, aprofundaremos as discussões sobre essas relações entre poder público e interesses

\footnotetext{
${ }^{71}$ ROLNIK, R. Op. Cit. Págs. 13, 14 e 46.
} 
privados de toda ordem e como os diversos grupos sociais construíram a própria identidade por meio do esporte.

\title{
1.2 Improviso, colaboração e segregação. As relações entre o futebol de várzea e o futebol oficial.
}

\begin{abstract}
"When the county of São Paulo opened Pacaembu back on April 27, 1940, its size seemed sensational - Why so big a stadium? Many asked. There will never be a enough people to fill it up. But they had not reckoned with their city becoming the fatest-growing in the world, nor with the giant future achievements of Brazilian football.

For a time, Pacaembu seemed a gift from heaven. It had the advantage of encouraging the enthusiasm and pride of the Paulista - the name for a citizen of the city - but after a while, it produced a disadvantage: Pacaembu checked the private enterprise of the clubs. Their own grounds became abandoned and dusty, were thoroughly neglected.

This was Pacaembu's golden era. Everyone wished only to play there, it was the first stadium of Brazil. Rio claimed a close rival in the Vasco da Gama Stadium, but though it came near in capacity the Vasco ground had nothing of Pacaembu's modernity and majesty. But with the building of Maracanã, Pacaembu leadership was abruptly lost.",72
\end{abstract}

"Releva assignalemos que raramente no quadro maximo de S. Paulo figuram filhos de outras plagas. Quase todos nossos seleccionados são constituídos de paulistas genuínos e, o que é mais importante, jogadores esses feitos em campos e estádios que se esparramam, modestos ou sumptuosos, desde a capital até aos confins de nosso grande Estado."73

"O Velódromo foi o primeiro estádio de relevante importância do futebol paulista." $" 74$

O primeiro texto citado foi publicado no início dos anos 1960, na Grã-Bretanha. Trata-se de uma publicação que pretende apresentar a história do futebol brasileiro, de maneira breve e sucinta, para um público que descobrira a genialidade desse e estava profundamente interessado em dois personagens: Pelé e Garrincha. Interessante

\footnotetext{
${ }^{72}$ SMITH, Straton. The Brazil book of football. Londres, Souvenir Press, 1962. Pags. 116 e 117.

${ }^{73}$ SANTANNA, Leopoldo. Supremacia e decadência do futebol paulista. São Paulo, Instituto Ana Rosa, 1924. Pág. 54.

74 RIBEIRO, Rubens. O caminho da bola. 100 anos de história da Federação Paulista de Futebol. I Volume. São Paulo, Federação Paulista Pág. 22.
} 
observar o contraste existente entre o texto com a publicação da Federação Paulista de Futebol, por ocasião do centenário da entidade, ou com o depoimento de Leopoldo Santanna, um dos primeiros cronistas esportivos de São Paulo, em 1925.

Seguindo a tradição legada pelos cronistas da primeira metade do século $\mathrm{XX}, \mathrm{o}$ memorialista da Federação Paulista de Futebol defende a ideia de que o primeiro estádio paulistano foi o Velódromo Paulista. Ao lermos o depoimento de Santanna, ficamos com a impressão de que, na década de 1920, a cidade de São Paulo contava com diversos estádios, suntuosos ou modestos. O texto britânico indica que o primeiro estádio de futebol no Brasil foi o Estádio do Pacaembu.

Há indícios de que alguns autores tentaram criar uma esfera de sofisticação e complexidade para os espaços utilizados pela elite paulistana para a prática do futebol no início do século, o que não corresponde ao que esses espaços eram. A primeira partida do Campeonato Paulista, disputada no Parque Antarctica, ocorreu em um campo de futebol que não se diferenciava dos espaços utilizados pela população mais pobre na várzea do Carmo, como podemos verificar em fotografia do local, tirada em $1904 .{ }^{75}$

Em visita pela cidade no ano de 1910 com o time de futebol londrino Corinthian F.C., um jogador não identificado deixou um relato interessante sobre o campo de futebol que encontrou na cidade naquela ocasião: “... as the ground here cannot be called anything else but very bad." ${ }^{76}$ Ele comparou o campo utilizado em São Paulo ao utilizado no Rio de Janeiro alguns dias antes, considerando o do Rio superior.

\footnotetext{
${ }^{75}$ A foto encontra-se no Museu da Imagem e do Som de São Paulo, na Pasta 131, n. ${ }^{\circ}$ Fo.00007 Ep 003 , com a legenda "Campo do Parque Antártica. 1. a Corrida de automóveis no Brasil, 1904. Oswaldo Sampaio e Fausto Salles Sampaio. Fiat 4 cilindros". Não há identificação do autor da fotografia e o museu não autoriza sua publicação. NEGREIROS, Plínio José Labriola de Campos. Resistência e rendição. A gênese do Sport Club Corinthians Paulista e o futebol oficial de São Paulo (1910-1916). Pág. 48. O autor defende a ideia de que seria insensato separar o futebol praticado pelas elites do futebol praticado pelos grupos populares.

${ }^{76}$ Corinthian F.C. in Brazil. The Sportsman, 26/09/1910. Pag. 3. “... as the ground here cannot be called anything else but very bad. Like the Fluminense ground, of course, it is hard and dry, but unlike the Fluminense ground, it is extraordinarily rough, with very little grass on it, and that grass of the regular coarse Brazilian kind, and not the fine grass we played in the Rio." "...como o campo aqui não pode ser chamado de outra coisa além de muito ruim. Como o campo do Fluminense, é claro, ele é duro e seco. Mas diferentemente do campo do Fluminense, é extraordinariamente tosco, com pouca grama e aquele tipo de grama típica do Brasil e não aquela fina que utilizamos no Rio”. Em entrevista concedida ao periódico A Gazeta Esportiva em 1930, Miguel Sottile, um dos fundadores do Corinthians Paulista, afirma que o jogo ocorreu no Velódromo Paulista. Reconstituindo a história do Corinthians. A Gazeta Esportiva. 07/09/1930.
} 
A grande diferença entre os espaços utilizados pela elite e pelos grupos populares residia no impedimento que existia para que indivíduos de determinados grupos sociais frequentassem os mesmos espaços da elite paulistana. A análise dos documentos produzidos por pessoas não relacionadas à elite ou memórias colhidas em outras regiões nos permite perceber como se deu o processo de construção da memória do futebol paulistano. Os aspectos ideológicos do processo nos levam a acreditar que o futebol era elitizado e sofisticado no início do século, quando, provavelmente, era improvisado e quase sempre rudimentar entre todos os grupos que o praticavam.

Tal processo silenciou a participação de diversos atores que estiveram envolvidos com o futebol no decorrer de todo o século XX de maneira ativa e permitiu a construção de um imaginário identificado com apenas alguns segmentos da sociedade. Imaginário que legitima o exercício de poder desses grupos que ainda hoje controlam o futebol da cidade, do Estado e do País, de maneira autoritária, auferindo lucros com o esporte.

Nas primeiras décadas de futebol em São Paulo, as queixas dos cariocas sobre o estado dos gramados eram constantes, como podemos ler no discurso de Santanna, acerca das rivalidades entre cariocas e paulistas:

"Capítulo dos mais interessantes seria que historiasse com todos os pormenores a grande grita entre jornalistas esportivos cariocas e paulistas em torno de inesperadas derrotas... Mau grado nossos desejos, não nos abalançamos a tal empreendimento porque seria afastarmo-nos muito de nosso ponto de vista. Todavia, não podemos deixar de assignalar que é velha cantilhena o processo da mor parte da imprensa carioca em desculpar-se dos fracassos das turmas representativas da Capital da República, jogando toda a responsabilidade para as largas costas dos juízes quando não attribuem o insucesso ao mau estado do campo, a torcida e quejandas cousas...,"77

O futebol naquele contexto era jogo disputado nos campos ou ruas, de maneira improvisada. O depoimento de Jorge Americano é revelador:

"O gol era marcado pelo lampião, de um lado, e por dois tijolos, do outro, no quarteirão da Rua Conselheiro Nébias, entre a Rua Helvetia e Alameda Glette. Não passava veículo senão de meia em meia hora. A bola era feita com enchimento de papel, revestida com meias velhas e amarrada com barbante.

\footnotetext{
${ }^{77}$ SANTANNA, Leopoldo. Op. Cit. Págs. 25 e 26.
} 
Ficava do tamanho de uma laranja. De vez em quando quebrávamos a vidraça de um lampião. Não dava incidente maior. De vez em quando, quebrávamos a vidraça de uma das casas, todas iguais, pertencente à dona Vitória de Almeida Lima. Corríamos todos, escondíamos atrás do pequeno saguão externo de cada casa e uns minutos depois, vínhamos aparecendo. Não dava incidente maior."78

Prática de jovens e crianças que apenas queriam se divertir quando introduzido em São Paulo ${ }^{79}$, com o passar dos anos, o futebol adquiriu novos contornos como os de espetáculo altamente rentável para aqueles que o controlassem e o explorassem. Esta transformação se deu por meio das relações entre modernidade e juventude que eram e ainda são indissociáveis, muitas vezes intercambiantes, ${ }^{80}$ e teve altos e baixos, inclusive com o desinteresse por muitas partidas, como podemos aferir da nota publicada pelo periódico $O$ Imparcial.

"Embora se diga aos quatro ventos que o futebol vai tomando novo incremento, adquirindo a primazia dos esportes em São Paulo, para nós, afigura-se que nunca esteve tão desanimado (...) Basta dizer que o veterano São Paulo Athletic se retirou da liga e que o campeonato disputado de junho a dezembro sem o menor interesse (...) tudo isso contribuiu para que o público se afastasse do Velódromo e que não se realizassem os quatro matches finais."

Essas relações não implicavam a pura e simples eliminação de um grupo social em detrimento de outro dentro dos espaços dedicados ao futebol, tão pouco acabavam com as práticas relacionadas ao lazer, mas implicavam, dentre os participantes e entusiastas, saber quem conseguiria ou teria interesse em obter e reter os dividendos gerados pelo espetáculo, além de determinar o espaço que cada um viria a ocupar dentro desse espetáculo. Em alguns casos, a cumplicidade foi vital para a manutenção e ampliação dos simpatizantes, assim como a organização de partidas, tal como sugere Maria Inez M.B. Pinto, quando indica que as distâncias sociais entre filhos de patrões e empregados eram menores na infância. ${ }^{82}$

\footnotetext{
${ }^{78}$ AMERICANO, J. São Paulo naquele tempo (1895-1915). Pág. 345.

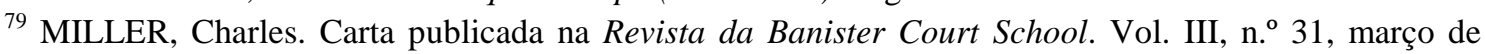
1904. (In): HAMILTON, Aidan. Um jogo inteiramente diferente! Futebol: A maestria brasileira de um legado britânico. Rio de Janeiro, Gryphus, 2001. Pág. XXIII.

${ }^{80}$ HOBSBAWN, E. A Era dos Impérios. Rio de Janeiro, Paz e Terra, 1998. Pág. 239.

${ }^{81}$ SALUN, A. O. Op. Cit. Pág. 44; O Imparcial, 15/04/1913.

${ }^{82}$ PINTO, Maria Inez M.B. Cotidiano e Sobrevivência. São Paulo / FAPESP, 1994. Pág.104.
} 
Não era no momento da brincadeira ${ }^{83}$ ou da descontração infanto-juvenil que se dava a segregação. Mas o desenvolvimento de espaços diferentes na cidade para os diversos grupos sociais praticarem futebol mostra que o processo que transformou o futebol em espetáculo de massa foi marcado por exclusões e conflitos de todas as ordens, até culminar com a profissionalização e a criação da Federação Paulista de Futebol no governo Vargas, nas décadas de 1930 e 1940.

O processo de modernização levado adiante pelas elites brasileiras pressupunha a reurbanização dos centros das cidades ou a criação de novas áreas que permitissem o afastamento entre os grupos dirigentes e os grupos subalternos. Segundo Raquel Rolnik, a segregação como elemento estruturador da cidade já estava em curso no último quartel do século XIX, a partir da explosão demográfica que atingiu São Paulo na década de $1890,{ }^{84}$ período em que o futebol foi introduzido na cidade.

No futebol paulistano, a situação decorrente desse fenômeno foi o aparecimento de núcleos futebolísticos populares nos bairros ocupados pelos trabalhadores, que, com o passar dos anos, foram genericamente denominados de futebol de várzea ou varzeano, e núcleos exclusivos para a elite, denominados de futebol oficial.

A denominação dada ao futebol praticado pelos grupos pobres da cidade futebol varzeano - decorria do uso das margens dos rios e áreas adjacentes para a prática de futebol. O que era possível porque as várzeas da cidade apresentavam um limite para certos processos urbanos como habitações ou unidades industriais, já que eram superfícies inundáveis. ${ }^{85} \mathrm{~A}$ implantação das ferrovias desde o século XIX em áreas próximas, mas protegidas das inundações, transformou algumas áreas de várzea em redutos industriais, de concentração de depósitos e armazéns, além de lugar de atração para aqueles que buscavam trabalho, moradia mais barata ou lazer.

Aos poucos, a noção de várzea tornou-se mais abrangente e com o processo de ocupação das margens do rio Tietê, as áreas além dos trilhos da linha de trem entre a

\footnotetext{
83 DAMATTA, R. Carnavais, malandros e heróis. Para uma sociologia do dilema brasileiro. Rio de Janeiro, Rocco, 1997. Pág.126. O autor informa que o verbo brincar deriva de brinco, do latim vinculu: elo, relação.

${ }^{84}$ ROLNIK, Raquel. Op. Cit. Pág. 28.

${ }^{85}$ SEABRA, O. C.L. Os meandros dos rios nos meandros do poder. Tietê e Pinheiros - Valorização dos rios e das várzeas na cidade de São Paulo. Tese de doutoramento apresentada ao Departamento de Geografia da FFLCH - USP, 1987. Pág. 78. Segundo a autora, o termo varzeano ganhou uma conotação pejorativa de pessoa pobre e suja em decorrência das cheias que levavam água e lixo para dentro das casas dos habitantes pobres dessas áreas. Pág. 104.
} 
Lapa e a Barra Funda em direção ao rio Tietê ou entre a Avenida Celso Garcia e o mesmo rio também foram tratadas pela população como várzeas. ${ }^{86} \mathrm{O}$ mesmo processo ocorreu com as margens do rio Tamanduateí, ampliando-se posteriormente para abranger todos os habitantes de regiões sujeitas às enchentes nas várzeas de outros riachos e córregos da cidade. As populações pobres que ocupavam essas áreas ficavam conhecidas como varzeanas.

O futebol popular praticado pelos pobres e os clubes que dele tomavam parte recebeu o apelido na dinâmica de desqualificação social que o termo trazia. Era o futebol popular, pequeno ou varzeano em contraposição ao futebol oficial praticado pelas elites. Os times eram formados por grupos de profissionais, de amigos de rua ou bairro, de escola, de parentes; sua consolidação no meio futebolístico dependia do êxito alcançado nas partidas, razão pela qual os times se formavam, se desfaziam e se refaziam em profusão. ${ }^{87}$

A primeira região utilizada por essa população mais pobre para a prática do futebol no início do século XX ficava às margens do rio Tamanduateí, em uma área que, durante o verão, era invadida pelas águas do rio que transbordava em decorrência das chuvas, mas que, nas outras épocas do ano, ficava propícia para o jogo de futebol. Essa área era conhecida como várzea do Carmo, pela proximidade com a igreja do Carmo e a ladeira de mesmo nome, que ligava a parte alta, formada pelo tradicional triângulo da cidade, com a várzea. ${ }^{88}$

Alguns autores falam que os primeiros times já atuavam naquela área por volta de 1902. Miller relata a existência de uma equipe em cada bairro da cidade já por volta

\footnotetext{
${ }^{86}$ SEABRA, O. C. L. Op. Cit. Pág. 105. Segundo a autora, as várzeas do rio Pinheiros tiveram outra dinâmica em decorrência dos acordos entre o poder público e a Light (empresa responsável pelo fornecimento de energia para a cidade de São Paulo desde 1900), que monopolizou a exploração da área por boa parte do século XX. Ver, em especial, capítulo em que discute a concessão para a Light. Na página 225, há a informação de que a Light tentava impedir o uso da várzea do rio Pinheiros para a prática do futebol.

${ }^{87}$ SEABRA, O. C. L. Urbanização e fragmentação. Cotidiano e vida de bairro na metamorfose da cidade em metrópole, a partir das transformações do bairro do Limão. Livre Docência apresentada ao Departamento de Geografia da FFLCH-USP, 2003. Pág. 340. (ou 438).

${ }^{88}$ A antiga ladeira foi transformada na Avenida Rangel Pestana e é uma das ligações do centro de São Paulo com a Zona Leste através da Avenida Celso Garcia, continuação da Rangel Pestana. A igreja, reformada no decorrer do século XX, permanece no mesmo lugar, mas, escondida pelos altos edifícios do entorno, não produz o mesmo impacto na paisagem urbana que produzia até o início do século.
} 
de 1904, em uma quantidade próxima a sessenta equipes. ${ }^{89}$ Para Mazzoni, os primeiros times teriam surgido por volta de 1903:

"O exemplo dos estudantes e dos moços ricos do Mackenzie, Paulistano etc. não deixou indiferentes os rapazes operários dos bairros e daí surgirem pequenos clubes em pouco tempo. Assim, si consultarmos, por exemplo, os jornais de 1903, leremos em duas ou três linhas que estão combinados para hoje alguns match de football, no ponto final do Tranway da Cantareira, entre os clubes A.A. Cruzeiro Paulista x A.A. Santos Dumont e S.C. Silvio de Almeida x S. C. Guarani." 90

Identificar quais foram os primeiros clubes e seus jogadores era um problema em 1930, pois a precariedade das sedes dos clubes, quase sempre improvisadas, impedia a criação e preservação de acervos documentais e memorialísticos. Nessa época, existiam cerca de 600 equipes varzeanas atuando pelos campos da cidade. ${ }^{91}$ Segundo o periódico A Gazeta Esportiva, havia grande controvérsia sobre esse tema. Times como o Domitilla F.C., Minerva F.C., Parahyba F.C. (este trocou de nome diversas vezes, primeiro para Minas Gerais, depois para Braz Athlético e Auto F.C.), Parada Zero F.C., Arco Íris F.C., Vinte e Cinco de Março F.C. despontaram como os pioneiros, atuando na várzea do Carmo. ${ }^{92}$ Ao findar a primeira década do século, já atuavam no mesmo espaço as equipes do Onze de Agosto F.C., do Bello Horizonte, Botafogo F.C., Cruzeiro do Sul, Argentino F.C., Mackenzinho F.C., Guapirano F.C., Enotria F.C., A.A. Maranhão e Lazio F.C. ${ }^{93}$

Os times eram formados por moradores dos bairros próximos, como o Brás (Minas Gerais), e o Bom Retiro (Bello Horizonte e Botafogo) ou mesmo das adjacências da várzea do Carmo (Vinte e Cinco de Março), ou por funcionários de

89 ANTUNES, Fátima R.F. Futebol de Fábrica em São Paulo. Dissertação de mestrado, FFLCH-USP, 1992. Pág. 19; NEIVA, Adriano. Escrevendo uma história. (In): 60 anos de futebol no Brasil; São Paulo, Federação Paulista de Futebol, 1955. MILLER, Charles. Carta publicada na Revista da Banister Court School. Vol. III, n. ${ }^{\circ}$ 31, março de 1904. (In): HAMILTON, Aidan. Op. Cit.. É bom lembrar que apenas cinco equipes tomaram parte do primeiro campeonato organizado pela Liga Paulista de Futebol naquele ano.

${ }^{90}$ MAZZONI, T. Op. Cit. Pág. 77.

${ }^{91}$ Os dez "azes"! Ainda o lufa-lufa em torno dos nossos melhores quadros varzeanos - Os campeões de antigamente. A Gazeta Esportiva, 22 /06/1930, Pág. 9.

92 A várzea de todos os tempos! Pequenos factos que muito aficionado suburbano ignora. A Gazeta Esportiva, 5 de maio de 1930, Pág. 8.

93 Os dez "azes"! Ainda o lufa-lufa em torno dos nossos melhores quadros varzeanos - Os campeões de antigamente. A Gazeta Esportiva, 22 de junho de 1930, Pág. 9. 
empresas que ficavam no entorno da várzea do Carmo (Domitilla). Esse último era formado por funcionários da São Paulo Railway, cuja sede em São Paulo ficava próxima à várzea e tinha Charles Miller como treinador. Aos poucos, nos bairros mais distantes surgiram times que se encaminhavam para a várzea do Carmo a fim de disputarem partidas e campeonatos que ali eram organizados.

Para Mazzoni, dentre os jogadores que se destacaram, estavam o Antenor (goleiro do Aliança, que, segundo o cronista, teve mais fama do que qualquer craque do Velódromo), Edmundo e Paulino (zagueiros), Augusto de Campos e Alziro Veridiano (dois ótimos meias), Rafael Farina, Zé Cabeludo e Menotti (da linha média), Peru, Afonsinho e Ambrósio (atacantes). ${ }^{94} \mathrm{O}$ mesmo autor ainda apresenta os nomes de Ema (goleiro), Ulbano Zuppa, Couto, Gervásio, Patureau, Pedro Paulo di Giovanni, João Rego e Hermann Ewald, mas sem qualquer referência sobre a origem ou o time em que atuavam.

Na década de 1910, durante a gestão de Raimundo Duprat, a região sofreu uma profunda intervenção urbanística da Prefeitura e foi transformada em um grande parque que recebeu o nome de Parque D. Pedro, inaugurado por ocasião do centenário da Independência do Brasil, em 1922. A várzea saneada trouxe a valorização dos terrenos adjacentes e a destruição dos casebres que a cercavam. ${ }^{95}$ O futebol varzeano, em diáspora, espalhou-se para outras regiões da cidade.

Podemos inferir da própria participação de Miller como técnico em uma equipe que atuava na várzea do Carmo que a separação entre o futebol oficial e o futebol varzeano não era automática e decorria das disputas e rivalidades que surgiram com o desenvolvimento do esporte na cidade, da crescente importância atribuída ao futebol pelos moradores e da necessidade das novas classes médias e elites urbanas de criarem mecanismos de distanciamento e controle dos grupos subalternos. Isto não significa, no entanto, que esses grupos subalternos não praticassem futebol ou se envolvessem com o esporte como torcedores/simpatizantes.

Os símbolos de modernidade hipnotizavam e seduziam os jovens de todos os grupos sociais. Nem todos podiam usufruir das novidades modernas trazidas da Europa,

\footnotetext{
${ }^{94}$ MAZZONI, T. Op. Cit. Pág.77.

95 MARINS, P. C. G. Habitação e vizinhança. Limites da privacidade no surgimento das metrópoles brasileiras. (In): SEVCENKO, N. (org.). História da Vida Privada no Brasil. Vol. III. República. Da Belle Epóque a Era do Rádio. São Paulo, Cia. Das Letras, 1998. Pág. 181.
} 
exceto quanto ao futebol, pois sua prática não exigia vultosos investimentos: um campo baldio, um grupo de adolescentes e jovens, uma bola de futebol e disposição. Para os grupos subalternos da sociedade paulistana, o futebol, fundado na lógica da improvisação, poderia ser visto como uma forma de constituir um modo de representação da existência negada em outros campos sociais, algo como o tempo da exceção, o tempo fora do dia a dia marcado pelo trabalho e pelas relações e regras do tempo comum, ${ }^{96}$ o espaço construído pelos arautos da modernidade em que era possível reforçar as características da infixidez, o jogo e os reajustamentos constantes que garantiam maiores oportunidades no confronto social. ${ }^{97}$

Adquirir uma bola de futebol no início do século era o grande problema para esses jovens, pois esta chegava a custar $15 \$^{98}$ e as dificuldades para comprá-la eram enormes, o que obrigava os times formados por jovens pobres a promover coletas de dinheiro entre os interessados em jogar futebol ou pedir apoio de pequenos comerciantes do bairro. Muitas vezes, diante das dificuldades encontradas para comprar uma bola, as formas de consegui-las eram outras, como podemos perceber no relato que segue e no exposto por Jorge Americano ${ }^{99}$ sobre como a criançada improvisava uma bola.

${ }^{96}$ GONÇALVES, René Duarte Jr. Friedenreich e a reinvenção de São Paulo. O futebol e a vitória na fundação da metrópole. Dissertação de mestrado apresentado ao Departamento de História da FFLCHUSP, 2008. Págs. 13 e 34. Franco, Hilário. A dança dos deuses. São Paulo, Cia. das Letras, 2007. Pág. 64. ${ }^{97}$ SEVCENKO, N. História da Vida Privada no Brasil. Vol. III. República. Da Belle Epóque a Era do Rádio. São Paulo, Cia. Das Letras, 1998. Págs. 610 e 611. FlORENZANO, J.P. A democracia corinthiana. São Paulo, EDUC, 2009. Pág. 29. O autor chama a atenção para o processo de correlação existente entre os trabalhadores da fábrica e os trabalhadores da bola na reelaboração da prática do futebol. Segundo o autor, havia o esvaziamento dos sentidos que orientavam na direção da ordem social e a construção do futebol como um campo de batalha entre visões de mundo antagônicas, sedimentado por tradições culturais divergentes, atravessado de tensões, contradições e linhas de força traçadas por inúmeros sujeitos coletivos, os quais ora se articulam em estratégias comuns, ora se contrapõem mediante correlações de poder cambiantes, às vezes instáveis, a determinar uma reviravolta no posicionamento dos atores.

98 A várzea de todos os tempos! Pequenos factos que muito aficionado suburbano ignora. A Gazeta Esportiva, 04/05/1930. Pág. 8. Em 1930, uma bola custava entre 30\$ e 80\$. MARINS, Paulo César Garcez. Habitação e vizinhança. Limites da privacidade no surgimento das metrópoles brasileiras. (In): SEVCENKO, Nicolau (org.) História da Vida Privada no Brasil. Vol. III. Pág. 174. Para uma simples comparação, Marins afirma que, no início do século, no cortiço do senhor Joaquim Antunes, na Mooca, o aluguel de um cubículo custava $30 \$ 000$ por mês. ROLNIK, R. A cidade e as leis. Legislação, política urbana e território na cidade de São Paulo. Pág. 114. Segundo a autora, o salário de um pedreiro girava em torno de $3 \$ 000$ a jornada. Os trabalhadores mais qualificados chegavam a ganhar $12 \$ 000$.

${ }^{99}$ AMERICANO, Jorge. São Paulo naquele tempo (1895-1915). Pág. 345. 
"O veterano clube da Luz surgiu em um frio dia de agosto de 1907 quando cinco meninos passavam próximos a um paredão onde hoje se ergue o majestoso edifício do Lyceu Coração de Jesus. De um fortíssimo chute, dado de dentro do collegio, uma bola com camara de ar (!) veio parar á rua... Os garotos que não eram lá para muita conversa, apanharam a pelota e correram."100

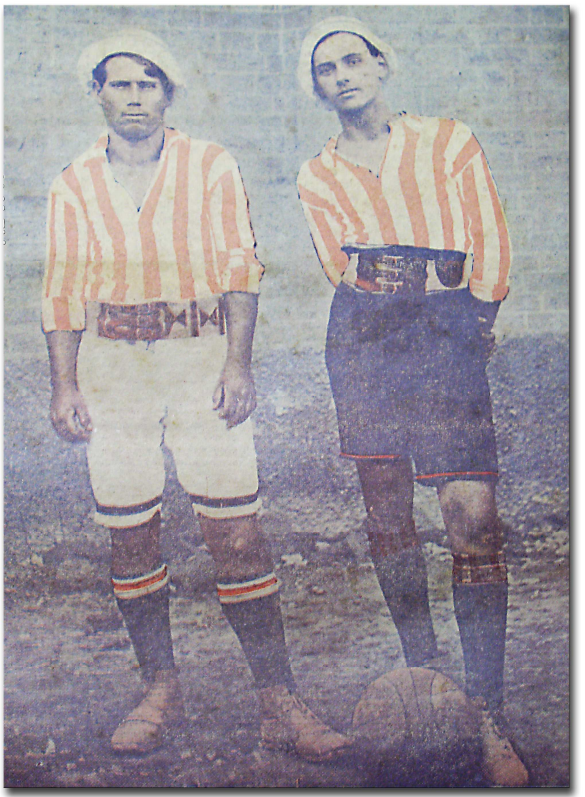

3. Jovens jogadores de futebol do bairro do Bom Retiro. À direita, Amílcar Barbuy em início de carreira.

Com o desenvolvimento das atividades esportivas e o aparecimento de bons resultados desses novos times, a tendência era a de que os comerciantes e, posteriormente, os grandes empresários assumissem a direção dos clubes, disponibilizassem a sede dos comércios para servir de sede social - era muito comum o uso de bares, padarias e barbearias para esse fim -, organizassem as respectivas finanças por meio de patrocínios, permitindo a esses times pleitear a participação nos campeonatos oficiais ou a disputa de partidas amistosas contra os times que os disputavam. Criava-se uma cumplicidade entre pequenos comerciantes, donos de terrenos e os times, o que permitia a aferição de lucros por parte dos primeiros e o crescimento dos times.

Do ponto de vista dos times e entusiastas, existia a dependência em relação aos terrenos utilizados como campos de futebol, que, a partir da segunda metade do século XX, definiria a sobrevivência ou desaparecimento desses times de várzea. Daí, a necessidade sistemática que os jovens pobres tinham em transformá-los em clubes e adquirir suas sedes. Aqueles que não se organizaram e conquistaram suas sedes desapareceram rapidamente. Segundo o depoimento do Sr. Amadeu,

"Cada campo tinha um clube; a maior parte dos campos eram dados pelos donos para o lugar progredir, popularizar. O dono é que pedia para fazerem um campo

\footnotetext{
${ }^{100}$ Bello Horizonte F. C. passa hoje o 23. ${ }^{\circ}$ aniversário do tradicional clube da Luz. A Gazeta Esportiva, 17/08/1930. Pág. 4.
} 
nesses terrenos baldios. Quando tinha um clube, vinha o progresso. No domingo vinham duas mil pessoas assistir, e começava o comércio, o progresso." 101

Muito provavelmente, processo semelhante ocorreu com a Chácara Dulley nas décadas de 1880 e 1890. Os donos da chácara permitiram sua utilização para práticas esportivas pelos sócios do São Paulo Athletic Club e na sequência a lotearam.

Em poucos anos, alguns empresários descobriram o potencial do futebol e o utilizaram para estabelecer a mesma cumplicidade com os funcionários, permitindo o desenvolvimento do esporte entre os operários e o aparecimento de times dentro das fábricas. Quase todos os times de fábrica tiveram seus campos e sedes nas áreas de várzea, assim como os times de bairro. A distinção entre eles era muito frágil, pois quase sempre disputavam partidas e campeonatos entre si ou eram formados por amigos, parentes, colegas e vizinhos.

Aqueles que jogavam pelos times de fábrica se utilizavam do patrocínio ou da infraestrutura oferecida pelos patrões para se divertirem. Aos poucos, passaram a usufruir benefícios não disponíveis para aqueles que não jogavam pelo time da empresa, como folgas para treinos, promoções mais rápidas e funções mais leves dentro do sistema produtivo. ${ }^{102}$ Em contrapartida, difundiam o nome da companhia ou de seus produtos pelos campos da cidade em que disputavam partidas de futebol. ${ }^{103}$

Ao estudar o futebol desenvolvido nas fábricas em São Paulo, Fátima Antunes apresenta os interesses de seus empresários em torno da formação de seus times: domesticação dos corpos dos funcionários para o trabalho, construção de uma identidade entre patrões e funcionários e o suporte publicitário barato para as

101 BOSI, Ecléa. Memória e Sociedade. Lembranças de velhos. São Paulo, Cia. das Letras, 1994. Pág. 138. ROLNIK, Raquel. A cidade e a lei. Legislação, política urbana e territórios na cidade de São Paulo. Fapesp/Studio Nobel, São Paulo, 1997. Pág. 50. A respeito do processo de ocupação da cidade, Rolnik fala de uma dualidade legal/extralegal que permitiu a preservação do território da elite da invasão de usos indesejados e degradantes, protegendo o valor imobiliário dessas residências e, ao mesmo tempo, acomodando a explosiva demanda por habitações.

${ }^{102}$ ANTUNES, Fátima R.F. Op. Cit. Pág. 40. Nesta pesquisa, a autora apresenta como se dava o processo de seleção daqueles que poderiam participar da equipe de uma determinada fábrica e mostra que o processo era marcado por conflitos entre os operários que jogavam e os que não conseguiam jogar porque eram considerados maus jogadores.

${ }^{103}$ ANTUNES, Fátima R.F. Op.Cit. Pág. 4. 
empresas. ${ }^{104}$ A mercantilização do futebol foi vislumbrada por diversos empresários em um processo que deu origem a times como o São Paulo Railway (atual Nacional Atlético Clube) e o Cotonifício Rodolfo Crespi F. C. (atual Clube Atlético Juventus). Evidentemente, aos empresários caberia o papel proeminente e aos operários, o subalterno, dentro da hierarquia desses clubes.

O processo tomou tal vulto que a Light se orgulhava de ter organizado a primeira partida noturna da história do futebol em um campo utilizado por seus funcionários em terreno da própria companhia no bairro do Cambuci, bairro também varzeano, que fica às margens do rio Tamanduateí, ao sul da várzea do Carmo, em 1923. A partida foi disputada pelas equipes Sociedade Esportiva Linhas e Cabos, formada por funcionários da Light e a Associação Atlética República, e foi internacionalmente reconhecida como um feito da empresa. ${ }^{105}$

A preocupação com o lazer e o divertimento dos trabalhadores nem sempre estava em questão, razão pela qual, após o encarecimento das atividades desses times de fábrica com a profissionalização, quase todas as empresas que não tiveram êxito nas competições desistiram de patrociná-los ou procuraram não envolvê-los com o incipiente futebol profissional. A partir daí, essas equipes se organizaram em ligas específicas como a LECI (Liga das Entidades Comercialinas e Industriais), disputaram partidas e campeonatos com os clubes de bairro ou varzeanos, ou simplesmente desapareceram. $^{106}$

Da várzea do Carmo, o futebol varzeano se espalhou por todos os bairros da cidade, ocupou os terrenos disponíveis, dentro do processo de urbanização, até alcançar a impressionante marca de 600 equipes em 1930. ${ }^{107}$ Entre os anos 1930 e 1970, todas as

\footnotetext{
104 ANTUNES, Fátima R.F. Op.Cit. Págs. 38, 39 e 101. Embora distribuíssem material esportivo e concedessem o espaço para os times, a liberação de verbas para esses times quase sempre era um problema, segundo o depoimento de um funcionário da Light citado pela autora.

105 ANTUNES, Fátima R.F. Op.Cit. Pág. 67. Segundo a autora, a revista norte-americana Electrical World documentou o fato em 1924. A partida ocorreu no dia 24 de junho de 1923, no campo que se situava na rua do Glicério.

106 ANTUNES, Fátima R.F. Op.Cit. Pág. 133. Entre tantas equipes, essa teria sido a trajetória da Associação Atlética Matarazzo entre as décadas de 1940 e 1950.

107 Os dez "azes"! Ainda o lufa-lufa em torno dos nossos melhores quadros varzeanos - Os campeões de antigamente. A Gazeta Esportiva, 22 de junho de 1930, Pág. 9. O documento não informa se esses clubes eram organizados nos bairros ou em fábricas. No Álbum futebolístico de São Paulo, preparado pela Federação Paulista de Futebol em 1956, não existe uma diferenciação ou separação no trato entre estes clubes e times, tratados todos como varzeanos. É importante lembrar que, assim como alguns times de
} 
áreas próximas aos córregos e rios da cidade se converteram em espaços utilizados para o futebol. Apenas no início dos anos 1970, as avenidas tomaram, definitivamente, o lugar dos campos e clubes.

A atuação da Prefeitura em relação à várzea do Carmo e a criação da Chácara da Floresta ajudaram a disseminar pelas várzeas da cidade o futebol praticado pelos grupos pobres da cidade. Em algumas ocasiões, o futebol era integrado nas práticas festivas, religiosas e paroquiais tão características dos bairros. ${ }^{108}$ Com o processo de massificação e espetacularização, o futebol construiria um espaço autônomo de lazer em relação à religião e ao paroquismo na construção de identidades diretas com os bairros e seus moradores. ${ }^{109}$

Os nomes dos times varzeanos, com o tempo, passaram a se remeter aos locais de origem. Alguns se remetiam à filiação política de seus fundadores e simpatizantes ou à origem nacional dos indivíduos. ${ }^{110}$

Em alguns casos, os times de várzea chegaram a ser os coletivos que se assumiam perante a cidade enquanto representantes dos seus bairros. ${ }^{111}$ Era uma conjunção de festa, de lúdico, de sagrado e profano, de família, de muitos amigos, de muita atividade que contava com a presença do padre e de políticos. ${ }^{112}$ Para Burke, "estas instituições voluntárias a meio caminho entre o mundo privado e o mundo público contribuíram para o surgimento do que hoje é chamado de sociedade civil." 113 Na prática, todo bairro de São Paulo possuía um ou mais clubes que se dedicavam ao esporte. Mais uma vez, o depoimento do Sr. Amadeu nos esclarece sobre a relação entre os bairros e seus times e campos de futebol, no final dos anos 1920, um pouco antes da profissionalização:

bairro ascenderam ao futebol oficial (depois profissional), alguns desses times de fábrica também vivenciaram o mesmo processo como o Juventus ou o Nacional, mencionados.

108 SEABRA,O.C.L. Op. Cit. Pág. 140 (ou 170).

${ }^{109}$ SEABRA,O.C.L. Op. Cit. Pág. 277 (ou 375).

${ }^{110}$ SEABRA,O.C.L. Op. Cit. Pág. 361 (ou 429). A autora sugere a necessidade de se aprofundarem os estudos para que se possa compreender outros aspectos importantes dessas agremiações como o uso constante de nomes como Flor e Estrela, assim como as relações entre estes nomes e os utilizados por diversas padarias paulistanas.

${ }^{111}$ SEABRA,O.C.L. Op. Cit. Pág. 364 (ou 432).

${ }^{112}$ SEABRA,O.C.L. Op. Cit. Pág. 389 (ou 487).

${ }^{113}$ BURKE, Peter. A história social dos clubes. Folha de S. Paulo. 24/02/2002. 
"Naquele tempo tinha mais de mil campos de várzea. Na Vila Maria, no Canindé, na Várzea do Glicério, cada um tinha mais ou menos cinqüenta campos de futebol. Penha, pode pôr cinqüenta campos. Barra Funda, Lapa, entre vinte e vinte e cinco campos. Ipiranga, junto com Vila Prudente, pode pôr uns cinqüenta campos. Vila Matilde, uns vinte." 114

Com a profissionalização, as equipes varzeanas e de fábrica se consolidaram como trampolim para jogadores novatos despontarem antes de serem descobertos pelos olheiros $^{115}$ e ingressarem nos times profissionais, como espaços para os jogadores aposentados do futebol oficial ou profissional atuarem e mantiveram a prática futebolística independente do futebol espetáculo/profissional muito procurado e apreciado pelos grupos populares da cidade nos momentos de lazer.

A partir da década de 1970, com a ocupação acelerada dos terrenos por construções, ruas e avenidas, muitos clubes desapareceram e a prática do futebol de várzea se enfraqueceu, sem, no entanto, desaparecer.

${ }^{114}$ BOSI, Ecléa. Op. Cit. Pág. 138.

${ }^{115} \mathrm{O}$ olheiro é aquele indivíduo que descobre um talento e o leva para um time de grande projeção. Na atualidade, convive com ou se transforma em empresário dos novos talentos que despontam nos gramados brasileiros, anualmente. Atua como intermediário entre o atleta, o pequeno clube, os grandes clubes brasileiros e os clubes estrangeiros. 


\title{
2 Polissemia. O futebol e seus múltiplos significados na sociedade paulista.
}

\subsection{Além do elitismo das primeiras ligas. ${ }^{116}$}

\begin{abstract}
"Após a disputa do Campeonato Brasileiro de Futebol, em 1924, a imprensa da Capital da República assestou as suas baterias contra São Paulo. E - salvo excepções honrosas - numa verdadeira linguagem de labrego, o esporte da terra dos bandeirantes soffreu os mais ferinos remoques. E tudo girava em torno da pretensa superioridade technica do futebol carioca... Chegaram mesmo a gritar, alto e bom som, serem os paulistas discípulos dos cariocas (Rio-Jornal, de 5 de janeiro de 1925), e que, no tempo da Liga Metropolitana, já éramos por elles vencidos, embora com difficuldade, e que presentemente, devido à reorganização que passou o esporte, no Rio, os paulistas são derrotados facilmente...,
\end{abstract}

"No jogo devem fazer parte onze jogadores de cada lado, sendo eles colocados da seguinte maneira: o guarda-meta no número um; os zagueiros nos números dois e três; os médios nos números quatro, cinco e seis; os dianteiros nos números sete, oito, nove, dez e onze, formando nessa disposição um quadro. (...) O jogo começará com a bola no centro do campo; em seguida, sorteado o dado, o número verificado soma-se com o número nove (simplesmente para início do jogo); o produto, então, somado sucessivamente pelos números que forem sendo sorteados pelo dado, irá atingindo os números que se verificam no campo, para os quais devem ser sempre transportados a bola e os respectivos jogadores."

O futebol praticado pelas elites paulistanas, organizado por meio de ligas desde o início do século XX se consolidou como o futebol oficial, e, posteriormente a 1930, deu origem ao futebol profissional. O termo oficial deriva da organização do primeiro campeonato de futebol em São Paulo (talvez do Brasil) e denota o poder simbólico,

\footnotetext{
${ }^{116}$ As primeiras ligas de futebol em São Paulo foram a LPF: Liga Paulista de Futebol; APEA/APSA: Associação Paulista dos Esportes Atléticos; e a LAF: Liga Amadora de Futebol.

117 SANTANNA, Leopoldo. Op. Cit. Pág. 9.

${ }^{118}$ FRANZINI, Fábio. Corações na ponta da chuteira. Capítulos iniciais da história do futebol brasileiro (1919-1938). São Paulo, DPA, 2003. Págs. 51 e 52. Jogo de tabuleiro lançado em 1931 em propaganda do periódico A Gazeta Esportiva.
} 
econômico e político que esses grupos detiveram entre os praticantes do futebol da cidade por se organizarem antes e conseguirem aferir bons lucros com o negócio.

Além do mais, o termo futebol oficial dava a prerrogativa para aqueles que o controlavam de dizer quem poderia e quem não poderia jogar futebol nos espaços que eram considerados nobres ou melhores, que recebiam cobertura midiática maior e geravam as melhores rendas.

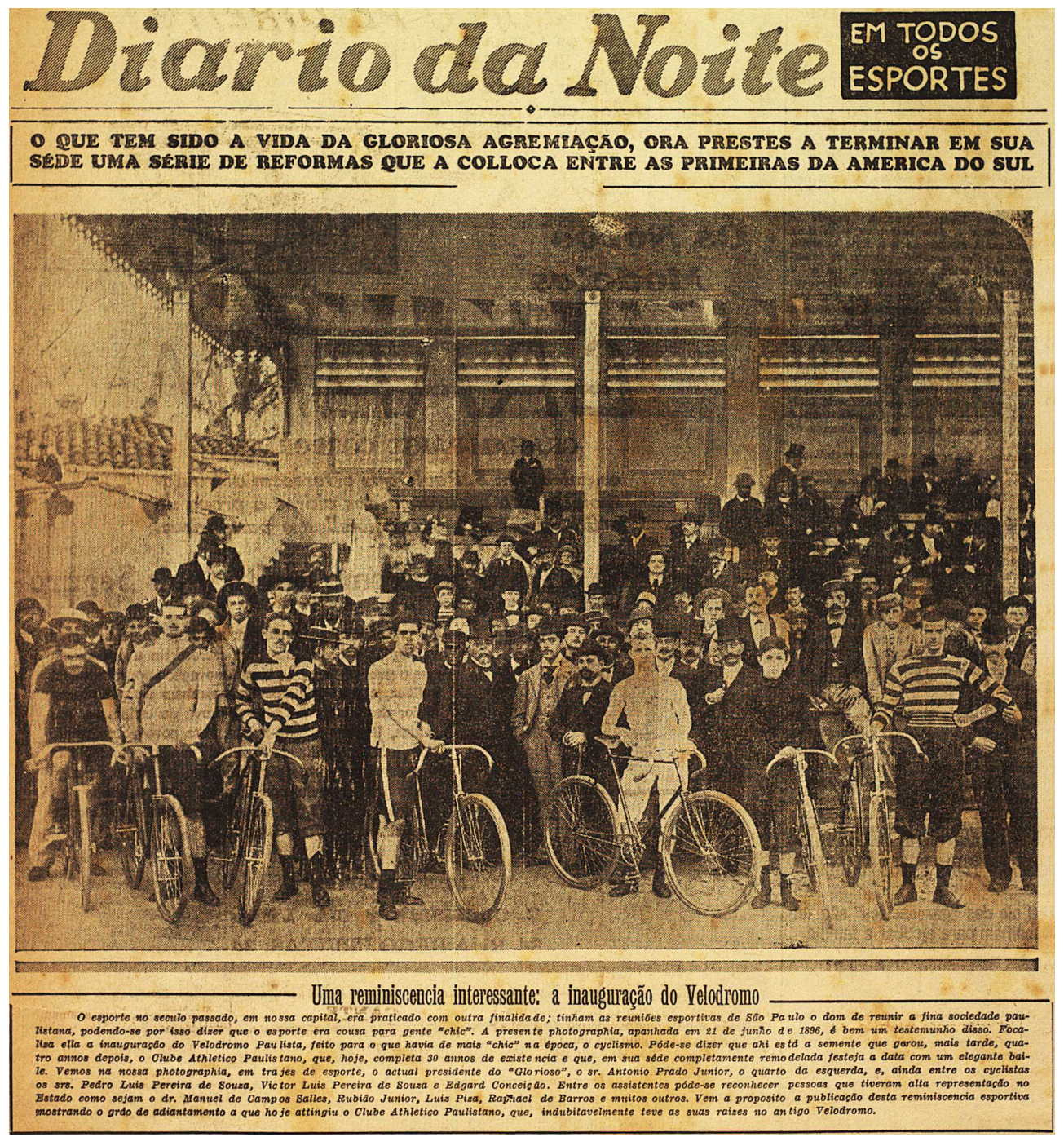

4. Capa do Diário da Noite. S/D. (Coleção Caio Prado Jr. - IEB - USP)

Ao mesmo tempo, dentro do contexto de intensas alterações nas estruturas sociais, políticas e econômicas no País, os grupos de elite e médios buscavam se 
distanciar dos grupos subalternos da cidade de São Paulo no início do século XX. Naquele momento, demarcar quem era quem era fundamental na visão desses grupos, pois as alterações promovidas pelo fim da escravidão e pela imigração abriam e ampliavam os espaços para a mobilidade social, algo impensável até então. Outra questão central para esses grupos se relacionava com o racismo e com o fato de a população brasileira ser constituída por negros, indígenas e mestiços de todos os tipos. A ideia de modernidade desses grupos implicava na construção de uma cidade que servisse de palco burguês e branco, palco em que os demais grupos ficassem escondidos ou fossem apagados dos referenciais oficiais.

O modelo excludente dos clubes e ligas oriundos do Reino Unido foi plenamente reproduzido pelos grupos dirigentes de São Paulo. Eric Hobsbawn chama a atenção para alguns aspectos importantes acerca das relações desses grupos com os esportes: a evidência de o futebol ser considerado elemento importante na formação das novas classes governantes latino-americanas, segundo o modelo do gentleman britânico burguês treinado em escola privada, ao discutir o papel das escolas ao introduzi-lo no continente; ${ }^{119}$ alguns dos futuros clubes profissionais de futebol eram times de firmas inglesas e de seus funcionários; o esporte apresentava um aspecto patriótico e até militarista; serviu, também, para criar novos padrões de vida e de coesão da classe média. $^{120}$

Essas elites e classes médias brasileiras que incorporavam os símbolos e práticas da modernidade precisavam transformar aquilo que vinha de fora em algo $s e u,{ }^{121} \mathrm{em}$ um discurso que legitimasse sua atuação como dirigentes, no momento em que questionamentos começavam a surgir acerca desse papel. Assim, a questão que se colocava era de como controlar esse processo modernizador, de forma a evitar a ascensão dos imigrantes e descendentes de escravos e o declínio de alguns abastados.

\footnotetext{
${ }^{119}$ SANTOS Neto, José Moraes dos. Visão do Jogo. Primórdios do futebol no Brasil. São Paulo, Cosac \& Naify, 2002. Págs.18 e 19. O autor afirma que o Colégio São Luís de Itu, apoiado no projeto de modernização escolar proposto por Rui Barbosa no início de 1882 e em viagens de seus professores e diretores à Europa, já adotava diversas modalidades esportivas como instrumentos pedagógicos, inclusive o futebol. Antonio Prado Jr., um dos fundadores do Paulistano e da Liga Paulista de Futebol seria prefeito do Rio de Janeiro nos anos 1920, por exemplo.

${ }^{120}$ HOBSBAWN, E. Op. Cit.. Págs. 256 e 257. O São Paulo Railway que teve seu nome alterado para Nacional em 1946, em decorrência do fim da concessão da Estrada de Ferro Santos-Jundiaí, disputou por muitos anos o campeonato paulista da primeira divisão.

${ }^{121}$ GONÇALVES, René Duarte Jr. Op. Cit. Pág. 51.
} 
Com o fim da escravidão e o estímulo governamental à imigração, a população da cidade de São Paulo se quadruplicou no espaço de dez anos, entre 1890 e $1900 .^{122}$ Essas mudanças demográficas e modernizadoras também eram acompanhadas por expectativas e esperanças de melhoria de condições de vida por parte daqueles que fugiam das fazendas de café e das memórias da escravidão, ou dos que chegavam oriundos de outros rincões do planeta. A realidade encontrada, no entanto, era bem diferente.

A remodelação urbana engendrada pela Prefeitura de São Paulo desde o final do século XIX apresentava características excludentes e racistas que obtiveram um êxito não encontrado em outras cidades brasileiras que passaram pelo mesmo processo naquele período. ${ }^{123} \mathrm{O}$ aparecimento de novos bairros destinados à burguesia e às classes médias no entorno do maciço da Avenida Paulista e nas proximidades das margens do rio Pinheiros, a ocupação das demais várzeas pela população mais pobre e o processo de especialização do centro que resultou na destruição do antigo patrimônio arquitetônico colonial e imperial faziam parte dessa dinâmica.

O êxito desse processo se relacionou com a incipiente urbanização de São Paulo por ocasião da Proclamação da República e o monopólio político exercido pelas elites junto à Prefeitura na defesa de seus interesses. Assim, o controle exercido pelos grupos dirigentes foi mais eficiente na construção e segregação dos bairros destinados aos diversos grupos sociais. O inchaço abrupto e insalubre vivido por São Paulo nas décadas posteriores não impediu o surgimento dessas áreas destinadas aos grupos abastados.

Para Raquel Rolnik, desenharam-se os fundamentos geográficos da cidade, dos quais não escapamos ainda hoje. ${ }^{124} \mathrm{Na}$ opinião da autora, as elites se utilizaram das leis como forma de garantir a proteção de seus espaços, funcionando como uma muralha

\footnotetext{
${ }^{122}$ MARINS, Paulo César Garcez. Habitação e vizinhança. Op. Cit. (In): SEVCENKO, Nicolau (org.) $O p$. Cit. Pág. 172. Segundo o autor, saltou de 64.934 para 239.820 habitantes.

${ }^{123}$ MARINS, Paulo César Garcez. Idem. (In): SEVCENKO, Nicolau (org.) Idem. Pág. 171.

${ }^{124}$ ROLNIK, Raquel. A cidade e a lei. Legislação, política urbana e territórios na cidade de São Paulo. Pág. 47. "Na Primeira República a imagem desta topografia social (dos bairros destinados à elite e construídos no espigão da Avenida Paulista) é feita de colinas secas, arejadas e iluminadas de palacetes que olha para as baixadas úmidas e pantanosas onde se aglomera a pobreza”. Na página 150, a autora descreve as dificuldades encontradas pelos habitantes de São Paulo para preencher os requisitos exigidos pela legislação eleitoral de 1891 para participar das eleições ou para se fazerem ouvir pela Prefeitura. O primeiro prefeito da cidade que teve que lidar com as pressões de um eleitorado um pouco mais democrático foi Jânio Quadros, eleito em 1953.
} 
invisível que segregava os espaços destinados aos pobres e aos ricos da cidade ${ }^{125}$. Mesmo assim, alguns bairros pobres coexistiam nas proximidades desses bairros luxuosos, como o bairro da Bela Vista, também conhecido como Bexiga, nas proximidades da Avenida Paulista, ou a Barra Funda, vizinha aos Campos Elíseos. ${ }^{126}$

Processo semelhante ocorreu nos espaços utilizados para o futebol. A despeito da proposta excludente dos clubes de elite, os pobres também praticavam o futebol em seus clubes e, algumas vezes, lado a lado com os ricos nos clubes desses, uma dinâmica que não é contemplada pela memória oficial do esporte. Além do mais, enchiam as improvisadas arquibancadas montadas na antiga pista de ciclismo do Velódromo ou de outras praças desportivas para assistir às partidas do campeonato paulista desde sua primeira edição, em 1902, ou a partidas amistosas organizadas por outras ligas.

A memória sobre o futebol paulistano no início do século XX consolidou uma narrativa em torno de ideias de elitismo e amadorismo relacionados aos entusiastas do futebol, que não corresponde ao que encontramos nas fontes, que nos sugerem aspectos um tanto diferentes, a despeito da capacidade de a elite paulistana legar sua memória pelos dos meios de comunicação e das dificuldades em encontrar publicações sobre os times de várzea. Dessa análise, podemos falar de um processo de construção de certa tradição elitista, ${ }^{127}$ que serviu para legitimar a atuação desses grupos como atores dirigentes do espetáculo quando o futebol começou a ganhar contornos de espetáculo de massa muito rentável, entre os anos de 1910 e 1920.

O futebol entusiasmava os jovens de todos os grupos sociais no início do século XX. Cabe compreender, agora, a que fim se destinava essa tradição elitista acerca do

\footnotetext{
${ }^{125}$ ROLNIK, Raquel. Op.Cit. Págs. 46 e 47.

126 ROLNIK, Raquel. Op.Cit. Págs. 76 e 77. Segundo a autora, a Barra Funda era o bairro mais caracterizadamente negro em São Paulo em decorrência de sua proximidade com a ferrovia, o que permitia aos homens obter algum rendimento ao trabalhar temporariamente como carregadores; a Bela Vista/Bexiga era um território negro que descendia de um quilombo dos tempos finais da escravidão. As moradoras dos dois bairros trabalhavam como empregadas nas casas abastadas dos bairros vizinhos. NEGREIROS, Plínio José Labriola de Campos. Op. Cit. Pág. 18. O autor afirma que o mesmo procedimento foi adotado com relação aos espaços desportivos da cidade, mas com êxito relativo e temporário.

${ }^{127}$ HOBSBAWN, Eric J. \& RANGER, Terence (orgs.). A invenção das tradições. Rio de Janeiro, Paz e Terra, 1997. Para uma discussão acerca dos procedimentos relativos às invenções de tradições. Para uma análise específica acerca do futebol brasileiro e invenções de tradições ver: HELAL, Ronaldo, LOVISOLO, Hugo, SOARES, Antonio Jorge. A invenção do país do futebol. Mídia, Raça e idolatria. Mauad, Rio de Janeiro, 2001.
} 
futebol e de que maneira o esporte foi adquirindo os contornos de espetáculo de massa que resultariam na profissionalização em 1933.

Para entendermos a construção do imaginário elitista e amador em torno do futebol, antes de qualquer coisa, é preciso retomar algumas considerações: a construção do Velódromo Paulista por D. Veridiana Prado, que além de agradar os desejos do neto ciclista - Antonio Prado Jr. -, tinha a pretensão que tinha de explorar o potencial econômico do espaço pela venda de ingressos e pelo estímulo às apostas, tal como ocorria no hipódromo, desta vez com as corridas de bicicletas; ${ }^{128}$ os donos de terreno estimulavam o uso desses espaços pelos times de várzea para os lotearem na sequência; ${ }^{129}$ os esportes ajudavam no aumento das tiragens e circulação dos periódicos, uma relação de cumplicidade que permitiu o aparecimento da crônica esportiva e o aumento da cobertura esportiva em todos os veículos de comunicação. ${ }^{130}$

Devemos levar em conta que as relações dos jogadores e times varzeanos com os times e jogadores do chamado futebol oficial se davam em um processo cheio de contradições, que variou da proibição à colaboração. Em alguns casos, quando os clubes tinham o acesso às maiores Ligas vedado, alguns jogadores eram convidados para atuar nos times que disputavam os campeonatos oficiais, como em 1915, quando os jogadores

\footnotetext{
${ }^{128}$ REIS FILHO, Nestor Goulart. Futebol e os velódromos. Jornal da Tarde, 09.06.1990, pág. 6.

${ }^{129}$ BOSI, Ecléa. Op. Cit. Pág. 138.

${ }^{130}$ MARQUES, José Carlos. O futebol em Nelson Rodrigues. O óbvio ululante, o Sobrenatural de Almeida e outros temas. São Paulo, EDUC/FAPESP, 2003. Pág. 17. Segundo o autor, " a invenção do profissional da crônica esportiva é simultânea a do próprio futebol profissional, donde temos uma múltipla simbiose: o jornal a criar a demanda para a produção do evento, e este o fornecer elementos para a atuação do homem da imprensa esportiva". Não é objeto central deste estudo a discussão acerca do papel dos meios de comunicação no processo de massificação dos esportes. No entanto, é preciso ressaltá-lo, pois ele continua existindo na atualidade e, durante o século XX, periódicos, emissoras de rádio e TV foram fundamentais nesse processo. Ver também: BRUHNS, Heloisa Turini. Futebol, carnaval e capoeira. Entre as gingas do corpo brasileiro. Campinas, Papirus, 2000. Pág. 62. MARTINBARBERO, J. Dos meios às mediações. Comunicação, cultura e hegemonia; Rio de Janeiro, UFRJ, 1997. SOARES, Edileuza. A bola no ar. O rádio esportivo em São Paulo. São Paulo, Summus, 1994. ANTUNES, Fátima Martin Rodrigues Ferreira. Com brasileiro não há quem possa! Futebol e identidade nacional em José Lins do Rego, Mário Filho e Nelson Rodrigues. São Paulo, Unesp, 2004. FRANZINI, Fábio. Op. Cit. TOLEDO, L. H. Lógicas no futebol. Dimensões Simbólicas de um Esporte Nacional. São Paulo, Tese de doutorado apresentada ao Dep. de Antropologia da FFLCH/USP, 2000. Acerca desse tema na Grã-Bretanha, verificar: TAW, Thomas. Football's Twelve Apostles. The making of the league (1886-1889). Desert Island Books, Southend - on - Sea, Essex, 2006.
} 
corintianos atuaram por outras equipes. ${ }^{131}$ Às vezes, jogavam ao mesmo tempo por equipes que atuavam em ligas diferentes.

A Liga Paulista de Futebol (Foot-ball) foi fundada em São Paulo, em dezembro de 1901. As dificuldades para sua criação, decorrentes da baixa adesão dos clubes existentes, exigiram a realização de várias reuniões. Desde o princípio, Antonio Casimiro da Costa, grande entusiasta da Liga, deixava claro suas intenções ao discutir com os colegas as estratégias para a organização da Liga Paulista de Futebol (LPF). Segundo Mazzoni,

"Entretanto "Costinha" aproveitou o momento para expor seus planos. Então, um dos companheiros o interpelou assim: "Mas, como vamos fundar isso e como havemos de manter essa Liga, com que dinheiro?" "Costinha" respondeu: "Com organização, passando a cobrar entradas nos campos e desse produto 50\% será para o clube e $50 \%$ para a Liga." 132

Os motivos para a organização da Liga Paulista de Futebol não estavam relacionados exclusivamente aos fatores de exclusão social. Podemos perceber que à segregação social se juntavam a questão econômica e a possibilidade de aferir lucros como preocupações dos fundadores da LPF. Foram necessárias três reuniões nas noites de 13, 14 e 19 de dezembro para que os envolvidos chegassem à formação da primeira diretoria. A organização do primeiro campeonato paulista a ser disputado em 1902 só se consumou no final de janeiro daquele ano, após reunião em que os clubes convidados a participar da fundação da Liga deveriam propor modificações nos estatutos apresentados nas reuniões de dezembro de 1901. ${ }^{133}$

Representantes de cinco clubes tomaram parte na fundação da Liga: Antonio Casimiro da Costa, W. Holland, Antonio S. Queiroz e Tancredo do Amaral, pelo

\footnotetext{
${ }^{131}$ BOSI, Ecléa. Op. Cit. O relato do Sr. Amadeu também é interessante por mostrar este processo pela atuação do $S$. C. Internacional que veio recrutar jogadores do time de várzea em que atuava para jogar na Primeira Divisão. Pág. 138. CITADINI, Antonio Roque. Neco. O primeiro ídolo. São Paulo, Geração, 2003. Pág. 60. Nota de rodapé n. ${ }^{\circ}$ 2. A informação consta originalmente de artigo escrito por MAZZONI, T. Espírito Varzeano. Amor Corinthiano. (In): Corinthians. Campeão dos Centenários. Álbum celebrativo publicado pelo clube, em 1964, com a colaboração de diversos autores. Disputaram o campeonato da APEA daquele ano por equipes "elitistas" os corintianos Amílcar, Fúlvio, Aparício e Perez pelo Ypiranga; Neco, Casemiro, Gonzales, César e Bianco pela A.A. Mackenzie College; e Police pelo Wanderers. Há dúvidas se Bororó atuou pelo Ypiranga naquela ocasião.

${ }^{132}$ MAZZONI, Thomas. Op. Cit. Pág. 28.

${ }^{133}$ Liga Paulista de Football. O Estado de S. Paulo. 20/12/1901. Pág. 2.
} 
Internacional; Charles Miller, H. J. Boyes e R. W. Crome, pelo São Paulo Athletic Club (SPAC); Artur Ravache, Ritter e H. Nobiling, pelo Germânia; Belfort Duarte, Alicio de Carvalho e Roberto Scholds, pelo Mackenzie; Otávio de Barros, Renato Miranda e João da Costa Marques, pelo Clube Atlético Paulistano. ${ }^{134}$

O pioneirismo na organização, os lucros aferidos pela venda de ingressos e a capacidade financeira dos sócios dos clubes envolvidos determinaram a denominação que se agregou a esse grupo: futebol oficial. Segundo os estatutos da Liga, em 1914, os clubes que participaram desse futebol oficial pagaram 200\$000 de joia para a LPF mais a contribuição anual de 50\$000, cada jogador inscrito por um clube gerava $1 \$ 000$ para a LPF, assim como a transferência de um jogador de uma equipe para outra rendia $25 \$ 000$ para a entidade. Por fim, a LPF tinha direito a $15 \%$ da renda bruta de toda partida disputada pelo campeonato. ${ }^{135}$

Durante o período estudado, as relações entre os clubes filiados não foram harmônicas, cordiais ou cavalheirescas. Ao longo dos anos, as brigas se sucederam na mesma medida em que nas disputas em campo, as rivalidades se estabeleciam e os interesses econômicos se ampliavam. As crises econômicas também atingiam as equipes do futebol oficial, da mesma forma que atingiam as equipes varzeanas e intensificavam as disputas entre as equipes.

Segundo Mazzoni, o primeiro grande conflito entre duas equipes do futebol oficial gerado em decorrência da mercantilização dentro dos espaços dedicados ao futebol e do potencial econômico gerado por essa prática ocorreu em 1906, quando a A.A. das Palmeiras foi acusada pelo Germânia de cobrar ingressos de maneira irregular para aqueles que quisessem assistir partidas de futebol em seu campo: ${ }^{136}$

"O fato causou alvoroço, chegando a constituir um caso de polícia, diante da atitude do grêmio da floresta (A.A. das Palmeiras) que invocou a intervenção do secretário de justiça, solicitando a abertura de um inquérito, que foi favorável ao Palmeiras (A.A. das Palmeiras)... Si houve um julgamento policial, a seu favor, o lado político não lhe sorriu, e a assembléia da Liga, diante do interesse de vários clubes, confirmou a punição do Palmeiras... Foi um caso complicado, em

\footnotetext{
${ }^{134}$ MAZZONI, Thomas. Op.Cit. Pág. 28

${ }^{135}$ Estatutos da Liga Paulista de Futebol, de 16/06/1914. Arquivo do Estado, C 10.415.452.

${ }^{136}$ MAZZONI, Thomas. Op.Cit. Pág. 61. Durante toda a primeira metade do século XX, estabeleceu-se a ideia de que os sócios dos clubes não precisariam pagar ingressos para assistir às partidas das respectivas equipes. SALUN, A. Op. Cit. Pág. 35.
} 
que cada um contava as cousas a seu modo, não se sabendo com quem estava a razão. Os "palmeiras" alegavam, em sua defesa, o seguinte: tinham um acordo com o Clube São Paulo de Regatas, que lhe cedia o campo (a Floresta), gratuitamente. As mensalidades, por isso, eram pagas a esse clube de canoagem. $\mathrm{Na}$ venda de entradas, os sócios do Palmeiras cediam-nas por $1 \$ 000$, a metade do preço. Mas os reclamantes diziam que era uma irregularidade sem nome, aduzindo vários aumentos."

As confusões e discordâncias entre as equipes se intensificavam e, por conta desse episódio, a A.A. das Palmeiras se afastou por dois anos dos Campeonatos Paulistas, voltando em 1909. Em 1911, as mesmas equipes protagonizaram outra confusão. No campeonato daquele ano, a A.A. das Palmeiras perdeu um jogo contra o Germânia, que utilizou jogador que não estava regularmente inscrito no campeonato. A derrota lhe custou o título daquele ano e a perda definitiva da primeira taça disputada em São Paulo para o SPAC.

As acusações de falso amadorismo (profissionalismo disfarçado de amadorismo) contra as equipes paulistanas do futebol oficial já existiam em 1912, quando o Americano (um time de Santos que disputava o campeonato em São Paulo) tomou a iniciativa de trazer dois irmãos jogadores oriundos do Uruguai exclusivamente para jogar futebol: A. Bertone e J. Bertone. ${ }^{137}$ Essa equipe tornou-se imbatível naquele ano, rivalizando-se com o Paulistano e sagrando-se campeã paulista.

Segundo Mazzoni, em 1917, a prática do falso amadorismo era corriqueira, decorrente do interesse dos clubes que disputavam o Campeonato Paulista de atrair os jogadores varzeanos em uma época em que o futebol de bairro vivia seu apogeu. A vitória era necessária, pois estimulava a presença do público nos campos, aumentava o número de simpatizantes de cada equipe e proporcionava melhores rendas aos clubes e à própria Liga. Os melhores jogadores eram remunerados então, inclusive Friedenreich pelo Paulistano. Em depoimento colhido por Salun, descobrimos que alguns clubes que atuavam na várzea também remuneravam seus atletas. ${ }^{138}$

"O interesse pelos clubes em atrair esses jogadores, o aumento extraordinário do público, a rivalidade, enfim, fizeram com que clubes e dirigentes começassem a colocar de lado certos escrúpulos na conquista de jogadores e, daí, dos empregos

\footnotetext{
${ }^{137}$ MAZZONI, Thomas. Op.Cit. Pág. 83.

${ }^{138}$ SALUN, A. O. Op. Cit. Pág. 155.
} 
passaram a dar propinas etc., e quanto aos prêmios, a cada vitória, sócios e diretores ofereciam objetos e até dinheiro." 139

A trapaça também passou a fazer parte do jogo, desde que os resultados aparecessem. Além do caso relatado do jogador irregular utilizado pelo Germânia em 1911, tivemos um escândalo protagonizado no campeonato de 1919 pela A. A. Mackenzie College, que atuou com um jogador que se utilizou de documentos falsos para substituir um jogador faltoso. ${ }^{140}$ Em 1932, na partida entre Palestra Itália e Corinthians, que definiu o campeonato daquele ano, houve a tentativa de suborno do jogador Jaú. ${ }^{141}$

O sonho que alguns dos pequenos times populares, ou de várzea, alimentavam de ingressar na Liga Paulista de Futebol, ou, a partir de 1913, com a cisão da Liga, na Associação Paulista dos Esportes Atléticos se relacionava com a possibilidade de obter lucros por meio do futebol. Nesse ano, alguns dos clubes excluídos da Liga Paulista de Futebol e da Associação Paulista de Esportes Atléticos fundaram uma outra liga: a Segunda Liga dos Esportes Atléticos, formada pelas equipes do Rio Branco, Argentino, Domitilla e Jaceguay. ${ }^{142}$

Durante muitos anos, a ruptura entre as equipes do futebol oficial de São Paulo que deu origem à Associação Paulista dos Esportes Atléticos, ${ }^{143}$ em 1913, foi fundamentalmente tratada como consequência do ingresso dos atletas de origem operária em alguns times que disputavam o Campeonato Paulista ou por conta do ingresso do Corinthians na Liga. Nos dizeres de Antonio Figueiredo:

\footnotetext{
${ }^{139}$ MAZZONI, Thomas. Op.Cit. Pág. 115.

${ }^{140}$ Notas de Sport. A Gazeta, 21/06/1919. A partida foi disputada no dia $1{ }^{\circ}$ de junho daquele ano entre Mackenzie e Minas Gerais. O jogador faltoso era José Benedicto, conhecido por Africano, que foi substituído por outro atleta. O periódico isentava o atleta de qualquer responsabilidade sobre o episódio, pois este informara com antecedência que não compareceria à partida. SALUN, A. Op. Cit. Pág. 26. Segundo o autor, a equipe do Mackenzie não exigia que seus jogadores fossem estudantes do Colégio desde o campeonato de 1912, quando a equipe reestreou no Campeonato Paulista.

${ }^{141}$ MAZZONI, T. Op. Cit. Pág. 235.

${ }^{142}$ Notas Sportivas. A Gazeta, 31/05/1913, Pág. 4. Outras ligas foram fundadas naquele contexto e seus nomes são recorrentes nos jornais da época. SALUN, A. Op. Cit. Pág. 34. Com base nas informações fornecidas por Lourenço DIAFÉRIA, o autor afirma que nos balancetes corintianos relativos aos meses de abril e junho de 1913, as rendas obtidas pelo clube com a venda de ingressos nas partidas de futebol eram superiores às obtidas com as mensalidades dos sócios. Em abril, as vendas de ingressos geraram $614 \$ 200$ enquanto as mensalidades geraram $116 \$ 000$. Em julho, as vendas de ingresso geraram $265 \$ 900$ e as mensalidades $226 \$ 000$.

143 APEA ou APSA, em decorrência de esporte ser grafado no original inglês.
} 
"Esse e outros incidentes deploráveis, que se tornaram comuns, originaram a formação de dois partidos no seio da Liga: um era favorável à seleção rigorosa, quer dizer, exigia que os quadros fossem constituídos de rapazes delicados e distintos; outros achavam que semelhante exclusivismo não era esportivo, porque tanto o rico como os pobres tinham direito a jogar... Os homens nunca chegaram a acordo satisfatório. Sendo assim, a cisão no seio da Liga Paulista de Futebol era fatal. Só faltava um pretexto." 144

A análise das fontes indica que a questão de fundo era outra: os lucros aferidos por meio dos campos de futebol utilizados pela Liga Paulista de Futebol e a escolha do Parque Antarctica como campo oficial da Liga, em detrimento do Velódromo Paulista. O aluguel cobrado pelo Paulistano para a utilização do Velódromo Paulista naquele ano foi considerado altíssimo por todos os membros da Liga. Enquanto o Germânia oferecia o Parque Antarctica para a Liga por 200 mil réis mensais, o Paulistano cobrava da entidade esse valor por jogo. ${ }^{145}$

Em um dos artigos do estatuto da LPF, constata-se que ela teria um campo que lhe pertenceria, algo que lhe permitiria escolher o campo a ser utilizado pelas equipes em uma partida, caso os dois adversários não entrassem em acordo sobre o local do jogo ou houvesse a necessidade de um jogo-desempate. Segundo o depoimento de dirigente do Paulistano naquela ocasião:

"É velha praxe em São Paulo - desde que se joga foot-ball - cada club ter o direito de escolher o campo, quando deve disputar um match; o próprio artigo 18 dos estatutos da Liga diz que haverá um campo pertencente à Liga e no qual serão disputados os matches, desde que não haja combinação mutual."

Ao contrário do que sugere Antonio Figueiredo, não era um mero pretexto, mas o problema principal por trás das disputas entre as equipes naquela ocasião. Tanto que após a fundação da APEA, todos os jogos do campeonato por ela organizado em 1913 ocorreram no Velódromo Paulista, independentemente de as equipes possuírem um

\footnotetext{
${ }^{144}$ MAZZONI, T. Op. Cit. Pág. 85. O autor se utiliza de trecho extraído da obra de FIGUEIREDO, A. História do Futebol em São Paulo. São Paulo, O Estado de S. Paulo, 1918, sem citar a página.

${ }^{145}$ MAZZONI, T. Op. Cit. Pág. 85.

${ }^{146}$ Chronica Sportiva. Correio Paulistano. 15/04/1913. Pág. 2. Carta enviada ao periódico por Adolpho Melchert Netto, dirigente do Paulistano.
} 
campo em boas condições. ${ }^{147}$ Segundo Ignácio de Loyola Brandão, a situação financeira do Paulistano naquela época não era confortável. Por exemplo, em 1915, o clube contava com apenas 15 sócios, ${ }^{148}$ o que nos permite inferir que as rendas do Velódromo eram muito importantes para o clube.

O estopim da cisão ocorreu por conta da segunda partida do Campeonato Paulista daquele ano disputada entre Paulistano e Americano, no Parque Antarctica, em 13 de abril de 1913. A partida e o local (Parque Antarctica) foram divulgados nos jornais pela LPF. Segundo o dirigente do Paulistano, as duas equipes haviam combinado que o jogo ocorreria no Velódromo Paulista, mas seu depoimento na mesma carta deixa antever a questão de outra maneira:

"Para terminar, devo dizer que a Liga andou mal communicando os jornaes que o jogo de hontem se realizaria no Parque Antarctica, pela razão muito simples de que no dia 12 mandei communicar ao presidente Sr. Lee, que o Club Athlético Paulistano só disputaria o match no Velódromo e não em qualquer outro campo." 149

Além do Club Athlético Paulistano, a A.A. Mackenzie College abandonou a Liga Paulista de Futebol. Juntos, convidaram a A.A. das Palmeiras, que se afastara da Liga Paulista de Futebol desde o conflito com o Germânia, em 1911. Em 1913, apenas essas três equipes disputaram o campeonato da APEA. Receberam, porém, o apoio público do Jockey Club de São Paulo, que ofertou a taça disputada pelas equipes, e, aos poucos, conseguiram esvaziar a Liga Paulista, que, em 1916, foi definitivamente unificada e submetida à APEA. Como primeiro presidente da nova Liga foi eleito Antonio Prado Jr. Um dos artigos do estatuto da APEA definia o Velódromo Paulista como campo oficial da nova entidade. ${ }^{150}$

${ }^{147}$ RIBEIRO, Rubens. O caminho da bola. 100 anos de história da Federação Paulista de Futebol. Volume I. Pág. 112. "A A.A. das Palmeiras, em respeito aos estatutos da APEA, disputava seus jogos no Velódromo apesar de possuir excelente "ground", que viria se tornar famoso anos depois". A ficha completa do campeonato organizado pela APEA é apresentada pelo autor na pág. 114.

${ }^{148}$ BRANDÃO, Ignácio de Loyola. Clube Atlético Paulistano. Pág. 23.

${ }^{149}$ Chronica Sportiva. Idem nota $n^{\circ}{ }^{145}$. O nome completo do dirigente não estava legível na cópia do Arquivo do Estado.

${ }^{150}$ Chronica Sportiva. Fundação de uma importante Sociedade Esportiva - APEA - Paulistano, Palmeiras e Mackenzie - A reunião de hontem - A aprovação dos estatutos. Correio Paulistano. 25/04/1913. Pág. 2. 
$\mathrm{O}$ argumento de que a inclusão do Corinthians foi o fator detonador da crise entre as equipes não se sustenta, pois o Paulistano tomou parte na organização do torneio de 1913, mesmo com o interesse da Liga em contar com o time do Bom Retiro, desde a abertura de uma vaga surgida com a saída do Internacional, no final de 1912. Além disso, o processo de seleção disputado contra outras três equipes realizado em 1913 foi definido algumas semanas antes do dissídio. A própria APEA convocava, em 1915, os jogadores corintianos para atuar ao lado dos jogadores do Paulistano na seleção paulista nos jogos contra as seleções cariocas. ${ }^{151}$

Assim, em 1913, Americano, Internacional, ${ }^{152}$ Ypiranga, Germânia e Corinthians disputaram o Campeonato Paulista organizado pela Liga Paulista de Futebol. Aliás, a ruptura foi uma oportunidade de ouro para outros times despontarem nas ligas, nos anos seguintes.

Cabe lembrar que, em 1910, processo semelhante fora adotado pela LPF, quando o Ypiranga quis ingressar na Liga e disputar o campeonato. Naquela ocasião, Ypiranga, Savoia e Vila Buarque disputaram o torneio seletivo. ${ }^{153}$ Santos Neto sugere que a desistência do SPAC naquela ocasião está relacionada com o ingresso do Ypiranga, time de comerciantes, fundado na então Rua Ypiranga (atual Av. Ipiranga), no centro de São Paulo. ${ }^{154} \mathrm{O}$ autor está equivocado, pois o SPAC atuou nos campeonatos da Liga até $1912 .{ }^{155}$ Também, não existem registros acerca de qualquer oposição da diretoria do Paulistano ao ingresso do Ypiranga na LPF.

A disputa entre as duas principais ligas foi marcada por lances pitorescos como o episódio em que a equipe italiana do Pro Vercelli se exibiu em São Paulo, a convite da APEA, como se fosse (inclusive usando o uniforme) a Seleção Italiana, em agosto de 1914. Na volta para a Itália, o clube e os jogadores foram punidos pela Federação Italiana, mas o êxito da partida foi enorme: 8.000 pessoas estiveram no Velódromo Paulista e a repercussão na cidade foi enorme. A ideia da excursão, preparada de maneira improvisada, sem grandes custos para a APEA, pois a equipe viera jogar no

\footnotetext{
${ }^{151}$ Il match per la Coppa Rio - São Paulo. Fanfulla. 03/09/1915. Pág. 5.

${ }^{152}$ MAZZONI, T. Op. Cit. Pág. O autor informa que a equipe do Internacional chegou a abandonar a Liga, voltando em seguida. No entanto, não informa os motivos.

${ }^{153}$ SALUN, A. O. Op. Cit. Pág. 54.

${ }^{154}$ SANTOS NETO, J.M. Op. Cit. Pág. 67.

155 RIBEIRO, R. Op. Cit. Págs. 100 e 101. As fichas das partidas disputadas pelo SPAC em 1912 estão disponíveis nas páginas citadas.
} 
Rio de Janeiro, era estragar a turnê de outra equipe italiana, o Torino, que visitava São Paulo naquele mês a convite da Liga Paulista de Futebol, que investira muito dinheiro na organização do evento, e causar grande prejuízo a esta entidade. ${ }^{156}$

Ainda no mesmo ano, a APEA estimulou a organização de um time de futebol formado por veteranos do Colégio São Bento, o Ginásio São Bento, causando um grande racha no principal time da Liga Paulista, o Americano. Formado majoritariamente por ex-alunos do colégio, o Americano perdeu muitos jogadores importantes para a nova equipe. Para piorar a situação da Liga Paulista, a deflagração da Primeira Guerra gerou grandes problemas financeiros para o Germânia nos anos seguintes. Seus dois principais times entraram em decadência técnica, diminuindo a qualidade do espetáculo, o interesse do público pelos jogos e as rendas que sustentavam a entidade.

Com a admissão do $\operatorname{Santos}^{157}$ e do Palestra Itália, em 1916, o campeonato apeano se destacou mais do que o campeonato da Liga Paulista, tanto no aspecto técnico quanto no econômico. Com o Palestra Itália no campeonato, a APEA teve um incremento de público e de renda notáveis para as partidas por ela organizadas. ${ }^{158}$ Ao mesmo tempo, diversas partidas do campeonato da Liga Paulista deixaram de ser realizadas por falta de organização e por problemas econômicos.

A sorte da Liga Paulista, finalmente, foi decidida nas relações diplomáticas com outras federações, em especial, na disputa para ver quem representaria o Brasil junto à FIFA, quem teria direito a organizar a Seleção Brasileira, a disputar torneios internacionais e a participar da fundação da Confederación Sudamericana de Football. Para tal, a Liga Paulista anunciou, em maio de 1915, a criação da Federação Brasileira de Futebol, recebendo, em agosto do mesmo ano, o reconhecimento da Associação Argentina de Futebol, que tinha o interesse em organizar um campeonato sul-americano que contasse com a participação brasileira.

\footnotetext{
${ }^{156}$ MAZZONI, T. Op. Cit. Págs. 95, 96 e 97. A disputa pelos amistosos internacionais foi apenas um dos capítulos dessa disputa e era importante pelo retorno financeiro, repercussão e prestígio que geravam. Segundo o autor, o declínio da Liga Paulista de Futebol começou a partir desse episódio.

${ }^{157}$ Chronicas Sportivas. Correio Paulistano. 9/05/1913. Pág. 2. O Santos foi aceito pela APEA em 1913, antes do primeiro campeonato organizado por esta Associação, mas não tomou parte dos primeiros torneios por motivos desconhecidos.

${ }^{158}$ ROLNIK, R. Op.Cit. Pag. 82. Segundo a autora, a imigração de italianos entre 1901 e 1920 trouxe 857.149 novos habitantes para a cidade, algo como 32,1\% dos habitantes em 1920.
} 
A iniciativa irritou os membros da APEA e da Liga Metropolitana de Sports Terrestres que se uniram em oposição à nova Federação criada pela Liga Paulista de Futebol. O apoio da APEA foi fundamental para que a iniciativa da Liga Metropolitana, entidade do Rio de Janeiro, de lançar a Federação Brasileira de Sport tivesse êxito. ${ }^{159}$ A partir de junho de 1916, essa Federação passou a se denominar Confederação Brasileira de Desportos, $\mathrm{CBD}$, e permitiu aos dirigentes e clubes da então capital do País controlar o futebol brasileiro, organizar a Seleção Brasileira e campeonatos oficiais, além de representar o país junto à FIFA. ${ }^{160}$

Com a unificação entre a Liga Paulista e a APEA no início de $1917,{ }^{161}$ apenas Corinthians e Internacional foram admitidos para a disputa do torneio principal organizado pela APEA naquele ano. As demais equipes deveriam participar da Segunda e Terceira divisões, inclusive o Americano, time de origem elitista que se envolvera no episódio deflagrador da cisão. Além disso, a dívida acumulada pela Liga Paulista de Futebol ficava a cargo exclusivo dos antigos diretores da Liga. ${ }^{162}$ Segundo Mazzoni,

\begin{abstract}
“O campeonato de 1917 assumiu em São Paulo extraordinárias proporções e isso em consequência da pacificação (...) Avulta em primeiro lugar pela sua importância o restabelecimento definitivo das nossas relações internacionais e o consequente reconhecimento pela Confederação Sulamericana de Futebol da entidade máxima dos esportes no Brasil, a Confederação Brasileira de Desportos, à qual somos filiados. Em segundo lugar, citamos o grande interesse
\end{abstract}

159 FRANZINI, Fábio. Op. Cit. Pág.19. Segundo Franzini, o acordo foi mediado pelo Ministro das Relações Exteriores Lauro Muller em 16 de novembro de 1915.

160 A confederação quer explorar os sócios do Fluminense. Inacreditável e inadmissível. A Gazeta, 09/05/1919. Por ocasião do Campeonato Sul-americano de futebol de 1919, realizado na cidade do Rio de Janeiro, os sócios do Fluminense, dono do campo utilizado durante o torneio, que tinham direito a usar a arquibancada reservada aos sócios, foram obrigados a se espremer na arquibancada geral, porque a CBD vendeu ingressos para os lugares que lhes pertenciam, originalmente. Foot-ball. O Estado de S. Paulo. 24/06/1918. Já naquela ocasião, o periódico anunciava a cobrança de ingressos para aqueles que quisessem assistir aos treinos da seleção brasileira.

161 O Estado de S. Paulo. 07/01/1917. Pág. 8. Segundo o periódico, a atuação do prefeito Washington Luis foi fundamental para por fim às disputas. O Estado de S. Paulo. 28/01/1917. Pág. 2. Ainda em 27/01/1917, a LPF não chegara a um consenso acerca do destino das equipes no torneio da APEA. $O$ Estado de S. Paulo. 06/02/1917. Apenas nessa ocasião, a APEA anunciou a classificação dos times da LPF e o Americano, como castigo, teve que disputar a Segunda Divisão. Naquela época, não existia descenso e acesso; os times da segunda divisão permaneciam nessa divisão, sem possibilidade de descer para a terceira ou subir para a primeira, assim como os da primeira não tinham como cair.

${ }^{162}$ MAZZONI, T. Op.Cit. Pág. 111. O autor apresenta todos os artigos do acordo. Provavelmente, Mário Cardim, dirigente da LPF arcou com suas dívidas. TOLEDO, L.H. O.p Cit. Pág. 43. Desde 1903, pela publicação de manuais e guias com regras de futebol, Cardim tentava disseminar a prática do futebol entre os moradores de São Paulo. 
pelos jogos do campeonato, manifestado pelo público paulistano que a eles correu sempre pressuroso, contribuindo assim para aumentar consideravelmente as rendas dos clubes, os quais por sua vez empregaram o máximo de seu esforço para corresponderem às simpatias que lhes foram dispensadas."

Entre 1917 e 1925, a hegemonia do Paulistano foi contestada por Palestra Itália ${ }^{164}$ e Corinthians. Os três times se transformaram nas grandes equipes do futebol paulistano, formaram o primeiro trio de ferro do futebol paulistano, disputaram os títulos, mobilizaram simpatizantes, criaram rivalidades e deflagraram uma nova cisão no final de 1925, quando o Paulistano se desligou da APEA e propôs a fundação da Liga Amadora de Futebol, LAF. Um pouco antes da cisão, ao regressar da Europa, o Paulistano incorporou em seu time dois jogadores que pertenciam ao São Bento, anteriormente, e que viajaram como reforços do Paulistano apenas para os amistosos disputados na Europa: Nestor e Barthô.

Uma das questões marcantes da LAF era o controle direto exercido pelos diretores sobre as rendas geradas pelos torneios. Não por acaso, mais uma vez, o nome escolhido para presidir a nova Liga foi o de Antonio Prado Jr. A perda do campeonato de 1925 para o São Bento, após partida tumultuada por conta da troca de equipes pelos jogadores Nestor e Barthô, foi a gota d'água para que o Paulistano deflagrasse a criação da nova Liga. Alguns dirigentes corintianos daquela época definiram a diretoria da LAF como uma ditadura.

Testemunhos editados em 1959 por duas revistas corintianas reproduziram o conteúdo discutido nas assembleias realizadas no clube, em junho e julho de 1927, que permitem entender o ambiente do futebol paulista dos anos 1920 e deixam entrever um embate entre Palestra Itália e Paulistano, para ver quem controlaria os destinos do futebol em São Paulo, com o Corinthians em um segundo plano. ${ }^{165}$ Além do mais,

\footnotetext{
${ }^{163}$ MAZZONI, T. Op. Cit. Pág. 113.

${ }^{164}$ MAZZONI, T. Palestra Itália. Pág. 8. O Palestra Itália chegou a abandonar a APEA em 1918, em decorrência do resultado de uma partida contra o Paulistano. Segundo os palestrinos, a atuação do juiz naquela ocasião foi determinante para que o Paulistano ganhasse o jogo. Os palestrinos fundaram, naquela ocasião, a Federação Olympica Paulista. Regressaram à APEA no ano seguinte.

${ }^{165}$ SALUN. Op. Cit. Pág. 68. O autor afirma que, em 1917, O Estado de S. Paulo promoveu um concurso entre seus leitores para descobrir quem os leitores escolheriam como dirigentes da APEA, já que, segundo o periódico, os bastidores do futebol já estavam corrompidos e deteriorados. Os votos dos leitores indicaram a preferência por Antonio Prado Júnior, dirigente do Paulistano, e Menotti Falchi, dirigente do Palestra Itália, indicando que os dois clubes gozavam de grande prestígio já naquela ocasião. Pág. 73.
} 
mostram como uma liga atuava para esvaziar a concorrente: prometendo benefícios como o acesso a campos para treinamento/jogo, prometida aos corintianos e a participação dos dirigentes de um clube na direção da entidade prometido aos dirigentes do São Bento. ${ }^{166}$

Em 1927, o Corinthians chegou a solicitar sua desfiliação da APEA, que, segundo os dirigentes corintianos, seria controlada pelo Palestra Itália, e o ingresso na LAF, controlada pelo Paulistano, mas, como o prometido pelos dirigentes da LAF não foi cumprido, a mudança causou um enorme prejuízo ao clube e o Corinthians ficou com condições humilhantes: voltar à APEA e apoiar o Palestra Itália ou se submeter aos caprichos da LAF e do Paulistano. ${ }^{167}$

O imaginário sobre a fundação da LAF gira em torno da ideia que se tratava de um processo de purificação do futebol de São Paulo, que estava contaminado pela prática do falso amadorismo. E alguns defensores do amadorismo eram os mesmos que defendiam a adoção de medidas que estimulassem a competição e o aperfeiçoamento técnico das equipes. Leopoldo Santanna, por exemplo, discutia a necessidade de instituir a ascensão e o descenso entre as equipes da primeira e da segunda divisão, em 1919, como estímulo às equipes, pois o péssimo desempenho técnico de algumas equipes afugentava o público das arquibancadas. ${ }^{168}$

$\mathrm{O}$ que as fontes sugerem acerca da LAF é diferente: o discurso sobre o amadorismo servia para encobrir o controle sobre a liga e os lucros gerados pelo

Segundo o autor, as relações entre Paulistano e Palestra Itália estavam estremecidas desde 1924. Naquela ocasião, os dirigentes palestrinos acusaram Antonio Prado Júnior de autoritário no periódico Fanfulla.

166 A mesma estratégia foi adotada em relação à LPF pelo Paulistano entre 1915 e 1916, quando o Germânia, Ypiranga e Wanderers abandonaram a LPF e ingressaram na APEA. O Corinthians tentou o mesmo caminho, mas foi barrado em 1915, ano em que seus jogadores atuaram por outras equipes.

${ }^{167}$ Memórias de um corinthiano. Revista do Corinthians n. ${ }^{\circ} 111$, de janeiro de 1959, págs. 9 e 24; e n. ${ }^{\circ}$ 112, de fevereiro de 1959, págs. 5, 8, 25 e 29. A coluna era publicada em diversas páginas dentro das revistas, sem assinatura. A direção da LAF era acusada pelos corintianos de ditatorial e desonesta. Os diretores afirmavam que o Corinthians não gozava de prestígio entre os membros da LAF, que vetaram o uso dos campos disponíveis para treinamento da equipe e não permitiam que membros do clube assumissem papéis diretivos na Liga. Na ocasião, metade do time do Corinthians fora suspensa após confusão gerada pela marcação de um pênalti a favor do Paulistano, em partida em que o Corinthians ganhava por 1x0. MAZZONI, T. Almanaque Esportivo de 1928. São Paulo, Ferrari \& Losasso Empreendimentos Gráficos, 1928. Pág. 219. A filiação corintiana à LAF ocorreu em 21 de fevereiro de 1927.

${ }^{168}$ A Gazeta, 23/07/1919, Pág. 2. No processo de fusão entre LPF e APEA, apenas dois clubes da LPF, Corinthians e Internacional, ingressaram no campeonato oficial da APEA. Os demais passaram a disputar um segundo campeonato, chamado de segunda divisão. Pelas regras da APEA, porém, os clubes da segunda divisão não disputariam de forma alguma o primeiro campeonato ou primeira divisão. 
futebol. Na segunda metade da década de 1920, os dirigentes do Palestra Itália contavam com grande número de simpatizantes, possuíam a melhor praça de esportes da cidade, o apoio da família Matarazzo e tinham plenas condições de se contraporem ao Paulistano. Mazzoni chega a afirmar que a cisão teria ocorrido após uma derrota, que condicionou a perda do campeonato para o São Bento, do Paulistano para o Palestra Itália, em 1925. Segundo Mazzoni, naquela ocasião metade da cidade tornou-se fúnebre, metade vibrou. ${ }^{169}$

Do ponto de vista das elites dirigentes paulistanas, o controle do espetáculo na cidade era apenas um dos problemas presentes naquelas décadas. Havia outros problemas sérios: o controle da CBD exercido pelos dirigentes do Fluminense; as rivalidades entre os clubes cariocas pelo controle da entidade máxima do futebol brasileiro, que, ao buscarem o apoio dos paulistas em suas demandas, fomentavam as cisões; e as próprias rivalidades entre paulistas e cariocas que foram estimuladas ao longo da década de 1920, por conta das convocações de jogadores para a seleção brasileira e das partidas disputadas entre as seleções estaduais. ${ }^{170}$

A ruptura da APEA, que deu origem à LAF, não permitiu ao Paulistano recuperar a primazia política no futebol de São Paulo tal como ocorrera com a ruptura da Liga Paulista de Futebol, que deu origem à APEA, porque clubes como Palestra Itália, Portuguesa, Santos e Corinthians já tinham prestígio político e econômico para se contraporem a ele. A cisão, como todas as outras cisões, enfraqueceu, como um todo, o futebol oficial em São Paulo ao diminuir a lucratividade dos jogos e campeonatos, gerou

${ }^{169}$ MAZZONI, T. Op. Cit. Pág. 190. As fontes são conflitantes, pois O Estado de S. Paulo afirma que a derrota ocorreu para o São Bento. Um grande prejuízo para São Paulo. O Estado de S. Paulo, 03/11/1925, Pág. 6.

170 Ainda o facto da CBD ter recusado o concurso dos paulistas ao campeonato mundial. A Gazeta Esportiva, 16/06/1930, Pág. 4. Episódios que foram recorrentes durante a década de 1920. Leopoldo Santanna foi o correspondente do periódico A Gazeta no Rio de Janeiro por ocasião do Campeonato SulAmericano de futebol. Desde então, suas colunas se caracterizaram pela virulência com que denunciava o bairrismo da CBD, que, segundo ele, beneficiou os times do Rio de Janeiro. Ver: As mazellas do sport. Importante sessão da CBD. Neco no Fluminense? Sport. A Gazeta, 15/08/1919, Pág. 2. Nas reuniões da CBD, a APEA sempre terá contra si "votos de uma maioria deliberadamente hostil". Notas de Sport. $A$ Gazeta, 22/08/1919, Pág. 2. FRANZINI, Fábio. Op. Cit. Págs. 19 e 22. Franzini afirma que os atritos entre os dois grupos faziam parte de uma luta maior, travada no campo ideológico por grupos empenhados em conquistar a hegemonia cultural e política no País. Pereira foca sua análise na questão da formação das identidades regionais, consideradas quase raças pelos envolvidos nas polêmicas, durante a década de 1920. PEREIRA, Leonardo. Footballmania. Uma História Social do Futebol no Rio de Janeiro (1902-1938). Rio de Janeiro, Nova Fronteira, 2000. 
prejuízos para os envolvidos, levou diversos clubes à falência, ${ }^{171}$ em especial os que seguiram o Paulistano na LAF, e quase se transformou em tragédia com cenas de vandalismo explícito, em 1927, quando o Parque Antarctica foi depredado pelo público durante uma partida amistosa promovida pela Associação Paulista dos Cronistas após o Campeonato Brasileiro daquele ano.

A partida deveria ser uma festividade disputada entre o selecionado carioca e o paulista. Como quase todos os jogadores cariocas não embarcaram para São Paulo, estimulados por seus dirigentes, os organizadores da partida em vez de a cancelarem e arcarem com os prejuízos, preencheram a equipe carioca com jogadores das equipes da Segunda Divisão de São Paulo, que foram prontamente reconhecidos pelos que pagaram ingresso, e o campo estava lotado. Revoltada, a torcida destruiu tudo que encontrou no Parque Antarctica e tentou assaltar a sede da Associação. ${ }^{172}$ O Palestra Itália demorou alguns meses para lançar o projeto de um estádio, fazendo-o em março de $1929 .{ }^{173}$

Possivelmente, a percepção de que o controle da entidade máxima do futebol brasileiro estava perdido e de que o fortalecimento das equipes de origem popular ameaçava o controle das entidades paulistas fez com que alguns simpatizantes dos clubes da elite paulistana criassem uma genealogia do esporte, por meio da figura de Miller, a partir de 1918, que permitisse questionar a hegemonia carioca, construísse um imaginário em torno da existência de grandes e suntuosos estádios que legitimavam a ideia da cidade de São Paulo como a metrópole sul-americana desse esporte, ${ }^{174} \mathrm{e}$ fundaram um passado elitista e sofisticado nos clubes e praticantes que lhes assegurasse ou, pelo menos, legitimasse o controle do futebol paulistano. Ao mesmo tempo, esse

\footnotetext{
${ }^{171}$ Retornando... Augusto Castro Leite, $2{ }^{\circ}$ thesoureiro da A.A. Palmeiras, volta á atividade esportiva - O que s.s. nos contou sobre o tradicional núcleo da Floresta. A Gazeta Esportiva, 24/11/1929, Pág.15. Em entrevista ao jornal, Augusto Leite, dirigente da A.A. das Palmeiras, fala da situação financeira caótica vivida pelo clube e a existência do risco de desaparecimento do clube. A cisão de 1913 também trouxe sérios prejuízos ao Paulistano, que chegou a pensar em abandonar a prática de futebol no início de 1915. Club Athletico Paulistano. 18. ${ }^{\circ}$ Anniversário. O Estado de S. Paulo, 19/12/1918, Pág. 5.

${ }^{172}$ MAZZONI, T. História do Futebol no Brasil. Op. Cit. Pág. 203.

${ }^{173}$ Característicos do estádio projetado pelo Palestra. A Gazeta Esportiva, 11/03/1929, Pág.7. MAZZONI, T. Idem. Pág. 241. O estádio foi reinaugurado parcialmente, em 1933, com capacidade para 30 mil espectadores. Segundo o autor, a primeira partida profissional disputada no Brasil foi entre São Paulo e Corinthians e gerou a renda de 42 contos de réis.

${ }^{174}$ O Club Athlético Ypiranga commemora hoje o seu 13. ${ }^{\circ}$ terceiro anniversário. Sport. A Gazeta, 10/07/1919, Pág.2. "Bem entre os bons é elle um dos que mais têm trabalhado pelo football em São Paulo, a metrópole sula-mericana desse sport."
} 
passado mítico cheio de contradições apagava os vestígios da participação de diversos grupos sociais no processo que ressignificou o futebol para a sociedade paulistana.

\subsection{O papel de negros e descendentes de imigrantes no processo de ressignificação do futebol paulistano.}

"Não era uma cidade nem de negros, nem de brancos e nem de mestiços; nem de estrangeiros e nem de brasileiros; nem americana, nem européia, nem nativa; nem era industrial, apesar do volume crescente das fábricas, nem entreposto agrícola, apesar da importância crucial do café; não era tropical, nem subtropical; não era ainda moderna, mas já não tinha passado." ${ }^{175}$

"Realisa-se hoje no Velódromo Paulista, uma attraente festa sportiva em benefício do hospital das crianças Cruz Vermelha. Foi organisado um interessante match de foot-ball, no qual os guapos rapazes do Sport Club Americano preparam magníficas surpresas. Esse match será jogado entre um team de senhoritas e outro de rapazes." 176

A mercantilização em torno do futebol praticado nas Ligas e suas crises não impediram o desenvolvimento do esporte de maneira desinteressada, lúdica ou amadora nos múltiplos clubes da cidade, simultaneamente. Ao lado do futebol-negócio, convivia o futebol como atividade de lazer. A adesão ao futebol se multiplicava em relação à sua prática, fosse ela amadora ou profissional disfarçada de falso amadorismo ou ainda como fator identitário, mesmo entre aqueles que não jogavam futebol, em todos os grupos sociais.

Em janeiro de 1919, O Estado de S. Paulo informava que o progresso dos esportes em São Paulo naquele ano também se relacionava, dentre vários motivos, com o aparecimento de livros que tratavam dos esportes de um ponto de vista "brasileiro":

"Outro signal indicativo do nosso progresso em cultura physica é que começamos a ter uma bibliografia sportiva. Até bem recentemente, exceptuando os óptimos guias annuários paulistas cuja publicação foi aqui iniciada e durante longo tempo

\footnotetext{
175 SEVCENKO, N. Orfeu extático na metrópole. São Paulo, Sociedade e Cultura nos Frementes Anos 1920. Pág. 31.

${ }^{176}$ Notas Sportivas. A Gazeta. 25/01/1913. Capa do jornal. A mesma nota aparece na mesma data em outros jornais consultados como Correio Paulistano e $O$ Estado de S. Paulo.
} 
mantida pelo Dr. Marin Cardim, quase nenhum livro havia no Brasil que tratasse dos sports, entre nós, de um ponto de vista brasileiro"177.

Foram publicadas as obras Resumo histórico do Club Athlético Paulistano, de autor não identificado, História do Foot-ball em São Paulo e O Football em São Paulo. Notas Critico-Biographicas dos Principaes Jogadores Paulistas. Antigos $e$ Modernos. ${ }^{178}$ As duas últimas ocuparam espaço importante no processo de construção do imaginário elitista em torno do futebol, que, desde então, é repetido pelos cronistas e estudiosos do assunto.

Em janeiro de 1919, o mesmo periódico ajudava a promover um concurso organizado pela Cruz Vermelha Americana com o intuito de arrecadar fundos para a instituição. O concurso valia até o dia 15 de janeiro daquele ano e se realizava pela compra de bilhetes de tômbola, vendidos na Praça Antonio Prado, que custavam mil réis. Eram oferecidos seis prêmios de 35 contos. Além de participarem do sorteio, aqueles que compravam o bilhete podiam indicar o time de sua preferência, uma tentativa de o periódico averiguar a popularidade das equipes que disputavam o Campeonato Paulista.

O concurso causou reboliço nas rodas futebolísticas da cidade na mesma medida que a suspensão de Friedenreich, Amílcar e Neco ou a expulsão da APEA da CBD. Em algumas ocasiões, o periódico chegou a pedir que os clubes não restringissem o acesso aos boletos e permitissem que os interessados votassem. ${ }^{179}$ Os resultados foram os seguintes: $1 .^{\circ}$ lugar - Paulistano, com mais de 68 mil votos; $2 .^{\circ}$ lugar - Palestra Itália, com mais de 33 mil votos; $3 .^{\circ}$ lugar - A. A. das Palmeiras, com mais de 8 mil votos; . $^{\circ}$ lugar - Ypiranga, com mais de 5.400 votos; $5 .^{\circ}$ lugar - São Bento, com cerca de 5 mil votos; 6. ${ }^{\circ}$ lugar - Santos, com mais de 4.700 votos; $7 .^{\circ}$ lugar - Corinthians, com mais de

\footnotetext{
${ }^{177}$ O anno sportivo. O Estado de S. Paulo. 01/01/1919. Pág. 5.

${ }^{178}$ FIGUEIREDO, A. Op. Cit.; SANTANNA, L. O Football em São Paulo. Notas Critico-Biographicas dos Principaes Jogadores Paulistas. Antigos e Modernos. São Paulo, Typographia Piratininga, 1918

${ }^{179}$ Concurso promovido pela Cruz Vermelha norte-americana. O Estado de S. Paulo. 04/01/1919. Pág. 5. Pelas fontes, alguns clubes tentaram utilizar o poderio econômico para distribuir boletos entre seus associados e influir no resultado final da apuração. De qualquer forma, ficou evidente a hegemonia política e econômica do Paulistano e a ascensão do Palestra Itália como segunda força do futebol de São Paulo.
} 
3.400 votos; $8 .^{\circ}$ lugar - Mackenzie, com mais de 1.200 votos; 9..$^{\circ}$ lugar - Minas Gerais, com 989; $10 .^{\circ}$ lugar - Internacional, com $702 \operatorname{votos}^{180}$.

O envolvimento da população com o concurso mostrava o quanto o futebol poderia ser lucrativo para aqueles que o controlavam e, o que era mais importante, mobilizou boa parte da população da cidade. A população de São Paulo estava em torno de 500 mil habitantes e foram vendidos mais de 100 mil bilhetes de tômbola. O potencial econômico do esporte era explícito no final da década de 1910 e plenamente explorado na década de 1920, como atesta Leopoldo Santanna, que, àquela época, era um defensor do amadorismo no futebol. Seu segundo livro, publicado em 1925, contou com publicidade em várias páginas. ${ }^{181}$ Nessa obra, ao criticar a prática do falso amadorismo, mostrava como os clubes oficiais arregimentavam jogadores na várzea por intermédio de emissários e os tratavam como capital-dinheiro. ${ }^{182}$ Por fim, apresentou um interessante relato de como a mercantilização crescente afastava alguns e aproximava outros dos cargos de diretores de clubes. ${ }^{183}$

No artigo publicado no periódico $O$ Estado de $S$. Paulo no dia 1..$^{\circ}$ de janeiro de 1919, transparecem discussões importantes e atuais: O que era o futebol dentro de um ponto de vista brasileiro? Por que o periódico se preocupa com essa questão em 1919? Como explicar a ressignificação de uma prática estrangeira a ponto de transformá-la em símbolo de nacionalidade? Como práticas culturais estrangeiras foram ressignificadas pela população brasileira? Pensando nas sugestões de Damatta, não estava em curso um

\footnotetext{
${ }^{180}$ Resultado final. O Estado de S. Paulo. 18/01/1919. Pág. 6. A população da cidade segundo o censo de 1920 era de 579.033 habitantes. SALUN, A. Op. Cit. Pág. 70. O autor apresenta uma tabela com o número de sócios que cada equipe possuía entre as décadas de 1910 e 1930. Em 1919, por exemplo, o Paulistano possuía 1.149 sócios, contra apenas 15, em 1915; o Corinthians possuía, em 1916, apenas 59 sócios; o Palestra Itália possuía 75 sócios, em 1917.

Fonte: http://sempla.prefeitura.sp.gov.br/historico/tabelas/pop_brasil.php.

${ }^{181}$ SANTANNA, Leopoldo. Op. Cit. Encontramos anúncios de lojas de materiais esportivos, advogados, médicos, tipografias, perfumarias, automóveis, joalherias, entre outros.

${ }^{182} \mathrm{O}$ investimento realizado pelos empresários era o pagamento de salários ou parcos benefícios aos atletas em um período em que não havia qualquer regulamentação profissional em todas as áreas da economia brasileira e os trabalhadores eram submetidos a regimes de trabalho extremamente precários, inclusive no futebol.

${ }^{183}$ SANTANNA, Leopoldo. Op. Cit. Pág. 156. "Assim, os cargos de directores de clubes são verdadeiros postos de sacrifício...monetário. Delles fogem, pois, aquelles que se não amoldam a situações amoraes e que não estão dispostos a concorrer para o sustento fácil de...malandros". Ainda na pág. 158, o autor diz que "esses indivíduos, nas assembléas, nas commissões, e na propria directoria dos clubes e da maxima entidade, apenas procuram defender interesses subalternos e privados, deixando aos azares da sorte os altos interesses da collectividade".
} 
processo de deslocamento ou de passagem ${ }^{184}$ do futebol que resultaria em uma nova simbolização das práticas esportivas na cidade? Ou será que o processo de deslocamento não estava consolidado naquela ocasião?

Alguns autores que estudam o futebol tendem a pensar que apenas naquele momento, final da década de 1910, o processo de ressignificação estava começando ou, na melhor das hipóteses, acontecendo. Tratar-se-ia do processo de popularização do futebol, que, de esporte elitista, converter-se-ia em prática popular. Outros chegam a falar na descoberta do futebol pelos brasileiros como consequência do Campeonato SulAmericano de 1919. ${ }^{185}$

Podemos pensar, porém, que, então, o futebol fora apropriado por todos os segmentos sociais, sofrendo um processo de ressignificação por parte da população paulistana, talvez brasileira como um todo, e, aos poucos, se transformava em uma atividade diferenciada, ritualizada. ${ }^{186} \mathrm{Na}$ prática, os diversos grupos envolvidos nas atividades do futebol, fossem de elite ou pobres, imigrantes ou nacionais, brancos, negros ou mestiços, naquela ocasião, tentavam demarcar quem era quem nos novos espaços que adquiriam as características de espaços ritualísticos. ${ }^{187}$

184 DAMATTA, Roberto. Op. Cit. Págs. 97 e 98. Nesta obra, o autor sugere que o processo de simbolização só ocorre quando há o deslocamento ou passagem de um elemento, objeto ou papel social de um domínio de origem para outro, quando este elemento torna-se responsável por uma série de processos que podem ser percebidos como invertidos, reforçados ou mesmo neutralizados.

${ }^{185}$ SANDER, R. Sul-Americano de 1919. Quando o Brasil descobriu o futebol. São Paulo, Maquinaria Editorial, 2009. Indica que o futebol se populariza a partir da conquista do título de 1919. FRANZINI, F. Op. Cit. Sugere que, a partir de 1919, ocorre uma aproximação entre futebol e identidade nacional que resultou no discurso varguista das décadas de 1930 e 1940.

${ }^{186}$ DAMATTA, Roberto. Op. Cit. Pág. 99. Para ele, os atos de simbolizar e ritualizar caminham sempre juntos e são fenômenos que trazem à tona a consciência da natureza do objeto, das propriedades do seu domínio de origem e da adequação ou não do seu novo local. Nas páginas 47, 48 e 49, descreve os ritos como acontecimentos extraordinários na vida de determinada sociedade, eventos que abarcam todos os segmentos sociais, indistintamente, dentro de um contexto de confrontação entre pessoas, grupos ou categorias, daí a utilização do termo dramatização, conforme pág. 207. Na batucada da vida. Samba e política no Rio de Janeiro (1889-1930). Tese de doutorado apresentada ao programa de pós-graduação em Antropologia Social da USP, 1999. Pág. III. A autora propõe a existência, dentro da sociedade brasileira, de uma certa disposição por parte tanto das classes subalternas, quanto das classes dirigentes de atenuar os conflitos, o que os obriga a um reposicionamento constante.

${ }^{187}$ DAMATTA, Roberto. Op. Cit. Pág. 100. Segundo o autor, nas sociedades complexas, a existência de diversos polos que competem entre si leva à criação de diversos movimentos e passagens. Alguns desses movimentos e passagens adquirem importância e são convertidos em rituais. Conforme pág. 102. Ele compara o ato ritualístico à encenação de uma peça de teatro, um drama, em que os conflitos entre os grupos sociais e os papéis de cada um deles são plenamente conhecidos por todos os envolvidos na dramatização. Cf. pág. 254. 
Em sociedades complexas como a paulistana, a existência de diversos polos identitários ou domínios sociais, bairros, comunidades, classes sociais, grupos étnicos e nacionais que competiam, e alguns ainda competem entre si, levou à criação de diversos movimentos e passagens em que os conflitos eram recorrentes. Alguns desses movimentos e passagens adquiriram importância e se converteram em rituais, em espaços privilegiados de mediação nos quais os grupos envolvidos disputaram prestígio, dinheiro e espaço. As fontes sugerem ser esse o caso do futebol; não por acaso, já naquele ano, a Prefeitura projetava a construção de um estádio municipal. A questão que se colocava para as elites paulistanas era o de legitimar o exercício de poder nesses espaços pela criação de uma genealogia ou da invenção de certa tradição elitista que determinasse e classificasse o papel dos grupos sociais.

Algumas situações como a divulgada pelo Club Athlético Paulistano, em 1918, contradizem amplamente o imaginário construído em torno dele, de seus associados e da popularização do futebol em São Paulo:

"Podemos nos gabar sem receio algum, de termos concorrido, para o desenvolvimento do futebol em São Paulo...foi o Paulistano que popularizou o futebol, popularizou é bem o termo, porque antes dele nenhum clube resolvera fazer propaganda. Os primeiros sócios eram efetivamente escandalosos e queriam provocar a atenção de todos. E não se poupavam. Um domingo qualquer reuniamse vários rapazes, pertencentes ao clube e partiam nos bondes, por essas vias públicas afora. A algazarra era grande, todo mundo vinha à porta, para saber do que se tratava...apesar de serem filhos das melhores famílias...chamar a atenção do povo, era o melhor comercial e o mais poderoso estímulo...Hoje, se reconhece o papel do povo no desenvolvimento do esporte: é o elemento indispensável para a prosperidade do clube." 188

$\mathrm{Ou}$ a descrição apresentada no Correio Paulistano sobre a torcida que acompanhava um jogo entre Corinthians e Internacional, no Parque Antarctica, em maio de 1914: "Essa disputa ansiosamente esperada, levou às arquibancadas do ground do Parque Antarctica uma assistência considerável e selecta." 189

Dentro de um contexto marcado por conflitos sociais de diversas ordens e de reordenamentos espaciais, a apropriação de uma prática estrangeira, como o futebol, por todos os segmentos sociais paulistanos implicou a construção de um espaço propício às

\footnotetext{
${ }^{188}$ SALUN, A. Palestra Itália e Corinthians. Quinta Coluna ou Tudo Buona Gente?Op. Cit. Pág. 50.

${ }^{189}$ Chrônica Sportiva. Correio Paulistano. 11/05/1914. Pág. 3.
} 
negociações transculturais que traziam conseqüências muitas vezes antagônicas. Em alguns casos, essas negociações enfatizavam as diferenças entre os praticantes em discursos heterogêneos; em outros, enfatizavam o que existia em comum, por meio de discursos homogêneos. ${ }^{190} \mathrm{O}$ discurso praticado pelos grupos elitistas de São Paulo através dessas genealogias apagou a existência dessas negociações e consolidou uma narrativa de que o futebol era uma prática exclusiva das elites, aberta, aos poucos, aos grupos populares sem qualquer tipo de conflito, tal como denuncia Franzini, razão pela qual os grupos populares deveriam se subordinar ao comando dos pais e introdutores do futebol.

Seguindo essa lógica, a existência de espaços específicos utilizados pelos diversos grupos sociais para a prática do futebol em São Paulo na década de 1910 nos leva a discutir o papel desempenhado por alguns praticantes dentro de um processo que permitiu a fusão do futebol oficial com o futebol varzeano, até então profundamente distantes um do outro nas décadas de 1910 e 1920. Nessa perspectiva, alguns jogadores atuaram como intermediários ou mediadores culturais ${ }^{191}$ e conseguiram transitar nos dois espaços, como Charles Miller ${ }^{192}$ e Arthur Friedenreich. ${ }^{193}$

${ }^{190}$ VIANNA, Hermano. O mistério do Samba. Rio de Janeiro, Jorge Zahar, 1995. Págs. 153 e 154. REIS, L.V.S. Op. Cit. Págs. 19, 20 e 29. Ela afirma, ao discutir o samba e as religiões afro-brasileiras no Rio de Janeiro, que não há oposição absoluta entre os personagens da trama, existindo uma promiscuidade entre os domínios da ordem e da desordem. O exemplo que apresenta se relaciona com os principais políticos da Primeira República, que, enquanto reprimiam publicamente práticas afro-brasileiras, recebiam em seus palácios mães de santo, sambistas e chorões. E havia a tendência entre acomodação e resistência entre os grupos negros, diante da repressão. DAMATTA, R. Carnavais, Malandros e Heróis. Para uma sociologia do dilema brasileiro. Op. Cit. Pág. 193. Afirma ainda que, em sociedades com possibilidades de classificações sociais baseadas em múltiplos eixos, não surgem apenas rituais compensatórios para desigualdades, mas, também, rituais que demarcam as diferenças entre aqueles que, aparentemente, são iguais.

191 VIANNA, Hermano. Op. Cit. Pág. 52. O termo foi extraído do texto sobre o papel do samba na construção da identidade brasileira, em que o autor afirma que "pode ser pensado melhor, não como um conciliador ou criador de sínteses culturais, mas como um mediador no sentido de colocar em contato mundos culturais bem diversos ou, pelo menos, de transitar por vários mundos, deixando suas marcas em cada um deles, nem que fosse a marca de torná-los expostos ao que vem de fora". Adiante, na pág. 122, complementa: "A antropologia da vida em grandes metrópoles já nos ensinou que fenômenos culturais diversos podem existir lado a lado sem que se estabeleça nenhum contato entre eles. A curiosidade é necessária para que membros de um grupo passem a freqüentar outros grupos, transformando-se naquilo que estou chamando de mediadores transculturais". Quanto ao futebol, a pesquisa de GONÇALVES, René Duarte Jr. Fridenreich e a reinvenção de São Paulo. O futebol e a vitória na fundação da metrópole. discute o papel de Friedenreich como mediador cultural entre os dois espaços de futebol da cidade.

192 MILLS, John R. Charles William Miller. Memoriam SPAC.1894-1994. São Paulo, Price Waterhouse, 1996. Para uma melhor compreensão da trajetória de Charles Miller. 
No entanto, a análise nos leva a discutir o tema em perspectiva um pouco diferente, dentro da linha de pensamento apresentada por Seabra ${ }^{194}$ e Damatta, ${ }^{195}$ ao proporem a primeira como o convívio dialético entre amadorismo e profissionalismo, na trajetória do futebol em São Paulo, e a segunda como a formação de núcleos de parentescos dentro dos padrões sociais pré-abolição da escravidão nas associações populares surgidas no Brasil durante o século XX, dentre elas, os clubes de futebol e as escolas de samba que conviviam com a ideologia igualitária ou liberal burguesa.

O desenvolvimento das atividades dos clubes de futebol e a ampliação do número de simpatizantes também criaram movimentos dialéticos ou mesmo antagônicos dentro das próprias associações. Nos clubes elitistas, surgiram grupos profundamente interessados no desenvolvimento das atividades competitivas do futebol que se relacionavam com sua profissionalização e especialização, algo que implicava a perda do exclusivismo social que caracterizava esses clubes e a abertura para outros segmentos sociais. Outros grupos se contrapunham a qualquer iniciativa nesse sentido e mantinham suas atividades amadoras e excludentes. Acreditamos que foi o caso do Paulistano, que abandonou o futebol oficial em 1929. Quando os grupos que advogavam o exclusivismo triunfaram e obrigaram o fechamento do departamento de futebol, causaram a debandada de dirigentes e atletas, que tomaram a iniciativa de fundar um novo clube: o São Paulo Futebol Clube.

Nos clubes populares, de origem varzeana ou de bairro, que desenvolviam o futebol profissional ou falsamente amador, as atividades verdadeiramente amadoras eram mantidas em paralelo às profissionais e serviam para fornecer os novos atletas e simpatizantes, que eram fundamentais para a manutenção das cada vez mais dispendiosas, embora muito lucrativas, atividades competitivas e profissionais do futebol. Nessa fase, empresários controlavam as diretorias das principais equipes do futebol de São Paulo e as comandavam quase como propriedades particulares. Os clubes

\footnotetext{
193 GONÇALVES Jr, René Duarte. Op. Cit.

${ }^{194}$ SEABRA. O. C. L. Urbanização e fragmentação. Págs. 358 (ou 446) e 376 (ou 368).

195 DAMATTA, R. Carnavais, Malandros e Heróis. Para uma sociologia do dilema brasileiro. Op. Cit. Págs. 133 e 134. FLORENZANO, J. P. Op. Cit. A democracia corinthiana. Pág. 94. Mesmo quando em decorrência de crises, as equipes eram, são compelidas a mudar seus dirigentes; tais mudanças quase sempre representavam um reordenamento de forças dentro dos clubes, mas não verdadeiras rupturas. Como sugere o autor, a alternância no poder não implicava exatamente um corte com o passado, excluindo-se qualquer possibilidade de real renovação nos métodos administrativos.
} 
convertiam-se naquilo que Damatta chamou de agremiações familísticas ou patronais, ${ }^{196}$ eram, e ainda são profundamente hierarquizados, com núcleos pequenos, duros e fechados, convivendo com uma enorme cauda formada por simpatizantes, jogadores e ex-jogadores, como um cometa, no qual cada um tinha seu espaço ou papel a preencher, cabendo a poucos a primazia de presidir tais clubes e obter os dividendos gerados pelo espetáculo. Na história de Corinthians e Palmeiras, nenhum ex-jogador alcançou esta façanha. No São Paulo, apenas Roberto Gomes Pedrosa.

O mesmo fenômeno que ocorria com a memória do futebol na cidade e com a participação popular no processo de ressignificação do esporte começou a ocorrer dentro dos próprios clubes em decorrência das rivalidades internas ou de rivalidades com os outros times para controlarem as ligas e federações. Por meio de esquecimentos, genealogias foram construídas para legitimar o exercício de poder dos núcleos duros que se formavam nos clubes, em detrimento dos demais sócios, alguns fundadores, inclusive, simpatizantes, jogadores e ex-jogadores. Estava em curso uma disputa que só se encerrou por volta dos anos 1940, após a construção do Estádio Municipal, a fundação da Federação Paulista de Futebol e a consolidação do profissionalismo, fenômenos que definiram os espaços que cada grupo social ocuparia dentro do espetáculo, já plenamente ritualístico. ${ }^{197}$ Em 1930, em entrevista concedida ao periódico A Gazeta Esportiva, alguns dos fundadores do Corinthians acusavam essa situação.

"Assim, além de ficarmos mais ao par dos primeiros dias de vida corinthiana também constatamos que antigos superintendentes dos destinos do preto e branco não foram justos para com todos aquelles que contribuíram pelo aparecimento desse grêmio hoje possante e respeitado por seus pares. Todavia, é de se esperar que a actual direcção, isso faça com aquella elevação de vista que a caracteriza. Depois, é também notar que não há fidelidade no relato que se tem feito de sua fundação, notadamente no que se refere aos primeiros passos." 198

${ }^{196}$ DAMATTA, R. Carnavais, Malandros e Heróis. Para uma sociologia do dilema brasileiro. Op. Cit. Págs. 133 e 134. Para que se tenha uma ideia, em 2007, quando o Corinthians foi rebaixado para a 2. Divisão do Campeonato Brasileiro, o clube, que possui cerca de 15 milhões de torcedores, contava com apenas cerca de três mil sócios. TOLEDO, L.H. Lógicas no futebol. Dimensões simbólicas de um esporte nacional. Op. Cit. Pág. 41. Apresenta a estrutura administrativa das chamadas torcidas organizadas e chama a atenção para a existência de um organograma, baseado no exemplo da torcida Gaviões da Fiel, que pouco difere da estrutura dos clubes.

197 TOLEDO, L. H. Idem. Pág. 6. Subdivide, para efeitos de descrição e interpretação, os envolvidos com o espetáculo futebolístico ritualizado em três grandes blocos: profissionais, envolvidos diretamente com os clubes, como jogadores, técnicos e dirigentes; especialistas da crônica esportiva; e torcedores.

${ }^{198}$ Reconstituindo a história do Corinthians. A Gazeta Esportiva, 7 de setembro de 1930. Pág. 2. 
A construção do Estádio Municipal foi fundamental para a consolidação do futebol como drama ou ritual, em seus aspectos de reforço, inversão e compensação/neutralização, por diversos motivos.

Primeiro, porque seu gigantismo anulava a origem de bairro, classe ou segmento social que caracterizavam os simpatizantes das equipes de futebol, criando uma atmosfera de totalidade dentro de uma sociedade marcada pela formação de polos concorrentes. É preciso lembrar que esse gigantismo também abria perspectivas econômicas não imaginadas até então, graças às rendas dos jogos, que transformaram os clubes paulistanos em grandes contratadores/empregadores de jogadores, invertendo as relações da década de 1930, quando os clubes de São Paulo perderam seus principais jogadores para os times do Rio ou do exterior. Já entre 1942 e 1945, dois dos principais jogadores do Rio de Janeiro aportariam em São Paulo: Leônidas da Silva, atuando pelo São Paulo, e Domingos da Guia, atuando pelo Corinthians. ${ }^{199}$

Segundo, porque dentro da ideologia estadonovista, o estádio oferecia espaço para todos os segmentos sociais, ainda que sua arquitetura fosse plenamente hierarquizada com setores reservados às autoridades - tribuna de honra, cadeiras numeradas cobertas - destinadas às elites; cadeiras numeradas descobertas - destinadas às classes médias; arquibancadas com acentos - destinadas às baixas classes médias; e arquibancadas sem acentos - destinadas às classes subalternas, nas quais os espectadores ficavam sentados diretamente no concreto. Havia ainda um espaço na altura do gramado, em que se assistia ao jogo em pé. ${ }^{200}$

Terceiro, porque essa hierarquização, do ponto de vista de uma sociedade liberal e capitalista, servia de metáfora para o triunfo daqueles que ascendiam socialmente e podiam comprar os melhores ingressos. E nessa perspectiva, também possibilitava aos grupos que não ascendiam socialmente a percepção de que faziam parte da sociedade, hierarquizada, é verdade, mas algo impensável, até então - ou nos tempos do

199 TOLEDO, L. H. Op. Cit. Pág. 180. O autor apresenta uma contenda entre periodistas de Rio e São Paulo acerca do trânsito de jogadores entre as duas cidades.

${ }^{200} \mathrm{Na}$ estreia de Leônidas da Silva, em 1942, o estádio recebeu mais de 72 mil espectadores, época em que a população da cidade girava em torno de 1 milhão; porcentagem considerável da população estava presente nos estádios. 
Velódromo, quando apenas assistiam às partidas em pé, nas arquibancadas gerais. ${ }^{201}$ Daí, a possibilidade de inversão social vivenciada por esses grupos dentro dos estádios e a coexistência dialética do futebol amador, em especial o praticado nos bairros e várzeas, com o futebol profissional. Um se alimentava do outro, pois os melhores jogadores eram justamente aqueles oriundos das classes subalternas, brancos ou negros, imigrantes e seus descendentes ou nacionais caboclos, caipiras, mestiços de todo tipo que vislumbravam no futebol profissional a chance de obter ascensão social, prestígio e algum dinheiro. No campo, quando disputavam partidas com jovens oriundos das elites, podiam ser melhores e aceitos, como jamais seriam do lado de fora dos gramados.

Mesmo aqueles que não vislumbravam a ascensão por meio da prática profissional do futebol obtinham o prêmio da vitória de uma partida como o direito de hierarquizar as posições dos iguais invertendo as relações entre superiores e inferiores, como brincar com o patrão ou tirar sarro de sua cara no dia seguinte por conta do resultado de uma partida de futebol.

Perguntamos porque o futebol adquiriu essa importância como mediador cultural ritualizado em nossa sociedade. Talvez pelo fato de se tratar de uma prática cultural em que as simbologias, habilidades e referenciais corporais eram dominados por todos os segmentos da sociedade, em um contexto em que a sociedade brasileira apresentava grande heterogeneidade em seus aspectos culturais. ${ }^{202}$ Acerca das questões corporais,

${ }^{201}$ REIS, L.V.S. Na batucada da vida. Samba e política no Rio de Janeiro (1889-1930). Op. Cit. Segunda Parte. Pág. 14. Ao analisar o contexto das Escolas de Samba no Rio de Janeiro, a autora chama a atenção para a falta de sensibilidade das elites da República Velha em relação a determinadas demandas sociais e à esperteza política de Getúlio Vargas.

${ }^{202}$ VIANNA, H. O mistério do samba. Op. Cit. Pág. 48. O autor apresenta um panorama contraditório vivenciado pelas elites brasileiras no que tange a música brasileira, capazes de proferir discursos nacionalistas e ufanistas em favor de ritmos e músicos brasileiros ou discursos preconceituosos e racistas contra os mesmos. O convívio entre estrangeiros (imigrantes ou viajantes) e brasileiros também foi fundamental para que as elites cariocas repensassem a produção musical das populações negras do Rio de Janeiro. VIANNA, H. Op. Cit. Pág. 25. Bessa apresenta um breve relato acerca de Fernando Lobo, estudante da Escola Politécnica que se dedicava à produção de maxixes no uso do pseudônimo Marcelo Tupinambá. Ver. BESSA, V. Um bocadinho de cada coisa. Trajetória e obra de Pixinguinha. História e música popular no Brasil dos anos 20 e 30. Dissertação de mestrado em História Social apresentada ao Dep. de História da FFLCH - USP, 2006. Pág. 129. Algo semelhante ocorreu nos espaços futebolísticos da cidade de São Paulo, onde imigrantes e seus descendentes e brasileiros tradicionais compartilhavam práticas culturais e criavam novos referenciais. Quanto às contradições de discurso excludente e racista é preciso salientar que o mesmo Paulistano que mantinha um exclusivismo social ferrenho abrigava em suas hostes o mulato Friedenreich. 
por exemplo, há o depoimento de Santanna, que relata o episódio de uma briga dentro do Velódromo Paulista protagonizada por jovens da elite paulistana. O autor, além de mostrar que os jogadores dos clubes elitistas também eram violentos quando se viam em situações desvantajosas em partidas de futebol, dá a pista de que os jovens burgueses também dominavam as práticas corporais oriundas da capoeira, como a rasteira e a cocada (cabeçada).

$\mathrm{Na}$ obra citada em que apresenta notas biográficas de alguns jogadores de São Paulo, em 1918, o verbete sobre Mário Vespasiano de Macedo traz o relato de uma partida disputada no Velódromo por sócios do C.A. Paulistano: "em que seus players eram peritos em rasteiras e cocadas." 203 E que "houve de tudo: cabeças partidas, narizes esborrachados e pernas esfoladas" ${ }^{204}$. Por esse testemunho, podemos afirmar que aquela linguagem corporal herdada da capoeira e de outras práticas do século XIX, que foi definida por Rolnik como um saber transmitido pela dança e que recompunha uma memória mítica, ${ }^{205}$ também era compartilhada pelos indivíduos oriundos das elites, a despeito dos esforços de branqueamento desses grupos. E sugerimos que a prática da capoeira por elementos das elites cariocas do início do século XX descrita por Letícia Reis, ${ }^{206}$ parece ter se reproduzido como esporte em São Paulo pelos membros da elite paulistana, mesmo no contexto de higienização. ${ }^{207}$

Podemos pensar, pelas sugestões de Damatta, ${ }^{208}$ que não existia um único eixo hierárquico marcado pela lógica capitalista de produção ou de uma sociedade liberal na

203 SANTANNA, Leopoldo. O Football em São Paulo. Notas Critico-Biographicas dos Principaes Jogadores Paulistas, Antigos e Modernos. Op. Cit. Pág. 64.

${ }^{204}$ SANTANNA, Leopoldo. Idem, Ibidem. Pág. 64.

${ }^{205}$ ROLNIK, R. A cidade e as leis. Legislação, política urbana e territórios na cidade de São Paulo. Op. Cit. Pág. 68.

${ }^{206}$ REIS, Letícia Vidor de Sousa. Negros e brancos no jogo da capoeira. A reinvenção da tradição. Dissertação de mestrado em Ciência Social apresentada à FFLCH - USP, 1993. Pág. 6. A autora narra a prisão de Juca Reis, filho do conde de Matosinhos, figura notória da colônia portuguesa no Rio de Janeiro, em 1890, que quase gerou uma crise diplomática entre Brasil e Portugal. Existem outros relatos famosos daquela época, como o relato sobre o filho do embaixador brasileiro em Londres

${ }^{207}$ REIS, L. Idem, Ibidem. Pág. 8.

${ }^{208}$ DAMATTA, R. Op. Cit. Pág. 167. O autor sugere, na página 230, que existe a separação entre corpo e alma em nossa sociedade, com o predomínio da alma em detrimento do corpo, na hierarquia social brasileira. Quanto à esta hierarquia, penso que nem todos os grupos sociais concordam com ela, como visto no primeiro capítulo. Na página 232, ele reconhece a existência de um código cultural duplo marcado pela convivência entre uma tradição personalista e as inovações individualistas da sociedade liberal. REIS, L.V.S. Op. Cit. Segunda parte. Pág. 22, onde é apresentado o relato racista de um 
classificação das prioridades dos grupos sociais em São Paulo, algo que nos permite inferir que alguns grupos privilegiavam certos domínios, como as práticas corporais, ao lado, ou mesmo em detrimento, de outros relativos à produtividade capitalista. No que tange às elites, parece que conheciam plenamente o significado que as práticas corporais tinham em nossa sociedade e, com certeza, compatibilizavam suas prioridades capitalistas com essas práticas. Não por acaso, tiveram tino e capacidade de transformar o futebol em um grande negócio.

O encontro de estratégias simbólicas diferentes permitiu a elaboração de manejos distintos das regras ou mesmo do jogo. ${ }^{209}$ A esquiva dentro de um campo de futebol serve de metáfora para a esquiva social, mas não porque os jogadores da elite eram gentlemen, mas porque também dominavam as técnicas corporais e seus significados. $^{210}$

Alguns cronistas chegaram a omitir a violência praticada por jovens burgueses nos gramados ou tentaram relacioná-la à presença de populares nos campos. ${ }^{211} \mathrm{E}$ sobre a violência e a hostilidade decorrentes da competição e o acirramento dos ânimos entre os adeptos do esporte, os relatos sobre os distúrbios no Velódromo eram recorrentes, como salienta Gonçalves ao reproduzir uma matéria publicada pelo jornal $O$ Estado de $S$. Paulo, em 24/08/1914. A linguagem rebuscada tenta diminuir o impacto do acontecimento em um espaço frequentado por segmentos da elite, porém deixa transparecer que o problema existia desde os primórdios do futebol, inclusive entre membros da elite:

"Reprovamos sempre o procedimento dos torcedores extremados, que se julgam no direito de dirigir a um juiz os mais descabidos gestos, esquecendo, às vezes, os comezinhos princípios de boa educação e posição social dos foot-ballers da Associação Paulista e dos frequentadores do Velódromo, pertencentes todos à melhor sociedade paulista."212

intelectual do início do século XX que demonstra o quanto as práticas culturais africanas eram incorporadas pela população branca brasileira.

${ }^{209}$ TOLEDO, L.H. Lógicas do futebol Dimensões simbólicas de um Esporte nacional. Op. Cit. Pág. 64.

${ }^{210}$ TOLEDO. L.H. Idem. Pág. 65.

211 TOLEDO, L. H. Idem. Pág. 247.

212 GONÇALVES, René Duarte Jr. Fridenreich e a reinvenção de São Paulo. Op. Cit. Pág. 23. Em partida disputada entre Scottish Wanderers e Mackenzie College, em 7 de junho de 1914, houve confusão entre os jogadores, o que obrigou a direção do Scottish Wanderers a pedir desculpas publicamente por meio do periódico Correio Paulistano nos dias seguintes. Chrônica Sportiva, Correio Paulistano, 8 de junho de 1914. Pág. 3. 
Por essas características, o futebol adquiru um novo significado em nossa sociedade e seu controle passavou a ser disputado por diversos segmentos sociais. Estavam em o jogo prestígio social e a possibilidade de aferir muito dinheiro. Daí a importância dada pelo periódico, em 1919, ao lançamento de obras com visões nossas sobre o futebol. O livro "O Football em São Paulo. Notas Critico-Biographicas dos Principaes Jogadores Paulistas, Antigos e Modernos", ${ }^{213}$ publicado pelo jornalista Leopoldo Santanna, apresentava um breve relato da carreira daqueles que, na opinião do autor, eram os principais jogadores paulistas antigos e modernos. Curiosamente, Charles Miller sequer foi citado.

Dentre aqueles jogadores que atuaram em São Paulo e que disputariam o Campeonato Sul-americano de Futebol em 1919 pela Seleção Brasileira, encontramos algumas indicações interessantes, de Antonio Pigagli, Bianco Spartaco Gambini, Heitor Marcelino Domingues - do Palestra Itália; Amílcar Barbuy, Manuel Nunes - do Corinthians Paulista; Arthur Friedenreich, Sérgio Pereira - do Paulistano; Formiga - do Ypiranga; Adolfo Millon Júnior, Haroldo Domingues e Arnaldo Patusca Silveira - do Santos. $^{214}$

O verbete sobre Friedenreich apresentava sua trajetória desde a estreia no C.A. Ypiranga, em 1909, omitindo a origem no futebol varzeano. ${ }^{215} \mathrm{O}$ autor o considera o melhor atacante do futebol brasileiro naquela ocasião, quando Fried começava a atuar pelo C.A. Paulistano, depois de alguns meses de tentativas e da participação em algumas partidas amistosas em anos anteriores. ${ }^{216}$

No verbete dedicado a Amílcar Barbuy, grafado Balbuy (sic), sua origem varzeana é mencionada: "Iniciou-se no football numa equipe de arrabalde de São Paulo, o Bello Horizonte, passando logo para o Botafogo da Paulicéia, onde se conservou por três annos, salientando-se desde logo como ágil forward."

\footnotetext{
213 SANTANNA, Leopoldo. O Football em São Paulo. Op. Cit.

${ }^{214}$ Haroldo, Millon e Arnaldo atuavam pelo time do Santos Futebol Clube, time que, embora fosse da cidade portuária de São Paulo, já disputava os Campeonatos Paulistas.

${ }^{215}$ SANTANNA, Leopoldo. Idem. Pág. 41.

${ }^{216}$ GONÇALVES Jr, René Duarte. Friedenreich e a reinvenção de São Paulo. Op. Cit. Pág. 59. "No final do ano (1917), o campeão Paulistano, depois de muito tentar, contava com um novo reforço, Friedenreich, que se desligara do Ypiranga após uma suspensão da APEA, por não ter comparecido a uma partida contra a seleção carioca."
} 
Manuel Nunes é descrito como jogador talentoso, porém violento e sua origem no futebol varzeano também foi omitida. Neco, seu apelido, iniciou sua carreira no Botafogo e angariou fama na várzea pelo temperamento explosivo e pela valentia com que jogava, disputando bolas e partidas até o fim. Em diversas ocasiões, inclusive quando atuava pelo Corinthians, foi para a Delegacia após os jogos em decorrência de confusões nos campos. $^{217}$

O início varzeano de Bianco Spartaco Gambini no Tiradentes é apresentado da seguinte maneira: "Aos 12 annos iniciou, com proveito, a pratica do football, no posto de back, no Tiradentes (capital)." Sua trajetória posterior, com sua mudança para a Argentina, onde defendeu o Portenho Argentino, e sua volta para São Paulo, onde atuou pelo Corinthians, Mackenzie e Palestra Itália, foi relatada. ${ }^{218}$

A origem varzeana de Antonio Picagli também é exposta: "De 1906 data o seu noviciado sportivo, tendo-se estreado na equipe do Pernambuco F.C., desta capital, onde se conservou até 1909. Neste anno já actuava na primeira equipe. Em 1910 passou para a A.A. Lapa. Deixou esta agremiação no anno seguinte, para fundar o Ruggerone F.C." 219

Os demais jogadores paulistas da seleção de 1919 não tiveram origem varzeana. $^{220}$

O que chama a nossa atenção é que entre os principais jogadores de São Paulo selecionados por Leopoldo Santanna estão os nomes de Francisco do Nascimento Pinto e Mário Vespasiano de Macedo. Segundo o autor, Chiquito, assim era conhecido Francisco do Nascimento Pinto entre os amigos, "não se tendo revelado grande player, tornou-se um diretor excellente". ${ }^{221}$ E Mário Vespasiano de Macedo "fez parte do team Racha, do Paulistano, que tinha a obrigação de ganhar sempre... quer fosse pelo jogo, quer fosse pelo... muque”. Após se formar em engenharia, abandonou o futebol sem nunca ter jogado uma partida pelo futebol oficial ou no primeiro quadro do C.A.

\footnotetext{
${ }^{217}$ CITADINI, Antonio Roque. Neco. O primeiro ídolo. Pág. 32

${ }^{218}$ SANTANNA, Leopoldo. O football em São Paulo. Op. Cit. Pág. 20.

${ }^{219}$ SANTANNA, Leopoldo. Idem. Pág.81.

${ }^{220}$ Heitor Marcelino Domingues começou no S. C. Americano, Sérgio Pereira começou no C.A. Paulistano, Formiga começou no C.A. Paulistano, Adolfo Millon Jr. começou no Paulistano, Haroldo Domingues começou no América do Rio e Arnaldo Patusca Silveira começou no S. C. Americano.

${ }^{221}$ SANTANNA, Leopoldo. Idem. Pág. 70.
} 
Paulistano, pois tinha horror (sic) às manifestações populares (sic) e teve o mérito de ser o criador da Orchestra do Glorioso ${ }^{222}$ (sic).

Charles Miller não recebeu qualquer menção, assim como os pioneiros dos tempos da Chácara Dulley, mas esses dois nomes influentes dentro dos clubes de elite receberam verbetes dedicados às respectivas trajetórias, que se mesclavam com o futebol, não pelo fato de terem jogado futebol nos times/clubes em que militavam ou serem bons jogadores, mas por serem figuras ilustres dentro dos clubes, um como dirigente e outro como maestro.

Outro dado marcante da obra é a presença de poucos jogadores estrangeiros nos times de futebol de São Paulo. Ao todo, foram mencionados apenas catorze estrangeiros atuando nos times da cidade que disputavam o campeonato principal: Casimiro Gonzalez - espanhol e jogador do Corinthians Paulista; Carlos Teixeira Chaves português e jogador do Minas Gerais; Domingos Delascio, Luiz Olivieri e Oscar Frederici - italianos e jogadores do Palestra Itália; Eduardo Ramos - francês e jogador do Paulistano; Ramon Carmelo Fernandez e José Odolfo Fernandez - uruguaios e jogadores do Minas Gerais; Horácio Coelho - português e jogador do São Bento; Ítalo Bonsetti - italiano e jogador da A.A. das Palmeiras; Francisco Layara Filho - francês e jogador da A.A. das Palmeiras; Archibal Fouton Mac-Lean - britânico e jogador do São Bento; Sebastião Gravalos - espanhol e jogador do Minas Gerais; Ferdinando Tedeschi - italiano e jogador do Paulistano. ${ }^{223}$

No Palestra Itália, time da colônia italiana, havia apenas três jogadores italianos. Segundo o livro, o Minas Gerais seria o time que atuava com o maior número de jogadores imigrantes: quatro ao todo, sendo dois uruguaios, um espanhol e um português. Causa estranheza a citação do pequeno número de imigrantes, pois, segundo A Gazeta Esportiva, desde a década de 1910, a influência da língua italiana era sentida inclusive nas gírias utilizadas pelos jogadores de origem varzeana. Encontrava-se dificuldade no uso das preposições e verbos da língua portuguesa, em especial os atletas oriundos de bairros como o Bom Retiro, Brás e Lapa. ${ }^{224}$

\footnotetext{
${ }^{222}$ SANTANNA, Leopoldo. Idem. Págs. 64 e 65.

${ }^{223}$ SANTANNA, Leopoldo. O football em São Paulo. Op. Cit. Págs. 81 e 82.

${ }^{224}$ Letras varzeanas. Considerações a proposito de um inquerito critico sobre a influencia do italianismo. A Gazeta Esportiva, 09/02/1930.
} 
Em sua obra, Santanna relata a trajetória de jogadores que estavam diretamente relacionados ao futebol oficial, em um momento em que alguns clubes de origem popular começavam a disputar os campeonatos oficiais, da LPF ou da APEA. No geral, as informações privilegiaram os que atuavam pelo C.A. Paulistano ou outros clubes mais antigos da APEA e que tinham origem elitista. Alguns poucos jogadores oriundos da várzea foram apresentados e algumas vezes acusados de violentos. ${ }^{225}$

Sua obra nos deu pistas importantes sobre os procedimentos adotados pelos memorialistas desses grupos que consolidaram a visão idílica acerca do futebol elitista das ligas do início do século XX.

A presença da comunidade italiana nos campos de futebol em São Paulo era marcante naquele período, como atesta um artigo em A Gazeta Esportiva sobre a afluência do idioma italiano entre os times de origem varzeana. ${ }^{226}$ Outro relato importante é o deixado por um dirigente italiano por ocasião da visita do Torino, em 1914. Segundo o treinador e diretor da equipe italiana que visitou a cidade de São Paulo em 1914 e jogou contra o Corinthians,

"Uma squadra formidabile in tutte lê linee é il Corinthians, il campione Paulista, che giuoca com uma foga tremenda. Il Corinthians há nelle proprie file italiani o figli di italiani e tutti sone individualmente di classe superiore all media dei giuocatori che giuocano in Itália.",227

Santanna também não fala da presença de equipes e atletas negros, embora o espaço utilizado para a prática do futebol popular, a várzea do Carmo, fosse um espaço tradicionalmente ocupado por negros, como indica Rolnik. ${ }^{228}$

Atletas como Antenor (arqueiro), David, Dica, Deodato, Alibabá, Ernesto Bueno, Salimbano, Ladislau, Bingo, Pinheiro, Affonsinho, Bugre, os irmãos Aguiar, Zé Campeão, Zezinho, Leite, Paulino, Euclydes, Felippe, Africano, Tatu (zagueiro),

\footnotetext{
${ }^{225}$ SANTANNA, Leopoldo. O football em São Paulo. Op. Cit. Págs. 62, 64 e 68. Além de Manuel Nunes, o jogador palestrino João del Ministro era acusado de violento. Quando a violência despontava entre os jogadores dos clubes de elite, o ato era tratado com certa galhardia e com ironia, como exposto no exemplo de Mário Vespasiano de Macedo.

${ }^{226}$ Idem nota 223.

${ }^{227}$ FIGUEIREDO, Antonio. História do futebol em São Paulo. Op. Cit. Pág. 89. O autor reproduz trecho do jornal italiano Sport del Popolo de 12/10/1914.

${ }^{228}$ ROLNIK, Raquel. A cidade e a lei. Legislação, política urbana e territórios na cidade de São Paulo. Op. Cit. Págs. 62 e 63.
} 
Congo, Francisquinho, Arlindo, o 420, Zé Caetano, Isaías e Pedro não aparecem nos relatos de Santanna, mas já atuavam antes de 1917 e, segundo o jornal, já se destacavam pela qualidade técnica apresentada em campo. E os primeiros times formados por negros já existiam em 1909, como o Diamantino F.C., Perdizes F. C., o São Paulo F. C. e o Aliança, disputando os campeonatos de uma liga varzeana. ${ }^{229}$

A inclusão dos negros nos esportes nos EUA foi possível em decorrência de duas frentes: pressão interna dos movimentos sociais existente desde os anos 1930 e a necessidade de neutralizar a propaganda política soviética em plena Guerra Fria. ${ }^{230}$ Em São Paulo, quanto ao futebol, a inclusão ocorreu de maneira diferente pela fundação de equipes e ligas exclusivas na primeira década do século $\mathrm{XX}$, o que não significa ausência de racismo em nossa sociedade, mas, sim, que a ressignificação do futebol sofre influência desse segmento da população desde seus primórdios.

Outro aspecto importante da obra de Santanna é o que destaca as rivalidades entre dirigentes paulistanos e cariocas pelo controle da CBD e da Seleção Brasileira, e deixa transparecer o enfraquecimento do futebol de São Paulo em relação ao do Rio. O que não é comentado é que o futebol carioca apresenta, na década de 1920, organização e espaços melhores para a prática do futebol que os encontrados em São Paulo. O campo do Fluminense era, segundo Mazzoni, o primeiro estádio brasileiro, o que permitia a organização de partidas que gerassem melhores rendas aos clubes envolvidos desde 1919. Todavia, no entender do autor acima citado, o declínio técnico do futebol de São Paulo estava relacionado com a abertura da APEA para times de origem popular.

"E essa supremacia, conquistada sem grande esforço, e que temos sabido manter durante tão longo tempo - de 1901 a 1925 - não pode ser espesinhada, unicamente porque, dadas as fundas discórdias que vêm minando o esporte de nossa terra, perdemos por um único ponto no ultimo Campeonato Brasileiro. Decahimos - por que não dizer? - na sociabilidade. De há uns dois annos para cá começaram a lavrar nas altas espheras do nosso esporte as mais tristes discórdias. Formaram-se partidos políticos no seio da entidade máxima; e vieram as rixas; e nasceram desconfianças; e romperam as represálias... A atmosphera reinante suffoca." 231

\footnotetext{
${ }^{229}$ Uma visita aos quadros de cor! Os quadros actuaes e antigos constituídos exclusivamente por jogadores pretos - A curiosa fundação do E.C. Piracicabano. A Gazeta Esportiva, 22/06/1930. Pág. 8.

${ }^{230}$ CRONIN, Mike e MAYALL, David. Sporting Nationalisms. Identity, Ethnicity, Imigration and Assimilation. Londres, F. Cass, 1989. Ver o capítulo Opportunities Gained. African-Americans and the American Way of life. Págs. 193-242.

${ }^{231}$ SANTANNA, Leopoldo. Supremacia e decadência do futebol paulista. Op. Cit. Pág. 14.
} 
Quando fala em supremacia, Santanna está discutindo as relações futebolísticas dos clubes cariocas e dos paulistanos, disputa que envolvia os dirigentes esportivos das duas cidades para ver quem controlaria os rumos do futebol brasileiro, batalha esta que, desde o início, se mostrava perdida para os clubes paulistanos pelo fato de o Rio ser a capital do País e ter um futebol com maior amplitude. ${ }^{232}$ Desde o início dos anos 1920 , essa disputa obrigava os dirigentes paulistanos a adotar discursos que legitimassem suas pretensões políticas e econômicas dentro do futebol.

$\mathrm{Na}$ visão de Santanna, a decadência paulistana não estava relacionada às deficiências técnicas dos jogadores da cidade ou à falta de interesse dos torcedores, mas relacionava-se diretamente com a incapacidade dos dirigentes dos clubes e das ligas de se organizarem em condição de pleitear o controle do esporte em esfera nacional e pelo processo de profissionalização que aproximava ricos e pobres nos campos de futebol.

A sua percepção sobre o papel da memória futebolística em São Paulo está no capítulo 6 em que discute as origens do futebol denominado "Factores vários que tambem comprovam a superioridade do futebol paulista." É bem categórico ao afirmar que "e quanto à prioridade da adopção do futebol no Brasil? É mais uma primazia que cabe à terra dos Bandeirantes." 233 Seu breve relato aponta a introdução do futebol por Charles Miller, que, na obra, é tratado como britânico, o pioneirismo da Liga Paulista de Futebol em relação às demais ligas brasileiras, assim como as relações com ligas de outros países como fatores que contribuíram para que os dirigentes paulistas conquistassem o controle do futebol brasileiro.

\subsection{Profissionalização e ritualização do futebol em São Paulo.}

"O profissionalismo veiu estabelecer um triste desequilíbrio em nossos meios futebolísticos. Indivíduos de educação nulla, de moral duvidosa, que se adestraram pelas várzeas no manejo da pelota, tornaram-se desejáveis. Muitos delles, descobertos por emissários solertes, foram disputados a peso de ouro. E esses elementos, scientes de representarem um capital-dinheiro que vale mais que o capital-aptidão, sabem que dificilmente podem ser postos à margem. Dahi, as continuas indisciplinas em campo. E essas indisciplinas, sempre graves,

\footnotetext{
232 ANTUNES, F.R.F. “Com brasileiro, não há quem possa!” Op. Cit. Pág. 175. Um período um pouco posterior ao de Santanna (1925), entre 1930 e 1950.

${ }^{233}$ SANTANNA, Leopoldo. Supremacia e decadência do futebol paulista Op.Cit. Pág. 147
} 
sempre depreciadoras, quase nunca podem ser severamente punidas pela entidade superior. Porque os clubes interessados, visando a defesa do capitaldinheiro, queimam até os últimos cartuchos na defesa do seu... amador! E rebentam os casos, os famosos casos que, de tempos a tempos, têm convulsionado nossos meios esportivos." 234

“(...) dedico este livro à memória de meus companheiros de futebol que morreram na indigência depois de terem contribuído para a glorificação do soccer nacional - humildes operários que à custa de sacrifícios enormes, inclusive o da própria vida, legaram aos clubes os estádios de cimento armado que esses ostentam hoje nos diversos bairros aristocratas das principais cidades do país, com salas douradas e pistas de baile para o gozo exclusivo de diretores e dos sócios ricos; dedico ainda aos pioneiros e paladinos da cruzada humana da legalização profissional: jornalistas, jogadores, diretores e clubes; dedico-o também aos meus amigos sinceros que não me negaram nunca o conforto de sua amizade; dedico-o, finalmente, aos companheiros mutilados que arrastam hoje sua miséria física de homens inválidos para outras atividades, mendigando o pão de cada dia, esquecidos e desprezados por aqueles que exploraram seu vigor muscular e sua mocidade." 235

Devemos levar em consideração a formação de um novo campo profissional que se delineou desde a década de 1910. Existia, e ainda existe, uma diferença de concepção acerca do futebol entre aqueles que o concebiam e o concebem como drama/ritual - os torcedores, e aqueles que o concebiam como um campo de disputas por práticas e experiências profissionais, poder, visibilidade e legitimidade institucional. ${ }^{236}$ Para os que atuavam nos campos do futebol oficial/profissional, o valor simbólico de cada partida ou competição era bem diferente daquela existente entre os torcedores e as equipes, como salienta Toledo. ${ }^{237}$ A recompensa material era um fator imediato que diferenciava o profissional do torcedor/simpatizante desde 1912.

O processo de profissionalização foi marcado por um contexto de tensão e negociação entre os jogadores e os dirigentes das equipes e ligas até 1941, quando o Governo Vargas normatizou o futebol de todo o País. A popularização do futebol esteve vinculada não apenas à constituição de um campo profissional, mas também ao modo como essa modalidade esportiva foi apropriada nas várias formas de praticá-la e

\footnotetext{
${ }^{234}$ SANTANNA, Leopoldo. Idem. Pág. 156.

${ }^{235}$ CORREIA, Floriano Peixoto. Grandezas e misérias do nosso futebol. Pág. 11.

236 TOLEDO, L.H. Lógicas no futebol. Op. Cit. Págs. 31 e 69. O autor lembra que, na perspectiva daqueles que atuam como profissionais, a busca por resultados e a tentativa de eliminar o imponderável das partidas são fundamentais para o êxito da atividade.

${ }^{237}$ TOLEDO, L.H. Op. Cit. Pág. 10.
} 
vivenciá-la. $^{238}$ Não podemos falar que a profissionalização e o desenvolvimento competitivo do esporte liquidaram o encantamento que o jogo causava/causa entre aqueles que o acompanhavam.

Nesta parte do trabalho, discutimos o processo que consolidou a profissionalização no futebol de São Paulo. Durante o período estudado, as relações entre a indústria do entretenimento e a profissionalização não estavam plenamente estabelecidas ou eram problemáticas e nem sempre permeadas pelas relações capitalistas de produção, algo que, no futebol, só se consolidou entre 1933 e 1941. Mesmo após a consolidação do profissionalismo, tal prática sempre se mostrou cheia de fissuras e desigualdades, tanto na realização enquanto competição de alto nível, quando na preparação dos atletas para tal fim, ou em termos de visibilidade e possibilidade de ascensão social para os profissionais envolvidos. ${ }^{239}$

Ao discutir o constante troca-troca de jogadores pelos clubes paulistanos que atuavam pela Liga Paulista de Futebol, nos primeiros anos de sua existência, Plínio Negreiros afirmou que esses eram constantes e que não é seguro afirmar que ocorressem apenas por motivos financeiros, existindo o aspecto do prestígio social de cada clube. ${ }^{240}$

É lícito pensar, pelo que sugere o autor, que aqueles jovens oriundos da elite não demandavam salários e jogaram pelo prestígio que a atividade gerava para os jogadores de determinadas equipes. Entretanto, os clubes que disputaram as partidas das principais ligas da cidade - LPF ou APEA, desde o início da década de 1910, buscavam se reforçar com atletas oriundos de outras equipes dentro daquilo que os periódicos definiam como cavação, isto é, o ato de cavar/buscar jogadores em outras equipes. $\mathrm{O}$ Club Athlético Paulistano isentava todos os jogadores que atuavam nos dois times principais de futebol de qualquer mensalidade com o clube desde 1916, pelo menos. Claro que o preço pago por esses atletas era pelo fato de participarem da associação como sócios com menos direitos que os demais, ou seja, não tinham direito de voto nas assembléias. $^{241}$

\footnotetext{
${ }^{238}$ TOLEDO, L.H. Op. Cit. Pág. 24.

239 TOLEDO, L.H. Lógicas no futebol. Op. Cit. Págs. 87 e 124. O autor chama a atenção para a manutenção de práticas de aliciamento e recompensa dentro dos clubes ainda hoje, que são muito parecidas com aquelas do começo do século.

${ }^{240}$ NEGREIROS, Plínio José Labriola de Campos. Resistência e rendição. Op. Cit. Pág. 73.

241 Arquivo do Estado. Estatutos do Club Athlético Paulistano, de 17/11/1916. C 10417. 470 - A. Segundo o Artigo 4. ${ }^{\circ}$, Parágrafo Único. “Os sócios que fizerem parte do primeiro e do segundo team de
} 
Em 1933, o lançamento do livro Grandezas e misérias do nosso futebol, com depoimentos do jogador Floriano Peixoto Correia, causou grande polêmica nos meios esportivos brasileiros. Pelo seu relato, as condições precárias que assolavam as carreiras esportivas de muitos jogadores, sobretudo daqueles das camadas mais populares, mas não apenas, vieram a público, estimulando grande campanha midiática em defesa da profissionalização do futebol. ${ }^{242}$

As relações entre atletas, clubes e ligas eram mediadas pelo dinheiro desde, pelo menos, 1902. Desde 1912, a prática do falso amadorismo criava confusão dentro dos campos, pelo menos desde 1917, era norma vigente entre as equipes que disputavam o Campeonato Paulista. Também não podemos nos esquecer das intenções que fundaram a Liga Paulista de Futebol e construíram o Velódromo Municipal.

O relato de Jorge Americano é importante para percebermos que a criação da Liga Paulista de Futebol ocorreu simultaneamente à difusão do esporte nas ruas da cidade de São Paulo. O autor informa que "tinha assistido por esse tempo (entre 1900 e 1902), a uma ou duas corridas de bicicletas, no Velódromo, à Rua da Consolação, onde mais tarde foi aberta a Rua Nestor Pestana. Não sabia se já se jogava futebol ali, ou não. Nas ruas, toda gente jogava." ${ }^{243}$ Para os que fundaram a LPF, o campeonato em si já era um ótimo negócio apenas com a venda de ingressos.

No período estudado, muitos periodistas discutiram se a profissionalização era um procedimento correto ou não e descreviam um passado nostálgico supostamente marcado pelo amadorismo, que nunca existiu no plano da LPF. Leopoldo Santanna afirma com certo desdém, na década de 1920, que "nos dias que correm, os amadores têm, além das despesas de viagem e estadia completamente pagas, ajuda de custo e, não raro, extras para imprevistas despesas..."244

football e os do primeiro team que tomaram parte no campeonato de 1916 não são obrigados ao pagamento de contribuição, mas não terão voto nas assembléias". Atualmente definidos como militantes, essa prática foi corriqueira durante o século XX em todos os clubes, independentemente da modalidade esportiva.

${ }^{242}$ TOLEDO, L.H. Lógicas no futebol. Op. Cit. Pág. 45. Dentre os artigos publicados naquela ocasião, citaremos o escrito por Salathiel de Campos. Os males do falso amadorismo do nosso futebol. A Gazeta Esportiva. 28/11/1932. Pág. 12.

${ }^{243}$ A MERICANO, J. São Paulo naquele tempo (1895 - 1915). Pág. 295.

${ }^{244}$ SANTANNA, Leopoldo. Op.Cit. Pág. 22. Interessante notar que esse subitem se chama "Nos áureos tempos... - O verdadeiro amadorismo". 
Os que defendiam o amadorismo não perceberam que é o processo de especialização que caracteriza qualquer forma de entretenimento urbano ${ }^{245}$ e promove a profissionalização dos envolvidos, o que também ocorria no futebol paulistano no momento. Isso porque as atividades de lazer que mobilizavam os pobres e poderiam gerar lucros exigiam atletas melhor qualificados para atender às demandas de um público cada vez mais exigente. Qualificação que só seria possível na medida em que os atletas se dedicassem exclusivamente às atividades do futebol. Se, na origem, a exploração do negócio era feita por particulares, pequenas empresas ou ficavam à margem dos grandes negócios, no decorrer do século os espaços futebolísticos vivenciaram uma verdadeira Revolução Industrial. ${ }^{246}$

Em parte do período estudado, por ser proibido pelas ligas oficiais, o profissionalismo ganhou contornos um pouco diferentes, pois os atletas não eram publicamente remunerados para praticar o futebol, mas recebiam dinheiro para jogar, de maneira escamoteada. Em alguns casos, os clubes ou dirigentes lhes arrumavam trabalhos e empregos de fachada para que se dedicassem exclusivamente ao futebol. Ou concediam a exploração de um espaço dentro do clube, como no caso de Amílcar Barbuy, que controlava a venda de bebidas no campo do Corinthians na Chácara da Floresta, entre 1917 e 1923.

Daí, o termo falso amadorismo ou semi profissionalismo. As situações suspeitas dessas práticas eram denunciadas nos periódicos da época, como nota Negreiros. ${ }^{247} \mathrm{O}$ depoimento de Corrêa acerca dos procedimentos do próprio Paulistano e outras equipes em relação ao profissionalismo ou semi profissionalismo é interessante:

"O profissionalismo é coisa moderna, afirmam os falsos amadoristas. Entretanto, em 1910, o zagueiro Asbury vencia $100 \$ 000$ por jogo no C.A. Paulistano; em 1911, os irmãos Bertoni tinham ordenado fixo no S.C. Americano; o Center-half Aquino, tendo ido certa vez receber seu dinheiro n'A Tribuna, em Santos, foi surpreendido com um envelope que trazia o timbre da casa de despachos de Ernesto Guimarães; Benedito Santos (Zé Macaco) foi importado pelo Botafogo para o Rio; em 1916, a ala esquerda Mac-Lean-Hoppckins fez contrato com o

\footnotetext{
${ }^{245}$ HOBSBAWN, E. J. História Social do Jazz. Rio de Janeiro, Paz e Terra, 1991. Pág. 176.

${ }^{246}$ HOBSBAWN, E. J. Op. Cit. Págs. 178 e 179. O autor se refere a todas as formas de entretenimento no ocidente, não apenas especificamente ao futebol.

${ }^{247}$ NEGREIROS, Plínio José Labriola de Campos. Op. Cit. Pág. 74.
} 
S.C. Americano, contrato lavrado em tabelião, para vencer $500 \$ 000$ por mês, jogando pelo clube verde e branco." 248

Um dos casos mais complicados de falso amadorismo envolveu jogadores do Paulistano e do Corinthians, entre outubro de 1918 e março de 1919. Por ocasião dos preparativos da Seleção Brasileira para o Campeonato Sul-americano que ocorreria no Rio de Janeiro, em novembro daquele ano, Friedenreich, do Paulistano, Amílcar e Neco, do Corinthians, receberam dinheiro da APEA para se sustentarem no Rio de Janeiro, durante o período em que lá ficassem se preparando para o torneio. ${ }^{249} \mathrm{Em}$ decorrência do surto da Gripe Espanhola, os jogadores não puderam embarcar para o Rio de Janeiro, perderam seus bilhetes, utilizaram o dinheiro para cobrir despesas pessoais e não tiveram como ressarcir a APEA.

Além de suspendê-los, a Confederação Brasileira de Desportos expulsou a entidade paulista em janeiro de 1919, quando esta se recusou a aplicar a pena contra os atletas. $^{250}$ Durante o primeiro semestre inteiro de 1919, os periódicos cariocas e paulistas denunciaram e acusaram os atletas e clubes dos outros Estados pela prática do profissionalismo disfarçado de falso amadorismo, ${ }^{251}$ indicando que tais práticas não eram desconhecidas ou incomuns.

O termo falso amadorismo identificava o ato de remunerar os jogadores de futebol para que eles atuassem pelas equipes e desempenhassem suas funções da maneira mais eficiente possível, de forma a permitir que as equipes conquistassem os títulos e resultados desejados, em uma época em que as elites brasileiras afirmavam que os esportes deveriam ser instrumentos de higienização social e remodelação moral daqueles que o praticavam, razão pela qual toda e qualquer remuneração aos atletas era mal vista ou mesmo proibida pelas entidades que organizavam os esportes. Mas, na

\footnotetext{
${ }^{248}$ CORREIA, F. Op. Cit. Pág. 222.

${ }^{249}$ Uma notícia importante. Amílcar, Neco e Fried suspensos pela CBD. O Estado de S. Paulo. 16/12/1918. Pág. 5. Um caso melindroso. Receberam ordenado da APEA. O Estado de S. Paulo. 17/12/1918. Pág. 6.

${ }^{250}$ GONÇALVES, René Duarte Jr. Fridenreich e a reinvenção de São Paulo. Op. Cit. Pág. 59. Segundo o autor, a querela só foi resolvida porque a Seleção Brasileira precisa destes jogadores para ter condições de ganhar o torneio que foi disputado no Brasil em 1919. Interessante notar que Mazzoni, embora discuta o perdão dos jogadores, nada fala dos motivos da suspensão.

${ }^{251} \mathrm{O}$ catonismo da Confederação. Multiplicam-se os casos de profissionalismo. O Estado de S. Paulo. 28/02/1919. Pág. 6. O profissionalismo no football. A lei do estágio. O Estado de S. Paulo. 15/03/1919. Pág. 6.
} 
prática, todos os jogadores eram profissionais dentro de um regime que contraditoriamente proibia o profissionalismo e, conseqüentemente, estimulava a precariedade nas relações trabalhistas entre clubes e jogadores.

A especialização das atividades dentro dos clubes, a partir desse contexto histórico, onde cada um exerce uma atividade em um sistema parecido com o organograma de uma empresa, transformou os jogadores em proletários da bola, pois, na prática, não tinham direitos ou qualquer proteção previdenciária por parte dos clubes ou do Estado e eram mal remunerados. A ampliação da participação de jogadores pobres e a direção exercida por membros das classes mais altas criavam situações que fomentaram a precariedade das atividades profissionais dos primeiros, a lucratividade em excesso dos últimos e a construção dos patrimônios dos clubes para o usufruto dos sócios. ${ }^{252}$

Ao discutir o tema profissionalização no campo musical no mesmo período, Virgínia Bessa sugere que a questão desse profissionalismo incipiente se relacionava com o passado paternalista herdado dos tempos da escravidão. ${ }^{253}$ As fontes indicam que, além da herança do paternalismo escravocrata, ao menos nos espaços futebolísticos, essas relações eram marcadas pela precariedade vivenciada pelos trabalhadores, não apenas músicos ou jogadores de futebol, e pela exploração extrema dos clubes. Por isso, a bandeira da profissionalização foi levantada por diversos jogadores daquela época, como o próprio Friedenreich, ${ }^{254}$ enquanto os clubes oscilavam em suas posições sobre o tema.

252 É importante notar que os atletas eram sócios dos clubes, mas quando se aposentavam ou se transferiam para outros clubes, perdiam o direito de usufruírem os espaços exclusivos dos sócios. Durante todo o século XX, diversos ex-craques passaram por situações constrangedoras nas portas dos clubes.

253 BESSA, V. Um bocadinho de cada coisa. Op. Cit. Pág. 127. No campo musical, ela percebe uma diferença entre brancos - alguns se recusavam a receber por apresentação, caso do Bando dos Tangarás, conjunto de onde despontaram Noel Rosa, Almirante e João de Barros e negros - que quase sempre recebiam para tocar no que tange à profissionalização, ao ganhar dinheiro com a música. Sua interpretação, baseada em bibliografia, aponta para a estigmatização da atividade de entertainer em uma sociedade de herança escravista.

${ }^{254}$ SEABRA, O.C.L. Op. Cit. Pág. 357 (ou 445). A autora apresenta carta de Friedenreich endereçada a Max Valentim por ocasião da publicação do livro O futebol e sua técnica, de autoria de VALENTIM, Max. Nessa carta, Fried recorda a batalha pelo profissionalismo do esporte, da qual ele foi um dos soldados. Essa carta deixa transparecer que diversos jogadores brancos atuaram pela profissionalização, deixando entrever que a questão da profissionalização no futebol não se restringia ao problema étnicoracial, mas dizia respeito, também, à origem social dos que se envolviam com as atividades de entretenimento. 
Desde 1928, pelo decreto federal de $\mathrm{n}^{\circ}$ 5.492, os contratos entre jogadores e clubes eram equivalentes aos praticados entre músicos e demais profissionais com casas de diversões e deveriam apresentar, em suas cláusulas, o local em que o(s) jogador(es) deveria(m) cumprir suas obrigações, o tempo de serviço a ser cumprido, a natureza da atividade, remuneração e formas de pagamento. ${ }^{255}$ Eric Hobsbawn, ao analisar a formação do campo musical profissional em torno do Jazz nos EUA, chama a atenção para os aspectos em comum entre esses ambientes sociais, que levavam os jovens pobres para o mundo do entretenimento, do qual o futebol faz parte. ${ }^{256}$

A busca pela profissionalização que marcava/marca muitos brasileiros jovens dentro desse novo segmento econômico gerado pelo futebol se explicava, também, por ser o futebol um dos poucos espaços na sociedade brasileira em que aqueles que pertenciam aos extratos mais baixos poderiam almejar uma pequena possibilidade de ascensão social pelo seu talento com a bola, já que não tinham acesso aos processos tradicionais que marcam a ascensão social nas sociedades capitalistas ocidentais desde o calvinismo. ${ }^{257}$ Mesmo os jogadores medianos, poderiam ter a oportunidade de conseguir empregos melhores nas fábricas ou escapar dos processos de proletarização e exploração extrema do sistema capitalista caso possuíssem talento com o futebol. ${ }^{258}$

Não significa dizer que os jovens da elite desapareceram dos campos, mas que as relações sociais estabelecidas os distanciavam das práticas futebolísticas profissionais que se forjavam naqueles tempos, na medida em que podiam almejar trabalhos melhores. Em meados de 1941, os jovens da elite já eram minoria nos quadros dos times de futebol do campeonato oficial, mas ainda podemos encontrá-los jogando nos

\footnotetext{
255 Contratos de jogadores. A Gazeta Esportiva. 28/08/1939. Pág. 7.

${ }^{256}$ HOBSBAWN, E. J. Op. Cit. Págs. 217 e 218. "O artista surge dos trabalhadores não qualificados, $e$ tocar (no nosso caso, jogar futebol), para os pobres tem uma posição social peculiar. No mundo do qual ele vem e onde ele trabalha, entretenimento (que significa qualquer talento pessoal ou dom vendido para o público ver, ouvir ou usufruir de outra forma, do corpo para a alma) não é apenas uma forma de ganhar a vida, mas muito mais importante, uma maneira de se criar um caminho próprio dentro do mundo, só comparável ao crime e a política, com a religião, do tipo vivido pelos próprios pobres para si mesmos, vindo pouco atrás. É essencial lembrar disto. O músico, o dançarino, o cantor, o comediante, o boxeur ou o toureiro que alcançam o estrelato, não fazem sucesso apenas no meio do público do esporte ou da arte em questão, mas são potenciais primeiros cidadãos de suas comunidades, ou de seu povo."

${ }^{257}$ HOBSBAWN, E. J. Op. Cit. Pág. 218. O autor lembra que a formação de uma poupança familiar, dedicação intensa ao trabalho ao longo da vida e busca incessante pela escolarização não eram opções abertas a esses jovens.

${ }^{258}$ Como testemunho pessoal, lembro que meu avô materno só conseguiu se formar como técnico de contabilidade, no bairro de Santo Amaro, nos anos 1950, após encontrar um emprego em um banco graças ao seu talento com a bola.
} 
principais times na década de 1940. Ermelino Matarazzo que foi goleiro juvenil do Palmeiras, entre 1943/1945, ${ }^{259}$ possuía amigos que atuavam no São Paulo Futebol Clube e no Juventus e, muitas vezes, se reuniam na casa da família Matarazzo, na Avenida Paulista. ${ }^{260}$

${ }^{259}$ ANTUNES, F. M. R. F. Op. Cit. Pág. 132.

${ }^{260}$ ANTUNES, F. M. R. F. Op. Cit. Pág. 134. 


\section{PARTE II}

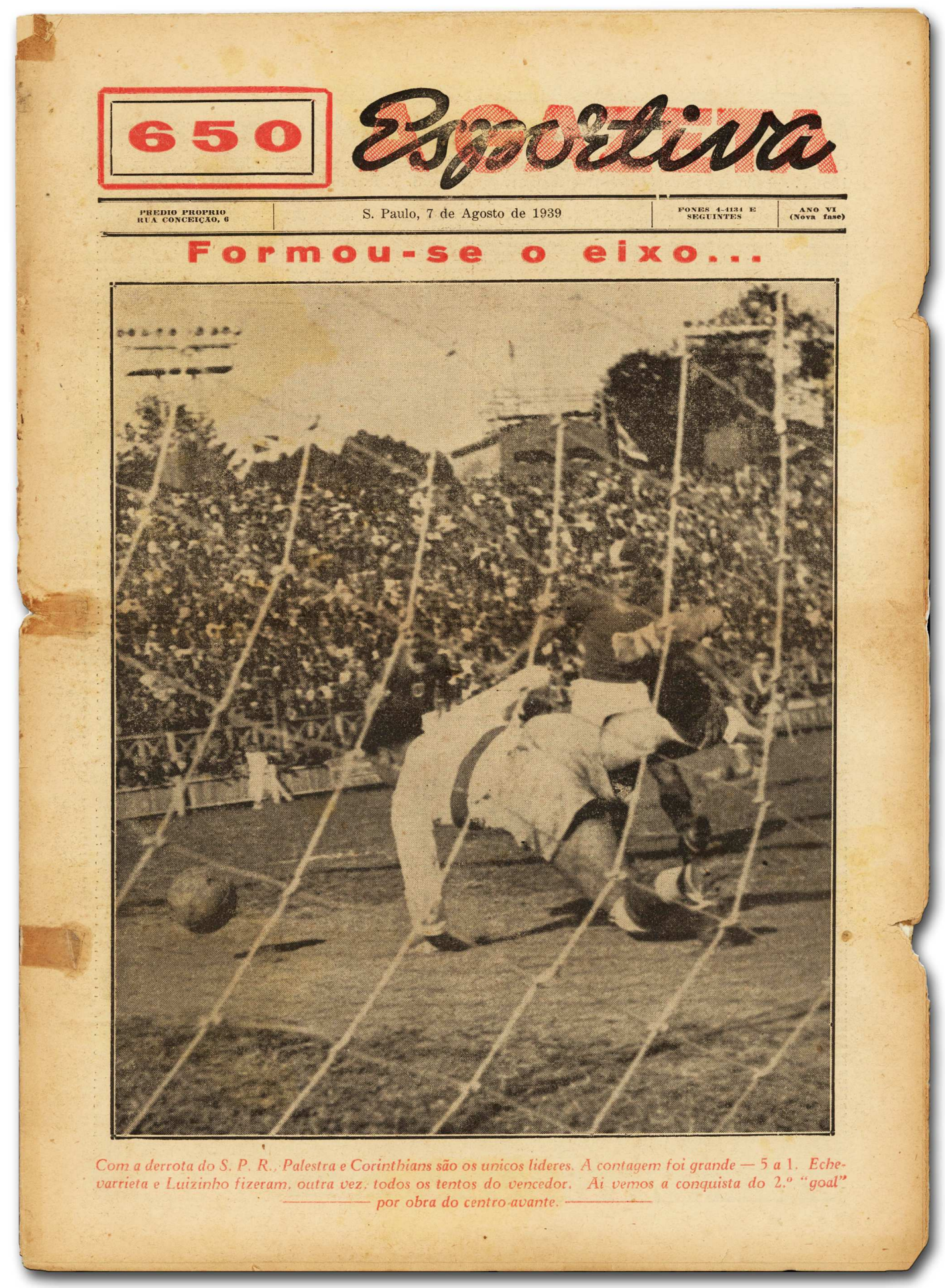

“...- do futebol paulistano". 


\title{
3 São Paulo Futebol Clube. $O$ time herdeiro do futebol elitista do início do século XX?
}

\author{
3.1 O desaparecimento dos clubes de elite dos campeonatos de futebol e o \\ imaginário tricolor.
}

\begin{abstract}
"Um retrato produzido por um sociólogo norte-americano, Donald Pierson, através de uma amostra, na tentativa de descrever o que eram considerados níveis superiores e inferiores de moradia na cidade de São Paulo nos anos 40, aponta claramente este contraste. Na amostra escolhida, de um lado estavam cem casas situadas no Bexiga, Mooca e Canindé; do outro, cem casas do Jardim América, Pacaembu e Higienópolis. A amostra escolhida não incluía casas construídas na nova periferia da cidade. Na descrição de Pierson, estão presentes as características espaciais dos territórios populares, reiteradas através do século: presença de várias famílias na mesma edificação; quintais coletivos; uso misto do prédio; porões habitados; áreas de lavar roupa e cômodos multifuncionais nas casas; familiares de diferentes sexos e idades compartilhando o mesmo cômodo." 261
\end{abstract}

"Quando fui contratado pelo S.P.F.C., muitos me diziam que estava chegando ao melhor clube brasileiro. Não precisei de muito tempo para constatar isto na prática. Estrutura invejável - tanto física como de pessoal - logo percebi que esse clube estava à frente do seu tempo e que frequentemente serviu de fonte de inspiração para seus adversários... Ao passear por essas páginas, vê-se que esse pioneirismo é histórico, basta dizer que o clube que deu origem ao São Paulo, o Clube Atlético Paulistano - fundado inicialmente para o ciclismo (talvez uma inspiração para o Leônidas e cia.) -, construiu a primeira pista de ciclismo oficial do país." 262

"Rua 11 de agosto, 9 - A. Nesse local, a 16 de dezembro de 1935, um grande número de pessoas se reunia, atendendo a um convite do Grêmio Tricolor, e fundava o novo São Paulo Futebol Clube. Um clube formado em 1930 pela fusão do C. A. Paulistano e da A.A. das Palmeiras e extinto com a anexação ao Tietê por causa da dívida de 190 contos de réis. Os primeiros tempos foram muito difíceis, sem sede, com pouco dinheiro." 263

\footnotetext{
${ }^{261}$ ROLNIK, R. Op. Cit. Pág. 185.

${ }^{262}$ GIACOMINI, C. São Paulo. Dentre os grandes, és o primeiro. São Paulo, Ediouro, 2005. Contracapa assinada pelo ex-jogador Raí.

263 PIMENTEL, Odair e PENNA, Maysa. São Paulo Futebol Clube 1935 - 1980. São Paulo, Mauro Ivan Marketing Editorial, 1981. Pág. 9.
} 


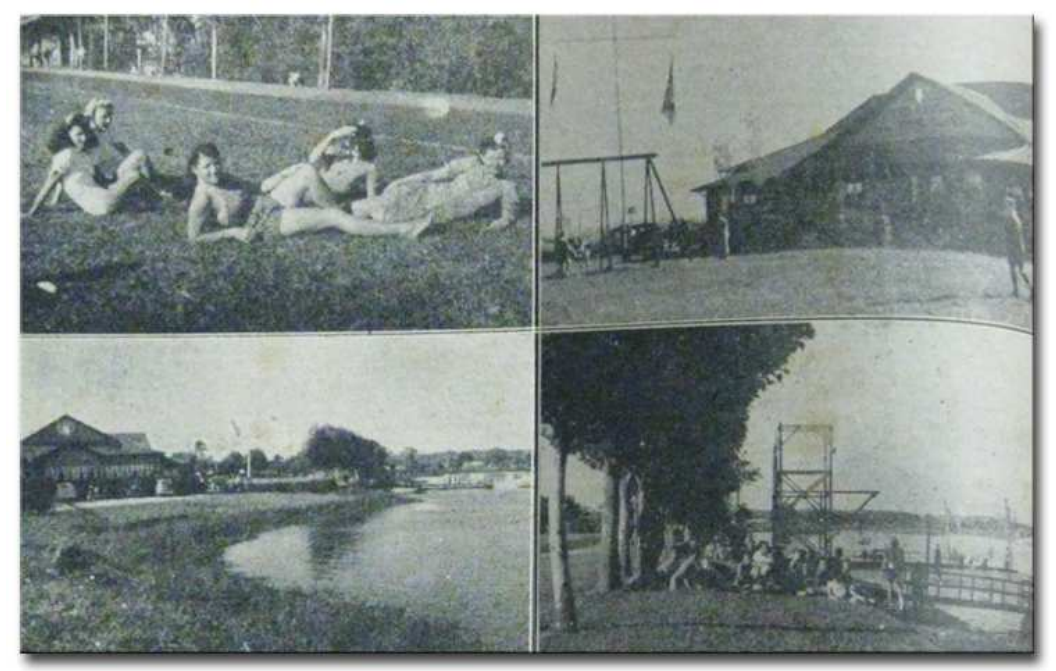

5. Sede do São Paulo Futebol Clube no bairro do Canindé, em 1942.

O tema da profissionalização das atividades no futebol era polêmica desde o início do século XX. Sua adoção era criticada por diversos setores dirigentes que, no entanto, quando foram obrigados a adotarem-na, construíram uma tradição narrativa que apagou qualquer vestígio de participação e iniciativa dos jogadores em busca de seus direitos, acentuando o papel dos dirigentes.

A leitura da obra de Mazzoni, por exemplo, nos leva a pensar que a profissionalização só foi adotada no futebol brasileiro porque, após a I Copa do Mundo, realizada em 1930, no Uruguai, os clubes europeus começaram a assediar os atletas sulamericanos. Não se mencionam as greves que os jogadores platinos organizaram naquela ocasião para obrigarem a adoção do profissionalismo ${ }^{264}$ ou as expectativas, e eventuais mobilizações, dos jogadores brasileiros de melhorar de vida pela assinatura de contratos profissionais.

Segundo ele, para impedir que os atletas partissem imediatamente para o exterior, os clubes dos países platinos adotaram a profissionalização em 1931, seguraram seus jogadores com a assinatura de contratos profissionais e passaram a cobiçar os melhores jogadores brasileiros na mesma estratégia. No futebol paulistano, Corinthians e Palestra Itália perderam, para equipes europeias, quatro jogadores titulares cada um de uma só vez: Del Debbio, Filó, Rato e De Maria, do Corinthians; Pepe, Serafim, Tedesco e Ministrinho, do Palestra Itália.

${ }^{264}$ FlorenZanO, J. A Democracia Corinthiana. Práticas de liberdade no futebol brasileiro. Op. Cit. Pág. 45. 
Para conter a fuga de talentos, alguns clubes brasileiros oficializaram, a partir de 1933, o profissionalismo, ${ }^{265}$ desfiliaram-se da CBD e fundaram a Federação Brasileira de Futebol, que apoiava a profissionalização. A medida dividiu o futebol brasileiro, em todos os Estados, entre amadores e profissionais e permitiu um aumento considerável nas rendas dos clubes do Rio de Janeiro que se profissionalizaram, pela melhoria na organização dos campeonatos. Em São Paulo, as equipes adotaram o profissionalismo imediatamente. Com a reinauguração parcial do Parque Antarctica e as novas instalações nos demais clubes, conseguiram rendas recordes no campeonato de 1933. O único problema da história ficou sendo o fato de os clubes não poderem organizar partidas amistosas contra times estrangeiros, atividade que lhes era muito importante na geração de renda, uma vez que apenas a CBD tinha autorização da FIFA para organizálas no Brasil.

Naquela década, Palestra Itália e Corinthians se consolidaram como os principais times da cidade. Seus dirigentes só aderiram plenamente ao profissionalismo em 1933 porque perceberam os benefícios que a medida traria para as equipes. O Corinthians foi o time mais afetado da cidade pelo assédio das equipes europeias; tricampeão em 1930, em 1932 seus torcedores assistram atônitos a derrotas marcantes como a de 8X0 para o Palestra Itália. E com a mesma facilidade com que aderiram ao profissionalismo e fundaram uma nova Federação, voltaram atrás em 1934, quando a CBD lhes concedeu benefícios financeiros ${ }^{266}$ e acenou com a possibilidade de organizarem partidas internacionais de futebol.

Desfiliaram-se da APEA, que havia rompido com a CBD em decorrência da profissionalização, criaram a Liga Bandeirante de Futebol, vinculada à CBD, pressionaram as equipes cariocas para que apoiassem seus desejos de monopolizar o controle da APEA e desestruturaram seus concorrentes financeiramente. Entre fevereiro

\footnotetext{
${ }^{265}$ MAZZONI, T. História do futebol no Brasil. Op. Cit. Pág. 236. Para quem os clubes cariocas já discutiam o tema em agosto de 1932, mas só chegaram a um acordo no início de 1933, quando, em parceria com a APEA, anunciaram a adoção do profissionalismo nas duas cidades, junto com a criação do Torneio Rio - São Paulo. Dos grandes times do Rio, apenas o Botafogo não concordou com a iniciativa, enquanto que em São Paulo, clubes tradicionais como o Germânia e o Internacional desistiram do futebol, por não terem estrutura para competir com as demais equipes.

${ }^{266}$ SALUN, A. Op. Cit. Nos anexos, apresenta uma carta-compromisso da CBD com Palestra Itália e Corinthians que oferecia a cada clube o valor de 50 contos de réis para que cada equipe disputasse uma partida amistosa contra as equipes cariocas do Botafogo e do Vasco, datado de 1 de dezembro de 1934. Também apresenta a carta de fiança oferecida pela CBD ao Corinthians no valor de 50 contos de réis, datada de 5 de dezembro de 1934.
} 
de 1935 e 1941, a Liga Bandeirante de Futebol adotou diversos nomes: Liga Paulista de Futebol - não confundir com a extinta Liga do início do século -, em 1935; Liga de Futebol Paulista, em 1936; Liga de Futebol do Estado de São Paulo, em 1938; e Federação Paulista de Futebol, em 1941.

O campeonato de 1935 gerou apenas 151 contos de renda para as equipes que dele participaram. ${ }^{267}$ Os jogadores que não conseguiram contratos no exterior partiam para o Rio em busca de novas e melhores oportunidades. Durante toda a década, os times de São Paulo também perderam seus talentos para os times do Rio de Janeiro. A situação financeira das duas Ligas era caótica e a APEA teve seus bens penhorados na justiça, em 1937, para o pagamento de uma indenização após o desligamento do C.A. Santista. As taças da entidade foram utilizadas para o pagamento da dívida. Corinthians e Palestra Itália, no entanto, com o patrocínio da CBD, organizaram e participaram de uma série de jogos amistosos internacionais contra Boca Juniors e River Plate, ao lado de equipes do Rio de Janeiro, reeditando a estratégia da APEA, em 1914, para angariar dinheiro e prestígio e liquidar com a Liga oponente. A nova Liga e seus clubes conseguiram, dessa maneira, minimizar a crise financeira e se renovar continuamente, mesmo com o assédio carioca ou estrangeiro aos jogadores.

A reestreia do São Paulo em 1936 e o ingresso de outras equipes oriundas da APEA no campeonato organizado pela Liga Paulista de Futebol trouxeram o público de volta aos campos da LPF ${ }^{268}$ e esvaziaram definitivamente a APEA. Aos poucos, as demais equipes começaram a migrar para a LPF e, em 1937, a APEA desaparecia.

Portanto, mesmo com a desistência do Paulistano, em 1929, as cisões dentro das ligas e as confusões entre os dirigentes, agora de equipes eminentemente populares, continuaram até 1941, quando pelo decreto-lei n. ${ }^{\circ} 3.199$, o Governo Federal criou o Conselho Nacional de Desportos, CND, que disciplinou e padronizou o nome das ligas nos Estados, adotando o termo Federação de Futebol para todas as entidades regionais ligadas ao futebol, separou os demais esportes da CBD pela criação de federações especializadas, o que, na prática, já vinha ocorrendo durante os anos 1930, e obrigou a adoção do profissionalismo por todas as Federações que se dedicavam ao futebol nos Estados.

\footnotetext{
${ }^{267}$ MAZZONI, T. Op. Cit. Pág. 259. Em todo o campeonato.

${ }^{268}$ MAZZONI, T. Op. Cit. Pág. 265. E pela primeira vez em São Paulo, a renda de uma partida superou a marca dos 100 contos de réis.
} 
$\mathrm{Na}$ atualidade, muitos dirigentes esportivos se colocam contrários a qualquer iniciativa de profissionalizarem a administração de seus respectivos clubes, departamentos de futebol e federações, ${ }^{269}$ assim como criticam a extinção da Lei do Passe, que só aconteceu no final dos anos 1.990 em decorrência de pressões externas ao universo do futebol. ${ }^{270}$ As evidências apontam para a existência de problemas semelhantes aos que marcaram as relações com os jogadores no início do século XX, tais como formas de remuneração extra-oficial que fogem ao fisco e, muitas vezes, se confundem com corrupção.

Com a inauguração do Pacaembu, em 1940, e a consolidação do profissionalismo pela atuação do CND, os dirigentes do futebol de São Paulo encontraram novas formas de ampliar a renda e a presença dos torcedores em seu principal estádio, estimulando a rivalidade entre torcedores e a organização de torcidas uniformizadas, da mesma maneira que consolidaram suas memórias, adequando-as com seus respectivos interesses dentro dos clubes ou da Federação Paulista de Futebol, pela criação de mitos de fundação das equipes, do apagamento de outras memórias e da restrição ao acesso aos documentos dos clubes, ou com ideias como a do trio de ferro formado por Corinthians, Palestra Itália e São Paulo.

Nesta parte do trabalho, verificamos como se deu a gênese do atual São Paulo Futebol Clube. Descortinar este processo nos permitiu compreender como, na década de 1930, os clubes de futebol de São Paulo começavam a se organizar dentro das estruturas já citadas, comparadas por Damatta com o formato de um cometa, como reagiram ao processo de profissionalização implantado nas décadas de 1930 e 1940, e como se confrontaram em busca de espaço e visibilidade entre os torcedores. Conseguimos perceber como se construiu esse imaginário de clube de elite que envolve o atual São

\footnotetext{
${ }^{269}$ SALUN, A. Op. Cit. Pág. 185. Em depoimento ao autor, Juca Kfouri afirma que "Com o advento do futebol e sua transformação em uma mercadoria altamente lucrativa, chegamos em um momento que não podemos concordar que amadores estejam na direção dos clubes, na gestão das federações etc. Eu sempre ponho os amadores entre aspas porque, na verdade, o amadorismo da nossa gestão só interessa a uma parte: o lado dos amadores que não são cobrados profissionalmente, que vivem do futebol, que enriquecem fabulosamente à custa do futebol e que levam os clubes à ruína".

${ }^{270}$ Alguns dos jogadores brasileiros renomados da atualidade ganharam seus passes na justiça, como o atacante Ronaldinho Gaúcho. Na mesma ocasião, o São Paulo Futebol Clube vendeu seu principal astro, o meia Kaká, por um valor abaixo do esperado porque, no ano seguinte, o jogador ganharia passe livre, em decorrência da abolição da Lei do Passe e deixaria o clube sem render um mísero centavo. Para uma melhor compreensão dos problemas decorrentes da Lei doe Passe para os jogadores, ver FLORENZANO, J.P. Afonsinho \& Edmundo. A rebeldia no futebol brasileiro. São Paulo, Musa, 1998.
} 
Paulo Futebol Clube: com o apagamento de algumas memórias, relatos e eventos da trajetória tricolor.

O imaginário que envolve a equipe do São Paulo Futebol Clube o descreve como a equipe mais competente e bem-sucedida do futebol brasileiro. Segundo esses relatos, o clube é a mais moderna, eficiente e profissional equipe de futebol do País. E essa situação é natural em decorrência da ancestralidade do clube, que, fundado por remanescentes do Paulistano, herdou a suposta eficiência que caracterizou o futebol do Paulistano nas primeiras décadas do século XX.

Como as disputas entre dirigentes e clubes pelo controle do futebol paulistano geraram diversas cisões, essas permitiram o aparecimento de várias ligas e a ascensão de times de origem popular aos campeonatos organizados pelas principais entidades, e nesse contexto, os clubes de elite de São Paulo desistiram do futebol oficial ou profissional, entre 1929 e 1941.

Em todas as cisões que acometeram o futebol de São Paulo, o aspecto financeiro ou de negócio da atividade futebolística e dos clubes envolvidos foi prejudicado pela queda na qualidade dos espetáculos oferecidos e o consequente desaparecimento do público pagante das arquibancadas. Em abril de 1935, A Gazeta Esportiva explicitava esta situação:

"Ou alguém acaba com o dissídio do futebol ou o dissídio acaba com o futebol. Isso é indiscutível. Quem hontem esteve no parque Antarctica, não pôde deixar de externar-talvez pela centésima vez-essa opinião. O que se está passando no association paulista - carioca, para não dizer brasileiro, é coisa supinamente ridícula. Ridícula e desaforada. Tão desaforada, que o grosso do público há muito desertou dos campos do esporte que... foi rei, mandando-o às favas, e com carradas de razão... Não estamos exagerando os factos. É isso mesmo. Não há mais ordem, disciplina, nem consideração ao público pagante. Este vae a um campo futebolístico para ser logrado, para se aborrecer com os horríveis espetáculos que lhe são offerecidos, dando-se ainda por feliz quando taes espetáculos não terminam em pancadaria, ou pela metade. Não é possível aturar esta situação por mais tempo. Já é demais."271

Se as estratégias utilizadas pelas equipes e dirigentes implicavam o enfraquecimento ou fechamento das equipes das ligas rivais, traziam oportunidades para

\footnotetext{
${ }^{271}$ Ou o futebol acaba com a scisão, ou esta acabará com o futebol! A Gazeta Esportiva, 22/04/1935. Pág.
} 4. 
novas equipes disputarem os campeonatos ou possibilitavam o reaparecimento de equipes que já tinham desistido do futebol. Entre 1913 e 1917, algumas equipes varzeanas despontaram nos Campeonatos Paulistas organizados pela APEA e pela LPF. Entre 1926 e 1930, algumas equipes do interior de São Paulo tiveram a mesma oportunidade. Mas as cisões também implicavam o desaparecimento de algumas equipes. Na cisão de 1913/1916, o Americano, a equipe mais forte de São Paulo naquele contexto, também se enfraqueceu e desapareceu alguns anos depois.

Ao mesmo tempo, em alguns clubes paulistanos, o desenvolvimento das atividades futebolísticas criava certo antagonismo entre sócios: uns pensavam esses clubes como ambientes excludentes, fechados e exclusivos para os associados e outros advogavam o desenvolvimento do futebol como atividade rentável, algo que implicava a abertura dos espaços sociais para os chamados sócios militantes, aceitos no clube não pela condição social ou origem abastada, mas por suas habilidades esportivas, situação esta existente no Club Athlético Paulistano, no final da década de 1920, e no Palestra Itália e no Germânia, no início dos anos 1930.

Entre 1929 e 1941, diante de duas cisões que causaram crises econômicas profundas em todos os clubes, diversas equipes surgiram, fundiram-se e desapareceram. Uma leitura rápida nos periódicos da época permite perceber essa dinâmica. Clubes que já tinham abandonado o futebol reapareceram com nomes trocados e logo desapareceram. ${ }^{272}$ Outros surgiram de cisões internas dos clubes ou dos espólios de clubes que fechavam. ${ }^{273}$ Mesmo o Corinthians, diante da crise que se abateu sobre o futebol de São Paulo, sofreu uma cisão protagonizada por alguns de seus dirigentes, que fundaram um novo clube denominado Piratininga, ${ }^{274}$ que disputou o campeonato organizado por uma nova Liga Amadora, a partir de 1935, com os jogadores veteranos remanescentes do Paulistano.

Clubes tradicionais abandonaram os gramados. Internacional e Germânia não chegaram a disputar o campeonato de $1933^{275}$ e a memória sobre o período consolidou a

\footnotetext{
272 O reapparecimento do Antarctica F.C. e a sua imediata troca de denominação para C. A. Paulista. $A$ Gazeta Esportiva. 13/05/1935. Pág. 4.

273 O E. C. Independente successor do S. Paulo F. C. na APEA. A Gazeta Esportiva. 15/04/1935. Pág. 5.

${ }^{274}$ Um novo clube que surge? A Gazeta Esportiva. 08/04/1935. Pág. 4. Alfredo Schurig, Wladimir Toledo Piza e Gennaro Rodrigues patrocinaram a fundação desta equipe.

${ }^{275}$ RIBEIRO, R. O caminho da bola. Op. Cit. Pág. 383. As fichas completas dos jogos dos campeonatos estão nesta obra.
} 
ideia de que eses clubes se retiraram por não concordarem com o profissionalismo no futebol. Mas essas narrativas não explicam que, tanto quanto a profissionalização, as cisões representaram a inviabilidade financeira para muitas dessas equipes. O próprio Internacional, por exemplo, um dos clubes pioneiros nos esportes em São Paulo, desapareceu nesse contexto.

Pela leitura de pequenos textos encontrados em jornais, percebemos que a questão financeira estava no centro da crise. Ao descrever a trajetória do Ipiranga em uma nota celebrativa de aniversário, A Gazeta Esportiva mostra como a crise levara à ruína diversos clubes paulistanos naquela época. ${ }^{276} \mathrm{Em}$ abril de 1934, o São Bento anunciou que não participaria do campeonato. A nota informa que "o S. Bento solicitou da APEA licença para não disputar o campeonato deste anno, tendo a mesma lhe sido concedida. A crise que assoberbou o alvi-celeste nestes últimos tempos, com a sahida de alguns de seus principais dirigentes e a perda da maioria de seus jogadores, teria sido o motivo que o levou a dar esse passo extreme." ${ }^{277}$ Em março de 1935, o mesmo periódico anuncia a volta da equipe, ${ }^{278}$ que não se concretizou. Em outra nota, explicita como o futebol do Rio de Janeiro se agigantara em técnica e organização quando comparado ao futebol de São Paulo, no contexto de disputas e cisões da década de $1930 .^{279}$

Desde 1928, os jogadores exerciam pressão pela profissionalização do futebol e chegaram a fundar a Liga Paulista de Profissionais de Futebol, que, por falta de apoio dos clubes e ligas, rapidamente desapareceu. ${ }^{280} \mathrm{O}$ processo de especialização que ocorria desde a década de 1910 alcançava patamares que obrigavam as equipes e ligas a profissionalizar o espetáculo porque a concorrência entre elas e o público que acorria aos campos, assim o exigia. O problema era o mesmo desde os anos 1910. Quem comandaria os espetáculos e obteria os dividendos?

\footnotetext{
${ }^{276}$ O Ipiranga faz hoje 32 anos! A Gazeta Esportiva. 11/07/1938. Pág. 6. "O C. A. Ipiranga comemora hoje a passagem do seu $32 .^{\circ}$ ano de vida. É uma data histórica do nosso esporte, pois que assinala mais uma etapa brilhantemente vencida pelo mais velho clube do nosso principal futebol, cheio de tradições e sacrificios. $O$ association paulista tem nele a sua bandeira, o mais valioso testemunho da sua evolução. Enquantos outros se deixaram arrastar pelo vendaval da crise, o Ipiranga não encontrou obstáculos que se opuzessem à sua vontade firme e inquebrantável e aí está sempre grande na sua modéstia, a figurar como um símbolo da história deste nosso futebol tão glorioso e tão infeliz e do qual o alvi-negro nada mais foi do que um dos seus mártires."

277 O São Bento não disputará o campeonato deste anno. A Gazeta Esportiva. 02/04/1934. Pág. 4.

${ }^{278}$ A volta do São Bento. A Gazeta Esportiva. 11/03/1935. Pág. 7.

${ }^{279}$ Algo alarmante... A Gazeta Esportiva. 31/10/1938. Pág. 6.

${ }^{280}$ MAZZONI, T. História do futebol no Brasil. Pág. 207.
} 
Ao discutir o momento em que o Paulistano abandonou o futebol oficial e liberou seus jogadores para outras equipes, Ribeiro lembra que Antonio Prado Jr. anunciou a decisão do clube após manifestação oficial da CBD, reconhecendo a APEA como a única entidade credenciada para representar o futebol de São Paulo. Desde 1926, o Paulistano injetara 50:000\$000 na criação da Liga Amadora de Futebol e tentara organizar campeonatos e partidas amistosas com equipes estrangeiras e de outros Estados do Brasil. ${ }^{281}$ Todas as equipes que acompanharam o Paulistano na cisão tiveram problemas econômicos. Ao término de 1929, algumas conseguiram se manter, outras se encontravam em estado pré-falimentar, como a A.A. das Palmeiras. ${ }^{282}$ Nenhuma delas, no entanto, teve condições de acompanhar o processo de profissionalização e os valores envolvidos, ou uma nova crise decorrente de nova cisão.

Mazzoni informa que, em 1929, os clubes que aderiram à LAF forçaram a fusão com a APEA, exceto o Paulistano, que, aparentemente, desistiu do futebol naquele contexto, porque seus dirigentes estavam cansados da disputa. ${ }^{283} \mathrm{~A}$ assinatura entre todos os dirigentes do acordo que pacificou o futebol paulistano ocorreu na sede de $A$ Gazeta, em São Paulo, em 21 de dezembro daquele ano. O papel de Casper Líbero foi fundamental, tanto que, em janeiro de 1930, a diretoria da A.A. das Palmeiras o transformou em presidente de honra da agremiação. ${ }^{284}$

Foi no contexto em que o Paulistano anunciava o fechamento de seu departamento de futebol e a A.A. das Palmeiras encontrava-se em uma situação de penúria, que surgiu a ideia de fundir os remanescentes do Paulistano, isto é, todo o departamento de futebol do clube com a A.A. das Palmeiras, em janeiro de 1930. O próprio Mazzoni deixou seu testemunho:

"Sabia-se que o Palmeiras, já há muito tempo em decadência, havia corrido o risco de perder o seu campo da Floresta; sua situação era difícil, por isso imediatamente nasceu a ideia de se encontrar uma fórmula que indicasse o modo mais prático de fazer surgir um clube que substituísse o Paulistano no campo de

\footnotetext{
${ }^{281}$ RIBEIRO, R. O caminho da bola. 100 anos de história da FPF. Vol I. Págs. 330 e 331.

${ }^{282}$ Retornando... Augusto Castro Leite, 2. ${ }^{\circ}$ thesoureiro da A.A. Palmeiras, volta á atividade esportiva - O que s.s. nos contou sobre o tradicional núcleo da Floresta. A Gazeta Esportiva, 24/11/1929. Pág.15.

${ }^{283}$ MAZZONI, T. Op. Cit. Pág. 219. O autor não informa o que cansava os clubes. Mas o depoimento de Augusto Castro Leite, 2. ${ }^{\circ}$ tesoureiro da A.A. das Palmeiras, acerca da crise Palmeirista, no final de 1929, é esclarecedora. Idem. Ibidem.

${ }^{284} \mathrm{O}$ dr. Casper Líbero, diretor da Gazeta, foi acclamado presidente honorário do (sic) Palmeiras. A Gazeta Esportiva. 06/01/1930. Pág. 5.
} 
futebol. A corrente futebolística do alvi-rubro pôs-se em ação e encontrou o Palmeiras disposto a uma união que originasse o novo clube. A princípio, entrou nas cogitações também o São Bento, tendo havido as primeiras dermaches (sic) a respeito, mas como não vingaram alguns pontos de vista do clube alvi-celeste, resultou na sua desistência de participar na fundação do novo grêmio."285

Em 27 de janeiro de 1930, A Gazeta Esportiva anunciava a fundação do São Paulo Futebol Clube, sem o concurso do São Bento ${ }^{286}$. Em três de fevereiro, o mesmo periódico informa que o primeiro treino da equipe havia sido um grande sucesso, com a presença de quase cinqüenta jogadores. ${ }^{287}$ A nota é interessante por alguns motivos:

"Hontem na Floresta, effectuou-se o primeiro treino dos elementos do São Paulo (ex-Palmeiras) para a escolha dos quadros que deverão tomar parte no campeonato paulista do corrente ano. A assistência foi enorme. Alguns milhares de aficionados abarrotaram as dependências da velha praça de esportes da Ponte Grande. E enorme foi também o número de jogadores presentes promptos para o esperado exercício... Nada menos de 49! No final do treino, assignaram inscripção para o novel conjunto nada menos de 28 futebolístas!"288

O periódico se refere à nova equipe como o ex-Palmeiras, não como o exPaulistano. O volume de jogadores que acorreram para a peneira foi enorme, provavelmente maior que a soma dos quadros de Palmeiras e Paulistano. Naquela ocasião, foram eleitos os diretores e o conselho deliberativo, que era constituído por nove membros oriundos de cada equipe. Além de Edgard de Souza Aranha, primeiro presidente, foram eleitos Alberto Caldas, $1 .^{\circ}$ vice-presidente, Gastão Rachou, 2. ${ }^{\circ}$ vice, Dr. Benedicto Montenegro, 3. ${ }^{\circ}$ vice, Dr. Luiz de Oliveira Barros, 1. ${ }^{\circ}$ secretário, Dr. José Martins Costa, 2. ${ }^{\circ}$ secretário, João B. da Cunha, tesoureiro, Dr. Caio Luis Pereira de Souza, 2. ${ }^{\circ}$ tesoureiro. O conselho fiscal foi formado por Dr. Samuel Toledo Filho, Nevio Barbosa e Raphael Salles Sampaio. O conselho deliberativo foi formado por João Mesquita Filho, Nevio Barbosa, Gastão Rachou, Alberto Caldas, Augusto Castro Leite, Luiz Augusto Pereira de Queiroz, Marcello Paes de Barros, Luiz Marcondes de Moura, Leonel Benevides de Rezende, Ariosto Ferraz, prof. Sérgio Meira, Rubens Salles,

\footnotetext{
${ }^{285}$ MAZZONI, T. Op. Cit. Pág. 221.

${ }^{286}$ O S. Paulo F. C. está definitivamente fundado, mas sem o concurso do S. Bento. A Gazeta Esportiva. 27/01/1930. Pág. 4.

${ }^{287}$ O primeiro treino do S. Paulo constituiu um sucesso. A Gazeta Esportiva. 03/02/1930. Pág. 4.

${ }^{288}$ Idem nota 288.
} 
Arnaldo Alves da Motta, Manuel Carlos Aranha, Mario da Cunha Bueno, Luiz Fernando do Amaral, Firmiano de Moraes Pinto Filho e João de Oliveira Barros. ${ }^{289}$

A Gazeta Esportiva informa que o campo a ser utilizado pela nova equipe era o existente na Chácara da Floresta, após a realização de obras que permitissem o concurso de até cerca de quinze mil espectadores nas arquibancadas. ${ }^{290}$ Evidentemente, além da junção de forças entre A.A. das Palmeiras e os jogadores do Paulistano, a reunificação trouxe novo entusiasmo aos aficionados por futebol em São Paulo, razão pela qual os organizadores da nova equipe pretendiam a reforma da Chácara da Floresta.

Nem todos os jogadores do Paulistano aderiram imediatamente ao novo clube. Os primeiros jogadores inscritos pelo São Paulo Futebol Clube e aprovados pela APEA foram Francisco Abate, José Miguel Gneco, Antonio Carlos Seixas, Joaquim da Cunha Bueno Netto, João Alvares Botelho de Miranda, Nelson Alves, Paschoal Ângelo, Scavazza, Nestor de Almeida, Olavo Leonel de Barros, Waldemar Godoy, Miguel dos Santos Júnior, Alfredo Teixeira, Décio Alves de Lara e Ruben Marcondes Trigo. ${ }^{291}$

Na mesma edição, o periódico informa a realização de um leilão para garantir o passe de um famoso jogador. A nota ilustra o que colocamos em capítulo anterior e traz uma informação nova. Os dirigentes já realizavam negociações do passe dos atletas com vistas ao lucro.

“Ainda há bem poucos dias esteve na baila, famoso chutador. À margem de seu ambicionado concurso correram verdadeiras lendas... Mas, é facto, o famoso foi maior... víctima. Tantos eram os indivíduos que andavam atraz de sua inscripção que passára dias e dias de completo desassocego. - Damos-lhe tanto! - Dobramos a parada... - Garantimos-lhe tal emprego! - Traga todas as propostas que receber que daremos mais que a melhor... E por essa cravelha, eram afinados os cantos das sereias, desses sórdidos laçadores, que infestam nosso futebol... A propósito do passe: entre nós certo popular grêmio não se faz de rogado quanto à sua concessão. Seu presidente é positivo. A quem queira ouvir diz sem rebuços: damos o passe que solicitarem. É apenas entrarem em entendimentos com o thesoureiro do clube. (Devolver o quantum, o tal recebera pela inscripção. Ainda há dias foram devolvidos $750 \$$, sendo que $150 \$ 000$ foram de... juros!).” 292

\footnotetext{
289 O S. Paulo F. C. está definitivamente fundado, mas sem o concurso do S. Bento. A Gazeta Esportiva. 27/01/1930. Pág. 4.

${ }^{290}$ O primeiro treino do S. Paulo constituiu um sucesso. A Gazeta Esportiva. 03/02/1930. Pág. 4.

${ }^{291}$ Os primeiros inscritos para o S. Paulo. A Gazeta Esportiva. 16/02/1930. Pág. 5.

292 "Vendeu-se". A Gazeta Esportiva. 16/02/1930. Pág. 6.
} 
Em 23 de fevereiro de 1930, o periódico anuncia a inscrição de Friedenreich pelo São Paulo. ${ }^{293}$

Em 1931, o São Paulo Futebol Clube, que depois ficou conhecido como São Paulo da Floresta, sagrou-se campeão paulista. Mas o êxito nas arquibancadas veio antes, quando muitos dos simpatizantes de A.A. das Palmeiras e Paulistano se transformaram em simpatizantes do tricolor. Notícia em A Gazeta Esportiva, em 1941, indica que, por alguns anos, as rendas obtidas pelo São Paulo da Floresta foram muito superiores às obtidas pelo atual São Paulo Futebol Clube. ${ }^{294}$

De fato, para aqueles que admiravam o Paulistano, o São Paulo da Floresta despontava como herdeiro de toda uma tradição fundada nos tempos do Velódromo, enriquecida por uma das mais brilhantes trajetórias do futebol paulistano dos tempos do amadorismo, uma vez que o Paulistano conquistou onze títulos: pela LPF - 1905, 1908, 1913; pela APEA - 1916, 1917, 1918, 1919, 1921, 1926; pela LAF - 1927, 1929. A soma dos títulos e com a tradição da A.A. das Palmeiras reforçou este imaginário interessante para os torcedores, mas melhor ainda para os dirigentes da nova equipe, que demandavam essas comparações para se cristalizarem no Campeonato Paulista nos idos de 1930 e atraírem público e renda. $^{295}$

\footnotetext{
${ }^{293}$ Jogadores inscriptos na APEA. A Gazeta Esportiva. 09/03/1930. Pág. 2.

${ }^{294}$ Palestra - Corinthians - São Paulo. Os clubes que mais rendas produzem. A Gazeta Esportiva. 19/07/1941. Pág. 12.

${ }^{295}$ FLORENZANO, J. P. A democracia corinthiana. Pág. 404. O autor, ao discutir o torcer popular, afirma que "a rigor, não há nada de errado em acalentar o sonho de ser campeão mundial, nem tampouco depositar confiança na capacidade da equipe em concretizá-lo. Além disso, convém não reduzir o significado da conquista esportiva à mera questão material, traduzindo-a em termos dos lucros econômicos advindos com o êxito. Decerto, não foi o futebol-empresa o inventor da obsessão pela vitória.
}

6. Figurinhas do time do C. A. Paulistano na década de 1920 das Balas Sportman. (Coleção particular de Marcelo Dentello).
TAR MAIOR WUMERO DE EHVOLTORIOS GANHARA RICA TACA

Grande Manulaclora Srasileira de Bonbons S/A RUA DO GAZOMETRO . 33. 35 e 37 Predio proprio-Caixa Postoi, 1927 - Tel. 8-0758 SAO PAULO

Frend - C. As Pavlisteno IHADRTANTE-dentro dos envoltories capr choszmente confeccionzdos silo encontrados distinctivos de celluloide os quees tern a phoegraphia de tedos os moihores logedores (usm-

\section{BALAS SPORTMAN}


Para os torcedores, o imaginário vitorioso das duas equipes que saíam de cena fazia parte do contexto de rivalidades com corintianos e palestrinos e foi reelaborado de acordo com o contexto, servindo de mito de origem para o novo clube. O São Paulo da Floresta, desde então, era o herdeiro do Paulistano e quase não se fala da A.A. Palmeiras. Para os dirigentes são-paulinos, essa foi uma estratégia mercadológica fundamental para angariar os simpatizantes das duas antigas equipes, gerar boas rendas e desenvolver as atividades da nova agremiação, mesmo que o Paulistano continuasse a existir nas disputas de outros esportes.

Não foi apenas o imaginário de ser da elite que o novo clube herdou. A dívida da A.A. das Palmeiras veio junto e, com a ajuda da APEA, chegou-se a uma renegociação para que fosse paga apenas em 1934. ${ }^{296}$ Em novembro daquele ano, a dívida foi rolada por mais dois anos e a estrutura administrativa do novo clube mostrou-se fechada, articulada em um grupo pequeno de conselheiros, dirigentes e fundadores que entendiam o clube como posse particular de cada um deles e não permitiam que novos dirigentes participassem das decisões. ${ }^{297}$

Por ocasião da reunião que decidiu o fechamento do São Paulo da Floresta, esse grupo restrito de dirigentes e associados, pela A Gazeta de "casta de privilegiados creada no seio tricolor desde sua fundação", que continha em suas mãos dezenas de procurações, fechou o clube por conta de seus estatutos. ${ }^{298}$ Naquela ocasião, apenas quatro dirigentes conseguiram vencer um grupo de quase quarenta pessoas, o chamado Grêmio Tricolor, que tentava, na justiça, manter o clube em funcionamento desde que se anunciara a fusão com o Tietê. ${ }^{299}$

Algumas semanas antes, A Gazeta discutia a questão do São Paulo da Floresta em um artigo no qual afirma

Antes de adquirir a forma moderna do esporte, o jogo já colocava em jogo o êxito, já mobilizava a paixão necessária para obtê-lo, assim como a honra e o prestígio que o acompanham”.

296 Em plena guerra futebolística. A acção judicial da APEA contra o São Paulo F. C. A Gazeta. 05/04/1935. Pág. 10

${ }^{297}$ A verdade sobre a vida do S. Paulo F. C. A Gazeta. 02/05/1935. Pág. 9.

${ }^{298}$ A Assembléia dos 200. Os autores da fusão tiveram ganho de causa à custa de procurações. A Gazeta. 15/05/1935. Pág. 8.

${ }^{299}$ Foi illegal a fusão São Paulo - Tietê. A Gazeta. 03/05/1935. Pág. 9. 
"Os seus associados que fizeram o possível para impedir o desaparecimento do seu querido clube como esteve ameaçado - em consequência da anarchia em que foi atirado o futebol paulista, por capricho e interesses facciosos de meia dúzia de clubistas incorrigíveis - resolveram fundar um grupo tricolor cujas finalidades já foram publicadas. Pretende-se melhorar o ambiente esportivo do clube, approximando os sócios dos jogadores, collaborar com os diretores, trabalhar, enfim, para que o São Paulo F.C. não seja apenas um clube dos que têm o privilégio de serem fundadores, que são várias pessoas... O regimen do são Paulo F. C. não é próprio para um clube de esporte no Brasil. Na Inglaterra pode ser." 300

Pelo artigo, vimos que existia no São Paulo da Floresta um distanciamento entre sócios, jogadores e torcedores, nos moldes dos clubes de elite, embora sua torcida já fosse das maiores da cidade. A divisão que existira entre os sócios do Paulistano e causara a desistência do clube em relação ao futebol profissional continuava a existir no São Paulo da Floresta. E isso causava problemas de toda ordem para o funcionamento de um time de futebol dentro de um sistema competitivo e profissional. Naquele início de 1935, para torcedores e associados, a questão era clara. O clube teria que se adaptar à nova realidade se quisesse disputar os principais campeonatos de futebol e ser campeão, ou, então, teria que acabar com o futebol, algo inaceitável para os torcedores e parcela dos sócios.

Os próprios jogadores do São Paulo da Floresta percebiam o que acontecia e debandaram em busca de outros clubes, em outros Estados ou mesmo países. No limite, fundaram uma nova equipe, o E. C. Independente. ${ }^{301} \mathrm{O}$ próprio Friedenreich encerrou sua carreira em algumas semanas atuando pelo Santos F. C. em uma série de amistosos internacionais que o clube praiano realizou em Porto Alegre. ${ }^{302}$

Quando o São Paulo da Floresta se fundiu com o Clube de Regatas Tietê, o último clube do futebol paulistano que podemos chamar de elite desapareceu dos campeonatos, assim como o seu campo de futebol na Chácara da Floresta, rapidamente incorporado pelo novo Tietê - São Paulo. ${ }^{303}$

\footnotetext{
${ }^{300}$ Para que o São Paulo seja um clube popular. A Gazeta. 31/01/1935. Pág. 8.

${ }^{301}$ De surpreza em surpreza... A Gazeta. 26/03/1935. Pág. 8.

302 43:000\$000. O successo da estreia do Santos e de Fried, em Porto Alegre. A Gazeta. 14/05/1935. Pág. 10.

${ }^{303}$ Foi illegal a fusão São Paulo - Tietê. A Gazeta. 03/05/1935. Pág. 9. O São Bento não sobreviveu ao ano de 1935.
} 
A torcida tricolor que era profundamente popular, no entanto não aceitou o fato e, organizada por um grupo denominado Grêmio Tricolor, só sossegou com a fundação de um novo clube, em dezembro de $1935,{ }^{304}$ com o mesmo nome, mas com estruturas sociais idênticas às existentes no Corinthians e no Palestra Itália e que se assemelhavam à metáfora do cometa e sua calda, citada por Damatta.

Durante os meses que antecederam a fundação do novo São Paulo Futebol Clube, o Grêmio Tricolor liderou passeatas, protestos e uma ação judicial contra o fechamento do antigo São Paulo da Floresta. As manifestações foram registradas pelos periódicos ao longo do ano de 1935 e atestam a força da torcida são-paulina naquele contexto e diferente do imaginário elitista que circundava a equipe da Floresta ou o atual São Paulo, e completamente independente daquela parcela dirigente que preferiu fechar o clube.

\subsection{São Paulo da Floresta e São Paulo Futebol Clube. A mesma equipe ou times diferentes?}

"Muitas outras coisas, hoje engraçadas, aconteceram conosco. Numa certa ocasião, o dono da casa na Praça Carlos Gomes, onde foi a primeira sede do São Paulo, passou um cadeado no portão e nos impediu de entrar porque estávamos com dois meses de atraso no aluguel. Nós tínhamos que dar um jeito naquela situação e eu não tive dúvidas: fui para a casa dele, na Vila Pompeia, e, às três horas da madrugada, acabei acordando toda a vizinhança, gritando debaixo da janela para que ele viesse até a rua para nos entendermos. Ele acabou saindo e, ao invés de uma briga, tivemos trabalho dobrado tentando convencê-lo com uma conversa calma, mas conseguimos.",305

"O São Paulo Futebol Clube, fundado na cidade de São Paulo, onde tem foro e sede, em 16 de dezembro de 1935, preservador das glórias e tradições do São Paulo Futebol Clube, da Floresta, o qual foi fundado em 25 de janeiro de 1930 e extinto em 14 de maio de 1935, é uma Entidade de Prática Desportiva, constituída na forma de associação civil sem fins econômicos com prazo de duração indeterminado e que tem total autonomia de organização e

\footnotetext{
${ }^{304}$ O Grêmio Tricolor fundou o S. Paulo Futebol Clube. A Gazeta. 17/12/1935. Pág. 13.

305 PIMENTEL, Odair e PENNA, Maysa. "Valeu a pena". São Paulo Futebol Clube 1935 - 1980. Págs. 40 e 41.
} 
funcionamento, de conformidade com o inciso I do artigo 217 da Constituição Federal da República Federativa do Brasil de 05/10/1988."306

A pesquisa nos mostrou facetas interessantes e pouco discutidas sobre as identidades do futebol em São Paulo. O aparecimento de times com o nome dos bairros de origem não foi uma prática usual no futebol oficial e profissional em São Paulo, como mencionamos anteriormente, mas entre 1894 e 1942, encontramos diversas equipes que adotaram o nome da cidade: São Paulo Athletic Club (SPAC ou Clube dos Ingleses), São Paulo Railway (SPR ou Nacional, a partir dos anos 1940) e pelo menos três equipes intituladas São Paulo Futebol Clube. Uma delas, com sede no bairro da Bela Vista, equipe na qual despontou Friedenreich no final dos anos 1910, disputou com o Corinthians a chance de participar da Liga Paulista de Futebol, em 1913. Uma segunda surgiu em janeiro de 1930, da fusão das equipes do Paulistano e da A.A. das Palmeiras, campeã em 1931, e ficou conhecida como São Paulo da Floresta, pois mandava seus jogos na Chácara da Floresta. A outra, o atual São Paulo Futebol Clube.

Em nossos dias, os memorialistas e historiadores tricolores se debruçam sobre duas grandes polêmicas sobre o clube e de como se deu sua fundação. É o São Paulo Futebol Clube herdeiro das tradições futebolísticas do Paulistano? É o clube a retomada do antigo São Paulo da Floresta? Por se tratar de um clube que se constituiu mais tarde, os periódicos da época acompanharam e publicaram um volume muito maior de informações se compararmos com as relacionadas às fundações de Corinthians e Palestra Itália. Contraditoriamente, o volume de material publicado pelo próprio clube é relativamente menor. No interior do clube, duas correntes de historiadores e memorialistas divergem sobre como se deu a fundação do clube.

Em março de 1985, A Gazeta Esportiva publica um dossiê celebrativo do 50. aniversário do clube, intitulado São Paulo F. C. 50 anos. Jubileu de ouro em formato de encarte. Informa o periódico que

"São 50 anos de história, de muita fé e amor a um clube que nasceu grande. Tudo começou na sala do prédio 9-A da Rua 11 de Agosto, ao lado do antigo Palácio da Justiça, a poucos metros do marco oficial da cidade, no dia 16 de novembro de

\footnotetext{
306 Artigo 1. ${ }^{\circ}$ do Estatuto Social do São Paulo Futebol Clube. Documento fornecido por Domingos D’Ângelo, conselheiro do São Paulo Futebol Clube, que cedeu uma cópia da primeira página do atual estatuto tricolor.
} 
1935. Era grande o número de pessoas que compareceu àquela primeira assembleia, atendendo a um convite da diretoria do Grêmio Tricolor... Começava a nascer a base do São Paulo Futebol Clube. A primeira fase, de 1930 a 1935, com o São Paulo da Floresta, foi muito conturbada na maior parte de seu período... Foi a época em que a A.A. das Palmeiras, em decadência e ameaçada de perder o campo na Chácara da Floresta, filiada à APEA, e o C.A. Paulistano, com o futebol em extinção, mesmo filiado à LAF, buscavam pacificação entre as duas entidades. Foi, então, que fizeram a fusão, nascendo o São Paulo da primeira fase, sendo eleito presidente o Dr. Edgard de Souza Aranha, no dia 27 de janeiro de 1930, na Praça da República, 28."307

O próprio encarte deixa no ar a dúvida: teriam sido o São Paulo da Floresta e São Paulo Futebol Clube uma só equipe? Recentemente, o São Paulo Futebol Clube chegou a pleitear, junto à Federação Paulista de Futebol, o único título paulista conquistado pelo São Paulo da Floresta, em 1931.

A leitura dos jornais publicados no período mostra que existiu certa confusão sobre o tema. Não foram poucos os artigos encontrados que trataram o atual São Paulo Futebol Clube como um prolongamento do antigo São Paulo da Floresta. Em agosto de 1941, A Gazeta Esportiva traz artigo no qual diz que "o São Paulo F. C., desde os tempos da Floresta, é um clube que sempre contou com um ótimo quadro de reservas, mais conhecidos por segundo quadro." ${ }^{, 308}$ Em 1937, o periódico afirma, após uma vitória tricolor em cima da Portuguesa, que "o quadro tricolor foi digno do S. Paulo da Floresta, vencendo a Portugueza no campo desta." ${ }^{309}$ Após uma vitória contra o Palestra Itália, o mesmo periódico, em manchete de março de 1939, anuncia "Maior que a vitória de 1931...". Segundo a matéria,

"O São Paulo venceu, ontem, o Palestra, em seu campo à Rua da Mooca, como o teria vencido no Parque Antarctica, no Parque São Jorge, em Vila Belmiro, ou onde quer que fosse, porque tinha que vencê-lo, dada a grande e ilimitada chance que levou à luta para triunfar. Estava em melhores condições para vencer, e deu-se até ao luxo como se viu - de colher um sonoro 6 a 0 (seis a zero), contagem essa que, em se tratando de Palestra... parece mais uma história de mil e uma noites... A realidade, porém, colocou essa contagem diante dos olhos daqueles que estiveram presentes à partida e nos ouvidos daqueles que tiveram o expediente de deixar-se ficar em casa e ouvir o rádio relatar o jogo. Com seis a zero, o São Paulo F. C. "júnior" superou, ontem,

\footnotetext{
${ }^{307}$ São Paulo F. C. 50 anos. Jubileu de ouro. A Gazeta Esportiva. 06/03/1985. Pág. 4.

${ }^{308}$ Dos áureos tempos da Floresta. A Gazeta Esportiva. 02/08/1941. Pág. 4.

${ }^{309}$ Muito bem, São Paulo F. C.! A Gazeta Esportiva. 08/03/1937. Pág. 3.
} 
a proeza lendária de seu pai da Floresta, que, em 1931, venceu o grande rival por quatro a zero." 310

Em determinadas ocasiões, o periódico trata o São Paulo Futebol Clube como prolongamento automático do São Paulo da Floresta, em outras tenta vincular um clube ao outro, sem indicar algum tipo de parentesco. Às vezes, deixa transparecer que um clube era diferente do outro.

O fechamento do São Paulo da Floresta em maio de 1935 não foi bem recebido pelos torcedores. A leitura sugere que a própria direção do clube estava profundamente contrariada e dividida com os acontecimentos que marcaram o futebol paulistano, em meados de 1934 e 1935, e não sabia quais atitudes tomar. Mazzoni afirma que o clube se endividara com a montagem de suntuosa sede, razão pela qual seu fôlego financeiro estava limitado. Para piorar, as partidas de futebol não rendiam o suficiente para que o clube obtivesse renda para pagá-la porque o público sumiu dos estádios no final de 1934, início de 1935 . $^{311}$

A razão para tal confusão foi o anúncio de uma nova ruptura liderada por Corinthians e Palestra Itália que acabou com a paz selada em 1930. Financiados pela CBD, os dois clubes abandonaram a APEA, juntaram-se ao Vasco da Gama no apoio à $\mathrm{CBD},{ }^{312}$ criaram uma nova Liga, denominada Liga Bandeirante de Futebol, realizaram jogos amistosos com equipes do Rio de Janeiro e do exterior, e, assim, mantiveram suas rendas com a realização desses jogos no Parque Antarctica e no Parque São Jorge, além de atraírem jogadores de outras equipes. ${ }^{313}$

Havia, de um lado, o sentimento de torcedores e sócios do antigo São Paulo da Floresta. Por outro, os interesses comerciais daqueles que viviam do negócio do futebol e que entendiam a importância das rendas geradas pelo São Paulo da Floresta para o espetáculo do futebol, que vivia sua maior crise econômica. Por conta dessa situação,

\footnotetext{
${ }^{310}$ Maior que a vitória de 1931... A Gazeta Esportiva. 27/03/1939. Pág. 2.

${ }^{311}$ MAZZONI, T. História do futebol no Brasil. Op. Cit. Pág. 257.

${ }^{312}$ MAZZONI, T. Idem. Pág. 252. Chama atenção a iniciativa da CBD de impedir a profissionalização no eixo Rio - São Paulo, já que atingiu aqueles clubes que possuíam as melhores praças desportivas particulares das duas cidades: Palestra Itália e Vasco da Gama. Na prática, com essa iniciativa, a CBD controlava as melhores praças desportivas e mesmo que os clubes com maiores torcidas não aderissem à $\mathrm{CBD}$, não teriam como praticar jogos rentáveis, já que os campeonatos locais estavam desorganizados e sem acesso aos melhores campos.

313 MAZZONI, T. Op. Cit. Pág. 257. Apenas da Portuguesa, Palestra Itália e Corinthians levaram Batatais, Machado, Nico e Brandão (os três primeiros para o Palestra Itália e o último para o Corinthians).
} 
desde a fundação, jornalistas, torcedores e alguns dirigentes tentaram vincular o atual São Paulo Futebol Clube ao São Paulo da Floresta. De fato, diversos fundadores do novo São Paulo F.C. eram oriundos das fileiras do São Paulo da Floresta. Assim como alguns dos fundadores do Palestra Itália eram oriundos do Internacional e do Corinthians. Assim como alguns dos primeiros jogadores corintianos atuavam por outras equipes da várzea. Nem por isso podemos afirmar que Palestra Itália e Corinthians eram ou são a mesma equipe, ou Corinthians e Botafogo do Bom Retiro, uma só equipe.

Na obra intitulada São Paulo Futebol Clube 1935-1980, Pimentel e Penna afirmam que "a história do São Paulo da Floresta é outra. Não deixa de ser um marco, mas foge à conotação do São Paulo Futebol Clube, de 45 anos. A Floresta marca uma passagem muito tumultuada, por cinco anos. O Paulistano cedia os seus atletas e a A.A. das Palmeiras seu campo oficial, na antiga Chácara da Floresta, ao novo clube, que disputou a sua primeira partida na Divisão Superior." 314

O aparecimento do novo São Paulo Futebol Clube foi motivado pela atuação de antigos torcedores do extinto São Paulo da Floresta, que se organizavam no chamado "Grêmio Tricolor". Esses torcedores se juntaram aos conselheiros e dirigentes da antiga agremiação da Floresta que foram contra a extinção da equipe e fundaram uma nova agremiação com o nome da cidade, em quatro de junho de 1935: o Clube Atlético São Paulo. $^{315}$

Segundo A Gazeta Esportiva, a antiga sede do São Paulo da Floresta rapidamente foi incorporada ao patrimônio do Tietê, que promoveu o desmanche das arquibancadas e do campo destinados ao futebol em poucos dias, ${ }^{316}$ enquanto mantinha uma equipe amadora de futebol treinada por Friedenreich, razão pela qual ficaram conhecidos como pupilos de Fried. ${ }^{317}$

Após a fundação do novo São Paulo Futebol Clube, ocorrida em dezembro de 1935, os antigos jogadores do Paulistano, todos veteranos, ainda jogavam futebol e

\footnotetext{
${ }^{314}$ PIMENTEL, Odair e PENNA, Maysa. São Paulo Futebol Clube 1935 - 1980. Pág. 11.

315 PIMENTEL, Odair e PENNA, Maysa. Op. Cit. Pág. 13.

${ }^{316}$ Teria sido embargada a reforma da Floresta? A Gazeta Esportiva. 22/04/1935. Pág. 3. A matéria informa que o clube sequer permitiu a realização dos jogos universitários que estavam programados para a Chácara da Floresta.

${ }^{317}$ O quadro amador do Tietê - S. Paulo obteve outra alta Victória. A Gazeta Esportiva. 16/09/1935. Pág. 5.
} 
disputaram o campeonato organizado por uma liga amadora. Atuaram pelo Piratininga, clube criado por alguns dirigentes corintianos. ${ }^{318}$ Da mesma maneira, o time amador do Tietê continuava em atividade, como podemos perceber por meio de A Gazeta Esportiva. $^{319}$

As fontes sugerem que havia uma disputa pelos torcedores e simpatizantes do antigo São Paulo da Floresta, tanto que o mesmo periódico anunciou, em determinada ocasião, que o clube fundado por ex-jogadores do São Paulo da Floresta e denominado E.C. Independente seria seu sucessor na APEA. Segundo o periodico,

"Ao nascer o E.C. Independente, numa noite destas, no dia seguinte foi dado como... morto. Isso, no entanto, não aconteceu. O novel clube, como se vê, está se constituindo bem, tendo estreado hontem, e vae ter um papel de destaque nas nossas canchas pois tomará o lugar do São Paulo F. C., sempre bem entendido que consiga ter uma direção capaz de lhe dar vida effectiva. O E. C. Independente, segundo é voz corrente, contará após o campeonato brasileiro com todos os elementos do tricolor. Os que ainda não haviam deixado o clube da Floresta e os azes que estão prestando serviço à Liga Paulista adherirão logo que terminar o campeonato brasileiro... Assim, virtualmente, o famoso esquadrão tricolor voltará à actividade com a denominação de Independente, no seio da APEA... Quanto ao S. Paulo F. C., o seu destino já está traçado: praticará doravante todos os esportes, inclusive o futebol amador, fundido com o Tietê. Por um accordo havido, a denominação dos dois clubes unidos será São Paulo Tietê." $" 320$

O depoimento de Frederico Menzen, segundo presidente do São Paulo Futebol Clube e sócio número 1, é esclarecedor sobre dois aspectos. Por ele, percebemos o quanto a questão das rendas era importante para a sobrevivência das equipes. Segundo ele, a equipe são-paulina era atraente por essa questão, mas não estava entre as maiores da cidade.

"No começo, o time era formado meio como uma colcha de retalhos, com jogadores vindos daqui e de lá. E nós não tínhamos grande experiência para contratar jogadores. Além disso, os outros clubes não facilitavam nem um pouco nosso trabalho, - isto porque, naquela época, sendo um clube muito novo, que

\footnotetext{
318 O torneio início dos amadores. A Gazeta Esportiva. 04/05/1936. Pág. 10.

${ }^{319}$ C.R. Tietê - São Paulo X E. C. São Bento. A Gazeta Esportiva. 27/01/1936. Pág. 15.

${ }^{320}$ O E. C. Independete successor do S. Paulo F. C., na APEA. A Gazeta Esportiva. 15/04/1935. Pág. 5.
} 
ainda não havia conquistado seu espaço entre os grandes, a existência do São Paulo era admitida para dar renda, mas não para tirar campeonato."321

O atual São Paulo Futebol Clube não foi o único time formado por simpatizantes e sócios do antigo São Paulo da Floresta. Além do Independente e do C.A. São Paulo, descobrimos que um quarto time foi fundado por ex-militantes do São Paulo da Floresta, com o nome de Estudantes, ${ }^{322}$ que, assim como o Tietê - São Paulo, manteve um time de futebol amador comandado por Friedenreich, o grande ídolo do Paulistano e do São Paulo da Floresta.

Como apontamos, as decisões da diretoria do São Paulo da Floresta de se fundir com o Clube de Regatas Tietê e encerrar as atividades do futebol profissional não foram bem recebidas por muitos dos antigos sócios e simpatizantes. Na verdade, não era bem uma fusão, já que o Tietê se comprometia a pagar a dívida do clube: era a venda do São Paulo da Floresta. ${ }^{323}$

Além disso, no contexto, em que alguns clubes tentaram adotar o profissionalismo e ameaçar o poder exercido pela CBD sobre o futebol brasileiro, o São Paulo da Floresta manteve-se como o último grande time de São Paulo vinculado à APEA contra a CBD. A dívida contraída pela direção do clube para a aquisição da nova sede social e as dificuldades de obtenção de rendas por intermédio do futebol pode ter contribuído para a CBD dificultar a existência do clube. Mas esse não foi o principal motivo que levou ao fechamento do clube.

Segundo A Gazeta Esportiva, a fusão com o Tietê foi decidida como represália à atitude da CBD, que tentava pressionar o clube. ${ }^{324}$ No artigo em A Gazeta, críticas do jornalista indicam que os dirigentes não queriam vinculá-lo à $\mathrm{CBD}$ e foram responsáveis pelo fechamento do São Paulo da Floresta. Nesse período, o próprio periódico fazia críticas abertas à entidade, ao mesmo tempo em que condenava a

\footnotetext{
${ }^{321}$ PIMENTEL, Odair e PENNA, Maysa. Op. Cit. Pág. 40.

${ }^{322}$ PIMENTEL, Odair e PENNA, Maysa. Idem. Pág. 41.

${ }^{323}$ A vontade soberana dos clubes. A Gazeta. 29/01/1935. Pág. 10.

${ }^{324}$ Reagindo contra a vexatória entrega do S. Paulo à CBD por parte de alguns directores, o Conselho administrativo do tricolor resolveu acabar com a secção de futebol, fundindo o clube com o Tietê. $A$ Gazeta Esportiva. 28/01/1935. Pág. 5.
} 
interferência de políticos nos clubes ${ }^{325}$ ou a intervenção estatal no comando da CBD, controlada por Luiz Aranha desde 1934. ${ }^{326}$

Como a decisão foi tomada pelo Conselho Administrativo ${ }^{327}$ do São Paulo da Floresta, sem a participação da maioria dos sócios e simpatizantes, esses tentaram impedir o desaparecimento do time por meio de um recurso na Justiça ${ }^{328}$, iniciativa que não deu certo, razão pela qual, ao longo daquele ano, tomaram a iniciativa de fundarem novas equipes pela cidade. Menzen afirma que

"o São Paulo de hoje surgiu a partir do antigo São Paulo da Floresta, que era formado por jogadores do Paulistano e do antigo Palmeiras, que também desapareceu... Mas esse time foi vendido ao Clube Tietê, por causa de uma série de dívidas que não pode pagar. Foi assim que um grupo de antigos sócios abnegados - e eu diria, um grupo de loucos - inconformados com o desaparecimento do clube, se reuniu e resolveu fundar o São Paulo Futebol Clube." $" 329$

Muitas foram as dificuldades enfrentadas pelo São Paulo Futebol Clube para se consolidar como equipe de ponta no futebol da cidade. Começaram em sua fundação, em dezembro de 1935, e se arrastaram até, pelo menos, o início da década de 1940, quando, nos jogos no Estádio Municipal do Pacaembu, o clube ampliou suas rendas, obteve recursos que lhe permitiram investir em uma grande equipe e comprar sua primeira sede. Até a fusão com o Estudantes, ocorrida em 1938, o São Paulo Futebol Clube enfrentou situações difíceis, semelhantes às enfrentadas por Corinthians e Palestra Itália/Palmeiras, e não despontava entre os grandes times da cidade. Interessante nota, que tais situações foram deliberadamente esquecidas.

\footnotetext{
325 O Palestra infelicitado pela campanha política do Sr. Delmanto. Em sua reunião de ante-hontem, o conselho alvi-verde rejeitou, energicamente, uma proposta para a cessão do Parque Antarctica para um banquete político. A Gazeta. 15/09/1934. Pág. 10. No artigo, o periódico acusava o dirigente palestrino de transformar o Palestra Itália em posto de alistamento do Partido Constitucionalista.

${ }^{326}$ Um presidente esportista da República Velha e um da Nova... A Gazeta. 01/12/1934. Pág. 10. DRUMOND, Maurício. O esporte como política de Estado: Vargas. (In): DEL PRIORE, Mary \& MELO, Victor Andrade de. História do esporte no Brasil. Pág. 234. O autor fala que, desde meados de 1935 o governo Vargas se interessava pelo tema esporte. As referências apontam a interferência de políticos varguistas nas entidades esportistas desde 1934.

${ }^{327}$ Reagindo contra a vexatória entrega do S. Paulo à CBD por parte de alguns directores, o Conselho administrativo do tricolor resolveu acabar com a secção de futebol, fundindo o clube com o Tietê. $A$ Gazeta Esportiva. 28/01/1935. Pág. 5.

${ }^{328}$ PIMENTEL, Odair e PENNA, Maysa. Op. Cit. Pág. 11.

${ }^{329}$ Idem. Pág. 40.
} 
Veremos, mais adiante, que, na trajetória corintiana, quando o aluguel de uma das primeiras sedes não foi pago e o imóvel foi fechado pelo proprietário, o episódio se transformou em relato de heroísmo por parte dos jogadores que invadiram a sede e resgataram os documentos e móveis do clube. No episódio são-paulino similar, o imaginário, consolidado por ideias como elitismo, herança do Paulistano ou do futebol de elite, apagou da memória do clube e de seus torcedores as narrativas relativas às dificuldades enfrentadas em seus inícios.

Frederico Menzen informa que, no início, uma boa renda após uma partida era motivo de grande alegria entre os dirigentes. O clube não possuía campo para treinar, razão pela qual, em seu início, utilizava quadras e campos de outros clubes que existiam na Várzea do Carmo. Segundo o relato,

"No princípio, quando eu era presidente, nós não tínhamos campo para treinar. Então, íamos à Várzea do Carmo, onde havia várias quadras de futebol de meia e outras de clubes de várzea. Chegávamos lá e começávamos a treinar, até que o time dono daquele espaço chegasse e nos expulsasse., 330

Assim, durante alguns meses, a equipe tricolor treinou no campo da Companhia Antarctica Paulista, na Rua da Mooca, cuja concessão pertencia a outro clube remanescente do antigo São Paulo da Floresta, o Estudantes. ${ }^{331}$ Meses depois, encontramos um anúncio em A Gazeta Esportiva que convocava os jogadores para treinar no campo do Olímpica Municipal. ${ }^{332}$ Ao mesmo tempo, a sede social do clube rodava de endereço em endereço pelo centro de São Paulo: encontramos referências às sedes da Praça Carlos Gomes ${ }^{333}$ e da Rua D. José de Barros ${ }^{334}$, além da realização de assembleias gerais na sede da Associação Auxiliadora das Classes Laboriosas, na Rua do Carmo, ${ }^{335}$ e na Associação dos Empregados no Comércio de São Paulo, na Rua Libero Badaró. ${ }^{336}$

\footnotetext{
${ }^{330}$ Idem. Pág. 41.

331 Idem, Ibidem.

332 Pelo São Paulo. A Gazeta Esportiva. 27/06/1938. Pág. 12. Não havia referência ao endereço deste campo.

${ }^{333}$ Idem, Ibidem.

${ }^{334}$ Pelo São Paulo. A Gazeta Esportiva. 12/01/1941. Pág. 3.

335 O S. Paulo F.C. realiza hoje a sua assembleia geral. A Gazeta Esportiva. 28/08/1939. Pág. 6.

${ }^{336}$ Reune-se o Conselho Deliberativo do São Paulo F. C. A Gazeta Esportiva. 09/03/1942. Pág. 4.
} 
O mito fundador são-paulino ajuda a cristalizar a ideia que os fundadores, sócios e simpatizantes do tricolor da década de 1930 faziam parte de um grupo social distinto dos grupos sociais daqueles que fundaram Corinthians e Palestra Itália/Palmeiras duas décadas antes.

O perfil do público são-paulino que acompanhava os jogos naquele contexto também se mostrava equivalente ao público que frequentava os jogos de outras equipes. Nada que lembrasse as arquibancadas do Velódromo Paulista, com famílias, mulheres e crianças. No período estudado, cenas de vandalismo explícito protagonizadas pelos torcedores e dirigentes são-paulinos foram registradas nos jornais. Os sururus ocorriam sistematicamente em jogos de todas as equipes, e os encontramos com certa assiduidade nas partidas do tricolor, sempre com comentários como os que seguem, acerca dos torcedores e dirigentes tricolores:

"Mais um prélio negro a registrar no segundo turno do nosso campeonato. Eis como se pode classificar o cotejo S. Paulo X Espanha, antecipado para anteontem, após as cenas entristecedoras e revoltantes desenroladas aos 18 minutos do período final. Verdadeira miséria moral a depor contra os nossos fóros de gente civilizada e contra os princípios que regem o esporte. Profundamente chocante o que se passou no campo da Rua da Moóca, tendo como protagonistas torcedores fanáticos e irresponsáveis que, julgando-se com direito de fazer justiça pelas próprias mãos, como se vivêssemos num far west, apenas prestaram, mais uma vez, um desserviço ruinoso ao bom nome do association. Cabe ao S. Paulo F.C. apurar a responsabilidade de tais indivíduos e afastá-los como indesejáveis, si porventura pertencem ao seu quadro social, pois que, ficou testemunhado, os autores da estúpida quão covarde agressão ao árbitro da partida se localizaram na arquibancada reservada aos associados tricolors.",337

Naquela ocasião, o juiz foi agredido por expulsar um jogador tricolor que, segundo a mesma fonte, envolveu-se em uma briga com um jogador adversário. Algumas semanas antes, no jogo entre São Paulo e Palestra Itália, as cenas de violência já tinham sido manchete do mesmo periodic. ${ }^{338}$ Em outubro de 1936, após uma partida amistosa entre São Paulo e Juventus, no campo da Rua Javari, a manchete dizia: $O S$. Paulo F.C. fora da lei. Segundo a material,

\footnotetext{
${ }^{337}$ Acontecimentos chocantes arruinaram o prélio São Paulo X Espanha. A Gazeta Esportiva. 20/11/1939. Pág. 5.

${ }^{338}$ Cenas deprimentes no jogo Palestra X São Paulo. A Gazeta Esportiva. 16/10/1939. Pág. 3.
} 
"Os tricolores provocaram feias scenas disciplinares sabbado, no campo do Juventus - um empate de 2 a 2 e um desfecho tumultuado... O S. Paulo e o Juventus combinaram uma partida amistosa para ante-hontem, no campinho da Rua Javari. Mas, de amistoso, o prélio teve talvez apenas a sahida, por que dahi em deante a partida cada vez foi jogada menos correctamente e, por isso mesmo cada vez mais desbancou para a grosseria e a desordem. Um espetáculo de inferior educação esportiva, quando se pensa que, de incidentes em incidentes, acabou-se assistindo a uma scena de... selvageria. Os adeptos do São Paulo F.C., bem o sabemos, andam envenenados com os juízes, porém, não são merecedores de nenhuma sympathia pela maneira como querem reagir contra os mesmos."339

Encontrarmos diversos relatos de episódios de violência nas dependências do Velódromo Paulista e entre associados do Paulistano, mas nada parecido. A seqüência de episódios violentos indicam que o perfil do público que simpatizava ou era sócio do São Paulo era diferente do perfil dos sócios do Paulistano, que estavam nas arquibancadas de futebol nas primeiras décadas do século. Não mais senhoras e senhoritas, cavalheiros e distintos senhores da sociedade, que faziam das arquibancadas sociais um grande evento social, mas um público predominantemente masculino, muitas vezes violento.

O perfil dos dirigentes são-paulinos desde sua fundação era muito parecido com o perfil dos dirigentes dos demais clubes que disputavam o campeonato de futebol: empresários, comerciantes, profissionais liberais e pessoas com algum destaque social. O primeiro presidente são-paulino foi Manoel do Carmo Mecca, comerciante português. ${ }^{340}$ Naquele contexto, Palestra Itália e Corinthians também eram dirigidos por pessoas de algum prestígio social e já tinham sido presididos por industriais e empresários. $^{341}$

Pelos elementos apresentados, transformar o São Paulo Futebol Clube em uma espécie de herdeiro do Paulistano é incorreto, mas teve sua importância econômica para o novo clube angariar os simpatizantes daquela equipe. Funcionou como uma estratégia de marketing. No entanto, é preciso reiterar que esse imaginário elitista, construído para atrair torcedores que simpatizavam com duas equipes que abandonaram o futebol oficial

\footnotetext{
${ }^{339}$ O S. Paulo F.C. fora da lei. A Gazeta Esportiva. 5/10/1936. Pág. 5.

${ }^{340}$ PIMENTEL, Odair e PENNA, Maysa. São Paulo Futebol Clube 1935 - 1980. Op. Cit. Pág. 28. Nesta obra, existe a referência à origem portuguesa de Mecca. São Paulo F. C. 50 anos. Jubileu de ouro. A Gazeta Esportiva. 06/03/1985. Pág. 4. Nesta obra, a referência é a empresa Comercial Mecca.

${ }^{341}$ A eleição do Sr. Manoel D. Corrêa à presidência do Corinthians. A Gazeta Esportiva. 26/01/1942. Pág.
} 2 . 
no final da década de 1920 e início da década de 1930, apaga, para o público em geral, as experiências que aproximam o São Paulo Futebol Clube do Sport Club Corinthians Paulista e da Sociedade Esportiva Palestra Itália/Palmeiras, mas que são fundamentais para sua existência: time de futebol formado ou apoiado por times varzeanos de São Paulo para a atuação no Campeonato Paulista.

\subsection{A década de ouro do Pacaembu e a formação do trio de ferro.}

Em agosto de 1939, o periódico A Gazeta Esportiva publicava a manchete "Formou-se o eixo...Com a derrota do S.P.R., Palestra e Corinthians são os únicos líderes. ${ }^{342}$. Concomitantemente à eclosão da Segunda Guerra Mundial, o periódico anunciava, de maneira sugestiva, a formação do eixo do futebol de São Paulo. Não se tratava de qualquer aliança entre clubes de futebol de origem alemã e italiana ou envolvimento dos dois clubes com as disputas da Segunda Guerra. A matéria informava que Palestra Itália e Corinthians seguiam vivos, como os grandes favoritos a conquistar o título paulista de 1939.

A matéria serve de metáfora para aquilo que ocorria nos bastidores do futebol profissional de São Paulo: a formação das estruturas futebolísticas que se cristalizariam por toda a segunda metade do século XX.

A inauguração do Estádio Municipal do Pacaembu, em abril de 1940, a consolidação da liderança política dos clubes com grande volume de torcedores, como o Sport Club Corinthians Paulista, Sociedade Esportiva Palestra Itália e São Paulo Futebol Clube, e a fundação da Federação Paulista de Futebol em 1941 passaram a ser o eixo do futebol da cidade. Nos clubes, consolidou-se o modelo administrativo por meio do qual determinados empresários, comerciantes ou cidadãos de algum prestígio social assumiam a direção, enquanto os jogadores e torcedores ocupavam um papel subalterno na estrutura dos clubes, mas fundamental para a manutenção do espetáculo. Na história das três grandes equipes da cidade, apenas Roberto Gomes Pedrosa, jogador do São Paulo Futebol Clube, chegou à presidência do clube são-paulino, por alguns meses. E, ainda assim, trata-se de um caso muito particular, visto que se recusava a atuar como jogador profissional, em plena época de implantação do profissionalismo.

\footnotetext{
${ }^{342}$ Formou-se o eixo... A Gazeta Esportiva, 07/08/1939.
} 


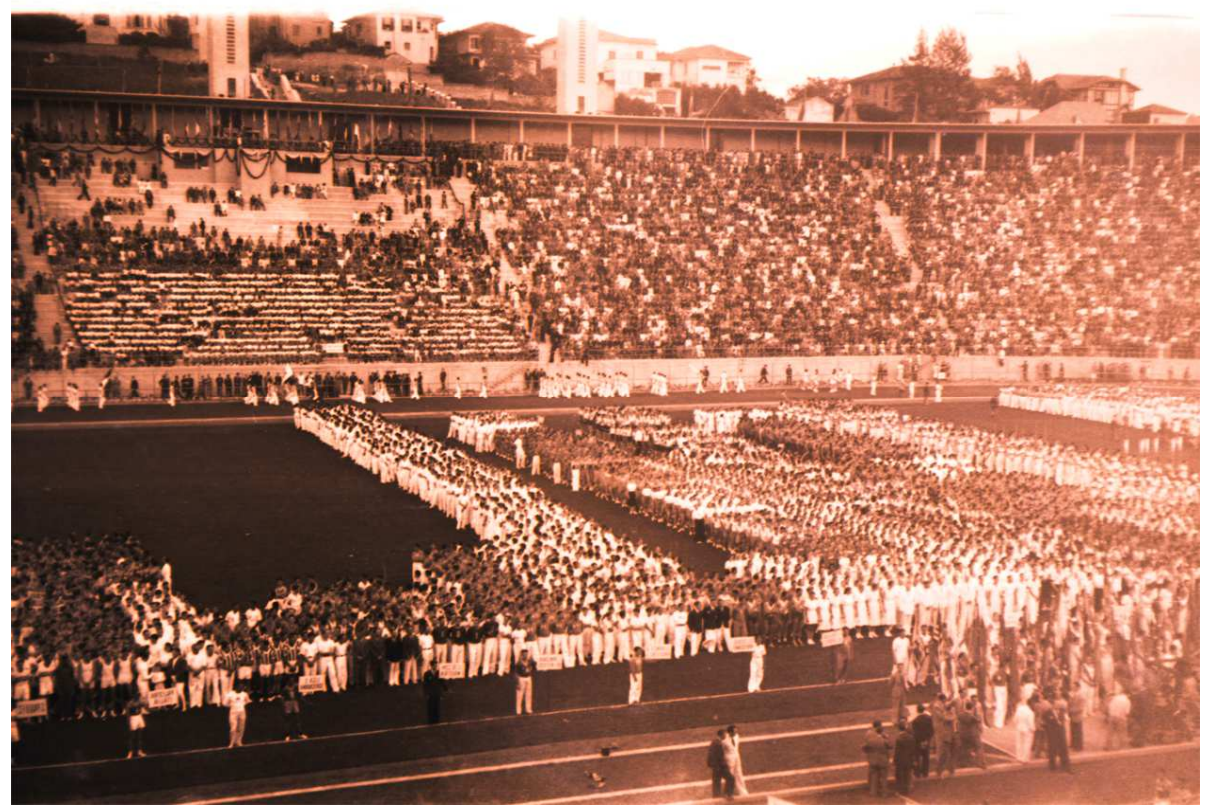

7. Desfile de inauguração do Estádio Municipal de São Paulo. Abril 1940. (Coleção Caio Prado Jr. - IEB USP)

Em 1942, as torcidas organizadas despontaram como desdobramentos das identidades dos clubes, por iniciativa da diretoria são-paulina. ${ }^{343} \mathrm{E}$ a grande contradição das torcidas organizadas ainda hoje, mesmo das que se declaram forças independentes, reside nas relações com as diretorias dos próprios times, pois, embora possuam autonomia institucional e, em alguns casos, tenham se convertido em espaços de exercício e participação coletiva na periferia, ou calda do cometa, para citar Damatta, de um futebol organizado e dirigido autoritariamente, por serem facetas dessas identidades clubísticas, estão intimamente ligadas às demandas e disputas internas dos clubes em todas as esferas. ${ }^{344}$

O papel do Estádio Municipal do Pacaembu, que, nos anos 1960, recebeu o nome de Paulo Machado de Carvalho, foi muito importante nesse processo, porque redimensionou as rendas e o tamanho das assistências, que chegaram à casa dos setenta mil espectadores, ao mesmo tempo em que promovia uma mobilização popular sem

\footnotetext{
${ }^{343}$ TOLEDO, L. H. Lógicas no futebol. Op. Cit. Pág. 251.

344 TOLEDO, L. H. Op. Cit. Págs. 255 e 257.
} 
precedentes e obrigava as autoridades e dirigentes a encontrar formas de conter e regular a conduta torcedora. ${ }^{345}$

A ritualização por meio da normatização foi a maneira que as autoridades e dirigentes encontraram para estabelecer as redes de controle sobre os praticantes. ${ }^{346} \mathrm{~A}$ presença de homens ligados ao governo Vargas nos clubes, como os coronéis Adalberto Mendes, na Sociedade Esportiva Palmeiras, Porfírio da Paz, no São Paulo Futebol Clube e o tenente Oberdan, no Sport Club Corinthians Paulista, foi outra característica em comum entre eles, no início dos anos 1940. Pelo decreto-lei 3.199, de 14 abril de 1941, que criou o Conselho Nacional dos Desportos/CND, todos os clubes foram atrelados de alguma maneira ao Governo Federal.

Essa ritualização/dramatização das identidades coletivas dentro dos estádios, nacionais, locais ou regionais, transformou os estádios em antiestádios de futebol em diversas ocasiões. ${ }^{347}$ Mas lembra Florenzano: os valores da ordem nem sempre coincidiam de modo natural com a ordem cultural do futebol, cuja dinâmica comporta a reavaliação dos significados na prática criativa dos sujeitos históricos. ${ }^{348} \mathrm{O}$ exemplo descrito pelo autor, no período estudado, foi o desfile da pequena delegação são-paulina durante o evento de inauguração do Estádio Municipal, em 1940, quando o público presente a saudou de maneira entusiástica por possuir o nome da cidade e do estado, diante do presidente Getúlio Vargas.

A expressiva ritualidade que o futebol adquiriu naquele contexto só pode ser compreendida por intermédio da rotinização imposta pela ampliação dos campeonatos, a criação de novas competições e pelo ingresso de novas equipes. ${ }^{349}$ E mesmo com todo o esforço apresentado pelos profissionais envolvidos com o futebol em minimizar o espaço para o imponderável no contexto de ressignificação que a sociedade brasileira fez do esporte, dentro do imaginário popular, a demanda da sorte continuou presente,

\footnotetext{
${ }^{345}$ TOLEDO, L. H. Idem. Pág. 252. Segundo o censo de 1940, a população da cidade era de 1.326.261 habitantes (http://sempla.prefeitura.sp.gov.br/historico/tabelas/pop_brasil.php).

${ }^{346}$ FLORENZANO, J. P. A democracia corinthiana. Op.Cit. Pág. 16.

${ }^{347}$ FLORENZANO, J. P. Idem. Pág. 129.

${ }^{348}$ FLORENZANO, J. P. Idem. Pág. 137.

349 TOLEDO, L.H. Lógicas no futebol. Op. Cit. Pág. 33.
} 
como algo que define os resultados das partidas, explicitado pela relação que o termo jogo apresenta. ${ }^{350}$

Pela atuação do CND, surgiu a Federação Paulista de Futebol, ainda em dezembro de 1941. O campeonato de 1942 foi o primeiro organizado pela nova entidade, com o modelo administrativo dos clubes cristalizado como conhecemos hoje e uma surpresa: as sucessivas trocas de nome do Palestra Itália até definir-se como Palmeiras.

A criação do CND foi consequência da atuação do governo Vargas, que tentou normatizar as práticas esportistas no Brasil. Negreiros, ao discutir a intervenção estatal nos meios esportistas sugere que esta só aconteceu após o Estado-Novo ${ }^{351}$.

Mas, pelo menos desde 1934, a CBD era controlada por Luiz Aranha ${ }^{352}$ e recebia generosos subsídios do Governo Federal. ${ }^{353}$ Naquela ocasião, a entidade, que, até então, se recusara a reconhecer o profissionalismo, começou a aderir ao novo regime profissional e por meio de empréstimos aos clubes, promoção de viagens e distribuição dos jogadores selecionados para a Copa de 1934, conseguiu esvaziar as entidades estaduais que no ano anterior tinham se separado dela. ${ }^{354}$ Em setembro de 1934, A Gazeta publica um balancete da entidade e informa que esta só resistia por conta do dinheiro público. ${ }^{355}$ Getúlio Vargas percebia a importância política do futebol e tentou controlá-lo. A delegação brasileira da Copa do Mundo daquele ano foi chefiada pelo jornalista Lourival Fontes, diretor do Departamento de Propaganda e Difusão Cultural/DPDC do Governo Federal. ${ }^{356}$

Apenas com a contratação de diversos jogadores que atuavam profissionalmente pelas ligas estaduais para a Seleção Brasileira que disputou a Copa do Mundo de 1934,

${ }^{350}$ TOLEDO, L.H. Idem. Pág.293. O termo utilizado pelos britânicos para definir a disputa entre duas equipes é match, termo diferente de game. No Brasil, não há diferenças entre match e game, normalmente traduzidos como jogo.

${ }^{351}$ NEGREIROS, Plínio José Labriola de Campos. A nação entra em campo. Futebol nos anos 1930 e 1940. Tese de doutorado, Dep. de História - PUC/SP, 1998. Pág. 52.

${ }^{352}$ Um presidente esportista da república Velha e outro da Nova... A Gazeta. 01/12/1934. Pág. 10. DRUMOND, M. O esporte como política de Estado: Vargas. DEL PRIORI, M \$ MELO, V. História do esporte no Brasil. Pág. 224. O autor informa que, apenas em 1936, Luiz Aranha assumiu a presidência da CBD e que era amigo pessoal de Getúlio Vargas e irmão de Osvaldo Aranha.

${ }^{353}$ O dinheiro do futebol. A Gazeta. 12/09/1934. Pág. 9.

${ }^{354}$ Um presidente esportista da república Velha e outro da Nova... A Gazeta. 01/12/1934. Pág. 10.

${ }^{355}$ O dinheiro do futebol. A Gazeta. 12/09/1934. Pág. 9.

${ }^{356}$ DRUMOND, M. O esporte como política de Estado: Vargas. (In): DEL PRIORI, M. \& MELO, V. História do esporte no Brasil. Op. Cit. Pág. 221. 
a CBD mudou de posição sobre o tema profissionalismo, na medida em que alguns dos melhores jogadores faziam parte de seus quadros, recebiam salários elevados da instituição, mas não podiam participar dos campeonatos porque os grandes clubes atuavam por ligas profissionais independentes.

Assim, conseguimos entender porque Corinthians e Palestra Itália saíram da APEA no final de 1934 e fundaram uma nova liga. E entendemos os motivos que levaram parcela dos dirigentes do São Paulo da Floresta a se recusar a seguir o mesmo caminho. Esse grupo fazia parte das oligarquias paulistas que perderam o poder para Getúlio Vargas alguns anos antes e, naquele momento, perdiam o controle sobre o futebol de São Paulo para os mesmos dirigentes, seus inimigos no plano político nacional. Para eles, era melhor fechar o São Paulo da Floresta que ingressar em Liga controlada pelos representantes de Getúlio Vargas.

A pacificação do futebol paulistano só foi possível com a saída desses grupos entre 1935 e 1937, após o esvaziamento da APEA e o ingresso de suas equipes na Liga Paulista de Futebol, convertida, em 1941, em Federação Paulista de Futebol. A disciplina e a ordem que o Estado-Novo queria instalar sobre todos os aspectos da vida social dos brasileiros, no futebol de São Paulo ocorreu com a inauguração do estádio Municipal, em 1940. Drumond afirma que, apenas em 1937, o amadorismo marrom desapareceria e o profissionalismo se consolidaria entre as principais equipes de futebol do Brasil. ${ }^{357}$

Em outubro de 1941, A Gazeta Esportiva traz um artigo no qual discute aspectos importantes, e o título da matéria é muito sugestivo: Pacaembu, escola da disciplina!

“A inauguração do Estádio Municipal do Pacaembu veio a dar a São Paulo, além de outras, duas grandes vantagens... 1. a" - Boa acomodação aos milhares de afeiçoados que nele assistem a um cotejo qualquer. 2. ${ }^{\mathrm{a}}$ - Impede o contacto direto entre torcedores, jogadores e árbitros, fato esse que não sucede em qualquer outro gramado de nossa capital e de Santos. $" 358$

E a inauguração do novo estádio, que deveria promover a ordem e a disciplina, permitiu que as condições econômicas das principais equipes de São Paulo se alterassem drasticamente. Assim, desde 1940, os clubes de São Paulo reverteram a crise

\footnotetext{
${ }^{357}$ DRUMOND, M. Idem. (In): DEL PRIORI, M. \& MELO, V. Idem. Pág. 229.

${ }^{358}$ Pacaembu, escola da disciplina. A Gazeta Esportiva. 18/10/1941. Pág. 12.
} 
econômica crônica que os assolou por toda a década de 1930. Muitos dos jogadores que partiram entre 1934 e 1937 para o Rio de Janeiro voltaram para São Paulo no início da década de $1940 .{ }^{359}$ As rendas geradas pelo Pacaembu batiam os recordes anteriores de arrecadação a cada partida, em especial as que envolviam Corinthians, Palestra Itália e São Paulo. ${ }^{360}$ Apenas em 1940, foram vendidos 852.452 ingressos no Estádio do Pacaembu. $^{361}$

As grandes estrelas do futebol do Rio de Janeiro passaram a ser cobiçadas pelas equipes de São Paulo, que com as rendas obtidas por meio dos jogos, puderam pagar os valores exigidos pelos times e jogadores do Rio de Janeiro. Consolidou-se um mercado de jogadores de futebol, no qual os jogadores tinham seus passes presos aos clubes com os quais assinavam seus contratos profissionais e esses obtinham lucros nas transações desses passes. ${ }^{362}$ Em contrapartida, algumas das grandes estrelas do espetáculo passaram a receber bons salários para jogar futebol. Notícia na A Gazeta Esportiva nos mostra esse processo:

"O futebol carioca continua sendo um foco de muito ouro e pouca luz. Só se fala nas cifras astronômicas, em verdadeiras fortunas para a aquisição deste ou daquele az famoso. É possível que os chamados grandes clubes da cidade maravilhosa possuam fundos suficientes para esbanjar com jogadores que depois os ajudarão a... enterrar-se no campeonato.",363

O Campeonato Paulista de 1942 teve êxito total, o público compareceu em peso ao Estádio do Pacaembu, as partidas se notabilizaram pela qualidade técnica, Leônidas da Silva despontou no São Paulo com o mesmo futebol que o consagrara no Rio de Janeiro e as três equipes disputaram o título do torneio até as últimas rodadas, quando o Corinthians ficou para trás. Palestra Itália, que trouxera Og Moreira, e o São Paulo de

\footnotetext{
${ }^{359}$ Filhos pródigos à casa tornam... A Gazeta Esportiva. 26/10/1942. Pág. 9.

${ }^{360}$ Palestra - Corinthians - São Paulo. Os clubes que mais renda produzem. A Gazeta Esportiva. 19/07/1941. Pág. 12.

${ }^{361}$ SANDER, ROBERTO. Anos 40. Viagem à década sem copa. Rio de Janeiro, Bom Texto, 2004. Pág. 134.

362 SANDER, ROBERTO. Anos 40. Viagem à década sem copa. Op. Cit. Pág. 49. A lei do passe foi criada como instrumento de defesa dos clubes que revelavam os jogadores. A ideia era impedir que os jogadores trocassem de clube sem que estes recebessem algum tipo de compensação financeira. Segundo o autor, a ideia não era escravizar o jogador. Na prática, os jogadores ficavam reféns dos interesses e caprichos dos clubes que detinham os respectivos passes.

${ }^{363}$ Cifras astronômicas. A Gazeta Esportiva. 02/03/1942. Pág. 2.
} 
Leônidas da Silva decidiram o título na partida de 20 de setembro, quando o Palestra Itália foi campeão.

Fez parte desse processo de ritualização a promoção das partidas nos grandes jornais da cidade como A Gazeta e O Estado de S. Paulo. A atuação dos cronistas e colunistas ajudou a construir as expectativas dos torcedores ao longo das semanas que antecediam os grandes encontros. ${ }^{364}$ Desde o final dos anos 1920, a partida entre Corinthians e Palestra Itália era denominada pelo mesmo cronista como o derby da cidade. $^{365}$

${ }^{364}$ Um majestoso não é espetáculo de todos os dias. A Gazeta. 02/07/1942. Pág. 6.

${ }^{365}$ A expressão derby para o cotejo Palestra X Corinthians. A Gazeta. 02/04/1942. Pág. 8. Em referência à mais antiga competição do turfe mundial, considerada a jornada máxima deste esporte na Inglaterra, organizada em sua origem por Lorde Derby. 


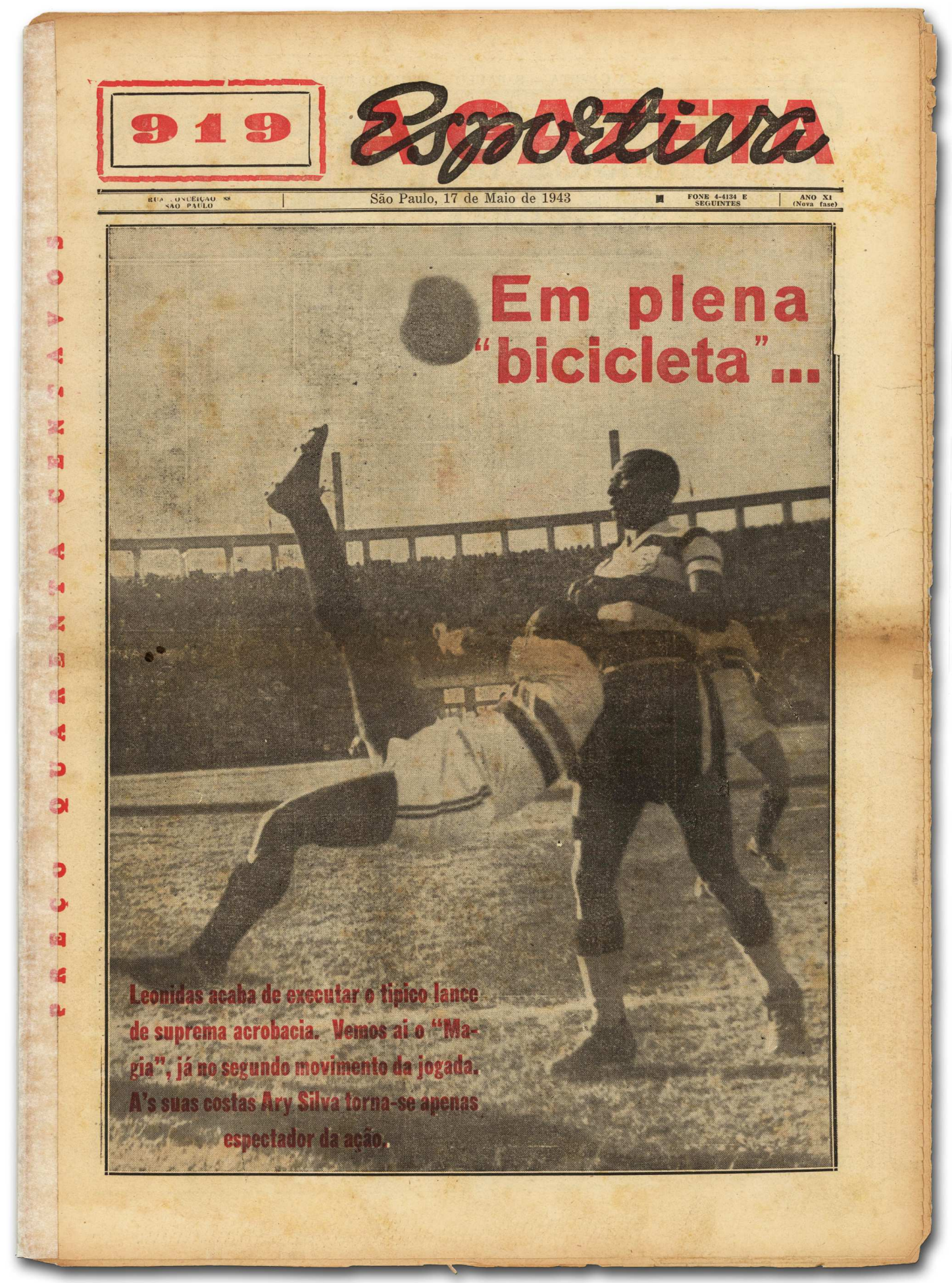


Aquela geração do início dos anos 1940 era formada por jogadores excepcionais $^{366}$ e Leônidas da Silva se destacava como a grande estrela do espetáculo por conta de seus recursos técnicos. Ainda em 1942, a execução de uma bicicleta no Pacaembu renderia uma belíssima manchete no periódico A Gazeta Esportiva: O maior espetáculo da tarde: o goal bicicleta de Leônidas.

"O espetáculo do goal malabarístico de Leônidas, com o seu lance típico, conhecido por bicicleta, foi imponente, com a circunstância de ter surgido tão repentino a ponto de Leônidas não tomar qualquer atitude ao executar a "bicicleta" e muito menos esboçar o alvo da meta. Foi um relâmpago... Depois de quatro anos, deu-se a coincidência da repetição do lance e, francamente, consagrou Leônidas no Campeonato Paulista."367

A contratação de Leônidas pelo São Paulo Futebol Clube mexeu com a rotina da cidade. Cerca de dez mil pessoas foram acompanhar sua chegada na Estação do Norte, no bairro do Brás, quando o jogador foi aclamado pela multidão. ${ }^{368}$ Tratava-se da maior transação do futebol brasileiro, pois a equipe tricolor pagou 200 contos para que o Flamengo o liberasse. ${ }^{369}$ Sua estréia ocorreu em uma partida contra o Corinthians, assistida por multidão de mais de setenta mil torcedores, recorde de público no Estádio do Pacaembu que perdura ainda hoje. ${ }^{370}$ A renda líquida obtida pelas equipes foi de 151:857\$500, quase o valor que Leônidas custou aos cofres são-paulinos. Pelas cifras envolvidas nessa partida, Mazzoni a define como o choque majestoso.

As rivalidades entre os torcedores que geravam confusões nos campos dos anos 1930 mantiveram-se ou mesmo se ampliaram naquele contexto. O clímax foi alcançado nas semanas que antecederam a partida entre São Paulo e Palestra Itália que decidiria o título daquele ano e que estava marcada para o dia 20 de setembro. Trocas de insultos entre as diretorias, boataria envolvendo uma possível nacionalização do Palestra Itália e uma briga no Parque Antarctica, por ocasião de uma partida de juniors, apimentaram a partida, que, no entanto, não teve um grande desfecho, em decorrência do abandono

\footnotetext{
${ }^{366}$ SANDER, R. Op. Cit. Pág. 42.

${ }^{367}$ O maior espetáculo da tarde: o "goal bicicleta” de Leônidas. A Gazeta Esportiva. 15/06/1942. Pág. 6.

${ }^{368}$ SANDER, R. Op. Cit. Pág. 75.

${ }^{369}$ SANDER, R. Op. Cit. Pág. 75.

${ }^{370}$ O movimento financeiro do espetáculo majestoso. A Gazeta Esportiva. 25/05/1942. Pág. 8.
} 
tricolor. Essa partida foi apelidada por Mazzoni de choque-rei, em razão de ser a partida decisiva daquele que era o maior Campeonato Paulista de todos os tempos.

Ao término daquele campeonato, o trio de ferro se formara e, no Estado de São Paulo, apenas o time do Santos F. C., a partir do momento em que Pelé e Cia. encantaram o mundo com o futebol refinado, entre a segunda metade da década de 1950 e a década de 1960, conseguiu se equiparar às três equipes. Das equipes do interior de São Paulo, apenas Internacional de Limeira, em 1986, e Bragantino, em 1990, sagraram-se campeãs do Campeonato Paulista no século XX. A Portuguesa apenas dividiu um título com o Santos, na década de 1970. 


\section{Sociedade Esportiva Palmeiras. O time unificador da colônia italiana em São Paulo?}

\subsection{As relações do Palestra Itália com outras equipes da comunidade italiana de São Paulo.}

"Formata su basi ben modeste, mas piena di speranza per il futuro, la Palestra fu creata da un gruppo di giovani volenterosi i quali vi dedicarono anima e corpo, e findai primi tempi della fondazione dettero alla società un programma vasto da svolgere, riunendo in seno ad essa tutti i migliori calcisti italiani sparsi nei clubs nacionali., ${ }^{371}$

"Os italianos da América do Sul aprendem e falam mais facilmente o espanhol e o português do que o italiano. Por quê? Porque os italianos que para lá emigram falam seus dialetos. Por exemplo: um piemontês, jovem ou adulto, que chega ao Brasil tem quase o mesmo trabalho para aprender o italiano ou o português, e então procura aprender o português, antes do que o italiano." 372

"A minha missão terminou (...) Tinha que escrever do que foi, do passado, alimentar a saudade, nada mais, mesmo me sentindo e vivendo o Palmeiras de hoje, do qual, outros mais brilhantes e mais competentes do que eu, dirão os faustos acontecimentos, a marcha progressiva, a glória maravilhosa, a afirmação esplendorosa, que, brasileiramente ostenta (...) Não lembrei a nomes. Muito a lembrar, pois se há, no momento, muitos grandes palmeirenses, muitos grandes palestrinos deram, ontem, o que de melhor tinham na mocidade, agora, infelizmente, no ocaso. Lembrei só de um: de Luigi Cervo, o maior, o que na sua pobreza foi rico: ninguém lhe tolherá a riqueza de ter dado a nós o Palestra Itália, um monumento de raça latina, cujo sol irradia, hoje, em todo o mundo onde o futebol é o Esporte-Rei de multidões de todas as vibrações." 373

As partidas entre Sport Club Corinthians Paulista e Sociedade Esportiva Palestra Itália chamaram a atenção de Antonio Alcântara Machado que publica em Brás, Bexiga

\footnotetext{
${ }^{371}$ Palestra Itália. Fanfulla. 26/08/1916. Pág. 5.

${ }^{372}$ COUTO, Ronaldo Costa. Op. Cit. Págs. 301 e 302. CENNI, Franco. Os italianos no Brasil. Pág. 323.

373 RAGNETTI, Vicenzo. No tempo de Palestra é Palestra. Jubileu de ouro. Sociedade Esportiva Palmeiras (1914-1964). S/P.
} 
e Barra Funda, editado em 1927, o conto intitulado Corinthians (2) vs. Palestra(1). ${ }^{374}$

Nele, podemos visualizar algumas características marcantes dos campos de futebol na cidade de São Paulo da década de 1920: o espaço improvisado a que hoje chamamos de arquibancada, que chegava a receber alguns automóveis e caminhões no meio de árvores da geral, ${ }^{375}$ que derrubavam gente ${ }^{376}$ público estimado em cerca de vinte mil pessoas; a proximidade entre jogadores e torcedores, separados por pequena grade ou alambrado, do contrário o jogador Filipino não mergulharia na multidão; a confusão entre torcedores e a atuação enérgica da polícia. ${ }^{377}$

${ }^{374}$ MACHADO, António de Alcântara. Novelas Paulistanas. Brás, Bexiga e Barra Funda, Laranja da China, Mana Maria e Contos Avulsos. Pág. 30. CARNELLI, Mário. Carcamanos \& Comendadores. Pág. 166. Ao analisar o conto de maneira breve, o autor propõe a distinção entre Corinthians e Palestra Itália da seguinte maneira: "O Palestra é o clube de futebol italiano por excelência, ao passo que o Corinthians é mais o dos ítalo-paulistas." Não é objetivo nosso discutir os aspectos literários e ideológicos da obra de Alcântara Machado e, para maiores informações, ver Carnelli, que apresenta vasta bibliografia.

${ }^{375}$ MACHADO, António de Alcântara. Op. Cit. Pág. 33. Quando o Velódromo Paulista foi reformado e seu uso para o ciclismo abandonado, as pistas viraram espécies de arquibancadas, lugares improvisados de onde se assistia às partidas em pé. Esses locais receberam o apelido de Arquibancadas Gerais e eram destinados ao público de menor poder aquisitivo. No conto, Alcântara Machado estabelece esta relação entre o galho da árvore e as gerais por tratar-se de local improvisado e desconfortável para se ver um jogo de futebol.

376 MACHADO, António de Alcântara. Op. Cit. Págs. 32 e 33. Pelos anúncios nos periódicos, observamos que a presença de caminhões nos campos era constante. Em dia de jogos concorridos, os periódicos anunciavam que o ingresso de caminhões nos campos não seria autorizado.

377 TOLEDO, L.H. Op. Cit. Pág. 248. O autor apresenta matéria publicada n’A Gazeta Esportiva em 29/06/1931, acerca de uma partida entre Corinthians e São Paulo da Floresta que teve "um epílogo de quase todos os jogos nestes últimos tempos: a assistência exaltadíssima à espera da saída do juiz para a indispensável agressão (...) o juiz deixou o campo debaixo de uma chuva de pedras e pau (...)”. Desde então, a violência das torcidas é uma preocupação das autoridades envolvidas com o futebol. 


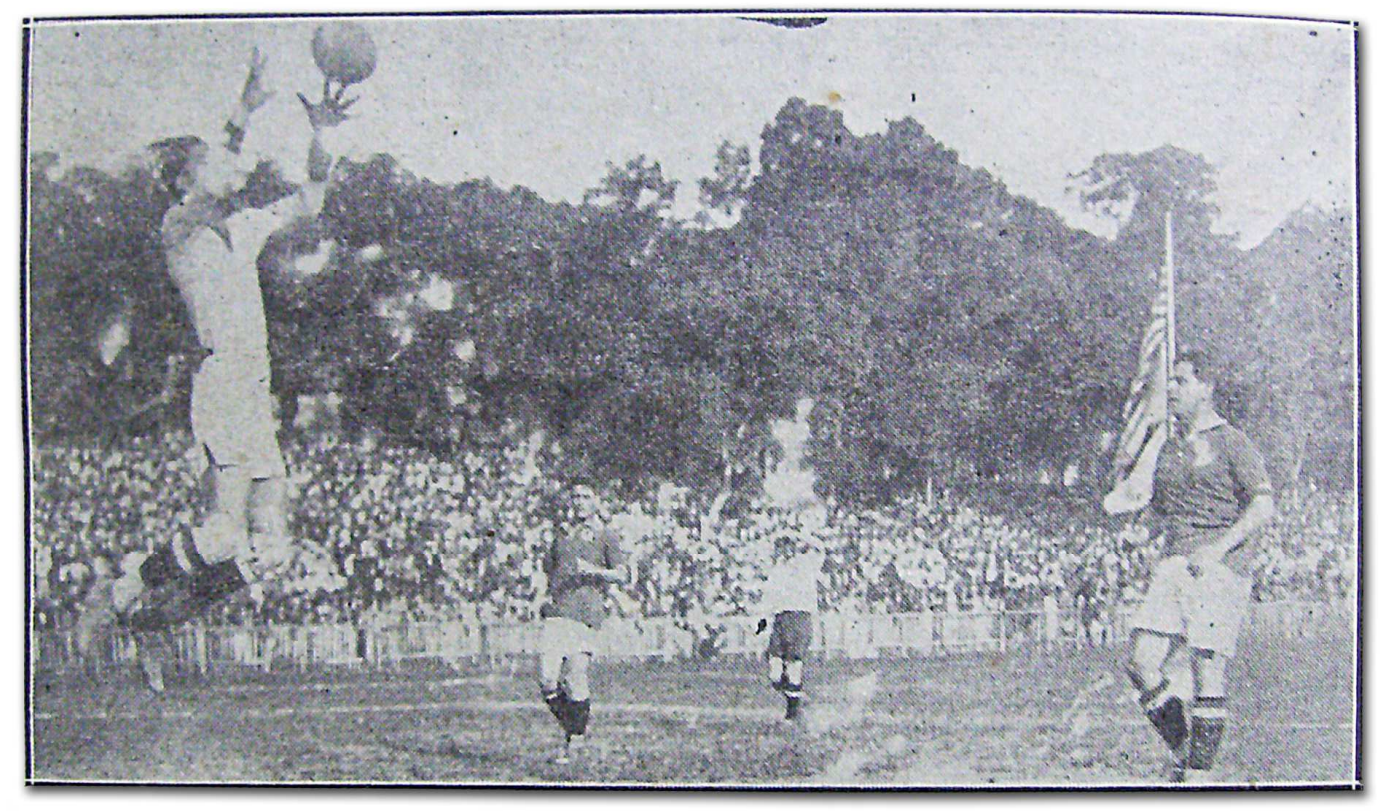

8. Partida disputada no Parque Antártica na década de 1920. Ao fundo o pequeno cercado que separava o gramado da torcida.

Outros aspectos que chamam a atenção se relacionam com questões identitárias e são analisadas neste capítulo: a paixão que envolve a personagem principal pelo Palestra Itália e a proximidade entre corintianos e palestrinos, que, na crônica, frequentavam a mesma sociedade dançante no bairro, moravam no mesmo bairro/rua e formavam entre seus simpatizantes um público de perfil muito semelhante. Podemos pensar na construção de uma competição identitária cismogênica como a que o antropólogo Marshall Sahlins sugere ao interpretar as rivalidades entre Atenas e Esparta, na Antiguidade Clássica. ${ }^{378}$

No decorrer do século XX, as disputas entre Corinthians e Palmeiras - Sociedade Esportiva Palestra Itália até 1942 se transformaram nos eventos futebolísticos mais concorridos da cidade, salvo em alguns períodos históricos muito específicos, como nos tempos do Santos de Pelé ou da década de 1940, quando as rivalidades entre palmeirenses e são-paulinos foram apimentadas pelos conflitos de 1942 e pela ascensão são-paulina capitaneada por Leônidas da Silva.

Podemos afirmar que as duas equipes, Corinthians e Palmeiras, construíram a maior rivalidade entre seus simpatizantes - a despeito de corintianos e palmeirenses

\footnotetext{
${ }^{378}$ SAHLINS, Marshall. História e Cultura. Apologias a Tucídides. Rio de Janeiro, Zahar, 2006. Pág. 83.
} 
rivalizarem com santistas e são-paulinos, também. As narrativas e memórias das duas equipes apontam como razões para tal rivalidade motivações nacionais: a origem italiana do Palmeiras e a espanhola do Corinthians; de classe: a origem classe média dos palmeirenses e a origem humilde dos corintianos; raciais: o Corinthians foi o primeiro a se abrir aos negros e o Palmeiras, o último; e as disputas no campo de jogo: sempre acirradas pelos motivos acima expostos.

No entanto, a análise da documentação encontrada até agora deixa claro que na trajetória de Corinthians e Palmeiras, a construção das memórias de cada equipe passou por uma situação semelhante à descrita pelo antropólogo norte-americano Sahlins sobre a trajetória de atenienses e espartanos: trata-se de uma competição cismogênica, na qual os relatos, memórias e identidades de cada clube foram construídos em uma relação de ponto e contraponto entre duas equipes, pela qual, a história e/ou a trajetória de um clube se definiu na negação da história/trajetória do outro clube. E, o mais interessante, os elementos que os aproximam foram deliberadamente apagados da memória oficial dos clubes no decorrer do século XX.

Assim, os jogadores que atuaram simultaneamente nas duas equipes quando o Palestra Itália foi fundado são mencionados nas memórias oficiais sem qualquer referência às duplas atuações, assim como pouco se fala na origem italiana do Sport Club Corinthians Paulista e nas dificuldades econômicas encontradas pela Sociedade Esportiva Palestra Itália em seu início. Os nomes de tais jogadores não são citados, por exemplo, na placa expositiva palestrina no Museu do Futebol em São Paulo e apenas um deles, Amílcar Barbuy, é citado na corintiana como um dos principais ídolos alvinegros, sem qualquer referência ao fato de ter sido um dos primeiros ídolos palestrinos. E não há referência a esses jogadores no Álbum Celebrativo do Jubileu de Ouro da Sociedade Esportiva Palmeiras. O álbum Corinthians Campeão dos Centenários $^{379}$ informa secamente que, ao término de 1925, o jogador Amílcar Barbuy migrou para o Palestra Itália.

A construção da identidade palestrina/palmeirense percorre uma trajetória relacionada à comunidade italiana e seus descendentes até meados da década de 1940, quando, após a mudança de nome, o clube abriu-se para outros grupos da sociedade e aceitou jogadores de outros grupos étnicos e nacionais, modificando o perfil de seus

\footnotetext{
${ }^{379}$ Corinthians. Campeão dos centenários. Pág. 85.
} 
associados/simpatizantes. É importante chamar a atenção para o fato de não ter sido a única equipe de origem italiana na cidade, mas justamente a que maior êxito teve em construir representação de italianidade nas arenas esportivas.

O time corintiano permaneceu fechado, sem aceitar a presença de negros entre seus jogadores por toda a primeira década de sua existência, entre jovens brancos oriundos de comunidades de imigrantes, em especial italianos e espanhóis, como podemos perceber do relato deixado por Mazzoni: "Em 1914, o Corinthians não havia incluído em seu quadro o extraordinário centro-médio David, por ser um 'colored.'” ${ }^{380}$ E, em 1914, quando da visita da equipe italiana do Torino, Vittorio Pozzo, cronista esportivo e treinador dessa equipe escreve dados que são pistas interessantes sobre o que era o time do Corinthians naquele contexto:

"Una squadra formidabile in tutte lê linee é il Corinthians, il campione Paulista, che giuoca com uma foga tremenda. Il Corinthians há nelle proprie file italiani o figli di italiani e tutti sone individualmente di classe superiore all media dei giuocatori che giuocano in Itália." 381

De certa maneira, a trajetória palestrina se aproxima da trajetória desta outra equipe, também criada por elementos da comunidade italiana em São Paulo: o Sport Club Corinthians Paulista. Até a fundação do Palestra Itália, a comunidade italiana não se organizava por meio de um clube de futebol ou se identificava com apenas uma equipe. Os italianos espalhavam-se por diversas agremiações existentes nos bairros. Mesmo depois da fundação, diversas equipes de origem italiana ou fundadas por descendentes continuaram a existir ou foram fundadas, ${ }^{382}$ situação que desmente o suposto caráter unificador que o Palestra Itália teria exercido entre os italianos de São Paulo. ${ }^{383}$ E o Corinthians era uma dessas agremiações.

\footnotetext{
${ }^{380}$ MAZZONI, T. Op. Cit. Pág. 119.

381 FIGUEIREDO, A. Op. Cit. Pág. 89. A informação de que Pozzo era também cronista consta do trabalho de RIBEIRO, R. O caminho da bola. Op. Cit. Pág. 122.

${ }^{382}$ CARELLI, M. Op. Cit. Pág. 53. Um dos traços mais marcantes dos italianos de São Paulo era sua propensão em criar associações de todos os tipos, musicais, caritativas, esportivas ou políticas, refletindo as diversas correntes ideológicas da colônia, que compreende monarquistas, republicanos garibaldinos, socialistas, anarquistas, positivistas e católicos.

${ }^{383}$ Cf. ARAÚJO, José Renato de Campos. Imigração e futebol. O caso Palestra Itália, que defende esta tese. CARELLI, Mário. Carcamanos \& Comendadores. Pág. 34. CENNI, Franco. Os italianos no Brasil. Pág. 231. Os italianos se fixaram em determinados bairros, de acordo com a origem peninsular, desde o século XIX: napolitanos no Brás, calabreses no Bexiga, e os vênetos, no Bom Retiro. SANTOS, Viviane
} 
Em julho de 1914, o Fanfulla anunciou a organização de uma festa esportiva destinada a mobilizar a comunidade italiana em São Paulo em benefício do Hospital Italiano, depois denominado Humberto Primo, e que tinha por principal atrativo a partida disputada entre o Germânia e o Corinthians, no Parque Antarctica. Mesmo após a fundação do Palestra Itália, o time do Corinthians ainda era convidado para representar a comunidade italiana em partidas de futebol, como a partida disputada em 6 de dezembro de 1914 contra o Sport Club Luzitano e que foi organizada em homenagem às comunidades portuguesas e italianas. ${ }^{384}$

Naquela ocasião, as disputas entre a LPF e a APEA chegavam ao apogeu e teriam um efeito não esperado pelos dirigentes das duas entidades: o estímulo do futebol dentro das comunidades de italianos e seus descendentes em decorrência das visitas de equipes italianas, uma das quais nomeada de Representação Oficial Italiana.

Em oito de julho de 1914, o Correio Paulistano informa que por um convite da Liga Paulista de Futebol, a equipe de futebol do Torino, clube italiano que se destacava na época, visitaria a cidade de São Paulo no mês de agosto. E aproveitava para convocar os jogadores que deveriam tomar parte da Seleção da LPF e participar de cinco treinos. O time A seria composto pelo goleiro João (Hydecroft, de Jundiaí); os zagueiros Jaeger e Eskildsen (ambos do Germânia); os meias Aquino e Bucker (do Internacional); os atacantes Friese (do Germânia), Enrico (do Internacional), Peres, Aparício e Neco (do Corinthians). O time B contava com o goleiro Sebastião (do Corinthians); os zagueiros Casimiro e Fulvio (do Corinthians); os meias Gerkardt, Bianchi (ou Bianco, do Corinthians) e Zecca; Fiaschi (do Corinthians), Mariano, Manne, C. Elyseos e Baugartner $^{385}$. Em nota publicada no dia 12 de julho, o mesmo periódico informava que a equipe do Torino deveria chegar à cidade em cinco de agosto. ${ }^{386}$

Uma semana depois, o mesmo jornal anuncia a visita da Representação Oficial Italiana também para o mês de agosto de 1914, para a disputa de uma série de amistosos organizados pela APEA. No decorrer da nota, tenta justificar o uso do termo

Teresinha dos. Rivoluzionari in San Paolo. A comunidade italiana e a Polícia Política (1924 - 1945). Pág. 13. A autora informa que existiram diversas correntes políticas dentro da comunidade ítalo-paulista e todas receberam maior ou menor atenção da polícia brasileira na primeira metade do século XX.

${ }^{384}$ Al Parco Antarctica. Fanfulla. 3/12/1914. Pág. 6. I matches di foot-ball che si diputeranno domani al Parco Antarctica. Fanfulla. 5/12/1914. Pág. 7.

${ }^{385}$ Chrônica Sportiva. Correio Paulistano. 8 de julho de 1914. Pág. 3. O jornal não informa a origem dos jogadores do time $\mathrm{B}$, apenas daqueles que atuaram pelo Corinthians.

${ }^{386}$ Chrônica Sportiva. Correio Paulistano. 12 de julho de 1914. Pág. 3. 
Representação Oficial Italiana para um time que, sabidamente, não era a Seleção Italiana. ${ }^{387} \mathrm{O}$ Fanfulla, no dia 20 de julho informava que:

"Mentre la Lega Paulista di foot-ball attivamente trattava e concludeva col Torino FBC per uma serie di matches da ginocarsi a San Paolo com le proprie societá affliate, l'Associasão (sic) Paulista de Sports Athleticos faceva altrettanto col Rag. Giuseppe Milano - capitano della Pro-Vercelli - perottenere la venuta della Squadra Nazionale."

Com o conhecimento prévio da programação montada pela LPF, a APEA organizou um evento capaz de esvaziar o evento da liga rival e gerar grandes somas. As partidas disputadas pelo Pro-Vercelli/Seleção Italiana foram realizadas a toque de caixa e, quando o Torino chegou para seus amistosos em agosto, a cidade encontrava-se tomada de euforia pela presença da Seleção Italiana que, àquela altura, já disputara duas partidas. ${ }^{388}$ Por uma farsa que gozou do apoio de parte da mídia e do Consulado Italiano, em julho, a APEA informava aos cidadãos paulistanos que a Seleção Italiana de Futebol atuaria em São Paulo sob seu patrocínio, em agosto daquele ano, no mesmo instante em que o Torino visitava a cidade. Apenas em dois de agosto de 1914, com uma foto estampada na capa, o mesmo periódico informa que a Representação Oficial Italiana era na verdade o time do Pro-Vercelli. ${ }^{389}$

O entusiasmo que a visita da Representação Oficial Italiana causou na comunidade italiana de São Paulo foi enorme. Algumas partidas disputadas no Velódromo Paulista receberem enorme assistência. Segundo a estimativa feita pelo jornalista do Correio Paulistano, a partida de estreia teve um público próximo a dez mil pessoas. ${ }^{390}$ Se o intuito dos organizadores era esvaziar a visita do Torino organizada pela LPF, a presença do Pro-Vercelli pelo menos conseguiu minimizar o apelo midiático e popular daquelas partidas.

\footnotetext{
${ }^{387}$ Chrônica Sportiva. Correio Paulistano. 19 de julho de 1914. Pág. 2. O entusiasmo produziu a sensação de que as partidas disputadas entre o Pró-Vercelli e as equipes da APEA seriam verdadeiras disputas entre a Seleção Italiana e a Seleção Brasileira, com direito à taça chamada Itália-Brasil.

${ }^{388}$ MAZZONI, T. História do futebol no Brasil. Pág. 95.

${ }^{389}$ Chrônica Sportiva. Correio Paulistano. 2 de agosto de 1914. Capa.

${ }^{390}$ Chrônica Sportiva. Correio Paulistano. 3 de agosto de 1914.
} 
A leitura das fontes nos permitiu verificar que a LPF teve que mudar seus planos por conta da visita do Pro-Vercelli. ${ }^{391}$ Primeiramente, com apoio da Federação Italiana de Futebol (Calccio em italiano) - FIC e da FIFA, conseguiu a proibição do uso do termo Representação Oficial Italiana nas partidas e divulgou a proibição nos jornais, razão pela qual o Correio Paulistano se esforça para justificar a utilização do termo Representação Oficial Italiana, no dia 19 de julho. Segundo a LPF, o Pro-Vercelli estava proibido pela FIC de usar os termos Squadra Italiana, Representação Oficial ou Seleção, considerados abusivos, fantásticos e especulativos. E teve que reorganizar as apresentações. Em vez do selecionado convocado em julho, cada equipe afiliada à LPF disputaria uma partida contra o Torino. Apenas o Germânia desistiu de sua partida, por conta da deflagração da Primeira Guerra Mundial, razão pela qual, a LPF improvisou um time formado por jogadores estrangeiros para atuar na segunda partida do Torino em São Paulo. A presença do público no Parque Antarctica foi bem menor do que o esperado pela LPF e em relação ao que acorreu ao Velódromo Paulista, exceto no jogo disputado entre Corinthians e Torino. Esse jogo teve público estimado em quatro mil pessoas. $^{392}$

A APEA, para driblar a proibição imposta pelas entidades oficiais, utilizou-se da ajuda da Liga Carioca (Liga Metropolitana de Sports Terrestres). Como a FIFA não reconhecia a APEA como representante do futebol em São Paulo, proibia qualquer iniciativa dela para realizar eventos esportivos de caráter internacional. Assim, esta última buscou apoio da Liga Metropolitana para organizar a excursão, que, oficialmente, convidou o time do Pró-Vercelli para visitar o Brasil. E a autorização para que o Pro-Vercelli usasse uniformes azuis semelhantes ao utilizado pela Seleção Italiana nas partidas disputadas no Velódromo partiu do Consulado Italiano em São Paulo. ${ }^{393}$

A fundação do Palestra Itália está diretamente relacionada às visitas dos times italianos em agosto de 1914. Aliás, a leitura acurada dos jornais daquela época permite

\footnotetext{
${ }^{391}$ La venuta a San Paolo dei foot-ballers italiani. Cio que afferma la Liga Paulista a propósito della ProVercelli. Fanfulla. 22/07/1914. La Pro-Vercelli ufficialmente diffidata di venire a San Paolo. Fanfulla. 19/07/1914. Pág. 5.

${ }^{392}$ Il Torino FBC baite la squadra campione della Liga per 3 goals a zero. Fanfulla. 16/08/1914. Pág. 5. Alguns jogos no Velódromo também não tiveram grande público, como o disputado entre o Pro-Vercelli e o combinado formado por São Bento e Ypiranga, segundo o mesmo jornal. Al Velódromo. Fanfulla, 10/08/1914. Pág. 5.

393 Squadra calcisca italiana. Ancora una prova ch'essa é stata autorizzata a venire in Brasile. Fanfulla. 06/08/1914. Pág.4.
} 
verificar que o Palestra Itália não foi o único time fundado por italianos ou seus descendentes por conta da visita do Pro-Vercelli/Representação Oficial Italiana e do Torino. Os times que surgiram, como o Touring F. C., Smart F.C., Societá Calcistica Florentia Amicci dello Sport, o Paraíso F. C., Ítalo F.B.C. ou o Itália F.C., tinham entre seus fundadores, nomes e sobrenomes italianos. ${ }^{394}$ Além do entusiasmo junto à comunidade italiana em São Paulo, as visitas dos times, ao se mesclarem com os sentimentos nacionalistas despertados pela deflagração da Primeira Guerra Mundial, instigaram episódios de violência que envolveram brasileiros e italianos. ${ }^{395}$

Em 27 de agosto de 1914, o Fanfulla informa, em nome da presidência do Palestra Itália:

"Há avuto luogo ieri será la seconda riunione dei soci della Palestra Itália la cui sede è in Rua Marechal Deodoro, $\mathrm{n}^{\circ} 2$.

Numerosi fureno gli intervenuti: la direcione è stata casi composta: Presidente, Ezequiel Simoni - Vice-Presidente Luigi E. Marzo - Secretário, Luigi Cervo - ViceSecretário Antonio Auliciano - Cassieri, Francesco de Vivo - Primo Maestro di Sala, Álvaro F. Silva - Secondo Maestro di Sala, Francesco Morelli - Inspetor di Sala, Adolfo Izzo, Vincenzo Cilento - Revisori di Conti, Oreste Giangrande, Armando Rebucci, Guido Giannetti - Diretore Sportivo, Vicenzo Ragognetti.

Come abeamo anauziato, la Palestra Itália comprenderà uma sezione filodramatica - danzante ed uma sezione sportiva per la formazione di uma squadra italiana di foot-ball.

Si sono giá iseritti diversi giuocatore del calccio appartenenti à societa affigliate all'Associazione Paulista.",396

E, em 1914, havia a intenção dos dirigentes palestrinos de se filiar a APEA, ${ }^{397}$ algo que atestava que as disputas entre APEA e LPF pendiam em favor da primeira. O clube possuía, naquela ocasião, um campo provisório na Vila Mariana, na Rua Major Maragliano, n. ${ }^{\circ}$ 54, motivo que tornou possível o seu ingresso na APEA, em fevereiro de $1916 .{ }^{398}$ Durante todo o ano de 1914 , as atividades que mais êxito tiveram foram os

\footnotetext{
394 Chrônica Sportiva. Correio Paulistano. 12/09/1914. Pág. 3. Fanfulla. 32/08/1914. Pág. 7. Fanfulla. 26/08/1914. Pág. 5. Por todo o semestre, novas equipes surgiram e foram noticiadas pelo periódico.

${ }^{395}$ Il nazionalismo nel foot-ball. Fanfulla. 14/08/1914. Pág. 4.

${ }^{396}$ Palestra Itália. Fanfulla. 27/08/1914. Pág. 4.

${ }^{397}$ La Palestra Itália se affiglierà in questi giorni all'Associazione Paulista di Sports Attetici. Fanfulla. 19/10/1914. Pág. 4.

${ }^{398}$ Correio Paulistano. 23/02/1916. Pág. 2. O ingresso do Palestra Itália foi decidido na reunião em que a equipe do The Wanderers foi eliminada, por não possuir campo próprio e não ter apresentado outros documentos exigidos pela entidade.
} 
bailes organizados no salão alugado na Rua Marechal Deodoro, aos domingos à tarde. Além de frequentar a coluna de esportes do Fanfulla, o nome Palestra Itália era recorrente na coluna Circoli e Societá. E, a despeito de todo o esforço do periódico para divulgar as atividades da agremiação, ainda em 1916, ao ingressar na APEA, o Palestra Itália era uma desconhecida Sociedade Esportiva fora dos meios italianos. ${ }^{399}$

Um dos mitos mais difundidos nas discussões futebolísticas da cidade afirma que o Palestra Itália surgiu de uma dissidência corintiana. Pelo levantamento realizado até agora, não foi bem isso. De fato, em 1915, quando o Palestra Itália começou a disputar suas primeiras partidas contra equipes diversas, alguns jogadores do time do Corinthians atuaram pelas duas equips. ${ }^{400} \mathrm{Na}$ primeira partida disputada pelo Palestra Itália contra o time do Savoia - o time também foi obrigado a adotar novo nome em 1942 e, atualmente, se chama Votorantim, que pertencia, então, a um subdistrito da cidade de Sorocaba -, quase metade da equipe era formada por jogadores corintianos.

Naquela ocasião, segundo o artigo $18 .^{\circ}$ dos estatutos do Sport Club Corinthians Paulista, os jogadores corintianos só poderiam atuar por outras equipes com o consentimento da direção do clube. ${ }^{401}$ Portanto, os jogadores corintianos que atuaram, simultaneamente, pelas duas equipes em 1915, provavelmente, o fizeram com o consentimento da diretoria corintiana. Assim, Amílcar Barbuy, Américo Fiaschi, Bianco Spartaco Gambini, Fulvio Benti e Francisco Police, presentes na memória palestrina como integrantes da equipe que disputou a partida contra o Savoia, eram, ao mesmo tempo, na ocasião, jogadores do Corinthians.

Amílcar Barbuy, por exemplo, no ano de 1915, atuou pelo Palestra Itália no dia 24 de janeiro, na partida contra o Savoia ${ }^{402}$, e, em 3 de outubro, contra o Santos. Pelo

\footnotetext{
${ }^{399}$ Correio Paulistano. 18/03/1916. Pág. 3. O Palestra Itália participaria de uma partida amistosa contra o Santos para apresentar a equipe aos moradores da cidade. Na mesma ocasião, informava que a equipe contaria com novos jogadores, sem mencionar os nomes.

${ }^{400}$ Informações do jornalista Celso Dario Unzelte, que passou os dados que levantou quando escreveu os Almanaques do Timão e do Palmeiras. UNZELTE, C. Almanaque do Timão. São Paulo, Ed. Abril, 2000. UNZELTE, C. \& VENDETTI, Mário. Almanaque do Palmeiras. São Paulo, Abril, 2004.

${ }^{401}$ Apud SALUN, A.O. Palestra Itália e Corinthians. Quinta Coluna ou Tudo Buona Gente?Op. Cit. Pág. 34. "1) Os jogadores do primeiro e segundo quadro, bem como seus reservas são isentos de qualquer contribuição quando considerados efetivos nesses quadros pelos diretores de esporte. a) Os jogadores que sem motivo justificado, faltarem aos treinos ou aos matches ficarão sujeitos às penas que serão impostas pela diretoria. b) Jogador algum poderá comprometer-se para jogar em clube estranho, sem prévio consentimento da diretoria. c) Os jogadores recorrerão à diretoria todas as vezes que julgarem injustas as resoluções dos capitães e diretores esportivos."

${ }^{402}$ Una superba affermazione della Palestra Itália. Fanfulla. 25/01/1915. Pág. 6.
} 
Corinthians, atuou em 14 de fevereiro contra a A.A. Caçapavense; em $1^{\circ}$ de maio contra a A.A. das Palmeiras; em 26 de junho, contra o The Wanderers; em 4 de julho, contra o Paulista de São Carlos; em 15 de agosto, contra o Ideal Club; em 5 de setembro, contra o Corinthians de Jundiaí; em 19 de setembro ,contra o Guarani, em 17 de outubro, contra a seleção da APEA; em 24 de outubro, novamente contra a seleção da APEA. Filiou-se ao Palestra Itália em 13 de janeiro de 1915, ao que tudo indica, para atuar na partida contra o Savoia. ${ }^{403}$

Américo Fiaschi também atuou pelo Palestra Itália contra o Savoia e contra o Santos. Filiou-se ao Palestra Itália na mesma ocasião que Amílcar Barbuy, em 13 de janeiro de 1915. Pelo Corinthians, atuou nas mesmas partidas que Amílcar, excetuando a disputada contra o Guarani, em 19 de setembro. Fúlvio Benti, pelo Palestra Itália, jogou contra o Savoia em 24 de janeiro e contra o Santos em 3 de outubro. Seu nome, porém, aparece entre os convocados para treinarem pelas equipes internas do Palestra Itália desde novembro de $1914 .{ }^{404}$ Pelo Corinthians, apenas não disputou as partidas contra o Paulista de São Carlos e contra o Ideal Club.

Bianco Spartaco Gambini - ou apenas Bianco, que era um apelido; alguns jornais também grafam seu nome Bianchi ou o apresentam como Gambini, pelo Palestra Itália, em 1915; disputou a partida contra o Savóia em 24 de janeiro e a partida contra o Paulistano em 29 de junho. Pelo Corinthians, disputou as mesmas partidas de Amílcar, exceto contra a equipe do The Wanderers, em 26 de junho. Sua trajetória como jogador é inusitada. Filiou-se ao Palestra Itália em setembro de $1914,{ }^{405}$ tomou parte do campeonato interno organizado pelos dirigentes palestrinos para selecionar os jogadores que deveriam participar das partidas oficiais pelo Palestra Itália, sendo eleito capitão do time em 13 de dezembro. Pela a análise do Fanfulla, percebemos que o jogador atuava pelas duas equipes, chegando a treinar pela manhã pelo Palestra Itália e a jogar pelo Corinthians na parte da tarde. ${ }^{406}$ Também foi eleito capitão do time do Corinthians em abril de 1915 e, no ano seguinte, também em abril, diretor esportivo do alvinegro e,

\footnotetext{
${ }^{403}$ Palestra Itália. Un prossimo match. Nuovi soci-allenamenti. Fanfulla. 15/01/1915. Pág. 6.

${ }^{404}$ Palestra Itália. Fanfulla. 23/11/1914. Pág. 5.

405 Palestra Itália. Fanfulla. 04/10/1914. Pág. 6. Lista com os nomes dos associados aceitos em reunião no dia 29 de setembro de 1914.

406 Fanfulla. 14/11/1914. Pág. 5. Publicava o anúncio do Palestra Itália convocando o jogador para participar do treino que ocorreria na parte da manhã do dia 15. Fanfulla. 15/11/1914. Pág. 7. O jornal anuncia o nome de Bianco como um dos escalados para jogar pelo Corinthians no mesmo dia.
} 
nessa ocasião, era o único jogador corintiano que atuava simultaneamente pelas duas equipes.

Francisco Police, pelo Palestra Itália, jogou contra o Savoia, contra o Paulistano e contra o Santos. Foi convocado a treinar pelo Palestra Itália em dezembro de $1914 .{ }^{407}$ Pelo Corinthians, atuou nas partidas contra a A.A. Caçapavense, contra a A.A. das Palmeiras, contra o The Wanderers, contra o Guarani e as duas vezes contra a seleção da APEA. Desde abril de 1915, Police exercia a função de diretor esportivo do Corinthians, para a qual foi reeleito em abril de 1916, ao lado de Bianco e Manuel Nunes, o Neco. ${ }^{408}$

Ao longo do ano de 1915, o Palestra Itália realizou poucas partidas. A Primeira Guerra Mundial tomava proporções catastróficas para os países envolvidos no conflito e as comunidades imigrantes não passavam despercebidas. O clube Germânia, por exemplo, sentiu os efeitos do conflito já em agosto de 1914. Parcela enriquecida da comunidade italiana passou a mobilizar-se em torno do Comitato Italiano Pró-Pátria, a Cruz Vermelha Italiana. Em junho daquele ano, as partidas Palestra Itália x Club Athlético Paulistano e Sport Club Corinthians Paulista $\mathrm{x}$ The Wanderers, realizadas no Velódromo Paulista, tinham por objetivo arrecadar fundos para o Comitato e para a Cruz Vermelha, e atrair o público para dar aspecto popular à festa, de tal forma que os preços dos ingressos eram módicos. ${ }^{409}$ A partida contra o Santos também tinha sua renda destinada aos esforços de guerra da comunidade italiana. ${ }^{410}$

Os resultados palestrinos nos gramados naquele ano não foram satisfatórios. Além da derrota para o Paulistano, a goleada sofrida diante do Santos, na partida de três de outubro, ${ }^{411}$ colocou em risco o projeto elaborado pela diretoria de ingressar na APEA. As mudanças que ocorreram na equipe nos meses seguintes, ao que tudo indica, o foram em decorrência dos péssimos resultados. Além de eleições gerais para a

\footnotetext{
${ }^{407}$ Palestra Itália. Fanfulla. 4/12/1914. Pág. 6.

${ }^{408}$ Sports. Correio Paulistano. 7 de abril de 1916. Pág. 3.

${ }^{409}$ Palestra Itália. Fanfulla. 19/06/1915. Pág. 4. La festa sportiva della Palestra Itália e del Club Athlético Paulistano ao Velodromo. Fanfulla. 24/06/1915. Pág. 4.

${ }^{410}$ ARAÚJO, José Renato de Campos. Imigração e futebol. O caso Palestra Itália. Pág. 92.

${ }^{411} \mathrm{O}$ resultado foi de 7 x 0 para o Santos. O periódico Fanfulla não noticiou o resultado no dia seguinte. Essa foi a última partida em que jogadores corintianos colaboraram com o Palestra Itália atuando simultaneamente pelo Corinthians. É preciso salientar que, naquela ocasião, o Corinthians tentava se transferir da LPF para a APEA.
} 
constituição do novo Conselho Diretivo, em 16 de dezembro de $1915,{ }^{412}$ a equipe apareceu completamente remodelada para o ano seguinte. Dos jogadores corintianos, o único que permaneceria no elenco palestrino em 1916, foi Bianco. ${ }^{413}$

Por intermédio de anúncios no Fanfulla, a diretoria convocava os jogadores de origem italiana a ingressar na equipe para disputar o campeonato da APEA de 1916.

"Questa florente associazone calcistica italiana sta attivando tutti gli sforzi per organizzare una forte squadra di footballers allo scopo difare il suo debutto nei Campeonati della Associazone Paulista di Sports Atletici con onore ed efficacia (...) Ocorre per giungere a tale resultato l'appoggio dei bravi giuocatori italiani che si trovano suddivisi in varie altre società non italiane."

Em abril daquele ano, os jogadores convocados para os treinamentos foram Ricco, Valle I, De Nardi, Navarria, D’Andrea, Grimaldi, Filippo, Merlini, Grossi, Fabbri I, Fabbri II, Delascio, Vescovini, Bernanrdini, Cestari, Radames, Gobbato, Virgílio, Turcato, Saguori, Olivieri, Forte I, Forte II, Salerno, Valeri, Assari, Borba, Procido, Nardelli, Russo, Zerlini, Grandi e Valle II. ${ }^{415}$

Há fortes indícios da existência de um circuito futebolístico varzeano franqueado àqueles jogadores que se destacavam nas partidas, pois, no decorrer da pesquisa, não foi difícil encontrar jogadores atuando por dois ou mais times ao mesmo tempo. Em algumas ocasiões, jogadores de Corinthians e Palestra Itália chegavam a atuar pela mesma equipe varzeana nos bairros em que moravam, como nos casos de Neco, Apparício, Police e César, do Corinthians, que atuaram ao lado de Fabrinni (goleiro do Palestra Itália) pela equipe Scraths, do Bom Retiro em partida disputada contra a A.A.

\footnotetext{
${ }^{412}$ Palestra Itália. Fanfulla. 14/12/1915. Pág. 6.

${ }^{413}$ Palestra Itália. Fanfulla. 26/09/1915. Pág. 7. Ainda por ocasião do jogo contra o Santos, os jogadores corintianos foram convocados pela diretoria para o treinamento que definiria os quadros palestrinos para a partida. Nessa ocasião, surgiram, pela primeira vez, alguns dos nomes que ficariam famosos por atuarem no Palestra Itália. Os convocados foram: Stillitano, Nilo, Valle I, Valle II, Bonato, Menossi, Teto, Isola, Fragassi, Olivieri, Polliú, Benti, Felix, Antognoli, Arletta, Emmo, Russo, Américo, Fiaschi II, Amilcar(e), Giacinto, Urbano, Italo, Ferrè, Imparato, Pastore, Primo, Bianco, Valeri, Baroni, De Rinaldi, Fabbi I, Dadesco, Carbone e Sadatini. Os motivos para que os jogadores corintianos desistissem de atuar pelo Palestra Itália não estão claros e a documentação é lacunar.

${ }^{414}$ Palestra Itália. Fanfulla. 11/03/1916. Pág. 5.

415 Palestra Itália. Fanfulla. 08/04/1916. Pág. 5. Quase todos eram novos sócios, aceitos na mesma ocasião em que eram convocados para treinar.
} 
Brazopolitana. ${ }^{416}$ Fragassi e Russo que apareciam com frequência nas convocações palestrinas também atuavam pelo Ítalo F. C. ${ }^{417}$

No período estudado, eleições foram regularmente organizadas dentro do clube para a escolha do conselho diretivo. Em 21 de outubro de 1916, foram eleitos aqueles que comandariam o clube no biênio seguinte. ${ }^{418}$ Dentre os eleitos, afiguram nomes e sobrenomes de alguns que atuavam no time ou eram convocados para os treinamentos, como Ettore, Russo e Ferrè. Dados que contestam os argumentos de Salun de que havia uma especialização maior na direção do Palestra Itália, comparativamente à direção corintiana, estariam invalidados.

Foi no Campeonato Paulista de 1917 que as equipes do Palestra Itália e do Corinthians se enfrentaram pela primeira vez. A vitória palestrina por $3 \times 0$ foi surpreendente, pois o Corinthians chegara ao campeonato com fama de imbatível, depois de vários meses sem perder uma partida na Várzea ou na Liga Paulista de Futebol. ${ }^{419} \mathrm{O}$ resultado não foi suficiente para criar animosidades entre as equipes, pois, na ocasião, o Fanfulla propôs a organização de um combinado Palestra-Corinthians para a disputa de uma partida amistosa contra a equipe argentina do C.S. Barracas. ${ }^{420}$

A notícia deixa transparecer que o resultado não foi bem recebido dentro do Corinthians. Segundo o Fanfulla,

"Il giuoco ebbe luogo e, adesso è inutile ripetere ciò que tutti gli appassionati di questo genere di sport sanno a menadito: la Palestra Italia, contro l'aspettativa di tutti gli sportmen aleuni dei quali avevano fatto delle forti scommesse sul team campione dell'estinta Lega Paulista - a gioia é consolazione dei suoi torcedores, vinse strepitosamente e brillantemente il Corinthians con il bello score di 3 a 0 . (..) Mentre questo fatto serviva di stimulo pei giovanni players, italiani nel seno

\footnotetext{
${ }^{416}$ I matches di domani. Fanfulla. 13/05/1916.

417 Liga Paulista de Futebol. Fanfulla. 01/10/1916. Pág. 5. O time do Ítalo. F.C. era composto por Arnaldo, Beraldi, Taddeo, Bartolomeo, Fragassi, Ciasca I, Ciasca III, Russo, Orlando, Bruno e Mário.

418 L'elezione della Palestra Itália. Fanfulla. 22/10/1916. Pág. 6. Foram eleitos: "Vincenzo Frontini (presidente), Lodovico Bacchinni (vice-presidente), Luigi Cervo (secretário), Ercole Russo (vicesecretário), Ettore de Vecchi (tesoureiro), Giosué de Vecchi (vice-tesoureiro), Ernesto Giuliano (economista), Ernani Comodo (diretor esportivo), Giuseppe Roberti (diretor esportivo), Gaetano Diciatteo (conselheiro), Diulio Frugoli (conselheiro), Guido Sarti (conselheiro), Ing. Giuseppe Ferrè (sindicati), Egisto Romanini (sindicati) e Marte del Carlo (sindicati)."

${ }^{419}$ La Palestra Itália vince il campione della Lega Paulista per 3 a 0. Fanfulla. 07/05/1917. Pág. 3. Os gols foram marcados por Caetano/Gaetano.

${ }^{420}$ Palestra - Corinthians contro C.S. Barracas. Fanfulla. 09/05/1917. Pág. 6. A partida não ocorreu por desistência da equipe argentina.
} 
dei giuocatori del team di Amilcar (jogador do Corinthians) faceava nascere più sorpresi che addolorati - la volontà ferrea di prendersi una rivincita; setimento questo più che naturale - anzi lodevole - nei vinti."

$\mathrm{O}$ segundo jogo entre as duas equipes, realizado naquele mesmo ano, também terminou com triunfo palestrino, desta vez por $3 \times 1 .^{422}$ Para aquela partida, um pelotão da cavalaria foi utilizado para impedir a invasão do campo por torcedores que não conseguiram ingressos. ${ }^{423}$ A partida foi aguardada com grande intensidade pelos torcedores das duas equipes. Segundo a nota do Fanfulla, na ocasião, o Corinthians montou a equipe da melhor maneira que pôde, preparando-se intensamente para a partida. Pelo o exposto n'A Gazeta Esportiva em dezembro de 1929, verificamos que, em 1917, o Corinthians encontrava algumas dificuldades dentro do Campeonato com seu quadro. Não ficou claro se a crise se relacionava com a equipe que envelhecia, com o fato de os jogadores se envolverem com a construção do campo da equipe na Chácara da Floresta e, por isso, não ter a mesma competitividade que os jogadores de equipes como o Palestra Itália e o Paulistano, ou se o modelo diretivo existente no clube impedia uma maior competitividade. ${ }^{424}$

No ano de 1917, a equipe do Palestra Itália recebeu o reforço de diversos jogadores oriundos do Ruggerone F.C. da Lapa, como Picagli, Ministro, Caetano e Martinelli. Do Americano, veio Heitor. ${ }^{425}$ Com a equipe bem montada, além de ganhar do Corinthians nas duas vezes em que se enfrentaram, o Palestra Itália conseguiu triunfar sobre o Paulistano no primeiro turno e acabou o campeonato em segundo lugar.

Por mais que se esforçasse para manter um discurso de serenidade e a prática de cordialidade entre os dirigentes e jogadores das duas equipes, alguns textos no Fanfulla explicitam que, entre os grupos de torcedores que se aglutinavam no entorno das duas equipes, a relação não era tão pacífica. Quando anunciou a formação de um combinado Palestra-Corinthians para enfrentar o Paulistano em um jogo beneficente em outubro de 1917, ao exaltar a atitude cordata das diretorias de Corinthians e Palestra Itália e criticar

\footnotetext{
${ }^{421}$ La Palestra Itália batte per la seconda volta il Corinthians Paulista. Fanfulla. 06/08/1917. Pág. 3.

${ }^{422}$ La Palestra Itália batte per la seconda volta il Corinthians Paulista. Fanfulla. 06/08/1917. Pág. 3. O derby do Campeonato Paulista. Corinthians x Palestra. A Gazeta Esportiva. 01/12/1929. Pág. 4.

${ }^{423}$ La Palestra Itália batte per la seconda volta il Corinthians Paulista. Fanfulla. 06/08/1917. Pág. 3.

${ }^{424} \mathrm{O}$ derby do Campeonato Paulista. Corinthians x Palestra. A Gazeta Esportiva. 01/12/1929. Pág. 4. " $O$ Corinthian,s por esta época, atravessava uma crise em seu quadro devido à nova organização."

${ }^{425}$ MAZZONI, T. Palestra Itália. Pág. 6. O Fanfulla o chamava de Ettore.
} 
a postura violenta de alguns torcedores das duas equipes, o periódico deixou transparecer que os ânimos já estavam acirrados entre os simpatizantes das duas equipes naquela ocasião ${ }^{426}$.

A partir do Campeonato Paulista de 1918, as partidas entre Corinthians e Palestra Itália adquiriram um grau de dramaticidade, competição e violência que não existiam previamente. Ao que tudo indica, pelos aspectos de falso amadorismo ou profissionalismo marrom, os jogadores passaram a ser cobrados pelos resultados pelos dirigentes. Ao mesmo tempo, as torcidas e aqueles que pagavam ingresso se inflamavam e cobravam maior empenho e resultados. Naquele ano, a única partida disputada entre as duas equipes no Campeonato Paulista ficou marcada pela violência e terminou empatada em $3 \times 3 .{ }^{427}$ As duas partidas disputadas na inauguração do campo corintiano na Chácara da Floresta foram marcadas por bom público, estimado em cerca de cinco mil pessoas, e pela renovação da equipe corintiana. Na primeira partida, em uma disputa equilibrada, houve empate em 3 X 3. A segunda foi vencida pelo Palestra Itália por 4 X $2 .^{428}$ Após essa última partida, foi realizado um banquete em que os jogadores das duas equipes celebraram a inauguração da praça desportiva corintiana.

A segunda partida do Campeonato Paulista entre as duas equipes não foi disputada porque o Palestra Itália abandonou o campeonato e a APEA após a partida contra o Paulistano, disputada em 30 de junho de 1918. Na sequência desse episódio, o Fanfulla publicou algumas notas sobre os procedimentos do Paulistano em relação às normas vigentes na APEA, acusando-o de não respeitar o regimento da entidade em diversas ocasiões sem ser questionado por tais atos. ${ }^{429}$ Nos meses subsequentes, a diretoria palestrina organizou diversas festas para os associados, que segundo o

\footnotetext{
${ }^{426}$ Combinato Palestra-Corinthians contro C.A. Paulistano. Fanfulla. 11/10/1917. Pág. 5.

${ }^{427}$ O derby do Campeonato Paulista. Corinthians x Palestra. A Gazeta Esportiva. 01/12/1929. Pág. 4. O Palestra Itália abandonou o Campeonato, razão pela qual a segunda partida não foi disputada.

${ }^{428}$ O MAZZONI, T. Palestra Itália. Pág. 8. O autor comete um engano ao informar que as partidas ocorreram em 1919. As datas corretas das partidas de inauguração do campo do Corinthians na Chácara da Floresta são 17/03/1918 e 24/03/1918. Ver também Col primo match amichevole di quest'anno si inaugura quest’oggi il ground del Corinthians Paulista. Fanfulla. 17/03/1918. Pág. 7. Il Corinthians ha inaugurato ieri il ground pareggiando com la Palestra Italia per 3 a 3. Fanfulla. 18/03/1918. Pág. 5. Un'altra bella palma di vittoria conquista la Palestra Italia sconfiggendo il Corinthians per 4 a 2. Fanfulla. 25/03/1918. Pág. 6.

${ }^{429}$ Il Paulistano e l'APSA. Fanfulla. 16/07/1918. Pág. 4. Depoimento que confirma nossa posição em capítulo anterior, sobre o discurso do Paulistano pró-amadorismo.
} 
periódico, atraíram para o Parque Antarctica cerca de dez mil pessoas. ${ }^{430}$ Foi neste contexto que pela primeira vez, o jornal publicou manifestos de simpatizantes propondo a construção de um estádio para o Palestra Itália ${ }^{431}$.

Apenas em 1919, o Corinthians ganhou sua primeira partida contra o Palestra Itália, em um dos jogos-treino que serviram de preparativo para o Campeonato Paulista. $^{432} \mathrm{O}$ segundo jogo-treino foi vencido pelo Palestra Itália, assim como o primeiro jogo pelo Campeonato Paulista. ${ }^{433}$ A última partida entre as duas equipes naquele ano foi disputada no segundo turno daquele Campeonato Paulista. Esta foi a primeira vitória oficial corintiana e teve gosto amargo para o Palestra Itália. A equipe palestrina, no decorrer do torneio, chegou a abrir boa vantagem em relação ao segundo colocado e a derrota para o Corinthians foi fundamental para que a equipe perdesse o campeonato para o Paulistano. ${ }^{434}$ Marcada pela violência, com direito a briga entre os jogadores palestrinos ${ }^{435}$, a partida resultou na suspensão do jogador corintiano Neco por três partidas. ${ }^{436}$

Em 1920, ano em que o Palestra Itália conquistou seu primeiro título, a partida contra o Corinthians pelo segundo turno, em pleno Parque Antarctica, recém-adquirido pela equipe palestrina, também foi marcada pela violência e quase abriu uma crise no meio da APEA. $^{437}$ Ainda naquele ano, as equipes disputaram a preferência dos jogadores ítalo-paulistas, e Gambarota, jogador do Itália F.C., equipe que disputava a segunda divisão, anunciou sua preferência em atuar pelo Corinthians. ${ }^{438} \mathrm{Na}$ mesma

\footnotetext{
${ }^{430}$ La significativa dimostrazione di simpatia fatta ieri allá Palestra Itália. Fanfulla. 22/08/1918. Pág. 6.

431 Per lo stadium palestrino. Fanfulla. 05/07/1918. Pág. 6. Per lo stadium palestrino. Fanfulla. 06/07/1918. Pág. 5.

${ }^{432}$ Lo scontro Palestra Corithians allá Floresta. Fanfulla. 04/05/1919. Pág. 6. As duas equipes jogaram desfalcadas de seus principais jogadores, que estavam defendendo a Seleção Brasileira no Sul-americano do Rio de Janeiro.

${ }^{433}$ Lo scontro Palestra Corinthians. La magnífica vittoria palestrina per 2 a 1. Fanfulla. 14/05/1919. Pág. 4. Il Palestra Itália sconfi il Corinthians Paulista per lo score di 1 a 0. Fanfulla. 21/07/1919. Pág. 5.

${ }^{434}$ Lo scontro Palestra Corinthians all'Antarctica. Fanfulla. 10/11/1919. Pág. 3. O Palestra Itália perdeu na semana seguinte, para o Paulistano a liderança do Campeonato. Em 21 de dezembro, as esperanças palestrinas foram depositadas na atuação do Corinthians contra o Paulistano, mas, com a vitória sobre o Corinthians, o Paulistano ganhou novamente o título. Naquela ocasião, o periódico criticou a atuação corintiana diante do Paulistano. Brillantissima vittoria del Paulistano. Fanfulla. 22/12/1919. Pág. 5.

${ }^{435}$ Ministro e Caetano esbofetearam-se no intervalo do match de domingo? A Gazeta. 11/11/1919. Pág. 3.

${ }^{436}$ Neco foi suspenso. A Gazeta. 14/11/1919. Pág. 3.

${ }^{437}$ MAZZONI, T. Palestra Itália. Op. Cit. Pág. 9.

${ }^{438}$ Gambarota jogará no Palestra ou no Corinthians. A Gazeta. 06/01/1920. Pág. 3.
} 
ocasião, o Palestra Itália anunciou seu interesse por dois jogadores da equipe do Corinthians: Russo e Nando. ${ }^{439}$

Em 1921, a equipe palestrina não conseguiu repetir o desempenho do ano anterior. As vitórias sobre o Corinthians, no entanto, impediram que esta equipe alcançasse o título daquele ano, que ficou com o Paulistano. ${ }^{440}$ Nos anos seguintes, o mesmo processo que se abatera sobre a equipe corintiana a partir de 1917 abateu-se sobre o Palestra Itália. A renovação da equipe corintiana combinada com o envelhecimento e a decadência da equipe palestrina enfraqueceram sua capacidade competitiva. Foi a vez de o Corinthians triunfar sobre seus rivais e conquistar títulos seguidos.

$\mathrm{Na}$ década de 1930, a equipe palestrina voltou a ascender e consolidou certa hegemonia sobre a equipe do Corinthians. Naquela década, a maior goleada já registrada em um derby, em favor do Palestra Itália, resultaria na queda de toda a diretoria corintiana, em 1933: 8 X 0. ${ }^{441}$ Em 1940, a hegemonia palestrina nos confrontos com o Corinthians era inquestionável. Em 41 partidas disputadas, o Palestra Itália acumulou 21 vitórias contra 12 vitórias corintianas ${ }^{42}$. O imaginário do Palestra Itália como o grande time da comunidade ítalo-paulista ficou consolidado e a do Corinthians como time popular também.

\subsection{As relações com a família Matarazzo e outros industriais italianos.}

Na pesquisa sobre o Palestra Itália, algumas situações chamaram a nossa atenção. Primeiramente, o envolvimento do Fanfulla, periódico da comunidade italiana em São Paulo no projeto. O volume de material sobre o Palestra Itália publicado ali contrasta com o publicado nos demais periódicos da cidade ${ }^{443}$ ou com o que o próprio periódico

\footnotetext{
${ }^{439}$ Palestra Itália queria os dois jogadores do Corinthians Paulista. A Gazeta. 27/01/1920. Pág. 3.

${ }^{440}$ MAZZONI, T. Idem. Ibidem.

${ }^{441}$ UNZELTE, C. Almanaque do timão. Pág. 83.

${ }^{442}$ Palestra e Corinthians. A Gazeta Esportiva. 17/08/1940. Pág. 11.

${ }^{443}$ CARELLI, M. Op. Cit. Pág. 62. Segundo o autor, o Fanfulla começou a circular em 17 de maio de 1894, fundado pelo jornalista Vitaliano Rotellini, que angariou prestígio em São Paulo e que, em 1898, candidatou-se à presidência do Estado. Embora não tenha sido eleito, desde então teria se transformado numa espécie de conselheiro político. Em 1910, o Fanfulla tinha a segunda maior tiragem diária de São Paulo (15 mil), atrás apenas de $O$ Estado de S. Paulo (20 mil). Caracterizava-se pelo anticlericalismo e liberalismo. TRENTO, A. Do ouro lado do Atlântico. Um século de imigração italiana no Brasil. Pág.
} 
publica acerca de outros times. A segunda questão que chama a atenção é como foi articulado, no decorrer dos anos, os nomes dos fundadores e militantes em torno do clube. Como exemplo, em 1964, o clube publicou o Álbum Comemorativo das Bodas de Ouro, em que informa os nomes considerados sócios fundadores do clube em agosto de 1914: Armando Rebucci, Benedetto Rizzo, Vicenzo Rizzo, Gennaro Romano Filho, Ezequiel Simone, Michele Taxolaro, Oberdan Zamboni, Antonio Aulicinio, Giovanni Barsanti, Delfo Betti, Amadeo Bucciarelli, Francesco Camargo, Magno A. Carlo, Luigi Cervo, Michele A. Cielo, Vicenzo Cilento, Dante Corazza, Alfonso de Azevedo, Clementino del Cielo, Francesco de Vivo, Eugênio Gallo, Antonio Gallucci, Giorgio Gianetti, Giulio Gianetti, Giulio Gianetti (sic), Pietro Gregoracci, Adolfo Izzo, Alfredo Izzo, Luigi Izzo, Giovanni Lamacchia, Onofrio Lilla, Battista Mannini, Luigi Emanuele Larzo, Luigi Medici, Luigi (fu Rosario) Medici, Alfredo Migliori, Francesco Morelli, Alfonso Mosca, Attista (ou Battista?) Nannini, Giuseppe Nigro, Giuseppe Prince, Giovanni Principato e Vincenzo Ragognetti. ${ }^{444}$

O mesmo livro informa que alguns daqueles que não compareceram à histórica assembleia de criação do Palestra Itália, em 26 de agosto de 1914, por causas imprevistas ou imprevisíveis, foram considerados e, oficialmente, declarados sóciosfundadores por benemerência: Biagio Alario, Biagio Altieri, Ippolito R. Costa, Adriano Crespi, Rodolfo Crespi, J. M. Doganiero Michele da Cunha, Menotti Falchi, Antonio G. de Gouveia, Vincenzo Latuchella, Alexandro Marcondes Filho, Andréa Matarazzo, Ermelino Matarazzo, Eduardo Matarazzo, Francisco Matarazzo, Giulio Pignatari, Nicola Serrichio Alessandro Siciliano, Paulo Siciliano, Arturo Spengler, Federico Tommaselli, Federico Tommaselli (sic), Giuseppe Tommaselli, Guilherme Kawall e Rodolfo Kesserling.

191. O autor afirma que o periódico começou a circular em 1893 e, rapidamente, angariou prestígio na comunidade italiana por sua seriedade e pelo trabalho de denúncia das condições que viviam os italianos em São Paulo. Afirma, também, que o jornal sempre defendeu o processo de assimilação dos italianos na sociedade paulistana, mesmo na época do fascismo, quando adotou postura mais nuançada. Pág. 198. Apenas em 31 de agosto de 1941, o periódico foi publicado em português na íntegra. Pág. 395. ARAÚJO, J. R. C. Imigração e futebol. O caso Palestra Itália. O capítulo trata das relações entre imprensa e futebol, defende a ideia de que o clube sofria restrições de periódicos como "Correio Paulistano" e "O Estado de S. Paulo".

444 Jubileu de ouro. Sociedade Esportiva Palmeiras (1914-1964). A obra foi escrita por diversos colaboradores. Quando houver a referência do autor, ele será citado. Neste caso, não há qualquer referência ao responsável pelas informações. 
Muitos dos nomes citados são conhecidos por aqueles que estudam a história da cidade de São Paulo no século XX. Quase todos obtiveram destaque em suas atividades como empresários ou comerciantes e alguns amealharam títulos de nobreza oriundos da Itália e outros de comendadores.

Mazzoni, em sua obra, publicada em 1950, e que serve de base para quase todo material divulgado posteriormente, afirma que, no dia 13 de agosto de 1914, aparece a seguinte nota no Fanfulla:

"Pela formação de um quadro italiano de futebol em São Paulo. São Paulo, 13 de agosto de 1914. Egrégio Senhor Diretor do Fanfulla (...): Uma palavra apenas e para esta um cantinho de vosso jornal. Eis do que se trata: alguns conhecidos futebolistas italianos, mas, associados a clubes brasileiros, encarregam-me de escrever-vos acerca de um projeto por eles ideado entre dois goles de café, fazendo-me então compreender que de tal projeto, o vosso jornal deverá se tornar o propugnador e o propagandista (...) Nós temos em São Paulo - afirmam os referidos esportistas - o clube de futebol dos alemães, dos ingleses, dos portugueses, dos internacionais e mesmo dos católicos e dos protestantes, mas, um clube que seja exclusivamente de sportmen italianos, e sendo a nossa colônia a maior do Estado, nada se tentou realizar! (...) Futebolistas italianos que jogam bem encontram-se em São Paulo, porque, de comum acordo, não reunimos os referidos senhores, e assim como temos associações do remo, filodramáticas, mundanas, patrióticas etc. etc. de estrutura italiana, poderemos também ter um clube de futebol exclusivamente italiano (...) Aqui fica a proposta dos futebolistas italianos; com v.s., sr. Diretor, o comentário. Vicente Ragognetti."

O periódico responde a carta de Ragognetti com uma pequena nota da redação:

“Approviamo senz' altro quanto espone il signor Ragognetti. Per quento è a nostra conoscenza però aggiungiamo chi giá un importante club di questa capitali sta organizzando un team prettamente italiano."446

No dia 19 de agosto, segundo Mazzoni, aparece o comunicado informando a organização de uma diretoria provisória para a formação de uma sociedade que deveria ser denominada Palestra Itália. Os aderentes até aquele momento se compunham de estudantes e empregados no comércio, que se reuniram naquela noite para eleger a

\footnotetext{
445 MAZZONI, T. Op. Cit. Pág. 98. Per la formazione de uma squadra italiana di foot-ball in São Paulo. Fanfulla. 14/08/1914. Pág. 4. Aparentemente se engana com a data, pois encontramos o artigo em 14/08/1914, não em 13/08/1914.

${ }^{446}$ Per la formazione de uma squadra italiana di foot-ball in São Paulo. Fanfulla. 14/08/1914. Pág. 4.
} 
diretoria provisória e para completar a formação da sociedade. Além disso, a nota informava que funcionários das Indústrias Reunidas Francisco Matarazzo, que eram sócios da Sociedade Recreativa Bela Estrela e estavam descontentes com o direcionamento da entidade, apoiaram a iniciativa de fundação do Palestra Itália. Apenas 37 pessoas teriam participado dessa reunião ${ }^{447}$, número que se repetiria, segundo Mazzoni, na Assembleia Geral realizada a 26 de agosto, que proclamou, oficialmente, a fundação do clube. Números que não batem com os dados publicados pelo clube em 1964, no Álbum do Jubileu de Ouro, que relaciona 43 pessoas, se contarmos apenas os sócios fundadores por direito. Para aumentar a confusão, o mesmo Álbum do Jubileu de Ouro informa que a ata de fundação do clube data de sete de outubro de $1914,{ }^{448}$ contradizendo Mazzoni.

Com o desenvolvimento das atividades da agremiação, o êxito conquistado nos campos e campeonatos e a inserção de novos associados, o clube, no decorrer dos anos, modificou os nomes de seus fundadores, reconstruindo os fatos de acordo com as demandas políticas internas. Evidentemente, muitos dos nomes citados como sócios fundadores beneméritos foram importantes na trajetória do clube, porém não foram fundadores como informava o clube no Álbum do Jubileu de Ouro. Seus nomes ali constavam e ainda constam, provavelmente, em decorrência do prestígio que possuíam na sociedade paulistana nos anos 1960 e não pelo papel que tiveram na fundação do clube. E mais importante: reforçam a ideia de que os italianos que fundaram o Palestra Itália eram socialmente diferentes dos italianos que fundaram o Corinthians.

É evidente que as relações com a família Matarazzo foram fundamentais em momentos cruciais da história do clube, que suscita diversas indagações. Por que os industriais mais bem sucedidos do Brasil no início do século se envolveram com o clube $?^{449}$ Precisar como a família Matarazzo ingressou no Palestra Itália é um pouco difícil, pois sua presença dentro do clube está envolta em relatos míticos que dificultam a compreensão de sua participação. Tentaremos seguir algumas pistas.

\footnotetext{
447 MAZZONI, T. Op. Cit. Pág. 98. Palestra Itália. Fanfulla. 19/08/1914. Pág. 5. Não há qualquer referência à família Matarazzo ou às IRFM, apenas sobre a formação de um comitê para a criação do clube e a adesão de estudantes e funcionários do comércio.

${ }^{448}$ A primeira diretoria. Sociedade Esportiva Palmeiras (1914 - 1964). Álbum Comemorativo Jubileu de Ouro. No álbum, há a alegação de que a ata de outubro é retroativa a 26/08/1914.

${ }^{449}$ COUTO, Ronaldo Costa. Matarazzo. A travessia. São Paulo, Editora Planeta do Brasil, 2003. Pág. 30. Em 1920, Francesco Matarazzo era o italiano mais rico do mundo e era melhor conceituado que a maioria dos industriais em São Paulo. Pág. 33.
} 
Através do depoimento do cônsul italiano em São Paulo, Gherardo Pio Savóia, descobrimos que os italianos enriquecidos disputaram poder e prestígio junto ao restante da comunidade italiana desde o início do século. ${ }^{450}$ As razões das disputas passavam pelos aspectos financeiros mais imediatos, como o controle das remessas em dinheiro que os italianos radicados no Brasil realizaram periodicamente para a Itália $^{451}$ e os lucros que tais operações geravam, ou a construção de identidades patronais que esvaziassem ou minimizassem os apelos dos discursos anarquistas ou comunistas entre os operários.

A imigração de italianos para São Paulo entre as últimas décadas do século XIX e as primeiras do século XX apresenta algumas características importantes. A imensa maioria que da Itália partia buscava alguma alternativa ao processo de proletarização em curso no país de origem, desde a unificação. Chegavam com o sonho de adquirir uma pequena propriedade ou abrir um pequeno negócio e, somente quando nada disso acontecia, se rendia à proletarização e se transformavam em operários. ${ }^{452}$ É importante reiterar que apenas os que aportaram com algum capital conseguiram ascender socialmente, mas todos que ficaram em São Paulo, com o passar dos anos, foram incorporados de uma forma ou de outra à paisagem da cidade, assim como seus descendentes. $^{453}$

As greves dos operários em São Paulo eram constantes nas primeiras décadas do século XX. As condições precárias de trabalho e de vida dos operários aliadas ao rápido enriquecimento de alguns empresários criaram situações potencialmente explosivas para os donos do poder. Entre 1917 e 1920, o Estado de São Paulo vivenciou setecentas greves parciais e duzentas greves gerais. ${ }^{454} \mathrm{Em} 1917$, os grevistas das fábricas Crespi

${ }^{450}$ COUTO, Ronaldo Costa. Matarazzo. Colosso Brasileiro. Págs. 20 e 21. TRENTO, A. Op. Cit. Pág. 289. Chegavam a trocar farpas pelos periódicos da comunidade. Págs. 288 e 289.

${ }^{451}$ COUTO, Ronaldo Costa. Idem. Ibidem. Desde 1906, Francesco Matarazzo mantinha a representação do conceituado Banco di Napoli e administrava, na forma de monopólio, a remessa de dinheiro dos italianos no Brasil para a Itália.

452 ALVIM, Zuleika M. F. O Brasil Italiano (1880 - 1920) (In): FAUSTO, B. Fazer a América. A imigração em massa para a América Latina. Pág. 404. BERTONHA, João Fábio. O fascismo e os imigrantes italianos no Brasil. Porto Alegre, EDIPUCRS, 2001. Pág. 17. Os autores informam que o volume de italianos que abandonaram o Brasil foi imenso, algo próximo a 1/3 dos que ingressaram.

453 ALVIM, Zuleika M. F. O Brasil Italiano (1880 - 1920) (In): FAUSTO, B. Fazer a América. A imigração em massa para a América Latina. Op. Cit. Pág. 404. Em 1920, segundo a autora, de cada quatro habitantes de São Paulo, um era estrangeiro e os italianos representavam $40 \%$ desse total.

${ }^{454}$ CARElli, M. Carcamanos \& Comendadores. Op. Cit. Pág. 65. SIMÃO, Azis. Sindicato e Estado, quadro p. 182 e apêndices p. 253-272. Segundo os autores, em 1919 foi aprovada lei que protegia os 
exigiam o fim da contribuição compulsória pró-pátria que os comitês liderados pelos empresários descontavam dos empregados italianos. ${ }^{455} \mathrm{O}$ próprio Francisco Matarazzo foi alvo de diversos boicotes que seus funcionários organizaram por todo o Estado contra seus produtos. ${ }^{456} \mathrm{E}$ desde aquela ocasião, diversos segmentos da comunidade ítalo-paulistana denunciavam a utilização do patriotismo dos pobres italianos da cidade pelos grupos endinheirados italianos ou paulistanos. ${ }^{457}$

O ideal de italianidade sempre foi alimentado por representantes diplomáticos do governo italiano, financiadores e empresários italianos de São Paulo. ${ }^{458}$ Desde 1907, por exemplo, Francisco Matarazzo apelava para o discurso da identidade italiana para esvaziar movimentos grevistas dentro de suas empresas ${ }^{459}$. Fazia parte de seu discurso a construção de identidades patronais que lhe assegurassem o controle sobre o volume de operários que trabalhavam em suas fábricas, majoritariamente italianos ou descendentes. A combinação desse ideal de italianidade com a ideologia do self-mademan se articula na construção de diversos mitos relacionados à família Matarazzo, alguns dos quais são importantes para esta pesquisa. ${ }^{460}$

Alguns pesquisadores da imigração italiana afirmam que os clubes desportivos cativaram os italianos de São Paulo e arregimentaram o maior número de sócios dentre

trabalhadores que fossem vítimas de acidentes de trabalho, leis que não foram respeitadas pelos empresários por alguns anos. Págs. 74 e 81 do livro do Azis. ALVIM, Zuleika M. F. O Brasil Italiano (1880 - 1920) (In): FAUSTO, B. Fazer a América. A imigração em massa para a América Latina. Pág. 407. A autora informa que, por ocasião da greve de 1917, um comitê de defesa proletária chegou a ser organizado. Na página 409, a autora informa que, entre 1890 e 1920, 82\% dos líderes sindicais eram estrangeiros e que, dentre estes, $61 \%$ eram italianos; MARTINS, José de Souza. Conde Matarazzo. $O$ empresário e a empresa. Pág. 89. O autor chama a atenção para o fato de que as greves mais significativas que ocorreram em São Paulo, até 1930, ocorreram na proporção de 62,3\% entre 1911 e 1920 e apenas 11,5\% entre 1921 e 1930; LOPREATO, Christina da Silva Roquette. A semana trágica. A greve geral anarquista de 1917. Pág. 75. Nota de rodapé 48 informa que o Fanfulla calculava em cerca de cem mil trabalhadores paralizados em São Paulo entre os dias 9 e 16 de julho de 1917.

455 CARelli, M. Op. Cit. Pág. 47; FAUSTO, B. Op. Cit. Pág. 193; TREnTO, A. Op. Cit. Pág. 287. LOPREATO, Christina da Silva Roquette. A semana trágica. A greve geral anarquista de 1917. Pág. 25. A autora informa que eram descontados $2 \%$ dos salários de todos os empregados, independentemente da nacionalidade.

${ }^{456}$ MARTINS, José de Souza. Op. Cit. Pág. 99.

${ }^{457}$ CARELLI, M. Op. Cit. Pág. 97.

${ }^{458}$ CARELLI, M. Op. Cit. Pág. 64.

${ }^{459}$ CARELLI, M. Op. Cit. Pág. 47. FAUSTO, B. Trabalho urbano e conflito social. Pág. 151.

${ }^{460}$ MARTINS, José de Souza. Op. Cit. Pags. 9 e 11. Segundo o autor, "o grupo Matarazzo apresenta a característica de que os elementos míticos da biografia do seu personagem central transcenderam os limites orais e marcaram até a literatura mais decente". 
todas as associações criadas pela comunidade naquela época. ${ }^{461}$ Podemos afirmar, pelo volume de material encontrado, que o futebol converteu-se em uma prática muito importante para esses grupos desde o início do século, pois times formados por ítalopaulistas pipocaram pela cidade. Dentre as várias associações, políticas, culturais ou sociais criadas pela comunidade ítalo-paulista, o Palestra Itália foi um dos poucos grupos associativos que persistiu e resistiu aos anos. Talvez seu sucesso possa ser explicado pelo fato de ter se convertido em um espaço de mediação cultural entre os múltiplos atores sociais da comunidade ítalo-paulista, espaço em que o discurso de italianidade ofuscava qualquer discurso classista, mas que não impedia a existência de conflitos internos.

O relacionamento das figuras proeminentes da comunidade italiana, enriquecidas e assustadas com a explosão dos movimentos operários, que eram profundamente marcados pela presença de italianos, com um clube que se identificava como o clube da comunidade italiana passou por esses percalços que a cidade viveu durante a Primeira Guerra Mundial e não foi imediato à fundação do clube, como sugerem os títulos de sócios fundadores por benemerência. O desenhista Voltolino, paulistano e filho de italianos, foi um dos membros da comunidade a denunciar a exploração desta italianidade pelos empresários da comunidade ítalo-paulistana, em charge de 1917. Naquela ocasião, Ermelino Matarazzo, presidente do Comitê Pró-Pátria fora condecorado como presidente de honra do Palestra Itália.

É interessante notar que alguns autores afirmam que o ingresso do Palestra Itália no campeonato de 1916, organizado pela APEA, só foi possível graças à presença de figuras influentes da comunidade italiana em seus quadros, como a família Matarazzo. Segundo esses relatos, o apoio fora decisivo para que a APEA aceitasse o ingresso do clube, ainda mais com a derrota por $7 \mathrm{X} 0$ sofrida diante do Santos, no período de seleção, e que serviria de justificativa técnica para impedir o ingresso do clube na entidade, quando o The Scottish Wanderers foi eliminado por não possuir campo próprio e outros documentos que cumprissem as garantias exigidas pela APEA. ${ }^{462}$ Esses

\footnotetext{
${ }^{461}$ TRENTO, A. Op. Cit. Pág. 290.

462 Sports. Correio Paulistano. 23 de fevereiro de 1916. Pág. 2. Para compreender os motivos da eliminação do Scottish Wanderers.
} 
autores afirmam que o empresário foi transformado em sócio benemérito do clube na seqüência desses eventos. ${ }^{463}$

As fontes sugerem situação um pouco diferente. Luigi Cervo, que era funcionário das Indústrias Reunidas Família Matarazzo (IRFM), ${ }^{464}$ quando o Velódromo foi destruído em 1915, ofereceu os equipamentos, meios de transporte e mão-de-obra à APEA, para que as arquibancadas fossem transportadas e montadas na sede da Chácara da Floresta, nova área destinada pela Prefeitura para a prática de futebol em São Paulo. ${ }^{465}$ Desde então, conseguira da Associação a simpatia e a garantia de que o Palestra Itália poderia ingressar no campeonato da entidade no ano seguinte, além da organização do referido amistoso contra o Paulistano, que já se recusara a enfrentar o Corinthians por diversas ocasiões.

Determinar a participação dos Matarazzo neste episódio é muito difícil. De fato, sem a autorização de algum membro do clã, a infraestrutura das indústrias não poderia ser utilizada para a mudança das arquibancadas do Velódromo para a Chácara da Floresta, pois um subalterno não teria poder para autorizar tais procedimentos. Se isso aconteceu, o responsável pela medida não foi Francisco Matarazzo, mas Ermelino Matarazzo, que assumira o comando das empresas no lugar do pai que se encontrava na Itália desde o final de $1914 .{ }^{466}$ Outro fator a ser levado em consideração é o contexto em que o clube se desenvolvia. Naquela época, em plena Primeira Guerra Mundial, com o forte apelo nacionalista dos Comitês Pró-Itália ${ }^{467}$ e Cruz Vermelha Italiana, dificilmente a família Matarazzo deixaria passar despercebido o potencial agregador que o clube começava a mostrar dentro da comunidade e seu potencial econômico.

De outro lado, a história sobre a influência dos Matarazzo nesse episódio criou uma tradição muito interessante para aqueles que, em determinado momento da história

\footnotetext{
${ }^{463}$ SALUN, A. O. Op. Cit. Pág. 62.

${ }^{464}$ MARTINS, José de Souza. Conde Matarazzo. O empresário e a empresa. Pág. 41. Apenas em 1929, a empresa principal do grupo passou a se chamar S.A. Indústrias Reunidas F.(rancisco) Matarazzo.

${ }^{465}$ Agosto de 1914, o Torino e o Pró-Vercelli influíram na sua fundação. Vida nova para o futebol de São Paulo a partir de 1916. Campeão em 1920. Desde aí... Sociedade Esportiva Palmeiras (1914 - 1964). Álbum Comemorativo Jubileu de Ouro. A publicação não apresenta numeração de páginas. Esta informação consta na página que está ilustrada pela foto de uma partida entre Palestra Itália e São Bento, em 1917.

${ }^{466}$ COUTO, Ronaldo Costa. Op. Cit. Pág. 28.

${ }^{467}$ COUTO, Ronaldo Costa. Op. Cit. Págs. 32 e 122. Segundo o autor, a liderança do Comitê Pró-Pátria era exercida pelo próprio Ermelino Matarazzo. CARELLI, M. Op. Cit. Pág. 45. O autor fala que Alessandro Siciliano também participava intensamente dos comitês.
} 
do clube, entre os anos 1920 e 1930, exerceram o papel de dirigentes e precisavam limitar as críticas da oposição.

O Fanfulla não menciona a participação de qualquer membro do clã entre os dirigentes da agremiação nos primeiros anos. A figura de Ermelino Matarazzo, notório por seu entusiasmo diante dos esportes, aparece, pela primeira vez, relacionada ao Palestra Itália no periódico em novembro de 1916, quando ofereceu uma taça para ser disputada entre a equipe do Palestra Itália e a equipe da A.A. Mackenzie College. ${ }^{468}$ Pelo levantamento efetuado, alguns dos idealizadores e dirigentes pioneiros do Palestra Itália possuíam experiência como dirigentes ou militantes em outras equipes do chamado futebol oficial, como Luigi Cervo, que viera do Internacional. ${ }^{469}$

Somente quando o Palestra Itália completou três anos de existência, na festa de inauguração da nova sede social que ficava na Rua Libero Badaró, Ermelino Matarazzo recebeu o título de presidente honorário do Palestra Itália. ${ }^{470}$ Naquela ocasião, Umberto Serpieri, representante do Fanfulla na festa, convidado para ser o orador da festa, declara:

"Il pensiero che animó gl'iniziatori era generoso e degno di planso; essi volevano collegare in uma organizzazione forte, disciplinata e rigigliosa le energie italiane che già se distinguevano nel campo del football, volevano creare un' Associazione con carattere prettamente italiana che fosse al tempo stresso l'arena delle esereitazioni sportive ed il vincolo saero di una nuova solidarietà patrittica." ${ }^{471}$

Na mesma declaração, Umberto Serpieri fala do apoio do Consulado Geral da Itália e das famílias italianas abastadas no processo de fundação do clube. ${ }^{472}$ Durante a pesquisa, esta foi a primeira vez que encontramos um depoimento relacionando a fundação do Palestra Itália com o Consulado Italiano. Mas não menciona os nomes das famílias abastadas que contribuíram para a fundação do clube, em 1914, e informa que

\footnotetext{
${ }^{468}$ Palestra Itália. Fanfulla. 01/11/1916. Pág. 6.

${ }^{469}$ MAZZONI, T. Op. Cit. Pág. 98.

${ }^{470}$ L'inaugurazione ufficiale della sede sociale della Palestra Itália. Fanfulla. 02/09/1917. Pág. 4. Primeira vez que o dirigente foi anunciado como presidente honorário. É importante que se diga que o presidente de fato, naquela ocasião, segundo o mesmo periódico, era Guido Sarti. Não há qualquer justificativa para a nomeação de Ermelino Matarazzo ao cargo de presidente benemérito.

${ }^{471}$ L'inaugurazione ufficiale della sede sociale della Palestra Itália. Fanfulla. 02/09/1917. Pág. 4.

${ }^{472}$ L’inaugurazione ufficiale della sede sociale della Palestra Itália. Fanfulla. 02/09/1917. Pág. 4.
} 
Vicenzo Ragognetti, um dos proponentes da criação do Palestra Itália, naquela ocasião trabalhava como jornalista do Fanfulla.

As relações da família Matarazzo com a compra do Parque Antarctica também não estão claras. Desde 1919, o Palestra Itália tentava adquirir o Parque Antarctica. Segundo o periódico A Gazeta, de 24 de maio de 1919:

"O novo conselho deliberativo do Palestra Itália está em negociações com os proprietários do campo de foot-ball do Parque Antarctica (...) Sabemos que a directoria da fidalga sociedade está disposta a pagar até 500:000\$000 pelo campo e que tenciona executar diversas obras, tornando-o um perfeito stadium.

O Fanfulla nos surpreendeu por dois motivos: primeiro, pela discrição acerca das negociações entre Palestra Itália e Cia. Antarctica Paulista; segundo, pela possibilidade de verificarmos o surgimento de um movimento pró-estádio dentro do clube, desde $1918 .^{474}$

As discussões do tema causavam controvérsias, pois um dos aspectos expostos desde o início pelos que advogavam a ideia era a necessidade de o Palestra Itália aumentar o valor das mensalidades e das taxas de adesão para arrecadar o dinheiro para a empreitada. ${ }^{475}$ O periódico informa, em abril de 1919, a existência de três opções, sem informar quais eram. ${ }^{476} \mathrm{O}$ clube formou uma comissão que, nos meses seguintes, ficou encarregada de discutir e propor as melhores soluções. Em agosto, a equipe utilizava um dos campos do Parque Antarctica como campo destinado para as atividades sociais ou, em algumas ocasiões, para treinamento da equipe principal. ${ }^{477}$ Em outubro, o periódico anuncia a inauguração do ground palestrino e a divisão dos espaços das arquibancadas destinados à diretoria, aos sócios e famílias e aos demais torcedores. ${ }^{478}$

\footnotetext{
${ }^{473}$ Palestra Itália. A Gazeta. 24/05/1919. Pág. 2.

${ }^{474}$ Per lo stadium palestrino. Fanfulla. 05/07/1918. Pág. 6. Existe uma segunda nota com o mesmo título no dia seguinte. Fanfulla. 06/07/1918. Pág. 5.

${ }^{475}$ Cose palestrine. Fanfulla. 26/02/1919. Pág. 5.

476 Riunione della comissione Pro-Stadium. Fanfulla. 04/04/1919. Pág. 5. A nota volta a insistir na questão da elevação das mensalidades e das taxas de adesão. Só descobrimos que uma das opções era a compra do Parque Antarctica por intermédio d'A Gazeta.

477 Palestra Itália. Fanfulla. 19/08/1919. Pág. 7. "Avrà luogo domani alle ore 16, nel campo nostro (Antarctica) um rigoroso allenamento fra la prima e seconda squadra di nuestra società."

${ }^{478}$ L’inaugurazione del nuovo ground palestrino. Fanfulla. 04/10/1919. Pág. 6.
} 
Naquela ocasião, o conselho administrativo do clube era formado por Menotti Falchi, dott. cav. Vito Celi, David Gliolitti, Giuseppe Venosa, Pasquale Barberia, Cláudio Bosisio, Alfonso Rocco, cav. Nicola Puglisi, cav. Luigi Favilla, Nicola Serricchio, Giuseppe Perrone, Carmine Pastore, Martino Frontini, Enrico Fontana, Alcardo Borin, Eutichiano Zerlini, ing. Alberto Sironi e Franco Tosi.

Em assembleia realizada em fevereiro de 1920, um novo conselho administrativo foi formado: Rodolfo Crespi (apelidado de o Barão da Greve, em 1917, pelos operários, ${ }^{479}$ Vito Celi, Francesco de Vivo, Aleardo Borin, Paolo Siciliano, Federico Sutti, Beniamino Grandi, Antonio Vaudagnotti, Adolfo Izzo, Egígio Pinotti Gamba, Nicola Puglisi, Nicola Serricchio, Américo Giorgetti, Luigi Favilla, Alcântara Pocci, Dante Isoldi e Ercole Russo. ${ }^{480}$ Nessa mesma ocasião, o conde Francisco Matarazzo foi eleito presidente honorário do clube, no lugar do filho Ermelino, que falecera em janeiro de 1920. Pela primeira vez, os nomes dos mais importantes industriais italianos de São Paulo apareciam no periódico relacionados com a direção do Palestra Itália.

Em maio de 1920, o Fanfulla publica carta enviada por Erminio Belli, primeiro secretário do clube, que informa que o campo do Palestra Itália no Parque Antarctica fora inaugurado em 27 de abril, sendo, desde então nomeado Palestra Itália, e que o clube pretendia adquirir todo o complexo do Parque Antarctica. ${ }^{481} \mathrm{Na}$ mesma nota, informa que Eduardo Matarazzo doara cinco mil tijolos para cercar a área palestrina. $\mathrm{Na}$ mesma semana, informa que o ground do Palestra Itália ficava anexo ao Parque Antarctica. ${ }^{482} \mathrm{E}$ que, ainda assim, uma nova sede social era alugada pelo clube na Rua São Bento, em junho. ${ }^{483}$ Segundo o Álbum do Jubileu de Ouro, a assembleia que autorizou a negociação com a Cia. Antarctica Paulista ocorreu em 23 de abril e a assinatura em cartório em 26 de abril. ${ }^{484}$

\footnotetext{
${ }^{479}$ LOPREATO, Christina da Silva Roquette. A semana trágica. A greve geral anarquista de 1917. Pág. 49.

${ }^{480}$ L'assemblea del Palestra Itália. Fanfulla. 12/02/1920. Pág. 6.

${ }^{481}$ Palestra Itália. Fanfulla. 11/05/1920. Pág. 5.

${ }^{482} \mathrm{Nel}$ ground del palestra Itália anesso al parque Antarctica avrà luogo quest'oggi un match di campionato che promette di riuseire interessante. Fanfulla. 16/05/1920. Pág. 5.

${ }^{483}$ Nel Palestra Itália. Fanfulla. 24/06/1920. Pág. 4.

484500 contos custou o Parque Antarctica. Sociedade Esportiva Palmeiras (1914 - 1964). Álbum Comemorativo Jubileu de Ouro. A Cia. Antarctica exigiu, em contrato, a exclusividade do fornecimento de bebidas aos frequentadores, a manutenção do acesso de um restaurante, que era por ela mantido, ao campo e o uso exclusivo dos espaços publicitários.
} 
A partida contra o Paulistano no Parque Antarctica, em 15 de agosto daquele ano, pelo Campeonato Paulista, recebeu um grande público, estimado pelo periódico em oitenta mil pessoas. ${ }^{485}$ E, só a partir daí, dos esforços para a compra do Parque Antarctica, as adesões dos italianos enriquecidos ou de classe média ao Palestra Itália se multiplicaram. ${ }^{486}$ Muitos dos chamados fundadores beneméritos do Álbum do Jubileu de Ouro contribuíram com dinheiro para a aquisição do Parque Antarctica ou para a construção do estádio a partir do final da década de 1920. Possivelmente, os Matarazzo foram os que mais contribuíram para a empreitada, mas a ideia de que, em 1921, o Conde Francisco Matarazzo ajudou o Palestra Itália a adquirir o Parque Antarctica precisa ser melhor discutida, já que alguns autores chegam a falar em doação do terreno ao Palestra Itália, ${ }^{487}$ quando o empresário pegou para si parte do terreno adquirido com seu dinheiro.

Em 1929, quando o Conde Eduardo Matarazzo, filho caçula do Conde Francisco Matarazzo, assumiu a presidência do clube, um novo projeto de estádio foi apresentado e levado adiante após a depredação de 1928. Como em 1931, a construção do estádio prejudicava a formação de um time competitivo e municiava a oposição, e, em depoimento À Gazeta Esportiva, o presidente fala sobre a eleição que se aproximava e das dificuldades em gerir o clube diante do desafio de construir um estádio. ${ }^{488}$ Em sua gestão, o Palestra Itália começa a publicar a revista Palestra Itália, que serviria de referencial para a memória palestrina.

Alfredo Salun afirma que, naquela ocasião, assim como ocorria no Paulistano, existiam duas correntes que disputavam o controle do clube: uma interessada na manutenção das atividades futebolísticas e inclinada a aceitar o profissionalismo; outra que defendia a extinção desses quadros esportivos por ser contra a profissionalização. ${ }^{489}$ Em sua pesquisa, o autor encontrou um fragmento de panfleto produzido pela oposição

\footnotetext{
485 Emozionante giornata sportiva. Il Palestra Itália pareggia col Paulistano per 1 a 1. Fanfulla. 16/08/1920. Pág. 3. O Jogo Palestra - Paulistano. O Estado de S. Paulo. 16/08/1920. Pág. 3. Cerca de 50 mil pessoas.

486 Colossale affluenza di soci al Palestra Itália. Fanfulla. 01/09/1920. Pág. 04. O jornal cita o nome de dezenas de novos sócios. Cabe destacar o grande número de membros da família Matarazzo que se associaram ao clube nesse contexto.

${ }^{487}$ COUTO, Ronaldo Costa. Op. Cit. Pág. 63. "Parte do terreno foi cedido ao antigo Palestra Itália depois Sociedade Esportiva Palmeiras -, de que Matarazzo foi benfeitor e presidente honorário."

${ }^{488}$ SALUN, A. O. Op. Cit. Págs. 93 e 94. A Gazeta, 22/12/1931.

${ }^{489}$ SALUN, A. O. Op. Cit. Pág. 96.
} 
à diretoria comandada por Eduardo Matarazzo, denunciando a família Matarazzo por utilizar o lençol freático existente no subsolo sem repassar qualquer benefício ao clube. ${ }^{490}$ Por ocasião das eleições, a oposição denunciava que os resultados estavam fraudados. ${ }^{491}$

A criação de uma revista palestrina, que tinha em Thomas Mazzoni um dos colaboradores, ajudou a consolidar o imaginário do clube relacionado à certa capacidade de unificar a comunidade ítalo-paulistana, sob as demandas de determinados grupos que controlavam a direção do clube e em detrimento de outros.

\subsection{Da Sociedade Esportiva Palestra Itália à Sociedade Esportiva Palmeiras.}

“Até hoje, o goleiro Oberdan se lembra das vaias do torcedor são-paulino quando o Palmeiras entrou em campo, com o capitão do exército Adalberto Mendes à frente, conduzindo a bandeira brasileira para que fosse reafirmado o sentimento patriótico dos jogadores. A rivalidade entre os dois clubes era tanta que fez surgir um boato de que o São Paulo - que, segundo Oberdan Catani, mandava na Federação -, se aproveitando da antipatia gerada pelo nome Palestra Itália, queria se apossar do parque Antarctica. Foi um tremendo disse-que-disse. Intrigas não faltavam."492

“(...) Então, nós passamos, depois disso, a nos chamar Sociedade Esportiva Palmeiras. Então, eles tentavam, eles queriam naturalmente, é evidente que queriam, porque eu participei, eu sou figura viva que presenciei e participei. Quantas vezes caminhões com gente do São Paulo apareciam por lá de noite, querendo se ismicuir nas coisas do Palmeiras e tomar o Parque Antarctica. Como eles não conseguiram êxito nessas tentativas, eles foram tomar a Associação Alemã de Esportes, tomaram, que é onde está a que foi chamada de Ilha da Madeira, Canindé. Que eles tomaram e eu não sei como eles venderam para a Portuguesa se aquilo não era deles. Então, não conseguiram tirar o Palmeiras, mas tiraram os alemães da Associação Alemã. A história é muito terrível. Eles foram muito causticantes, muito odiosos, rancorosos. E deixa a gente com resquício de prevenção. Porque eu sempre digo, eles seriam até capazes de praticar uma boa ação. Nunca vi tanto ódio.,"493

\footnotetext{
${ }^{490}$ SALUN, A. O. Op. Cit. Pág. 97.

${ }^{491}$ SALUN, A. O. Op. Cit. Pág. 95. A Gazeta 29/12/1931.

492 SANDER, Roberto. Anos 40. Viagem à década sem copa. Pág. 141.

493 NEGREIROS. P. A nação entra em campo. O futebol nos anos 30 e 40. Pág. 238. Depoimento de Paulo Schiesari ao autor.
} 
Ao estudar as maneiras de pensar e de viver da comunidade ítalo-paulista ou ítalo-paulistana, Mário Carelli chama a atenção para o caráter ambíguo das diversas sociedades italianas. ${ }^{494}$ Embora algumas se propusessem a defender a italianidade, rapidamente passaram a favorecer a aproximação com os demais paulistas. Se, dificilmente, os italianos se desligavam de seus preconceitos étnicos e suas relações com operários negros, mulatos, portugueses ou espanhóis fossem muitas vezes conflitivas, ${ }^{495}$ com o passar dos anos contribuíram para a extensão e diversificação da fisionomia da cidade, reforçando a classe média ${ }^{496}$ e criando uma das facetas da identidade paulistana do século XX.

A ideia de italianidade se fortaleceu no período entre guerras, em especial com a atuação dos empresários e comerciantes italianos ou seus descendentes. ${ }^{497}$ Naquele contexto, boa parte dos que advogavam a ideia estava no Brasil há muitos anos ou era brasileira. Além disso, as interpretações que falam em italianidade como fator de união dentro da comunidade italiana são deformadoras, ${ }^{498}$ pois, mesmo durante a Primeira Guerra, os antagonismos dentro da comunidade italiana sobre os sentimentos patrióticos foram muito fortes, mesmo que anarquistas e comunistas pacifistas formassem uma minoria. ${ }^{499}$ Ao mesmo tempo, o sentimento de orgulho nacional existente no seio da comunidade italiana reavivou desvios e exageros acerca do conceito de italianidade, que, a partir dos anos 1920, passou a ser vinculado, exclusivamente, ao fascismo. ${ }^{500}$

${ }^{494}$ CARELLI, M. Op. Cit. Pág. 56.

${ }^{495}$ CARELLI, M. Op. Cit. Pág. 67; MARTINS, José de Souza. Empresários e trabalhadores de origem italiana no desenvolvimento industrial brasileiro entre 1880 e 1914: o caso de São Paulo. Pág. 29.

496 CARELli, M. Op. Cit. Pág. 38; SANTOS, Viviane Teresinha dos. Os seguidores do Duce. Os italianos fascistas no Estado de São Paulo. Pág. 33. A autora apresenta um relato interessante acerca de um banquete realizado no Circolo Italiano, em abril de 1938, por militantes fascistas, que propunham a utilização de uma determinada instituição fascista para facilitar a penetração do fascio entre brasileiros, espanhóis e portugueses.

497 TRENTO, A. Do outro lado do Atlântico. Um século de imigração italiana no Brasil. Pág. 287. O autor define a ideia de italianidade como mito de italianidade, que foi amplamamente cultivado e adquiriu conotações políticas naquele contexto.

498 TRENTO, A. Do outro lado do Atlântico. Um século de imigração italiana no Brasil. Pág. 301.

499 TRENTO, A. Op. Cit. Págs. 196 e 197.

500 TREnTO, A. Op. Cit. Pág. 303. BERTONHA, J.F. Op. Cit. Págs. 25 e 26. O autor informa que a questão imigratória nunca foi vista de forma homogênea pelas classes dirigentes italianas. Dos debates desses grupos, surgiu um discurso nacionalista antes da Primeira Guerra Mundial que previa a incorporação dos emigrados à expansão imperialista italiana. Possivelmente, foi nesse contexto que o Consulado Italiano em São Paulo apoiou a farsa armada pela APEA com o Pro-Vercelli/Representação Oficial Italiana, em 1914. 
Os problemas das identidades dos imigrantes, ricos ou pobres, do norte ou do sul, italianos ou não, mantinham-se presentes de maneira intensa. No caso italiano, havia um problema maior: aqueles que aportaram no Brasil nas últimas décadas do século XIX e primeiras do século XX, muitas vezes, sequer se identificavam como italianos: eram calabreses, vênetos, baresis, de acordo com a região de origem. Quando a Itália foi feita, a imigração desses grupos foi uma consequência. Apenas pelo contato com brasileiros ou outros imigrantes, descobriam-se italianos. E, quanto mais permaneciam no Brasil, contraditoriamente, mais se distanciavam da Itália. ${ }^{501}$

Durante o período estudado, a política imigratória do governo italiano sempre se mostrou contrária à assimilação dos italianos pelas sociedades que os recebiam, ${ }^{502}$ pois os recursos remetidos pelos imigrantes à Itália eram fundamentais para a economia italiana $^{503}$ e estimularam um colonialismo peculiar, no qual os italianos habitantes de além-mar mantinham status habitualmente concedidos pelas metrópoles coloniais aos seus súditos colonizadores. ${ }^{504}$ Mas a assimilação desses imigrantes pela sociedade paulistana ocorreu. Das relações entre italianos e paulistanos, surgiram os ítalopaulistas, grupo social que foi capaz de alargar os limites da estreita consciência nativista pelo entrelaçamento de nacionalidades. ${ }^{505}$ Aos poucos, pelo contato com os paulistanos, distanciaram-se da Itália e criaram uma nova forma de ser paulistano.

A assimilação linguística do italiano à língua portuguesa costumava ocorrer já na primeira geração. ${ }^{506}$ Esse processo não se deu em uma via de mão única: os descendentes de italiano contribuíram para modificar algumas características do

${ }^{501}$ IANNI, C. Op. Cit. Págs. 113, 114 e $115 . \quad$ TRENTO, A. Op. Cit. Pág. 195. Documento consultado e citado pelo autor afirma que "tendo boa ou má sorte, nessas regiões, os italianos são gradativamente absorvidos pelo ambiente em que vivem, esquecendo facilmente sua língua, e são, por assim dizer, assimilados desde a primeira geração". BERTOLLA, C. Rapporto, in Emigrazione e Colonie, 1893. Pág. 136.

${ }^{502}$ IANNI, Constantino. Homens sem paz. Os conflitos e os bastidores da emigração italiana. Pág. 113.

${ }^{503}$ IANNI, C. Op. Cit. Pág. 18.

${ }^{504}$ IANNI, C. Op. Cit. Pág. 27. TRENTO, A. Op. Cit. Pág. 196. O código italiano definia como italianos, pelo jus sanguinis, aqueles que nasciam no Brasil e eram filhos de italianos.

${ }^{505}$ BELLUZZO, Ana Maria de Moraes. Voltolino e as raízes do modernismo. Pág. 135.

506 TRENTO, A. Op. Cit. No capítulo "Vida coletiva e assimilação", o autor apresenta uma série de situações em que a língua italiana foi corrompida pelo contato com a língua portuguesa, inclusive nos periódicos italianos produzidos por italianos erradicados no Brasil há muitos anos. Discordo de sua posição acerca da relativamente pacífica assimilação italiana à comunidade paulistana. $\mathrm{O}$ próprio autor relata episódios de violência contra os italianos na página 192. Na pesquisa encontramos relatos de brigas entre brasileiros e italianos, em 1914, por conta das partidas das equipes italianas naquela ocasião. 
linguajar paulistano e se identificavam com a sociedade brasileira na primeira geração nascida aqui. ${ }^{507}$

Dentro dessas discussões, alguns dados sobre o Palestra Itália chamam atenção. Na obra histórico-biográfica produzida por Leopoldo Santanna, apenas três jogadores do Palestra Itália, em 1918, eram italianos: Domenico Delascio, Luiz Olivieri e Oscar Frederici. Os demais, embora de ascendência italiana, já eram nascidos no Brasil. No contexto entre guerras, os italianos que viviam em São Paulo formavam um grupo envelhecido e em desaparecimento em números absolutos e, ainda mais, em termos relativos. ${ }^{508}$ Por ocasião do quarto aniversário do clube, em 1918, o hino palestrino lançado pelo Fanfulla estava em língua portuguesa. ${ }^{509}$ Segundo o Álbum do Jubileu de Ouro, as atas do clube já eram escritas em português por volta de $1921 .{ }^{510}$

E foi nesse momento que o mito da italianidade ganhou força, estimulado por interesses classistas dos industriais enriquecidos, dos interesses imperialistas do governo italiano liberal ou fascista, a partir de 1922, ou dos segmentos médios que começavam a se formar e que buscavam se distanciar dos operários, uma imensa maioria de ascendência italiana. ${ }^{511} \mathrm{E}$, entre os anos 1920 e 1940, este sentimento confundiu-se com o fascismo.

O surgimento do fascismo se deu dentro de um clima patriótico pós-Primeira Guerra Mundial. ${ }^{512}$ Sua difusão junto à comunidade italiana em São Paulo ocorreu dentro do projeto político imperialista e envolveu a diplomacia italiana por todo o período de governo fascista. ${ }^{513}$ As relações de parcela da comunidade italiana paulistana

${ }^{507}$ CARELLI, M. Op. Cit. Pág. 72.

${ }^{508}$ TREnTO, A. Op. Cit. Pág. 328; BERTONHA, J. F. Op. Cit. Pág. 195. Segundo o autor, não passavam de $0,6 \%$ da população brasileira, $5 \%$ da população paulistana e $2,5 \%$ da população paulista.

${ }^{509}$ Inno al Palestra. Fanfulla. 25/08/1918. O hino foi apresentado pelo periódico para que as pessoas que fossem participar das celebrações marcadas para o Teatro Avenida (que, segundo o periódico, ficava na Avenida São João) pudessem acompanhar a cantora portuguesa Elvira Martins. Al teatro avenida. Fanfulla. 26/08/1918.

510 A primeira diretoria. Sociedade Esportiva Palmeiras (1914 - 1964). Álbum Comemorativo Jubileu de Ouro.

511 BERTONHA, J. F. Op. Cit. Pág. 201. O autor cita entrevista realizada com D. Lélia Abramo em que esta afirma que muitos das novas gerações de italianos, à medida que enriqueciam, abandonavam a militância de esquerda que muitos dos seus pais haviam tido e caminhavam para posições mais conservadoras.

512 BERTONHA, J. F. Op. Cit. Pág. 41.

513 BERTONHA, J. F. Op. Cit. Pág. 38. Para um melhor entendimento acerca do tema, verificar a pesquisa completa. $\mathrm{O}$ autor informa e discute todas as estratégias adotadas pelo governo italiano para difundir o fascismo na comunidade ítalo-paulista e seus objetivos. 
com o fascismo eram por demais evidentes. Os condes Matarazzo e Crespi chegaram a doar dinheiro à Mussolini em diversas ocasiões, ${ }^{514}$ assim como o Partido Fascista e entidades representantes do fascismo atuavam abertamente para conquistar novos adeptos. Por boa parte das décadas de 1920 e 1930, o governo fascista italiano, pela criação de organizações fascistas no exterior, tenta ampliar o número de seguidores.

A adesão da comunidade ítalo-paulista ao fascismo não foi automática. Alguns poucos se colocaram abertamente contra. No geral, existia uma simpatia que era mediada pelo sentimento nacionalista - situação que gerava confusões, como a de identificar como italianos patriotas apenas os que se declaravam fascistas ou a de definir como fascista todo aquele que demonstrava qualquer sentimento de admiração pela Itália, mesmo que esse sentimento não tivesse qualquer vínculo com o fascismo, ${ }^{515}$ mas que, no entanto, não adquiria as dimensões que a elite ítalo-paulista e o consulado italiano queriam. ${ }^{516}$

Entretanto, entre os grupos enriquecidos e a classe média, a adesão foi intensa. Para os primeiros, era escolha ideológica lógica no contexto de grandes agitações do operariado. ${ }^{517}$ Para os últimos, algo necessário para obter reconhecimento social ${ }^{518} \mathrm{e}$ acesso aos bons empregos oferecidos pelos industriais ou pelo Consulado. Mesmo entre este último grupo, os entusiastas do fascismo eram irrisórios. ${ }^{519}$

Seria de estranhar se o Palestra Itália não fosse incorporado ao projeto político fascista, pois, mesmo nos EUA, local em que a atuação fascista foi mais branda, os clubes esportivos se converteram em espaços prioritários de propaganda para o fascismo. ${ }^{520}$ A elite dirigente não deixaria de vinculá-lo aos seus interesses ideológicos

\footnotetext{
514 COUTO, Ronaldo Costa. Op. Cit. Págs. 243 e 252. TRENTO, A. Op. Cit. Pág. 323. O autor chama atenção para a influência que os grupos abastados exerciam nos segmentos médios para que aderissem ao fascismo.

${ }^{515}$ BERTONHA, J. F. Op. Cit. Pág. 188.

${ }^{516}$ BERTONHA, J. F. Op. Cit. Págs. 125 e 126. As festas e cerimônias do fascio no Parque Antarctica atraíam menos gente do que era esperado pelos organizadores. Como exemplo, a visita do líder fascista Luigi Ferdazoni a São Paulo, em 1937, que realizou um comício no Palestra Itália, teve menos público do que o esperado pelos organizadores.

${ }^{517}$ BERTONHA, J. F. Op. Cit. Pág. 174. MARTINS, José de Souza. Op. Cit. Pág. 66. O autor apresenta o relato do Francisco Matarazzo acerca do tema: "Sou um grande admirador do Mussolini. Estou convencido do ardente patriotismo e da forte sinceridade que o animam. Quem conheceu a Itália dos primeiros tempos do após-guerra e a visita hoje não pode deixar de admirar este homem formidável."

${ }^{518}$ BERTONHA, J. F. Op. Cit. Pág. 181; SANTOS, V. T. Op. Cit. Pág. 32.

${ }^{519}$ BERTONHA, J. F. Op. Cit. Pág. 102.

${ }^{520}$ BERTONHA, J. F. Op. Cit. Pág. 40.
} 
mais amplos. E, no entanto, apenas após intensos dissídios internos, em 1925, o Palestra Itália foi controlado pelos fascistas. ${ }^{521}$

Desde aquela ocasião, muitos italianos erradicados no Brasil acreditavam que o vínculo de associações ítalo-brasileiras com o fascismo seria um erro que poderia trazer péssimas consequências para a comunidade no Brasil. ${ }^{522} \mathrm{E}$, de fato, a vigilância policial em cima dos imigrantes, o racismo, os critérios e métodos que estavam na moda na Europa foram adotados contra os membros da comunidade italiana, desde os anos $1930 .^{523}$ Membros do próprio governo fascista italiano reconheciam os exageros praticados em São Paulo.

"O estudo da essência doutrinária e da prática de governo do fascismo não interessa muito. São os pequenos episódios locais - do garoto que frequenta as escolas italianas com uniforme de balilla, do grito fascista levado ao estádio pelo time de futebol do Palestra Itália, do "Viva Roma" gritado por um nadador italiano que chega em primeiro numa competição organizada pelo Club Espéria que oferecem à imprensa o ensejo de assinalar o perigo fascista e de deflagrar campanhas e polêmicas." 524

A simpatia nutrida pelos setores enriquecidos pelo fascismo e suas relações com o consulado criavam a obrigatoriedade de todas as associações da comunidade na cidade controladas por esses grupos aderirem ao fascismo. Provavelmente, mais que ao fascismo, associavam-se ao consulado, sem o qual a sobrevivência era muito difícil. ${ }^{525}$ Aqueles que não aderiram sofreram pressões no trabalho, perderam seus empregos e

${ }^{521}$ BERTONHA, J. F. Op. Cit. Pág. 158. O autor chama a atenção para a existência de indícios claros da associação do clube com o Consulado no período entre guerras, contradizendo ARAÚJO, José Renato Campos de. Imigração e futebol. O caso Palestra Itália e SALUN, A. Palestra Itália e Corinthians. Quinta Coluna ou Tudo Buona Gente?

${ }^{522}$ IANNI, C. Op. Cit. Pág. 118; BERTONHA, J. F. Op. Cit. Pág. 333. O autor menciona o episódio em que o periódico Il Piccolo foi empastelado, em 25 de setembro de 1928, como reação aos discursos racistas e ofensivos produzidos e publicados naquele periódico por Luigi Freddi, um dos fascistas mais ativos da cidade. Naquela ocasião, diversas manifestações anti-italianas ocorreram na cidade.

${ }^{523}$ IANNI, C. Op. Cit. Pág. 119. O autor chama a atenção para o fato de que a imensa maioria dos atingidos pelas medidas do governo brasileiro eram imigrantes idosos que já estavam aculturados e identificados com a sociedade brasileira; TRENTO, A. Op. Cit. Pág. 296. O autor informa que muitas das medidas adotadas pelos governos brasileiros se deram como reação a provocações dos elementos fascistas da comunidade ítalo-paulista.

${ }^{524}$ TRENTO, A. Op. Cit. Pág. 320. Telegrama de 16 de maio de 1929 ao Ministero degli Affari Esteri. ACS, DGPS, Div. AA. GG. RR. J 5, envelope 264. O envelope é sobre Antonio Piccarolo. Citado pelo autor.

${ }^{525}$ TRENTO, A. Op. Cit. Pág. 331. 
passaram por dificuldades para encontrar novas colocações, pois quase todos os empresários italianos ou ítalo-paulistanos eram fascistas. ${ }^{526}$

O Palestra Itália, que, desde a compra do Parque Antarctica no final da década anterior, contava com a generosa contribuição da elite italiana de São Paulo, foi atrelado ao fascismo, pois seus principais patronos eram profundamente identificados com o regime. Em 1925, as facções dentro do clube que eram contra o envolvimento da equipe com o fascismo provocaram uma grande confusão por conta das comemorações do aniversário da marcha sobre Roma. ${ }^{527} \mathrm{E}$, ainda assim, o entusiasmo pelo fascismo não era demonstrado em toda e qualquer circunstância, mesmo na ocasião em que o estádio do Palestra Itália foi utilizado para um comício fascista, em agosto de $1937 .{ }^{528}$

Com as leis nacionalistas de 1938, o governo brasileiro demonstrou o desejo de liquidar com o sentimento de italianidade. ${ }^{529}$ Ainda em fevereiro daquele ano, quando o filho de Mussolini visitou o Brasil, foi recebido pela diretoria palestrina. ${ }^{530}$ Mas, a partir do decreto-lei n. ${ }^{\circ} 383$, de abril de 1938 , que proibiu a prática de atividades políticas por estrangeiros em território nacional, ${ }^{531}$ o incentivo ao comportamento nacionalista de defesa da brasilidade estimulou a animosidade contra os grupos estrangeiros. ${ }^{532}$ Para italianos, japoneses e alemães, a situação se agravou a partir de 28 de janeiro de 1942, quando o governo brasileiro rompeu relações diplomáticas com os países do Eixo, por conta do ingresso brasileiro na Segunda Guerra Mundial. ${ }^{533}$

Após o anúncio do rompimento, o governo brasileiro publicou, nos jornais, um comunicado no qual afirmava "que as sociedades que tenham sócios estrangeiros, brasileiros naturalizados ou brasileiros de ascendência estrangeira, serão fiscalizadas ou mesmo terão cassados os seus registros por esta Diretoria". ${ }^{534}$ O comunicado

\footnotetext{
526 TRENTO, A. Op. Cit. Págs. 360 e 361. Ainda sim, a adesão aos fasci não foi tão grande como o divulgado pelos fascistas. Pág. 312.

527 TRENTO, A. Op. Cit. 328.

${ }^{528}$ TRENTO, A. Op. Cit. Pág. 339. "Gli assenti”, in Giovinezza, 07/08/1937.

${ }^{529}$ SANTOS, Viviane Teresinha dos. Rivoluzionari in San Paolo. Pág. 19.

${ }^{530}$ Os ratos verdes e o Palestra. A Gazeta Esportiva. 14/02/1938. Pág. 3.

${ }^{531}$ SANTOS, Viviane Teresinha dos. Op. Cit. Pág. 85.

${ }^{532}$ SANTOS, Viviane Teresinha dos. Op. Cit. Págs. 25 e 88. A autora chama a atenção para os diversos estigmas existentes contra os italianos na sociedade paulistana naquele context, como o termo carcamano, que expressava uma imagem preconceituosa dos italianos em geral, estigmatizados como cidadãos ignorantes, sem polidez e desonestos.

${ }^{53}$ SANTOS, Viviane Teresinha dos. Op. Cit. Pág. 90.

${ }^{534}$ Aos clubes esportivos. A Gazeta. 03/02/1942. Pág. 10.
} 
informava ainda que os clubes que não se nacionalizassem nos termos da lei seriam dirigidos, fiscalizados ou perderiam seus registros.

O E. C. Germânia sofreu a intervenção naquela mesma semana: sua direção foi destituída, novos sócios brasileiros natos foram convocados para reorganizar as atividades do clube e, em abril daquele ano, o clube adotou o nome "nacionalizado" de Esporte Clube Pinheiros. ${ }^{535}$

Diante do envolvimento da agremiação palestrina com a italianidade estimulada pelo consulado italiano, com a simpatia nutrida pelo fascismo por quase todos os dirigentes e com o envolvimento com organizações fascistas de São Paulo, o clube ficou em situação muito difícil. Em março de 1942, A Gazeta publica o comunicado enviado pela diretoria palestrina que anuncia a mudança de nome do clube de Palestra Itália para Palestra de São Paulo. ${ }^{536}$ Em junho daquele ano, o decreto n. ${ }^{\circ} 12.758$ determinava que "os súditos dos países com os quais o Brasil está em guerra não poderão tomar parte em qualquer competição, bem como continuar como sócios dos clubes esportivos; nenhum técnico desportivo dos referidos países poderá continuar a exercer sua profissão; as federações deverão providenciar a respeito, com urgência, e zelar pelo cumprimento destas determinações."

A diretoria palestrina naquela ocasião era constituída por Ítalo Adami presidente, brasileiro e industrial ${ }^{538}$, Hygino Pellegrini - vice-presidente, brasileiro e comerciante, João Giannini - segundo vice, brasileiro e industrial, Savério Mandetta terceiro vice, brasileiros e funcionário federal, Paschoal Giuliano - secretário-geral, brasileiro e advogado, Edmundo Scala - primeiro secretário, brasileiro e médico, Alduino Biagioni - segundo secretário, italiano, mas brasileiro por declaração e funcionário público do Estado de São Paulo, Leonardo Lotufo - primeiro tesoureiro, brasileiro e industrial, Roberto Lagório - segundo tesoureiro, italiano e comerciante, Attilio Ricotti - economista, italiano e industrial e Caetano Marengo - diretor-geral, italiano e comerciante. ${ }^{539}$ Os italianos que participavam da direção do clube foram afastados de imediato.

\footnotetext{
${ }^{535}$ Um brinde do E. C. Pinheiros à crônica esportiva da cidade. A Gazeta. 30/04/1942. Pág. 9.

${ }^{536}$ O Palestra passou a denominar-se Palestra de São Paulo. A Gazeta. 14/03/1942. Pág. 8.

${ }^{537}$ Os subditos do eixo. A Gazeta Esportiva. 26/10/1942. Pág. 2.

538 FIGUEIREDO, A. Op. Cit. Pág. 91. Ítalo Adami, àquela época, possuía vasta experiência como dirigente esportivo, pois havia presidido o time do Minas Gerais entre 1916 e 1918.

${ }^{539}$ SALUN, A. O. Op. Cit. Pág. 209.
} 
Em agosto, A Gazeta Esportiva publica o artigo Guerra de nervos, a partir de uma carta assinada por Leonardo Lotufo, dirigente palestrino. Era uma resposta a uma acusação de suborno contra os dirigentes palestrinos. Os acusadores não são mencionados no texto, mas, em determinado momento, o missivista deixa escapar o que acontecia naquele exato momento entre os dirigentes palestrinos e os dirigentes de outras equipes que disputavam o Campeonato de 1942. Vejamos:

"No entanto, não quero deixar de dar uma opinião, toda pessoal, sobre a origem e a intenção dessa propalada tentativa de suborno. Trata-se, sem dúvida, - por mais que perca em considerações não descubro os motivos - de uma autêntica guerra de nervos, que meia dúzia de desclassificados está promovendo, utilizando-se de elementos que se prestam para tal fim, com o intuito de lançar o pânico no seio da organização do Palestra de São Paulo, na esperança de obterem o descontrole dos componentes da sua direção, desorganizando a poderosa máquina esportiva alviverde e visando, assim, - já que pelos meios honrados vai se tornando sempre mais difícil - entravar os passos seguros do glorioso Palestra de São Paulo, nesta sua marcha brilhante, em busca do almejado título máximo deste movimentado e belíssimo campeonato de 1942."

Como o Campeonato Paulista de 1942 alcançara êxito de público e mostrava-se muito disputado entre São Paulo e Palestra Itália, os boatos entre torcedores e dirigentes começaram a circular pela cidade como estratégia para desequilibrar os adversários. Diversos boatos circularam naquela ocasião, um dos quais envolvia o Santos Futebol Clube e o Palestra Itália em um caso de suborno. Mas, em especial, a torcida tricolor aproveitava o clima gerado pela Segunda Guerra Mundial e o ingresso do Brasil no conflito contra os países do Eixo para tentar desestabilizar os concorrentes diretos pela disputa do título paulista daquele ano com insultos e ofensas xenofóbicas contra italianos. Em artigo assinado por José de Moura n'A Gazeta, conseguimos compreender a situação:

"Os homens olvidam depressa o motor de seus deveres - o dever que cada um tem para consigo próprio. Por certo, Oscar Wilde não pensara no futebol nem nos venenos do nosso mundo futebolístico quando citou essa verdade indesmentível... E porque os homens esquecem muito cedo ou mesmo a todo instante de seus próprios deveres é que assistimos estarrecidos, nestes últimos dias, a uma borrasca tremenda. O temporal das paixões clubísticas desabou precisamente no momento em que tudo era calmaria e bonança. Jamais tivemos época mais feliz e

\footnotetext{
${ }^{540}$ Guerra de nervos... A Gazeta Esportiva. 31/08/1942. Pág. 2.
} 
tranquila em nosso futebol. 1942 parecia o ano da glorificação do profissionalismo em São Paulo. Todos os recordes foram batidos. Rendas, disciplina, goals e, até acidentes... Apesar de tudo, 1942 era, até então, o marco de uma era vitoriosa do futebol, era de paz, de trabalho e justiça. No entanto, subitamente, sobreveio o que ninguém esperava. Os artistas do veneno agiram a rédea solta, atirando o nome do futebol à sua amargura, glosando verdades e inverdades que bem poderiam ser estudadas à luz discreta das secretarias ou nas próprias salas das autoridades policiais com o impenetrável sigilo que sempre ajuda o pessoal da nossa Scotland Yard a desvendar os maiores mistérios."541

$\mathrm{O}$ artigo foi escrito na véspera do jogo que decidiria o Campeonato Paulista daquele ano, marcado para 20 de setembro, e atesta a existência de boatos. Mas questiona as origens desses boatos, pois, segundo o autor, esses não tinham fundamentos e eram obra da oposição.

"Devemos, ainda, assinalar, aqui, outra grande injustiça que corre mundo pela boca dos palpiteiros e dos inimigos do tricolor atribuindo ao clube mais querido da cidade a onda que se levantou contra o alvi-verde do Parque Antarctica. Para os apologistas da confusão e das mentiras, o S. Paulo pretendia estabelecer o desânimo nas hostes esmeraldinas e ganhar assim o campeonato! Não há mentira maior! Em primeiro lugar, o S. Paulo F. C. não sabe o que seja lançar mãos de recursos estranhos ou de golpes baixos para ganhar em campo quando é certo que grande, muito grande, ele tem sido na vitória ou na derrota... O jogo do dia 20 será decidido apenas no gramado e tudo que se disser fora daí é - intriga da oposição." 542

Uma semana antes, o clima azedara entre os integrantes das equipes juvenis de Palestra Itália e São Paulo, o que se converteu em uma guerra campal no Parque Antarctica. ${ }^{543} \mathrm{O}$ Palestra Itália chegou a receber a visita do presidente da CBD, Luiz Aranha, dois dias depois. No meio da boataria, a adesão do filho de Getúlio Vargas ao São Paulo F. C., ${ }^{544}$ xenofobia contra os italianos e seus descendentes, briga entre torcedores e dirigentes palestrinos e são-paulinos, tudo acontecia ao mesmo tempo. A direção palestrina organizou uma grande festa em homenagem ao Dia da Independência do Brasil, prometeu doar a renda gerada pela partida contra o São Paulo F. C. para as

\footnotetext{
${ }^{541}$ Intrigas da oposição. A Gazeta. 18/09/1942. Pág. 8.

542 Idem, Ibidem.

${ }^{543}$ Semeando ventos. A Gazeta. 04/09/1942. Pág. 8.

${ }^{544}$ O Dr. Getúlio Vargas Filho. A Gazeta. 01/09/1942. Pág. 8.
} 
famílias das vítimas dos navios brasileiros atacados por submarinos alemães ${ }^{545}$ e achou por bem alterar o nome do clube de Sociedade Esportiva Palestra de São Paulo para Sociedade Esportiva Palmeiras.

Em 14 de setembro de 1942, a diretoria palestrina decidia pela adoção do novo nome e enviava o ofício para os periódicos com os seguintes termos:

"Na reunião realizada ontem, sob convocação de seu presidente, a diretoria da Sociedade Esportiva Palestra de São Paulo resolveu, por unanimidade de votos, mudar a sua denominação, sendo escolhida a de Sociedade Esportiva Palmeiras, resolução e escolha essas, feitas ad-referendun do Conselho Deliberativo." 546

Alfredo Salun afirma não ter encontrado qualquer referência ao envolvimento do clube com entidades fascistas. ${ }^{547}$ Os testemunhos mostram outra situação. O clube esteve vinculado ao Consulado Italiano e ao empresariado italiano que simpatizava com o fascismo por toda a década de 1930, inclusive com a realização de comícios fascistas no Parque Antarctica. Além disso, é necessário mencionar que o prontuário do DEOPS sobre o Palestra Itália aponta que todos os dirigentes palestrinos eram filiados diretamente ao Partido Fascista de São Paulo ou a entidades que a ele se filiavam.

Se, de fato, os boatos existiram, os dirigentes palestrinos tinham motivos para temer a desapropriação, o fechamento ou a intervenção do clube por parte do governo federal, já que o confisco de bens de italianos, japoneses ou alemães fora autorizado pelo decreto-lei 3.911, de 9 de dezembro de 1941, aperfeiçoado pelo 4.166, de 11 de março de 1942 e regulamentado pela portaria 5.409, de 28 de abril de $1942 .{ }^{548}$ Descobrir qual a origem dos boatos não foi possível nesta pesquisa.

A nacionalização do Palestra Itália, alguns dias antes da partida decisiva contra o São Paulo, causou estranheza. Em artigo sem assinatura, A Gazeta questiona a medida. "Si o nome Palestra não mais se justifica para um clube de futebol brasileiro, igualmente não se justificam os nomes do Espanha, Juventus, Portuguesa e,

\footnotetext{
${ }^{545}$ Medida plausível. A Gazeta. 17/09/1942. Pág. 8.

${ }^{546}$ Sociedade Esportiva Palmeiras. A Gazeta. 15/09/1942. Pág. 8.

${ }^{547}$ SALUN, A. O. Op. Cit. Pág. 235.

${ }^{548}$ TRENTO, A. Op. Cit. Pág. 397. O autor informa que o artigo 1. o do decreto-lei 4.166 dizia: “Os bens e direitos dos súditos alemães, japoneses e italianos, pessoas físicas ou jurídicas, respondem pelo prejuízo, que, para os bens e direitos do Estado brasileiro, e para a vida, os bens e direitos das pessoas físicas ou jurídicas brasileiras, domiciliadas ou residentes no Brasil, resultaram ou resultarem de atos de agressão praticados pela Alemanha, pelo Japão ou pela Itália."
} 
principalmente, o de Espéria, caracteristicamente italiano. ${ }^{, 549}$ O São Paulo, até aquele momento, não conquistara nenhum título, investira muito dinheiro na formação da equipe, inclusive com a contratação de Leônidas, e seu favoritismo ao longo do ano fora superado pela equipe palestrina. Não seria de todo impossível que os boatos surgissem para criar um ambiente hostil contra os jogadores palestrinos, algo que, segundo o depoimento de Oberdan, realmente aconteceu quando a equipe ingressou no gramado do Pacaembu em 20 de setembro de 1942.

Sobre o depoimento de Paulo Schiesari recolhido por Negreiros, porém, identificamos que não procede a história que, naquele contexto, o São Paulo F. C. quisesse tomar o Parque Antarctica, pois a equipe tricolor já adquirira a própria sede no Canindé no início daquele ano. ${ }^{550}$

${ }^{549}$ Medida plausível. A Gazeta. 17/09/1942. Pág. 8.

${ }^{550}$ Em plena atividade a praça de esportes do São Paulo F. C. A Gazeta Esportiva. 06/04/1942. Pág. 14. 


\section{Sport Club Corinthians Paulista. O único time das massas?}

\subsection{A abertura do Corinthians à comunidade negra de São Paulo.}

"Não tinha preto naquele tempo no Palestra. Os torcedores eram 90\% italianos ou filhos de italianos. As brigas eram até mais brutas do que hoje. Me lembro de uma passagem do Neco, um dos maiores jogadores do Corinthians. Uma vez ele tirou o cinto e correu atrás do juiz batendo nele o tempo todo. Naquele tempo o Paulistano era o clube da elite. Mas as torcidas maiores eram do Corinthians e do Palestra. No Corinthians, estava a massa: os pretos e os espanhóis." ${ }^{, 51}$

Mas nessas tantas vitórias, algumas sensacionais / A gente esquece de tudo, não desanima jamais / Ai, Corinthians, cachaça do torcedor / colorido em preto e branco / Sem preconceito de cor. ${ }^{552}$

O imaginário sobre a equipe corintiana consolidado na sociedade paulistana, paulista e brasileira fala de uma equipe popular formada por negros, operários, imigrantes pobres etc. Segundo Florenzano, ${ }^{553}$ poderíamos pensar que, a partir de um determinado período, meados dos anos 1930, os jogos entre Corinthians e Palestra Itália/Palmeiras adquiriram um significado simbólico de uma disputa entre negros/corintianos e brancos/palestrinos.

No entanto, em sua origem, e durante muitos anos, o Corinthians não contou com jogadores negros, que só ocorreru após quase dez anos de existência do clube. Nessa pesquisa, descobrimos que, nas primeiras décadas do século XX, os jogadores negros de São Paulo se organizavam em equipes próprias, como o Diamantino F.C., o Perdizes F.C., o São Paulo F.C. e o Aliança F.C. ${ }^{554}$ A presença desses jogadores em

\footnotetext{
${ }^{551}$ BOSI, E. Memória e sociedade. Lembranças de velhos. Págs. 138 e 139. Depoimento do Sr. Amadeu Bovi.

552 Trecho da música Meus vinte anos, composta por Paulinho Nogueira em 1967. XAVIER, Beto. Futebol no país da música. Pág. 108.

${ }^{553}$ FLORENZANO, J.P. Op. Cit. Págs. 147 e 148.

554 Uma visita aos quadros de cor. Os quadros actuaes e antigos constituídos exclusivamente por jogadores pretos - A curiosa fundação do E.C. Piracicabano. A Gazeta Esportiva. 22/06/1930. Pág. 8. Uma pesquisa posterior e mais aprofundada poderá apontar o que aconteceu com essas equipes.
} 
equipes fundadas pelos filhos de imigrantes não ocorria pelo simples motivo do racismo.

Alguns autores, como Mário Carelli, ${ }^{55}$ apontam o aparecimento de certa hostilidade na cidade de São Paulo entre os descendentes de imigrantes e os descendentes de escravos desde a deflagração da Primeira Guerra.

As fontes pesquisadas indicam que o convívio entre as diversas comunidades na cidade de São Paulo não era fácil. Não era apenas luta de classes. Conflitos de toda ordem marcaram o período estudado, com racismo e xenofobia entre os próprios trabalhadores pobres da cidade, o que ocorria de todos os lados: dos imigrantes e seus descendentes contra os nacionais mestiços, negros ou caboclos; ou o inverso: a perseguição contra imigrantes também era recorrente. Ao pesquisarmos o Palestra Itália, percebemos que a própria comunidade ítalo-paulista foi vítima de intolerância, inclusive nos campos de futebol.

Anatol Rosenfeld, em trabalho que discute a questão do negro na sociedade brasileira no período abarcado por esta pesquisa, cita um episódio que ilustra o que comentamos:

"O caso de um outro milionário que procurava um motorista negro mostra que frequentemente ocorrem situações típicas de preconceito de cor, no qual a classe não tem papel significativo: os três empregados domésticos brancos disseram ao patrão que iriam embora se admitisse o motorista negro. Quando, apesar disso, ele o admitiu, eles não cumpriram a ameaça, mas exigiram que o negro fizesse suas refeições sozinho." 556

As evidências apontam para problema semelhante nos campos de futebol de São Paulo: brancos com suas equipes e ligas de um lado, negros com suas equipes e ligas do outro.

Desde o advento do fascismo, o desenvolvimento de um sentimento de xenofobia de grande parte da comunidade ítalo-paulista se intensificou. Esse fenômeno era plenamente visível no Palestra Itália, que só contratou jogadores negros a partir da década de 1940, e estava presente nas demais equipes de ascendência italiana e em

Aparentemente, com a incorporação dos atletas negros nas equipes da Liga, esses times perderam expressão e desapareceram.

${ }^{555}$ CARELLI, M. Op. Cit. Pág. 72.

${ }^{556}$ ROSENFELD, Anatol. Negro, macumba e futebol. Pág. 33. 
outros espaços sociais e culturais da comunidade. O exemplo de outubro de 1928, quando $O$ Combate publica a tradução de um artigo assinado por um dos principais nomes do movimento fascista em São Paulo, Osvaldo Brancaleoni, ilustra o problema. Naquela ocasião, os ânimos se acirraram contra a comunidade ítalo-paulistana e a sede do Fanfulla teve que ser protegida pela polícia. A publicação em questão afirma que

"Moças tipicamente brasileiras, isto é, de estatura mediana, formas volumosas e provocantes, tez escura, embelezadas até o ridículo, como, aliás, é o uso de todas as mulheres daqui, com que já nos habituamos. Belas e robustas mulheres que contrastam com os homens, em geral mirrados e sofridos. As moças rebolavam descaradamente e, então, senti, de modo mais terrível e real, a verdade que caracteriza o Brasil: as frutas não têm o sabor, o céu não tem a cor, as mulheres não tem pudor." 557

$O$ Combate informa que, em um jogo entre os times do Palestra Itália e do Corinthians, os palestrinos fizeram a saudação fascista para o cônsul Mazzolini, um dos grandes propagadores do fascismo em São Paulo. ${ }^{558} \mathrm{E}$ as ofensas se avolumaram por toda a década de 1930, de lado a lado, até o ingresso do Brasil na 2. ${ }^{a}$ Guerra Mundial, quando a comunidade ítalo-paulista ficou em uma situação muito delicada.

Dentro das discussões, um dado que chamou a atenção foi a realização, por toda a década de 1930 e parte da década de1940, do jogo Brancos X Negros. Quer por ocasião do dia 13 de maio ou para arrecadação de fundos para campanhas beneficentes, a partida mobilizava a população e transformou-se numa partida clássica do futebol paulistano. ${ }^{559}$ Nessas ocasiões, os melhores jogadores negros e brancos eram convocados para a formação dos selecionados branco e negro. Em 1931, a seleção negra de São Paulo chegou a disputar um amistoso internacional contra Ferencváros. ${ }^{560}$ Todos os grandes jogadores atuavam nessas ocasiões, fosse pela equipe negra ou pela equipe branca.

\footnotetext{
${ }^{557}$ TRENTO, A. Op. Cit. Pág. 336.

${ }^{558}$ BERTONHA, J. F. Op. Cit. Pág. 158. Ver "Eia Eia Alalá” (In): O Combate, 24/09/1928.

${ }^{559}$ Brancos X Pretos. O jogo nocturno de 13 de maio. A Gazeta Esportiva. Pág. 13. 13/05/1931. O festival de hoje, à noite, na Floresta, em benefício de Tatú. A Gazeta Esportiva. 08/10/1931. Pág. 12. Brancos X Pretos. Os brancos venceram por 5 a 3. A Gazeta Esportiva. 11/04/1932. Pág. 7. Brancos e pretos no clássico cotejo. A Gazeta Esportiva. 20/05/1940. Pág. 3.

${ }^{560}$ A selecção preta fará hoje sua estréa internacional, enfrentando o Ferencváros. A Gazeta Esportiva. 06/07/1931. Pág. 3.
} 
A equipe do Corinthians não passou incólume às questões raciais geradas pelo convívio entre negros e brancos em nossa sociedade, ainda mais se tratando de um clube fundado por imigrantes ou filhos desses. E não foi um problema exclusivo do Corinthians. Segundo Mazzoni, a equipe corintiana utilizou-se de diversos jogadores que vieram de outra equipe varzeana do Bom Retiro: a A. A. Botafogo. Durante alguns anos, as equipes apresentavam escalações próximas, exceto por Fabrinni, goleiro do Palestra Itália, Palamone, zagueiro do Mackenzie e David. Este último era considerado um dos grandes meio-campistas paulistanos da década de 1910 e, segundo a versão de Mazzoni, por ser negro, não era escalado no Corinthians porque os dirigentes tinham medo que a LPF não o aceitasse. ${ }^{561}$ Celso Unzelte alega que a inscrição do jogador foi tentada pelo clube, mas negada pela LPF. ${ }^{562}$

Na mesma nota, que, embora também falasse de David, era dedicada ao jogador Bingo, e Unzelte sugere que Asdrúbal Cunha, o Bingo, teria sido o primeiro jogador negro a vestir a camisa do Corinthians, algo que ocorreu apenas em 1919. O autor lembra, no entanto, que suas atuações destacadas criaram animosidades com Neco e inviabilizaram sua permanência no Corinthians. ${ }^{563}$ A história permanece obscura e não conseguimos elementos para esclarecê-la. Além da Liga, será que os próprios jogadores corintianos não restringiam o ingresso de atletas negros?

Depois desse episódio, apenas em 1921, Altino Marcondes, o Tatu, jogou pelo Corinthians. Anatol Rosenfeld escreve que, no Brasil, quem escapa de negro, branco é. E citava a observação feita por um viajante europeu do século XIX que diz que "aqui todas as pessoas, principalmente as pessoas livres, são brancas desde que não sejam pretas; frequentemente uma pessoa é oficialmente branca, mas, de acordo com a natureza, ela é quase negra. "564 O mesmo ocorria com Tatu, no Corinthians. Definir se Altino Marcondes era negro é por si só um problema sério. Para muitos, não era negro, talvez moreno, talvez mulato, mestiço... O fato é que, por toda a década de 1920, Tatu foi o único jogador não branco a atuar pela equipe corintiana.

\footnotetext{
561 MAZZONI, Thomaz. Espírito Varzeano. Amor corinthiano. (In): Corinthians. Campeão dos centenários. Pág. 52. Naquela ocasião, o Corinthians foi convidado pela APEA para trocar de liga e disputou e venceu amistosos contra todos os clubes da APEA, exceto o Paulistano, que recusou disputar. ${ }^{562}$ UNZELTE, C. Almanaque do Timão. Pág. 641. Provavelmente, o autor se baseia em outra obra de MAZZONI, T. História do futebol no Brasil. Pág. 119, que defende a mesma tese.

${ }^{563}$ UNZELTE, C. Op. Cit. Pág. 641.

${ }^{564}$ ROSENFELD, A. Op. Cit. Pág. 25.
} 
O depoimento de Francisco Rebolo sobre Tatu e o Corinthians da década de 1920 é esclarecedor em diversos aspectos:

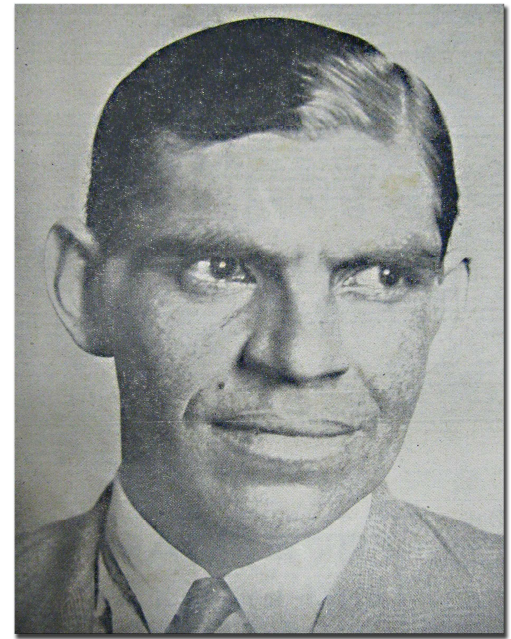

9. Altino Arantes, o Tatu, alguns meses antes de morrer.
"Um absurdo, mas existia mesmo essa interdição. Os times da elite não admitiam a entrada de jogadores negros. No meu tempo de jogador, não havia negros em nenhum time. Acabou minha carreira e posso assegurar que não joguei com preto e nem contra pretos nos jogos da liga; eu só tinha colegas negros na várzea... Eu me recordo de que no Corinthians surgiu um mulato chamado Tatu, que jogava muita bola, era um craque. Certa vez, num jogo entre Corinthians e Paulistano, o Tatu marcou o gol da vitória. A cidade ficou tomada, com gente fazendo discurso, já foi uma vitória do povão." 565

O primeiro dado possível de ser extraído do depoimento de Rebolo é que o processo racista não era exclusivo do Corinthians ou do Palestra Itália; os jogadores negros apenas atuavam pelos times da várzea porque as ligas interditavam suas participações nos jogos das principais equipes. O que não significa que não atuassem ou não gostassem de futebol desde os primeiros anos do século XX. O segundo dado é que a atuação de um mulato como Tatu chamava a atenção e repercutia entre os grupos populares da cidade, entre os membros das comunidades negras. É importante ressaltar que a atuação de Tatu era marcante não apenas por seu talento, que, entretanto, nunca foi comparado ao de um Fried, por exemplo, mas justamente pela raridade de encontrar um mulato nos campos da APEA.

Nesses primeiros anos de existência do Corinthians, seus jogadores eram, quase na totalidade, de ascendência italiana, alguns de espanhola e poucos de portuguesa. Os retratos expostos no Memorial Corintiano não deixam dúvidas. Nas duas primeiras décadas de existência, poucos negros atuaram pelo Corinthians. E, por toda a década de 1920, diversos jogadores da comunidade ítalo-paulista preferiram atuar pelo Corinthians e não pelo Palestra Itália, tanto que, quando a equipe da Lázio passou por São Paulo e

565 GONÇALVES, Antonio. A imagem da capa. (In): FILHO, Mário. O negro no futebol brasileiro. Fascículo sem numeração da página. 
recrutou jogadores da comunidade ítalo-paulistana, jogadores que ficaram conhecidos como oriundi, metade deles atuava pelo Corinthians e a outra metade pelo Palestra Itália.

Alguns dos jogadores que partiram para a Itália alcançaram grande êxito nos gramados e chegariam a participar da Seleção Italiana campeã mundial de 1934, caso de Filó. ${ }^{566}$ Só retornaram ao futebol brasileiro na segunda metade da década de 1930, muitos como veteranos, com a aproximação da $2 .^{a}$ Guerra Mundial e a ameaça de serem convocados para o exército fascista. Ao término da década, já aposentados como jogadores, destacar-se-iam como treinadores de futebol das três principais equipes de São Paulo.

E, assim, a partir dos anos 1930, como aponta Florenzano, a equipe corintiana passou a contar com jogadores negros em quantidade. Talvez o primeiro grande ídolo negro corintiano no contexto tenha sido o atacante Teleco, contratado entre 1934 e 1935. Outros se seguiram como Servílio e Baltazar. Mas, em hipótese alguma, podemos afirmar que o ingresso desses jogadores representou o fim dos preconceitos de cor, como sugere a música de Paulinho Nogueira.

$\mathrm{Na}$ história corintiana, nenhum negro assumiu a presidência do clube ou postos diretivos de relevância, ou dirigiu a equipe como treinador. Na prática, esses jogadores ingressavam no clube como funcionários do clube, quase como operários da bola. E alguns deles ganharam notoriedade e bons salários, mas não significava que tivessem qualquer possibilidade de ascender às estruturas administrativas do clube ou ser admitidos como associados votantes. O próprio Teleco, que morreu em 2000, foi funcionário do clube, e o máximo que ascendeu na hierarquia do clube foi ser um dos responsáveis pela manutenção da sala de troféus.

Podemos afirmar que, apenas a partir do êxodo de jogadores da comunidade ítalopaulista, com o advento da profissionalização na Itália e países do Rio da Prata, o Corinthians se abriu aos jogadores negros, quando os recrutou para recompor a equipe entre os primeiros anos da década de 1930. Naquela ocasião, o Corinthians possuía a melhor equipe de futebol da cidade formada por descendentes de italianos, e quase a metade de seus jogadores partiu para atuar pela equipe da Lazio de Roma ${ }^{567}$.

\footnotetext{
${ }^{566}$ Filó na selecção italiana. A Gazeta Esportiva. 15/01/1934. Pág. 13.

${ }^{567} \mathrm{Na}$ Itália. A Gazeta Esportiva. 07/09/1931. Pág. 7
} 
Por ocasião da debandada, ocorrida em 1931, A Gazeta Esportiva publica um artigo em que se discute se o Corinthians teria forças para reformular a equipe.

"O quadro decepcionou nestes dois últimos jogos, mas não se deve esquecer que depois de ver esphacelado o conjunto; depois de tantos percalços, e mais apresentando-se o onze radicalmente removido, não se podia desejar milagres do Corinthians. Fomos vencidos, paciência. O Corinthians venceu três annos consecutivos, e é natural que, como no passado, sobrevenha um período de incerteza, de baixa dos jogadores. Isso dos que ficaram. Os outros deixaram a turma por motivos vários, dahi ella ter soffrido as consequências. Quatro rumaram para o estrangeiro, três foram afastados por doença ou por declínio de forma: Munhoz, Gamba e Tuffy, estão neste caso. Sete jogadores, pois, estão afastados da turma... A direção esportiva do clube tem empregado todos os esforços para sanar a lacuna, experimentando novos jogadores, intensificando os treinos, fazendo várias modificações, nas várias linhas." 568

Desde setembro de 1931, o Corinthians buscou reforços entre alguns jogadores negros. O primeiro foi o goleiro João Henrique de Oliveira, conhecido como Onça. Em 1932, o zagueiro Euclides Barbosa, conhecido como Jaú assumiu uma vaga na zaga. No ano seguinte, a equipe corintiana era formada por Cruz, Bahianinho, Brito e Boulanger, além de Jaú e Onça. ${ }^{569}$ Em 1934, Uriel Fernandes, o Teleco, chegou para assumir uma vaga no ataque. Em 1935, chegou Brandão, oriundo da Portuguesa. Servílio chegou em 1938 e, ao lado de Teleco, formou uma grande dupla de ataque, responsável pelo último tricampeonato conquistado pela equipe. ${ }^{570}$

As trajetórias de alguns desses jogadores pelo Corinthians não foram fáceis. $\mathrm{O}$ zagueiro Jaú, que rapidamente assumiu o papel de capitão da equipe, nunca se livrou da pecha de vendido por conta de um episódio em que um dirigente do Palestra Itália teria tentado suborná-lo. ${ }^{571}$ Transferiu-se para o futebol do Rio de Janeiro, em 1937, dentro

\footnotetext{
${ }^{568}$ O Corinthians e o seu quadro actual. A Gazeta Esportiva. 04/10/1931. Pág. 03.

${ }^{569}$ Nos últimos quinze minutos de uma lucta falha, o Corinthians com um quadro novo que não convence, assignala o tento da Victória sobre o São Bento. A Gazeta Esportiva. 15/05/1933. Pág. 5.

${ }^{570}$ UNZELTE, C. Almanaque do Timão. Págs. 715 e 719. O Corinthians foi tricampeão paulista em três ocasiões: 1922,1923 e 1924; 1928, 1929 e 1930; 1937, 1938 e 1939. A dupla conquistou os campeonatos de 1938,1939 e 1941.

${ }^{571}$ UNZELTE, C. Op. Cit. Pág. 675. O dirigente foi absolvido do caso, mas o jogador nunca foi perdoado pela diretoria corintiana.
} 
do contexto de profissionalização, enfrentando grande hostilidade da diretoria corintiana por esse ato. ${ }^{572}$

E nesse contexto, a presença de negros nos quadros e arquibancadas das outras equipes foi apagada ou minimizada, mesmo que as fotografias dos anos 1930 demostrem que todas as equipes do futebol de São Paulo, exceto o Palestra Itália, possuíam torcedores e jogadores negros em igual proporção. E, no Palmeiras, a partir da segunda metade do século XX, sua torcida passou pelo mesmo processo de mestiçagem que marcava as torcidas de outras equipes e ficou formada não apenas por descendentes de italianos, mas também por negros, mestiços, nordestinos, descendentes de japoneses, entre outros grupos étnicos da cidade. $\mathrm{E}$ os tratamentos e as ofensas racistas que os jogadores negros ouviam da própria torcida há poucas décadas quando atuavam pelo Palmeiras praticamente desapareceram.

Podemos afirmar que o ingresso de jogadores negros na equipe principal do futebol corintiano no início dos anos 1930 ocorreu na mesma época em outras equipes de São Paulo. Apenas o Palestra Itália resistiu à contratação de jogadores negros, mas só por uma década. E alguns dos jogadores negros do Corinthians reforçaram a equipe palestrina em amistoso contra o Boca Juniors de Buenos Aires. ${ }^{573}$ São Paulo, Portuguesa, Santos e o Guarani da cidade de Campinas contavam com jogadores negros no início da década de 1930. Bino, por exemplo, sagrou-se campeão pelo São Paulo da Floresta, em 1931. ${ }^{574}$ Em 1933, Valdemar de Brito já fazia parte do elenco são-paulino.

A integração de jogadores negros na equipe principal não foi fenômeno exclusivo do Corinthians. Em um ambiente competitivo, em que os principais jogadores de

${ }^{572}$ UNZELTE, C. Idem, Ibidem. O autor informa, que ao se aposentar do futebol, Jaú tornou-se pai-desanto, servindo de inspiração para o programa humorístico Show de Bola, apresentado na Rádio Jovem Pan, entre os anos de 1967 e 1982. O personagem corintiano no programa seria uma caricatura de Jaú. As caricaturas são-paulinas e palmeirenses se fundavam nas representações existentes em torno dos torcedores de cada equipe, não na figura de um jogador de cada equipe. Assim, o personagem são-paulino era a caricatura de alguém que pertencia à elite paulistana com suas afetações e trejeitos, e o personagem palmeirense era a caricatura de alguém que morava em um dos bairros da comunidade ítalo-paulista e que, embora agraciado por uma comenda, mantinha-se profundamente rude e ignorante. Cada personagem não era propriamente um elogio aos clubes, seus jogadores e torcedores. A escolha do jogador negro e pai-de-santo como referência ao time corintiano tinha conotação de chacota, não de elogio, algo que nos permite perceber que o imaginário que define a identidade corintiana como clube de negros possuía um aspecto racista por parte dos simpatizantes de outras equipes contra os torcedores corintianos, dentro de uma sociedade marcada pelo racismo em todos os grupos sociais.

573 Os "cinco gigantes negros que o Palestra poz em campo para arrazar com o Boca", depois da superioridade dos visitantes nos primeiros minutos de jogo. A Gazeta. 02/03/1935. Pág. 9.

${ }^{574}$ GIACOMINI, C. São Paulo. Dentre os grandes, és o primeiro. Op. Cit. Pág. 28. 
ascendência italiana conseguiram contratos profissionais na Europa, em que os bons jogadores remanescentes migraram para o Rio de Janeiro, as equipes de São Paulo não tiveram escolha e abriram-se aos atletas negros.

Em São Paulo, se os negros não eram aceitos como associados dos clubes de elite, foram aceitos como jogadores de equipes rivais desses clubes a partir da cisão de 1926.

As fontes sugerem que o ingresso desses jogadores negros nos quadros das equipes que atuavam no Campeonato Paulista ocorreu por conta da cisão que deu origem à LAF. Naquela ocasião, algumas equipes que foram aceitas nessa entidade contavam com jogadores negros em seus quadros. ${ }^{575}$ Contraditoriamente, a liga criada pelo Paulistano, o mais elitista dos clubes de São Paulo, organizada para acabar com o profissionalismo e manter um futebol seletivo e elitizado - pelo menos em discurso, foi a primeira liga que contou com esses jogadores em profusão. E, a partir da unificação de dezembro de 1929, todas as equipes que atuavam no Campeonato Paulista contaram com a participação de jogadores negros, exceto o Palestra Itália.

A presença desses jogadores em algumas das equipes que disputavam o

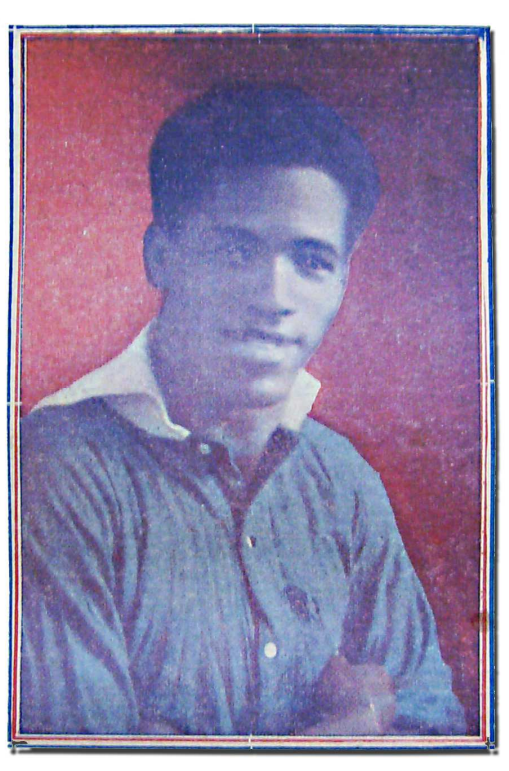
campeonato da LAF, em nossa opinião, contradiz o argumento das equipes que romperam com a APEA, e que o que buscavam era uma purificação dos campos de futebol. Era apenas mais uma das infindáveis brigas entre dirigentes pelo controle do futebol. E, dessa briga, os primeiros jogadores negros despontaram nos gramados paulistanos, em equipes como o Guarani de Campinas, ${ }^{576}$ Syrio, Portuguesa e São Bento, ${ }^{577}$ justamente contra equipes elitistas como Paulistano, Germânia e A. A. das Palmeiras.

Interessante notar que apenas a equipe corintiana

\footnotetext{
${ }^{575}$ Os astros da dissidência. A Gazeta Esportiva. 27/05/1929. Pág. 3.

${ }^{576}$ O campeonato paulista. A Gazeta Esportiva. 22/06/1930. Pág. 4. Foto com dois jogadores negros do Guarani, Nena e Paulo.

577 Os astros da dissidência. A Gazeta Esportiva. 27/05/1929. Pág. 3. A trajetória de Romeu Augusto Nabuco, jogador negro que atuou pelas equipes do Syrio, Portuguesa e São Bento em cada campeonato organizado pela LAF, entre 1926 e 1929.
} 
construiu o imaginário relacionado à comunidade negra de São Paulo, já que as outras equipes tinham um público torcedor muito semelhante e não forjaram a mesma identidade. $^{578}$

E se, desde 1919, um estilo brasileiro de jogar futebol era percebido pelos cronistas dos periódicos por suas características singulares marcadas pela individualidade, ${ }^{579}$ a partir das décadas de 1930 e 1940, esse estilo encontrou, em atletas negros que atuaram pelas principais equipes de São Paulo, como Leônidas da Silva, Servílio, Og Moreira e Teleco, seus principais defensores, uma atividade que permitiu algum tipo de ascensão social para esses homens, por meio do futebol. E, desde então, a presença desses atletas nos gramados é recorrente em todas as equipes, mesmo que nunca ascendam aos postos de comando dos clubes ou que permaneçam como proletários do futebol.

Entre as torcidas das três equipes, ocorreu processo semelhante, pois, em nossos dias, os simpatizantes negros estão presentes nas arquibancadas por meio das torcidas organizadas ou não, são fundamentais como consumidores do espetáculo futebol, e qualquer tipo de discurso ou ato racista costuma ser combatido por não ser visto como algo aceitável, ${ }^{580}$ inclusive entre simpatizantes do Palmeiras.

Na trajetória corintiana, também chama a atenção o fato de filhos de imigrantes de outras nacionalidades se identificarem com a equipe. Por que, na década de 1930, os espanhóis se vincularam à equipe corintiana e não construíram a sua equipe de colônia ou se filiaram ao Espanha, de Santos?

As leituras realizadas indicam que a construção de um imaginário corintiano atrelado às comunidades espanholas e negras foi o resultado dos conflitos étnicos da década de 1930, marcada pela formação de intensas rivalidades entre as equipes palestrina e corintiana, do surgimento do termo derby e de apogeu do fascismo no

\footnotetext{
578 Além disso, não sabemos o que aconteceu com clubes formados exclusivamente por negros, como desapareceram ou se foram incorporados por meio de fusões em outras equipes. Só uma pesquisa aprofundada sobre as relações raciais entre jogadores e clubes de São Paulo poderá nos mostrar o que aconteceu com as equipes negras que existiam no início do século, como seus jogadores se relacionavam com os jogadores dos times formados pelos filhos de imigrantes e os conflitos decorrentes desse convívio. ${ }^{579}$ FRANZINI, F. Op. Cit. Pág. 74.

${ }^{580}$ A torcida organizada Mancha Verde, do Palmeiras, realizou protesto contra a contratação do técnico Antonio Carlos Zago, que, quando jogador, protagonizou cenas de racismo contra colegas negros, dentro de campo. O jogador foi flagrado pelas câmeras de TV ofendendo um jogador negro de time adversário com ofensas racistas. Antônio Carlos ignora protesto da Mancha. Sítio da Internet Lancenet. 21/02/2010. (http://www.lancenet.com.br/noticias/10-02-21/704893.stm).
} 
Palestra Itália. E, nesse período, não mais encontramos referências nos jornais aos times de futebol formados exclusivamente por jogadores negros, pois, ao que tudo indica, dentro do ideário de miscigenação proposto pelo governo Vargas, eles foram incorporados aos grandes times do futebol oficial/profissional ou se converteram em agremiações varzeanas oficialmente sem qualquer restrição racial ou étnica, fornecedoras de jogadores às grandes equipes. Em outros esportes, no entanto, clubes para negros fundados por negros ou problemas de interdição dos espaços desportivos aos negros em clubes de brancos ou de elite continuaram a acontecer. ${ }^{581}$

O Corinthians não foi o único time adotado pelas comunidades pobres, mas, por ser o maior time da cidade sem vínculo direto com a comunidade ítalo-paulista ou o consulado italiano, que, por algum tempo, teve dirigentes de origem espanhola, ou de origem suíça, que gozavam da simpatia dos filhos de outras comunidades imigrantes que não lograram construir uma equipe de colônia e possuir uma identidade de clube operários, conseguiu estabelecer uma identificação mais fácil com essas parcelas da população. Por fim, cabe salientar que, naqueles idos de 1930, a equipe corintiana sentiu as crises geradas pelas cisões como os demais clubes e, para superá-la, os dirigentes tiveram que abrir o clube para esses torcedores e associados, o que, provavelmente, não foi um imperativo ao Palestra Itália.

A dinâmica urbana da cidade cuidou de afastar os dois clubes ainda mais, na medida em que transformou o bairro em que está o Palestra Itália em bairro de classe média, habitado, majoritariamente, por brancos descendentes de italianos, que se transformaram em sócios do clube, enquanto o Corinthians acabou sitiado pela Avenida Marginal do Tietê, em um bairro predominantemente operário até os idos de 1980, na região mais populosa da cidade, a zona leste.

\footnotetext{
${ }^{581}$ O Clube Negro de Cultura Social commemorou, brilhantemente, a data da abolição da escravatura. $A$ Gazeta Esportiva. 14/05/1934. Pág. 13; Patinação e hockey. Pretos X Brancos. A Gazeta Esportiva. 12/06/1932. Pág. 6.
} 


\subsection{O time que popularizou o futebol? ${ }^{582}$}

"O incomparável insider, que contribuiu decisivamente para a conquista do campeonato sul-americano de 1919, está com o rosto cheio de fase do seu aparecimento em futebol de primeira classe, aí por 1916. A seguir, o rosto de Neco se cavou e veio-lhe a calvície. A consagração de Manuel Nunes marca a intensificação da popularização do futebol, deixando longe o predomínio dos filhos de papai. Rubens, os Rubiões, ou Egídios, e tantos cariocas, foram ases feitos na quadra dos filhos de papai, quando o futebol era quase um privilégio de famílias importantes. Com o grande corintiano multiplicam-se os campeões procedentes das camadas populares. Principiou, na história do soccer brasileiro, a fase das multidões." 583

"Os cinco quase não dormiram, na noite de 31 de agosto para $1 .^{\circ}$ de setembro. Cada qual traçava seus planos de argumentação, para que maior possibilidade de êxito tivesse a ideia. Oito e meia da noite do dia $1 .^{\circ}$ de setembro de 1910 . Plena via pública. Rua José Paulino. Debaixo de um lampião de gás. Noite enfeitada de estrelas. Foi assim, nesse cenário, que se reuniu pela primeira vez - 13 pessoas não mais - a gente que pretendia fundar um clube de futebol no Bom Retiro."

"De um extremo ao outro, do Corinthians, de ponta a ponta de sua história, a mesma sofreguidão, o mesmo sofrimento passivo e o mesmo amor ativo. Corintiano, quando sofre, chora. Quando é feliz, chora." ${ }^{, 55}$

"Há ainda a história de sua briga com Manuel Domingos Corrêa, que acabou sendo o $18 .^{\circ}$ presidente do Corinthians. A briga começou em 1913, quando o Corinthians jogou contra o Minas Gerais, para saber quem entraria na Liga Paulista de Futebol. Ao entrar em campo, Neco, que tinha 16 anos, ouviu alguém gritar que o Corinthians era time de carroceiro. Tirou a cinta e correu para cima do homem. Foi uma confusão tremenda. Domingos era homem rico, dono de uma loja de cofres. Depois da nossa briga, nunca mais o vi, até o dia em que entrei no Parque São Jorge e ele era o tesoureiro. Fiquei triste, pois nem ao menos o homem era corintiano e só estava lá por causa do dinheiro que tinha."

\footnotetext{
582 Não é objetivo deste trabalho discutir conceitos como popular, popularização ou massificação e suas diferenças. Baseamos nossa reflexão nos termos propostos pelo Dicionário Aulete Digital da Língua Portuguesa.

${ }^{583}$ VALENTIM, M. O futebol e sua técnica. Pág. 68.

${ }^{584}$ DE VANEY. História. Corinthians. Campeão dos Centenários. Op. Cit. Pág. 10.

${ }^{585}$ SILVA, Alcides da. Templo impenetrável. Corinthians. Campeão dos centenários. Pág. 8.

586 JAMES, Narciso e ADAUTO, Flávio. Corinthians, campeão do povo. Folha de S. Paulo. 23/12/1974.

Pág. 7. Suplemento Especial. Apud NEGREIROS, P. Op. Cit. Pág. 128.
} 
Ao estudar a fundação do Corinthians, Plínio Negreiros se propôs a compreender o processo que fez com que um clube pudesse ajudar na popularização do futebol. ${ }^{587}$

$\mathrm{O}$ autor percebeu que, independentemente da veracidade dos fatos narrados e das análises apresentadas, o Corinthians e seus simpatizantes construíram uma identidade que se relaciona com uma trajetória sedimentada ao longo dos anos em torno de ideias como conquistas obtidas em meio a grandes dificuldades, superação, a origem operária, entre outros. ${ }^{588}$ Títulos, partidas, sedes sociais ou campos de futebol, segundo essas narrativas, foram frutos de conquistas árduas, razão pela qual, todo torcedor corintiano que se preze exige, na atualidade, que os jogadores joguem com garra e amor à camisa.

Cabe indagar, no entanto, se narrativas semelhantes de superação e dedicação não existiram nas trajetórias do São Paulo Futebol Clube e da Sociedade Esportiva Palestra Itália/Palmeiras. E, como vimos, os dois clubes também as têm. As narrativas acerca do Lampião de $G a s^{589}$ ou mesmo da origem operária do Corinthians são interessantes para os envolvidos com o futebol por dois motivos: servem para consolidar a identidade corintiana, marcada pela origem operária de alguns de seus fundadores e pelo início varzeano, com uma ascensão dentro do futebol oficial que alimentou os sonhos de todas as equipes varzeanas que vieram depois; e ajudam a consolidar o imaginário elitista sobre as práticas futebolísticas da cidade por volta da década de 1910, na medida em que o Corinthians teria sido o responsável por popularizar o futebol na cidade de São Paulo, a partir do momento em que tentou ingressar na LPF.

Os eventos que marcaram o ingresso do Corinthians na Liga Paulista de Futebol no início de 1913 e que foram estudados por Negreiros são pouco documentados. O

\footnotetext{
${ }^{587}$ NEGREIROS, Plínio José Labriola de Campos. Op. Cit. Págs. 105 e 106. Ciente da polissemia que o termo comporta, o autor resgata autores como Chaú e Thompson para informar que o sentido de popularizar é o da criação de uma representação por aqueles que nada possuem e se organizam para reivindicar direitos tácitos e penetrar no universo dos direitos políticos e culturais explícitos.

${ }^{588}$ NEGREIROS, P. Op. Cit. Págs. 108 e 110. Relatos produzidos por todo o século XX que vinculam as dificuldades da equipe às dificuldades vivenciadas pelas populações pobres de São Paulo.

${ }^{589}$ PASSOS, Maria Luiza Perrone. A cidade iluminada. Postes de São Paulo (1899-1930). (In): PASSOS, Maria Lúcia Perrone \& EMÍDIO, Teresa. Desenhando São Paulo. Mapas e literatura. Pág. 108. Entre 1899 e 1929, o sistema de iluminação elétrica das ruas era precário, embora existente. Clubes de elite fundados em anos anteriores, como o SPAC, ou no contexto de instalação da energia elétrica na cidade, como Internacional e Germânia, também foram fundados sob a luz de um lampião e este fato não se transformou em uma narrativa mítica como a narrativa corintiana.
} 
autor encontrou apenas algumas referências em um dos periódicos consultados, $O$ Comércio de São Paulo: ${ }^{590}$

"No dia seguinte ao jogo em que o SCCP ganhou o direito de ingressar na LPF, a diretoria dessa entidade reuniu-se com representantes dos clubes filiados e, ouvindo o parecer favorável à entrada do SCCP feita pela comissão de sindicância, resolveu também aprovar a entrada do clube vencedor. Não foi possível determinar se a decisão foi ou não tomada de forma unânime.",591

Pela leitura do jornal, Negreiros constata a existência de um debate dentro da Liga, sobre a conveniência de se autorizar ou não o ingresso do Corinthians na Liga. A nota publicada diz:

"Acredita ele, por acaso, que desocupados e desordeiros sejam capazes de um procedimento correto e honroso como o que ontem acompanhou os rapazes do Corinthians? Pensam os sindicadores que indivíduos que não escapam àquela classificação tenham, numa luta de honra, a compostura dos valentes Corinthians? E mais, será possível que, em condições tão especiais, especialíssimas mesmo, rapazes, sem educação e afeitos a um meio diverso do nosso, tenham aquela bela compostura que ontem foi a nota dos Corinthians?"

A trajetória corintiana entre setembro de 1910 e abril de 1913 também é pouco documentada. Os relatos jornalísticos são esparsos e, quando trazem citações, são pequenas notas com informações referentes a partidas, escalações e adversários, algo que acontecia com outros tantos times varzeanos no período. ${ }^{593} \mathrm{Em}$ pesquisa publicada no Almanaque do Timão, Celso Unzelte afirma que os poucos dados existentes para 1910 foram preservados por meio do trabalho de Antônio de Almeida, um dos sistemáticos colaboradores da Revista Corinthians, que foi editada pela primeira vez na década de 1930 e retomada com regularidade apenas no final da década de 1940. Ele informa que, em 1910, o Corinthians realizou jogos contra o União Lapa, perdido por 1

\footnotetext{
${ }^{590}$ NEGREIROS, P. Op. Cit. Pág. 141. O silêncio de outros periódicos é constatado pelo autor.

591 NEGREIROS, P. Op. Cit. Pág. 143. A nota foi publicada pelo O Comércio de São Paulo, em 31/03/1913.

${ }^{592}$ NEGREIROS, P. Op. Cit. Pág. 142.

${ }^{593}$ NEGREIROS, P. Op. Cit. Pág. 107. O autor apresenta o levantamento que realizou em sua dissertação de mestrado sobre os periódicos que noticiaram a fundação do Corinthians. Apenas $O$ Comércio de São Paulo e $O$ Estado de $S$. Paulo publicaram notas informativas da fundação da nova associação, no dia 22/09/1910.
} 
X 0, em 10 de setembro, contra o Estrela Polar, vencido por 2 X 0, em 14 de setembro, e A.A. da Lapa, vencido por 5 X 0, em 27 de setembro. ${ }^{594}$

Algumas partidas disputadas entre 1911 e 1912 não tiveram seus resultados publicados pelos jornais da época e se perderam. Pelo levantamento de Unzelte, em 1911, a equipe corintiana atuou pelo menos uma vez no Parque Antarctica contra uma equipe chamada Cambridge e uma vez no campo da Chácara da Floresta contra o $3^{\circ}$ time da A.A. das Palmeiras. ${ }^{595}$ Apenas em 1913, atuou pela primeira vez no Velódromo Paulista, por ocasião da seletiva para ingressar no Campeonato Paulista. ${ }^{596}$ Segundo o mesmo autor, algumas partidas entre 1910 e 1912 foram disputadas no campo do time na Rua dos Imigrantes, no Bom Retiro, uma na várzea da Lapa, outra no Prado da Moóca e duas em Campinas. Unzelte não conseguiu identificar todos os lugares em que a equipe disputou partidas de futebol em seu período varzeano. ${ }^{597}$

O histórico publicado por De Vaney no Álbum Corinthians. Campeão dos Centenários informa que o campo corintiano ficava em um terreno da Rua José Paulino que dava para a Rua Ribeiro de Lima e que, na Rua dos Imigrantes, n. ${ }^{\circ} 34$, esquina com a Rua Cônego Martins, ficava a confeitaria de Afonso Desidério, utilizada como sede nos primeiros tempos. ${ }^{598}$ Segundo o autor, em 14 de setembro de 1910, os fundadores trabalharam no aplainamento, nivelamento e armação das traves para que a equipe pudesse treinar em algum lugar e a partida contra o União Lapa teria sido disputada semanas mais tarde. ${ }^{599}$

No Arquivo do Estado, o documento corintiano mais antigo que encontramos data de 1916. O próprio clube quase não possui documentos arquivados do período 1910/1912, apenas uma fotografia da primeira conquista esportiva do clube e sua taça, no pedestrianismo. Em pesquisa realizada no Museu do Corinthians, verificamos que o

\footnotetext{
594 UNZELTE, C. Almanaque do Timão. Pág. 22. DE VANEY. História. Corinthians. Campeão dos Centenários. Pág. 12. O autor informa que a segunda partida foi disputada contra a A.A. Lapa, time formado por jogadores britânicos.

${ }^{595}$ UNZELTE, C. Op. Cit. Págs. 22 e 23.

${ }^{596}$ UNZELTE, C. Op. Cit. Pág. 24.

${ }^{597}$ UNZELTE, C. Op. Cit. Págs. 22 e 23.

${ }^{598}$ DE VANEY. História. Corinthians. Campeão dos Centenários. Pág. 12.

${ }^{599}$ DE VANEY. Op. Cit. Pág. 12.
} 
documento escrito oficial mais antigo produzido e arquivado pelo clube data de abril de 1913, quando a equipe já ingressara no campeonato organizado pela Liga. ${ }^{600}$

Por esse documento, descobrimos que a sede social do clube naquela ocasião ficava na Rua Guarany, n. ${ }^{\circ}$ 18, no bairro do Bom Retiro, verificando a presença de alguns nomes entre os sócios que, no ano seguinte apareceriam como associados do Palestra Itália. ${ }^{601} \mathrm{E}$ que, principalmente, a diretoria tentava aprovar entre os sócios a isenção de mensalidades entre aqueles que atuavam pelos dois principais quadros de futebol do clube ${ }^{602}$. Essa era uma das estratégias adotadas pelas equipes que disputavam o campeonato para reforçar seus times. Com essa medida, a equipe corintiana teria melhores condições de cavar jogadores de outras equipes que atuavam na Várzea.

As fontes sugerem que o principal fornecedor de jogadores para o Corinthians, naquele contexto, foi uma outra equipe do Bom Retiro, a A. A. Botafogo. Negreiros aponta, em sua pesquisa, por meio da memória produzida pelos relatos dos primeiros sócios, que esse clube teria sido uma espécie de antecessor do Corinthians. ${ }^{603}$

600 Trata-se de uma Ata de uma Assembléia Geral Extraordinária realizada em 11 de abril de 1913. Segundo Unzelte, as partidas seletivas foram disputadas nos dias 23 e 30 de março de 1913. UNZELTE, C. Op. Cit. Pág. 24.

${ }^{601}$ Figuras entre os primeiros. Lance. 1/09/1910. Além da ata, encontramos uma entrevista produzida pelo periódico Lance com o filho de um dos pioneiros do Corinthians e do Palestra Itália. A entrevista foi com Luis Fabbi Júnior, filho de Luis Fabbi, primeiro centroavante do Corinthians, nascido em Parma e que marcou o primeiro gol da história do clube. Segundo o entrevistado, em 1913, o Corinthians precisou do apoio de um empresário para confeccionar uma bandeira, que exigiu em troca que o filho fosse escalado como centroavante da equipe. Descontente com a situação, Luis Fabbi afastou-se do clube e, no ano seguinte, convidado pelo irmão, ajudou na fundação do Palestra Itália. Lá, ficaram conhecidos como irmãos Fabbi (Luigi e Maturio ou Fabbi I e Fabbi II).

${ }^{602}$ Acta da Assembléia Geral Extraordinária realizada em 11 de abril de 1913, na Rua Guarany 18. Estiveram presentes os seguintes sócios: Alexandre Magnani, Salvador Lopomo, Cesar Nunes, Luis Fabbi, Casemiro do Amaral, Jorge Campbell, Anselmo Corrêa, Francisco Polici, Francisco Lepre, João da Silva, Fúlvio Valêncio, Paschoal Altieri, Joaquim Rodrigues, Manuel Nunes, Domingos Império, Américo Fiaschi, João Massário, Attilio Fredi, Guido Orlandi, João Maurino, Manoel de Ferreira, Arthhur Fabbi, Caetano Baroni Baptista de Bono, Antonio Mastri, Américo de Souza, Alfredo Ipessoni, Salvador Federico, Luis Fabbi Filho, Benedicto da Cunha, Augusto Corrêa e Salvador (ilegível).

${ }^{603}$ NEGREIROS, P. Op. Cit. Pág. 119. "Este clube, na literatura apaixonada e nos depoimentos dos primeiros sócios do Sport Club Corinthians Paulista, aparece como o antecessor do próprio Sport Club Corinthians Paulista. Narra-se que havia um clube de futebol muito briguento, chamado Botafogo. E que, em virtude de tantas brigas, o delegado de polícia da região resolveu fechá-lo. Logo após este fato, funda-se o Sport Club Corinthians Paulista, espécie de espólio do Botafogo. Mas o mais interessante é que um tal Botafogo, a A.A. Botafogo, com campo na Rua Paula Souza - próximo à Estação da Luz - , continuava a existir. E, de fato, o Sport Club Corinthians Paulista era muito ligado ao Botafogo. Tanto que os jogadores eram os mesmos. Até 1916, nota-se que os times eram praticamente iguais." O autor define como literatura apaixonada, todas as publicações produzidas pelo clube, por periodistas ou por torcedores que não tivessem características acadêmicas. 
Como havíamos sugerido quando discutíamos a fundação do Palestra Itália, pensamos na existência de um circuito futebolístico relativamente fechado, no qual os bons jogadores atuavam por diversas equipes ao mesmo tempo. Também o Palestra Itália cavava seus jogadores em outras equipes da cidade como o Ruggerone da Lapa. ${ }^{604}$ Não foi improvável que alguns jogadores chegassem a atuar por três ou mais equipes ao mesmo tempo. O jogador Police, por exemplo, atuou por Corinthians, Botafogo do Bom Retiro, Scottish Wenderers, Palestra Itália e Scraths do Bom Retiro, entre 1913 e 1916, antes de se transferir para o Botafogo do Rio de Janeiro.

Em nossa hipótese, quando o Corinthians propôs o ingresso na LPF, jogadores que atuavam por outras equipes e que poderiam reforçar o time para o torneio seletivo foram cavados, em especial no Botafogo do Bom Retiro, pela possibilidade de jogar na principal Liga de futebol da cidade e pela isenção de mensalidades aprovada aos jogadores das equipes corintianas. A única foto da equipe do Botafogo que está arquivada no Corinthians foi enviada por um torcedor de Piracicaba, em 1956, para a Revista Corinthians e nela aparecem os jogadores Amílcar, Police, César Nunes, Apparício e Pizzocaro, ${ }^{605}$ entre outros.

Também aventamos a hipótese de que aquele pequeno grupo de amigos do Bom Retiro, que se juntara para jogar futebol nas várzeas de São Paulo, só se preocupou em organizar-se juridicamente a partir do momento em que tentou ingressar na Liga Paulista de Futebol, entre fins de 1912 e a primeira metade de 1913, pois encontramos, no Arquivo do Estado, a cópia da reforma estatutária realizada pelo clube em 1916. E por essa reforma, aprovada em 12 de fevereiro de 1916, verificamos a existência de um estatuto anterior, elaborado em 11 de julho de $1913,{ }^{606}$ sem qualquer referência a estatutos e documentos mais antigos.

\footnotetext{
${ }^{604}$ A várzea torce hoje, com o coração, pelo embate Palestra-Corinthians. A consagração dos que vivem nas várzeas e subúrbios. A Gazeta Esportiva. 04/05/1930. Pág. 9.

${ }^{605}$ UNZELTE, C. Timão. 100 anos. 100 jogos, 100 ídolos. Pág. 13. O autor não informa a data da fotografia.

606 Estatuto corintiano aprovado em 11/07/1913 e reformado em 12/02/1916. C 10418.479 C.
} 


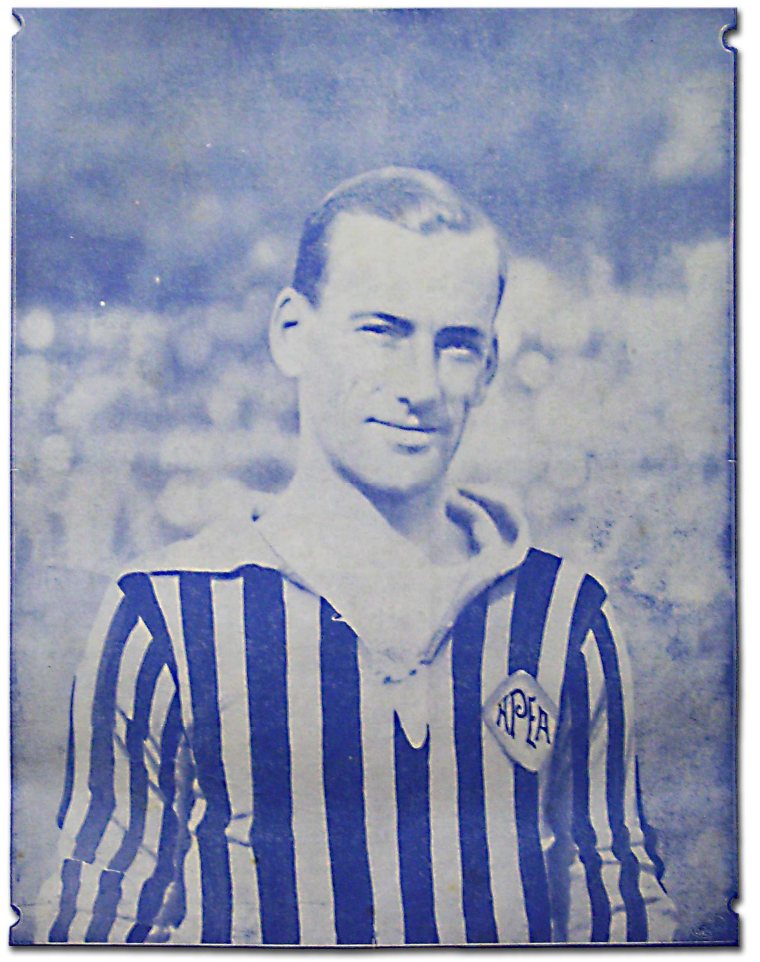

10. Amílcar Barbuy no final da carreira.
Isso teria ocorrido porque a LPF exigia, como condição para a participação no campeonato, que o clube provasse sua existência por meio dos estatutos. $\mathrm{O}$ ingresso do Corinthians na LPF ocorreu depois da disputa de um torneio seletivo contra as equipes do Minas Gerais Futebol Clube, do São Paulo Railway e do São Paulo do Bexiga. ${ }^{607}$ A cópia que consultamos no Arquivo do Estado data de março de 1914. O artigo $13 .^{\circ}$ daquele estatuto da LPF afirmava que

"Para que um novo clube possa filiar-se à Liga deverá:

a) Provar sua existência regular, enviando-lhe os seus estatutos em vigor;

b) Provar que joga football association de conformidade com as regras por ella aprovadas;

c) Provar que possui um campo com as dimensões legaes;

d) Designar quaes as cores com que jogarão os seus teams e o modo por que estão dispostas no uniforme;

e) Designar o domicílio do presidente e do secretário."

O estatuto corintiano encontrado no Arquivo do Estado apresenta alguns aspectos que chamaram nossa atenção como o fato de o artigo $4 .^{\circ}$ dar a prerrogativa dos jogadores escolherem capitães e diretores esportivos e o artigo $5 .^{\circ}$ isentar de mensalidade os jogadores dos dois times de futebol, o que indica que a estratégia para cavar jogadores de outras equipes discutida na ata de 1913 fora aprovada. Por fim, trás

\footnotetext{
607 SALUN, A. O. Op. Cit. Pág. 54. O autor avisa que as informações são discordantes, pois alguns autores sugerem que o SPR disputou a seletiva e outros autores dizem que não.

${ }^{608}$ Estatutos da Liga Paulista de Futebol de 16/06/1914. Arquivo do Estado. C 10415.452
} 
a informação de que os jogadores corintianos só poderiam atuar por outras equipes com o consentimento da diretoria. ${ }^{609}$

Provavelmente, o ingresso do Corinthians na LPF causou polêmica, menos pela origem social dos jogadores e mais pelo aparecimento de uma nova equipe que era dirigida por pessoas que conheciam os mecanismos para arregimentar bons jogadores de outras equipes da várzea e que, nesse sentido, tornavam o Corinthians um forte concorrente das demais equipes da LPF e não um simples fornecedor de jogadores. Em 1915, o Corinthians não teve autorização para jogar o campeonato da APEA, embora tenha se filiado à entidade. Naquela ocasião, o Paulistano se recusou por diversas ocasiões a disputar uma partida amistosa contra a equipe corintiana, mas os jogadores corintianos atuaram por outras equipes sem qualquer restrição naquele campeonato, inclusive contra o Paulistano ${ }^{610}$. As equipes que receberam o reforço desses jogadores não desejavam o ingresso do Corinthians porque perderiam seus reforços. ${ }^{611}$

As atividades econômicas dos fundadores também causam polêmicas. Segundo Alfredo Salun, Miguel Bataglia era alfaiate, Alexandre Magnani era cocheiro nos arredores da Luz, enquanto Joaquim Ambrósio, Carlos da Silva, Rafael Perrone e Anselmo Correia eram funcionários da oficina mecânica da empresa São Paulo Railway no bairro da Lapa. Antonio Pereira e José Gonzáles eram pintores de paredes e o primeiro também era empreiteiro. Afonso Desidério era confeiteiro e João Batista Maurício era dentista. O mesmo autor informa a existência de algumas divergências acerca dessas informações, que, de certo, apenas que a primeira diretoria foi formada por Miguel Bataglia, presidente, Alexandre Magnani, vice-presidente, Salvador Lopomo, secretário, Jorge Campbell, tesoureiro, Felipe Valente, procurador, João Morino, cobrador, João da Silva, Antonio Nunes e Carlos Silva, diretores especiais. ${ }^{612}$ Juca Kfouri informa que Miguel Bataglia, primeiro presidente do Corinthians, era inspetor de bondes da Light. ${ }^{613}$

\footnotetext{
609 Estatuto corintiano aprovado em 11/07/1913 e reformado em 12/02/1916. C 10418.479 C.

${ }^{610}$ MAZZONI, Thomaz. Espírito Varzeano. Amor corinthiano. Corinthians. Campeão dos centenários. Pág. 52.

${ }^{611}$ NEGREIROS, P. Op. Cit. Pág. 153. O autor encontrou uma pequena nota no O Comércio de São Paulo que afirma que o Mackenzie não desejava o ingresso do Corinthians por ter que devolver cinco ou seis jogadores insubstituíveis. O Comércio de São Paulo, 08/08/1915, também afirma que o convite da APEA ao Corinthians foi uma das estratégias adotadas para esvaziar a LPF. Pág. 161.

${ }^{612}$ SALUN, A. O. Op. Cit. Págs. 32 e 33.

${ }^{613}$ KFOURI, J. Corinthians. Paixão e glória. Pág. 52.
} 
Antonio Roque Citadini recolheu o depoimento que Antonio Pereira, um dos fundadores do Corinthians, deu à Folha de S. Paulo, em dezembro de 1974, no qual informa que a maioria dos fundadores trabalhava na São Paulo Railway Company: pintores, carpinteiros, barbeiro e carroceiros formavam o núcleo que deu origem ao clube; seriam sete italianos, cinco portugueses e dois brasileiros. ${ }^{614}$ Para Mazzoni, as reuniões preparatórias ocorreram em um salão de barbeiro da Rua dos Italianos que pertencia ao irmão do primeiro presidente, local em que foi lavrada a ata de fundação. A primeira sede teria sido instalada no bar e confeitaria de Afonso Desidério, que ficava na Rua Imigrantes, $34 .^{615}$

Robert Levine afirma que “(...) em São Paulo, os engenheiros e administradores ingleses da ferrovia fundaram o Corinthians em 1910, organizando o clube de maneira tradicional e apropriando-se do nome de um time inglês bem sucedido, mas alistando atletas entre os trabalhadores italianos do cais e entre outros operários, já conhecedores do esporte." 616

Plínio Negreiros recolheu uma ata de 1914 que, ao discutir a mudança do clube do Bom Retiro para o centro de São Paulo, apresenta dados interessantes sobre as atividades de um dos diretores/fundadores da equipe. $\mathrm{O}$ documento informa que, em 1914, Alexandre Magnani era dono de uma confeitaria na Rua dos Imigrantes, local em que o clube ocupava uma sala como sede. ${ }^{617} \mathrm{O}$ mesmo autor, ao discutir as ideias de Levine, concorda que não há garantias que o Corinthians tenha vivido de forma modesta em seus primeiros tempos nascido sob as mais humildes condições econômicas, como sugere seu mito de fundação. ${ }^{618}$

As fontes indicam que era um clube fundado por amigos, possivelmente vizinhos no Bom Retiro, que queriam jogar futebol e se inspiraram na visita do clube homônimo inglês para nomeá-lo. Evidentemente, não foi fundado pela elite paulistana, mas a

\footnotetext{
${ }^{614}$ CITADINI, A. R. Neco. O primeiro ídolo. Págs. 39 e 42.

${ }^{615}$ MAZZONI, T. História do Futebol no Brasil. Págs. 79 e 80 . O autor afirma que os fundadores e dirigentes iniciais foram Rafael Perrone, Jorge Campbell, Antonio Vizzone, Alfredo Teixeira, Felipe Valente, Emílio Lotito, Antonio A. Nunes, Carlos da Silva, Joaquim Ambrósio, Antonio Pereira, Anselmo Corrêa, Cezar Nunes, João da Silva e Salvador Lopomo. O cunhado de Afonso Desidério, João Batista Maurício, era dentista e foi o quarto presidente do Corinthians.

${ }^{616}$ LEVINE, Robert M. Esporte e sociedade. O caso do futebol brasileiro. (In): MEIHY, J. e WITTER, J. S. (Orgs.) Futebol e cultura. Pág. 25.

${ }^{617}$ NEGREIROS, P. Op. Cit. Págs. 132 e 133. Trata-se de Ata de Assembléia Geral Extraordinária do Sport Club Corinthians Paulista, de 20/10/1914.

618 NEGREIROS, P. Op. Cit. Pág. 111.
} 
presença de um dentista, um barbeiro, um alfaiate e alguns comerciantes entre seus fundadores sugere que pessoas de uma pequena classe média integravam o grupo.

Em depoimento prestado para A Gazeta Esportiva, em sete de setembro de 1930, Alexandre Magnani, Miguel Sottile e Felippe Valente informaram que o grupo era composto por, mais ou menos, dezoito rapazes e que foram necessárias diversas reuniões entre os dias $1 .^{\circ}$ e dez de setembro para definir a diretoria e o nome da equipe. Os três conseguiram apontar apenas mais alguns nomes como os de Raphael Perrone, Emílio Lotito, João Murino, Joaquim Ambrósio e Salvador Lopomo. ${ }^{619}$ Também informaram que o próprio Alexandre Magnani presidiu o Corinthians entre 1910 e 1914, quando o deixou para combater na Primeira Guerra. Faziam parte da equipe que disputou o primeiro jogo-treino do Corinthians contra a equipe do Estrela Polar os jogadores Valente, Perrone e Attílio, Lepre, Barone e Police, José Silva, Jorge Campbell, Luiz Fabbi, Cesar Nunes e Joaquim Ambrósio. ${ }^{620}$ Os três informam, também, que uma ata de fundação foi escrita de forma improvisada por ocasião das reuniões no início de setembro de $1910 .^{621}$

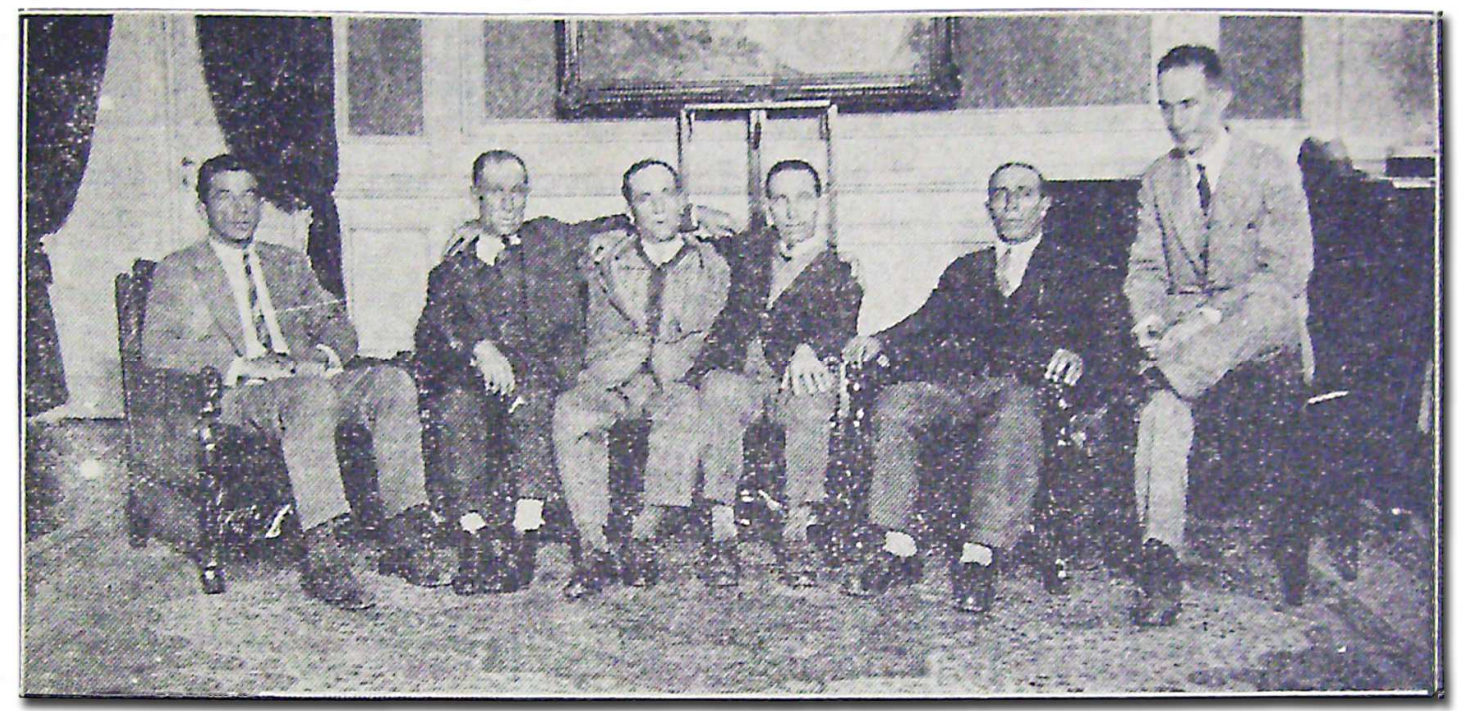

${ }^{619}$ Reconstituindo a história corinthiana. A Gazeta Esportiva. 07/09/1930. Pág. 2.

${ }^{620}$ Reconstituindo a história corinthiana. A Gazeta Esportiva. 07/09/1930. Pág. 2. Não há informações de em que condições ou para qual país lutou Alexandre Magnani, e de que Magnani não foi o primeiro presidente do Corinthians, pois Miguel Bataglia o dirigiu por alguns dias após a fundação do clube. Os três informaram que uma ata de fundação foi redigida em papel almaço.

621 Reconstituindo a história corinthiana. A Gazeta Esportiva. 07/09/1930. Pág. 2. 
Aventamos a hipótese de que os idealizadores daquele time de futebol, criado como atividade de lazer de jovens moradores do Bom Retiro, com o passar das partidas, perceberam que participar da Liga Paulista de Futebol poderia ser um bom negócio para eles mesmos, já que a equipe alcançara fama de imbatível na várzea e, se aceita na LPF, poderia arrecadar um bom dinheiro com os ingressos vendidos para as partidas dos campeonatos. Pelos dados colhidos por Alfredo Salun, descobrimos que o ingresso do Corinthians na Liga foi um bom negócio para o clube por dois fatores: a venda de ingressos no Parque Antarctica e a ampliação da arrecadação de mensalidade entre os sócios. Segundo o autor, as receitas corintianas em abril de 1913 foram de 614\$200 com a venda de ingressos no Parque Antarctica, 116\$000 com as mensalidades de sócios e $190 \$ 000$ com rateios. Em junho do mesmo ano, foram de $265 \$ 900$ com a venda de ingressos e $226 \$ 000$ com mensalidades de sócios. ${ }^{622}$ Os dados surpreendem pela importância que a venda de ingressos adquiriu nas finanças do clube e pelo aumento considerável entre abril e junho, dos valores arrecadados com as mensalidades de associados.

Se levarmos em consideração que, nos primeiros anos de existência do clube, a sede social era um bar ou confeitaria, não é difícil supor que a ampliação de sócios também representou o aumento no movimento desses estabelecimentos. Aliás, por que donos de bares e confeitarias estariam envolvidos com a fundação de um time de futebol e manteriam a sede do clube no próprio estabelecimento comercial se não fosse para vender bebidas aos jogadores, sócios ou torcedores?

Toledo defende a importância dos bares como espaços de convívio e interação social muito importantes para o futebol. ${ }^{623}$ Embora o autor tenha pensado o contexto contemporâneo, suas reflexões são sugestivas para compreendermos o que era o Corinthians ao tempo de sua fundação: um time de bairro, formado por amigos que se reuniam em algum bar ou confeitaria do Bom Retiro, provavelmente naquele que era mantido pelo presidente do clube ou algum dirigente, nos finais de semana, para se sociabilizarem depois das partidas de futebol e que, ao ingressarem na LPF, conseguirem construir uma identidade com os habitantes mais pobres da cidade, na medida em que o Corinthians foi o primeiro time oriundo do futebol de várzea que disputou o principal campeonato da cidade.

\footnotetext{
${ }^{622}$ SALUN, A. Op. Cit. Pág. 34.

${ }^{623}$ TOLEDO, L.H. Op. Cit. Pág. 289.
} 
Além disso, por ficar invicto por quase três anos, entre 1914 e 1917, construiu uma identidade de time vencedor, em que os atletas e a equipe se destacavam em um universo competitivo como representantes do bairro, comunidade ou, neste caso, do futebol varzeano diante do futebol oficial. Possivelmente, a magia que envolveu o Corinthians desde 1913/1914 passa por esses elementos, pois o universo social masculino da cidade de São Paulo, durante boa parte do século XX, passou pela combinação de bares e campos de futebol.

Isso não significa que fosse o time do povo para o povo ou contasse com a simpatia dos anarquistas, por exemplo. As evidências sugerem que o Corinthians foi fundado para que seus sócios praticassem o futebol. ${ }^{624}$ A diferença com o Palestra Itália reside no fato de este ter sido fundado com a intenção de criar uma equipe principal, para atuar em uma das duas grandes Ligas, quando o Corinthians já era campeão de uma delas, o que exigiu do clube palestrino maior organização e especialização das atividades das equipes que disputaram os campeonatos. Todas as equipes que disputaram o Campeonato Paulista passaram por esse processo ou desapareceram com o passar dos anos, e mantiveram atividades amadoras em que seus sócios disputavam torneios internos, inclusive, os dirigentes. ${ }^{625}$

Com o Corinthians, não foi diferente. O envolvimento com os campeonatos da LPF (1913 - 1916) e da APEA (1917 - 1934) promoveu a especialização das atividades dentro do clube rapidamente. Ainda na década de 1910, as atas determinavam que jogadores escolhessem capitães e dirigentes esportivos, como vimos anteriormente. Mas com o ingresso na LPF e com os esforços empreendidos nesse sentido, o comando do clube passaria das mãos dos fundadores para pessoas que não eram operárias, mas detinham algum prestígio social. Empresários, dentistas, médicos e militares passaram a ocupar a função que jamais foi exercida por alguém que tenha jogado futebol nos quadros principais da equipe corintiana.

Em 1916, encontramos jogadores como dirigentes. Naquela ocasião, foram eleitos dirigentes do Corinthians: J. B. Maurício, presidente, Manuel Fonseca, vice-presidente, Heitor de Ros, primeiro secretário, Antonio Cavalcante, segundo secretário, Matheus

\footnotetext{
${ }^{624}$ SALUN, A. O. Op. Cit. Pág. 33.

${ }^{625}$ Fanfulla. Em setembro de 1914, por ocasião de um campeonato interno do Palestra Itália, que serviria de seletiva para a formação do primeiro time palestrino, encontramos os nomes de alguns fundadores e dirigentes escalados nos times que disputavam o torneio. 28/09/1914. Pág. 6.
} 
Constantino, primeiro tesoureiro, Hermógenes Barbruy, ou Barbuy, segundo tesoureiro, Bianco Spartaco Gambini, Manuel Nunes e Francisco Police, diretores esportivos, Casimiro Gonzáles, capitão do primeiro time e Mário Regonaschi, capitão do segundo time; os últimos cinco, jogadores dos dois quadros. ${ }^{626}$

A especialização de funções e atividades dentro das equipes derivou da profissionalização e da competitividade no Campeonato Paulista. No entanto, outros atores, além dos jogadores, participaram, desde os primórdios, para a viabilização das partidas. E isso também aconteceu nas escolas em que se praticava futebol nos demais clubes. $^{627}$ No caso corintiano, esse processo de especialização ocorreu diante da necessidade de triunfar sobre os dois principais adversários dos campeonatos organizados pela APEA, Palestra Itália e Paulistano, que, após a unificação das ligas no final de 1916, ganharam todos os títulos entre 1917 e 1922, ano em que o Corinthians, finalmente, se sagrou campeão da APEA.

E a especialização foi marcada por conflitos de todas as ordens. Em 1913, o descontentamento de alguns fundadores que foram substituídos por jogadores mais técnicos gerou desconforto e uma pequena rebelião. Anselmo Correia, por exemplo, perdeu a condição de goleiro titular do segundo quadro para um sócio mais novo, Sebastião Casado. Segundo Salun, na ata de 11 de julho de 1913, o problema foi discutido e resolvido pela intervenção do diretor de futebol, Casimiro de Abreu, que lembrou que os dois tinham os mesmos direitos na condição de sócios, devendo prevalecer a qualidade técnica entre eles para ver quem deveria ocupar a posição titular. $^{628}$

Naquele período, por ocasião do ingresso na LPF, para conseguir dinheiro de um empresário para a aquisição de uma bandeira, o clube abriu espaço para que o filho do patrocinador atuasse pela equipe. O jogador prejudicado, Luigi Fabbi, autor do primeiro gol da história do clube, inconformado, abandonou o time e, nos anos seguintes, ingressou nas fileiras do Palestra Itália. ${ }^{629}$

\footnotetext{
${ }^{626}$ Sports. Correio Paulistano. 7 de abril de 1916. Pág. 3.

${ }^{627}$ TOLEDO, L. H. Op. Cit. Pág. 246.

${ }^{628}$ SALUN, A. O. Op. Cit. Pág. 33.

${ }^{629}$ Figuras entre os primeiros. Lance. 01/09/2000. Pág. 11. Raphael Perrone também abandonou o Corinthians na época em que a equipe ingressou na LPF e, anos depois, tornou-se conselheiro do Palestra Itália.
} 
Às vezes, as situações eram inusitadas; por ocasião da partida contra o Minas Gerais, válida pelo torneio classificatório organizado pela LPF em 1913, um dos torcedores causou uma tremenda confusão ao chamar a equipe corintiana de equipe de carroceiros. Um dos jogadores reservas da equipe escutou a provocação e comprou a briga. Na década de 1940, o cidadão que ofendera os jogadores corintianos em 1913, assumiu a presidência do clube para desgosto do então ex-jogador envolvido na briga. ${ }^{630}$

Entre 1917 e 1920, a cidade de São Paulo viveu sob uma onda quase contínua de greves com ampla participação operária, ${ }^{631}$ o que não passou despercebido no clube. $\mathrm{O}$ estatuto aprovado em 15 de setembro de 1921 aponta a existência de uma caixa de auxílio aos jogadores em caso de acidentes durante as atividades esportivas e garantia que $10 \%$ da renda bruta do clube deveriam ser utilizadas para esses fins. ${ }^{632}$ Indício de que os jogadores que atuavam pelo Corinthians percebiam o processo de mercantilização a que o futebol estava exposto e os riscos que corriam enquanto profissionais ou semiprofissionais.

E, para entendermos o quanto os clubes eram populares, devemos comparar o quanto custava para alguém se filiar ao Corinthians, ao Paulistano, ao A.A. das Palmeiras e ao Palestra Itália.

O primeiro estatuto palestrino, de dezembro de 1914, em seu artigo $7 .^{\circ}$, informa que a taxa de admissão de um novo sócio era de $5 \$ 000$ e que aumentaria para $10 \$ 000$ quando o clube alcançasse 200 sócios. Determinava que fossem considerados sócios fundadores aqueles que contribuíram com $10 \$ 000$ a título de taxa de fundação, até o dia 30 de setembro de 1914 , e que pagassem mensalidades de $3 \$ 000 .{ }^{633}$ Pelo artigo $4 .^{\circ}$, verificamos que o sócio comum pagava mensalidade de $1 \$ 000 .^{634}$ Já o estatuto corintiano de 1916 , em seu artigo $6 .^{\circ}$, informa que o novo sócio deveria pagar $3 \$ 000$ mensais ao clube e joia de $5 \$ 000 .{ }^{635}$ A ideia de um sócio diferenciado só apareceria na década de 1920, quando o clube buscou o apoio de empresários.

\footnotetext{
${ }^{630}$ CITADINI, A. R. Op. Cit. Pág. 46. Segundo o autor, essa foi a primeira de muitas brigas do jogador Neco. O dirigente envolvido chamava-se Manuel Domingos Correa.

${ }^{631}$ MARAM, Sheldom Leslie. Anarquistas, imigrantes e o movimento operário brasileiro (1890 - 1920). Pág. 57.

${ }^{632}$ Estatuto corintiano aprovado em 15/09/1921. Arquivo do Estado. C 10418. 479 D.

${ }^{633}$ Estatuto palestrino aprovado em 15/12/1914. Arquivo do Estado. C 10415.440 A.

${ }^{634}$ Estatuto palestrino aprovado em 15/12/1914. Arquivo do Estado. C 10415.440 A.

${ }^{635}$ Estatuto corintiano aprovado em fevereiro de 1916. Arquivo do Estado. C 10418 - 479 C.
} 
O estatuto do Paulistano, também de 1916, em seu artigo 4. ${ }^{\circ}$, informa que o sócio teria que pagar mensalidade de $10 \$ 000$ e joia de $25 \$ 000 .{ }^{636}$ Já o estatuto da A.A das Palmeiras, aprovado em novembro de 1914, falava em mensalidades de $5 \$ 000$ e joia de $10 \$ 000 .^{637}$

Faz sentido quando pensamos nos valores cobrados por cada clube, pelos dados encontrados, falarmos que Paulistano e A. A. das Palmeiras tinham um público diferente do público de Corinthians e Palestra Itália. Mas, verificando os valores de mensalidade praticados por Palestra Itália e Corinthians, vemos que eram parecidos, cabendo destacar que o associado corintiano pagava uma mensalidade um pouco mais elevada que o palestrino.

Daí, entendermos os motivos que levavam a diretoria palestrina a discutir o aumento das mensalidades por ocasião da aquisição do Parque Antarctica. Provavelmente, naquele contexto, os torcedores mais pobres do Palestra Itália encontraram maior dificuldade em se associarem ao clube.

\subsection{Mais do que a caminho da zona leste, às margens do Rio Tietê.}

A trajetória corintiana está marcada pelas dificuldades de um clube de bairro que surgiu na periferia da cidade, pela atuação nos campos das várzeas e pela tentativa e êxito de ingressar no futebol oficial, o que serviu de inspiração para outras equipes varzeanas. Dos muitos problemas enfrentados pela equipe corintiana, um sempre se destacou, na medida em que demorou quase quinze anos para ser resolvido: conseguir uma sede para a prática dos esportes. As dificuldades que marcaram a trajetória corintiana estiveram presentes na trajetória das demais equipes, como reconhece um dos fundadores do Palestra Itália, Luigi Cervo:

"Enquanto se realizavam duas reuniões dançantes semanais, formava-se o quadro de futebol, cujos treinos se efetuavam num terreno acidentado, que só a

\footnotetext{
${ }^{636}$ Estatuto do Club Athlético Paulistano de 17/11/1916. Arquivo do Estado. C 10417 - 470 A.

${ }^{637}$ Estatuto da Associação Athlética das Palmeiras de novembro de 1914. Arquivo do Estado. C 10418 480.
} 
vontade dos jogadores transformou em um campo, no bairro de Vila Clementino." 638

Em geral, todos os times de futebol se defrontaram com o mesmo problema e muitas das equipes e clubes tradicionais do futebol de São Paulo sumiram na década de 1930 porque não conseguiram estabelecer-se em sedes próprias. Nesse sentido, São Paulo e Palestra Itália/Palmeiras sofreram os mesmos problemas que o Corinthians sofreu e encontraram soluções semelhantes. O Palestra Itália comprou o Parque Antarctica com o apoio dos industriais italianos da cidade e o São Paulo adquiriu sua sede na várzea do rio Tietê, local que, em nossos dias, é a sede da Portuguesa. Cabe ressaltar que a sede são-paulina no Canindé não teve qualquer relação com a sede do São Paulo da Floresta, que, como vimos, foi incorporada ao patrimônio do Clube de Regatas Tietê.

Durante as primeiras décadas do século, o rio Tietê foi área destinada pela Prefeitura para as práticas esportivas da cidade. Em 1942, os jornais da cidade discutiam a conveniência da prática da natação e outros esportes náuticos em suas águas, por conta da poluição. Naquela década, tais práticas foram proibidas e, aos poucos, a cidade perdeu seu principal rio para as grandes avenidas e para a poluição.

Mas, nas primeiras décadas do século, manter uma sede à beira do rio possibilitava o desenvolvimento de múltiplas atividades desportivas além do futebol, como a natação e o remo. Por isso, existia ali uma grande concentração de clubes desportivos, muitos dos quais exclusivos para membros da elite paulistana, que desenvolviam diversas modalidades, não apenas o futebol. E, no período abarcado, as práticas esportivas se tornaram corriqueiras nas equipes que, em sua origem, se organizaram para o futebol. Assim, o São Paulo F. C. se orgulha de sua trajetória vitoriosa no atletismo, e o mesmo acontece com o Corinthians e Germânia em suas trajetórias nos esportes náuticos, tanto que o distintivo do Corinthians possui remos, âncora e cordas, em alusão aos barcos utilizados no remo e o Germânia, desde 1920, mantinha sua sede à beira do rio Pinheiros.

Ainda hoje, um olhar atento nos permite encontrar a sede de diversos clubes na Avenida Marginal: Clube Espéria, A.A. São Paulo, Clube de Regatas Tietê, A.

\footnotetext{
${ }^{638} 26$ de agosto, a data magna do Palestra Itália. A Gazeta Esportiva. 24/08/1940. Pág. 2.
} 
Portuguesa de Desportos, Corinthians e Clube Esportivo da Penha, além do campo municipal de Baseball, denominado de Estádio Mie Nishi. ${ }^{639}$

A equipe palestrina conseguiu adquirir a principal praça de esportes da cidade, o Parque Antarctica, em 1920, com o apoio dos industriais italianos enriquecidos, mas o depoimento de Cervo sobre a sede anterior, na Vila Mariana, ao lado do que, um dia, foi o abatedouro de São Paulo, mostra que o clube também passou por dificuldades antes de obter o apoio financeiro desses industriais. No período estudado, não encontramos referências aos esportes náuticos no clube, provavelmente por conta da distância do rio Tietê e da existência de outro grande clube da comunidade ítalo-paulista nas margens do Tietê, o Clube Espéria, mas o basquete palestrino se destacava do basquete praticado nos demais clubes da cidade desde, pelo menos, a década de 1930.

Outros clubes como Tietê-São Paulo e Espéria mantinham boas equipes de natação, os clubes de elite remanescentes como Paulistano e Germânia desenvolviam suas atividades em outros esportes e os habitantes da cidade vivenciavam diversos esportes com grandes competições como a Corrida de São Silvestre, a Travessia a Nado de São Paulo, campeonatos de atletismo, de basquete e de boxe. Muitos deles, promovidos por A Gazeta desde a década de 1920.

A cidade, que se agigantava, ainda permitia o convívio de seus moradores com amplas áreas verdes, que só foram ocupadas pela especulação imobiliária na segunda metade do século XX. Mas o problema da especulação imobiliária já estava presente no cotidiano das equipes desde a implantação do futebol em São Paulo, problema esse que se juntou à crise que atingiu as equipes de futebol da cidade na década de 1930. Os clubes que adquiriram suas sedes, ou conseguiram acordos vantajosos com a Prefeitura, puderam se organizar e desenvolver suas atividades. ${ }^{640}$

\footnotetext{
${ }^{639}$ Clube Espéria: Avenida Santos Dumont, 1313. Santana. A. A. São Paulo: Rua Gal. Carmona, 131. Canindé. Clube de Regatas Tietê: Avenida Santos Dumont, 843. Canindé. Associação Portuguesa de Desportos: Rua Comendador Nestor Pereira, 33. Canindé; S.C. Corinthians Paulista: Rua São Jorge, 777. Tatuapé. Clube Esportivo da Penha: Rua Capitão João Cesário, 354. Penha. Estádio Mie Nishi: Av. Castelo Branco, 5446. Bom Retiro.

640 Prefeitura de São Paulo pode lotear área ocupada pelo Clube de Regatas Tietê. 28/10/2009. (http://g1.globo.com/Noticias/SaoPaulo/0,,MUL1357660-5605,00PREFEITURA+DE+SP+PODE+LOTEAR+AREA+OCUPADA+PELO+CLUBE+DE+REGATAS+TIE TE.html). Em nossos dias, o problema continua: o Clube de Regatas Tietê (o mesmo Tietê-São Paulo) briga na justiça para não desaparecer, pois a Prefeitura tenta retomar o terreno e transformar a área onde o clube está em um clube público sobseu próprio controle.
} 
Para os habitantes da cidade de São Paulo hoje, é difícil imaginar o rio Tietê como uma área de lazer da cidade. Mas, no período estudado, era assim que os moradores tratavam aquela região, a principal área destinada aos esportes. E, ali, o Corinthians construiu sua sede no final dos anos 1920. As fontes indicam que a transição do Corinthians do bairro do Bom Retiro para a zona leste de São Paulo foi um dos aspectos fundamentais na consolidação do imaginário do clube como o time do povo.

Um pouco antes de o Corinthians ingressar na Liga Paulista de Futebol em 1913, em uma nota publicada no Correio Paulistano sobre uma partida disputada entre o Minas Gerais, que tinha sua sede no bairro do Brás, zona leste da cidade, e Corinthians, cuja sede ficava no Bom Retiro, zona norte da cidade, verificamos a existência de grande rivalidade entre as duas equipes no contexto do futebol varzeano. A partida foi disputada no campo do Minas Gerais, que ficava na rua Miller, 57. ${ }^{641}$ A existência da rivalidade limita a hipótese de existir uma identidade entre os habitantes daquele bairro da zona leste, região fabril da cidade, com a equipe corintiana, ao menos no contexto varzeano.

Isso nos permite pensar que o imaginário corintiano, vinculado à ideia de clube dos operários ou popular, foi construído posteriormente pela trajetória muito particular, em que o time do Bom Retiro conseguiu se sobrepor a algumas rivalidades bairristas pela mudança da região da Luz para a zona leste de São Paulo. Cabe salientar que a identidade construída pelo Corinthians não eliminou o caráter popular de diversas outras equipes, e perceber que a trajetória que consolidou este imaginário teve reflexos curiosos, como a migração de alguns dos dirigentes e jogadores do Minas Gerais da década de 1910 para o Palestra Itália em anos mais tarde, caso específico de Ítalo Adami. $^{642}$

Entre 1910 e 1914, o Corinthians manteve sua sede no bairro do Bom Retiro, em rotatividade, pois, no período de quatro anos, encontramos pelo menos três endereços

\footnotetext{
${ }^{641}$ Sports. Correio Paulistano. 18/02/1916. Pág. 2.

${ }^{642}$ SANTANNA, L. O football em São Paulo. Notas crítico-biográficas dos principaes jogadores paulistas antigos e modernos. Verificar verbete do jogador Ítalo Adami. FIGUEIREDO, A. Op. Cit. Pág. 91.
} 
diferentes. Tal situação era recorrente entre os clubes paulistanos, como provam as trajetórias de Palestra Itália e Germânia no mesmo período. ${ }^{643}$

Apenas no segundo semestre de 1914, o clube realizou a transferência de sua sede social para a Rua dos Protestantes, do outro lado da Estação da Luz, na gestão de Ricardo de Oliveira, terceiro presidente do Corinthians. ${ }^{644}$ Citadini afirma que esse dirigente se caracterizava pelo espírito conciliador e diplomático, mas a mudança da sede social causou muita discórdia entre os sócios e uma grave crise financeira para o clube. ${ }^{645}$ A transferência fazia parte da estratégia da diretoria para aproximar o clube do centro de São Paulo e diminuir a identidade corintiana como a de um clube do bairro do Bom Retiro, no período em que tentava ingressar na APEA.

Provavelmente, o imaginário corintiano como clube de operários se relacione mais com o bairro de origem do que com o fato de ter sido fundado por operários, pois, como vimos, nem todos os fundadores eram operários e, durante o período estudado, a região do Bom Retiro era uma área pouco considerada pelos setores burgueses da sociedade paulistana, região marcada por indústrias e moradia dos imigrantes operários. ${ }^{646}$ Daí, a necessidade dos dirigentes corintianos de mudar a sede do clube para a região da Luz.

$\mathrm{Na}$ visão daqueles dirigentes, o Corinthians não poderia continuar no bairro do Bom Retiro porque teria, então, grandes dificuldades em ser aceito pelos clubes da APEA e se desenvolver. A estratégia de desvincular o Corinthians do bairro do Bom Retiro falhou em um primeiro momento porque os custos do aluguel eram elevados e, como a equipe não pôde atuar pelo campeonato da entidade naquele ano, não conseguiu levantar fundos extras, além dos que eram pagos pelos associados. Os problemas que o clube teve para pagar o aluguel dessa nova sede apareceram nesse período.

Surge do contexto de grandes dificuldades financeiras e invencibilidade nos gramados, a história que Neco e outros jogadores, em 1915, invadiram a sede alugada do clube para salvar os móveis que deveriam ser confiscados para o pagamento das

\footnotetext{
643 Só na década de 1920 essas duas equipes construíram suas praças desportivas nas sedes que se encontram atualmente, assim como o Corinthians. As sedes sociais foram transferidas posteriormente, na segunda metade do século XX. Na década de 1910, apenas o Paulistano tinha obtido sua praça desportiva definitiva.

${ }^{644}$ CITADINI, A. Op. Cit. Pág. 57.

${ }^{645}$ CITADINI, A. Op. Cit. Pág. 57.

${ }^{646}$ PAOLI, Maria Célia. São Paulo operária e suas imagens (1900-1940). Espaço e Debates, n. 33 . Págs. 27 - 28.
} 
dívidas geradas pelo aluguel da sede ${ }^{647}$ e que um sentimento de camaradagem entre parte desses jogadores resultou em seu envolvimento para a construção do campo corintiano da Ponte Grande, em 1918. ${ }^{648}$

Invencibilidade nos gramados, o fato de ser a primeira equipe de bairro de subúrbio a assumir um posto no campeonato principal, as dificuldades para manter o clube em funcionamento, inclusive para pagar o aluguel da primeira sede, esses fatos, contraditoriamente, fortaleceram o clube, trouxeram um número muito grande de simpatizantes entre os grupos mais pobres da cidade, permitiram a ampliação das rendas das partidas e despertaram o interesse de alguns políticos pelo clube, assim como o Palestra Itália começava a chamar a atenção dos industriais italianos. Desde então, os simpatizantes corintianos se avolumaram, e não apenas entre os trabalhadores mais pobres.

Mesmo assim, alguns jogadores partiram em 1916 para outras equipes: Bianco para o Palestra Itália; Casemiro para o Mackenzie; Peres para o Ypiranga; e Police para o Botafogo do Rio de Janeiro, como decorrência de outra contradição do episódio: o crescimento da fama dos jogadores corintianos que atuaram por outras equipes no Campeonato da APEA de 1915 fazia com que fossem cavados por equipes com melhor organização ou mais ricas. Pela primeira vez, jogadores como Neco, Amílcar, Bianco e Casemiro viraram destaques nos principais periódicos da cidade ${ }^{649}$ e, cobiçados por outras equipes de São Paulo e do Rio de Janeiro, buscaram novos rumos em suas carreiras. ${ }^{650}$ A equipe corintiana campeã de 1914 e 1916, invicta por longos meses, desde a derrota para o Torino nos amistosos organizados pela LPF, ingressou no campeonato unificado da APEA em 1917, sem o mesmo brilhantismo do Palestra Itália e do Paulistano, pois estava desfigurada pela ausência de alguns jogadores.

\footnotetext{
${ }^{647}$ UNZELTE, C. Timão. 100 anos. 100 jogos, 100 ídolos. Pág. 17.

${ }^{648}$ MAZZONI, T. História do futebol no Brasil. Pág. 125. A inauguração ocorreu com duas partidas amistosas contra o Palestra Itália.

${ }^{649}$ CITADINI, A. Op. Cit. Pág. 59. Esportazione di footballers. Fanfulla. 31/01/1918. Pág. 5.

${ }^{650}$ CORRÊA, F. P. Op. Cit. Pág. 132. O autor afirma que, naquele ano, o Botafogo do Rio de Janeiro montou uma equipe nova com jogadores oriundos do Uruguai e de São Paulo dentro de práticas profissionais que causaram grande polêmica no Rio de Janeiro. DE VANEY. História. Corinthians. Campeão do Centenário. Segundo o autor, Casimiro Gonzales (ou Casemiro) tinha olho clínico para descobrir e apurar novos jogadores. Pág. 14.
} 


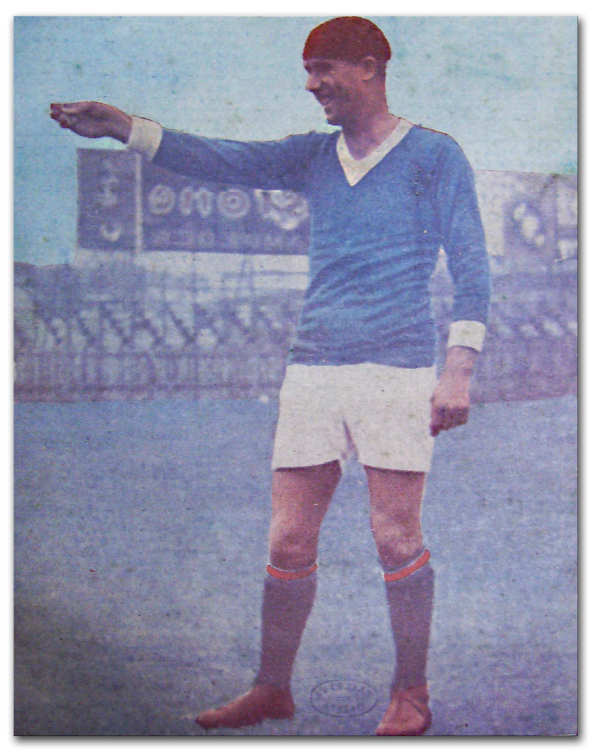

11. Spartaco Bianco como treinador do Palestra Itália, no final da década de 1920.
Um dos itens que chama a atenção nos estatutos da LPF era a exigência de todos os clubes possuírem um campo para treinamento com as dimensões oficiais. E ao que tudo indica, o campo corintiano do Bom Retiro possuía essas características. Mas, desde seu ingresso na LPF, o Corinthians nunca mais atuou no Bom Retiro. Entre 1913 e 1918, quando inaugurou uma nova praça desportiva na região da Chácara da Floresta, o Corinthians, ao atuar na cidade de São Paulo, quase sempre o fez no Parque Antarctica; apenas seis vezes no Velódromo Paulista, quatro vezes na Rua Miller, contra o Minas Gerais, e oito vezes na Chácara da Floresta. ${ }^{651}$ O Minas Gerais, outro time egresso da várzea que ingressou na LPF em 1916, ao contrário, mantinha suas atividades em seu campo original na Rua Miller, no Brás.

O campo corintiano na Ponte Grande foi inaugurado no dia 17 de março de 1918 com uma partida entre Corinthians e Palestra Itália, com público de cerca de cinco mil pessoas. ${ }^{652}$ Segundo De Vaney, o terreno foi arrendado junto à municipalidade por interferência de Alcântara Machado. ${ }^{653}$ Em 1916, a diretoria convocou reunião para discutir o problema ${ }^{654}$ e o início dos trabalhos foi anunciado no Fanfulla em outubro de 1917. ${ }^{655}$ Outra nota do Fanfulla informa que a equipe corintiana passava por um processo de renovação e destacava a estreia de Bororó, jogador que viera do Ypiranga para o Corinthians. Os festejos de inauguração se completaram na semana seguinte com

${ }^{651}$ UNZELTE, C. Almanaque do Timão. Págs. 23 a 31.

${ }^{652}$ Col primo match amichevole di quest'anno si inaugura quest'oggi Il ground Del Corinthians Paulista. Fanfulla. 17/03/1918. Pág. 7. Il Corinthians há inaugurato ieri Il ground pareggiando com La Palestra Itália per 3 a 3. Fanfulla. 18/03/1918. Pág. 5

${ }^{653}$ DE VANEY. História. Corinthians. Campeão do Centenário. Pág. 18. AMERICANO, J. São Paulo naquele tempo (1895 - 1915). Pág. 299. Ambos indicam que o futebol adquiriu importância eleitoral rapidamente na cidade de São Paulo. Penso que a atuação do vereador Alcântara Machado nesse episódio reflete essa afirmação.

${ }^{654}$ Sport Club Corinthians Paulista. Fanfulla. 27/07/1916. Pág. 5.

${ }^{655}$ Sport Club Corinthians Paulista. Fanfulla. 03/10/1917. Pág. 6. 
outra partida entre as duas equipes e o triunfo palestrino não impediu a realização de um banquete em homenagem ao Corinthians. ${ }^{656}$

Com o desenvolvimento das atividades futebolísticas e o êxito nos campeonatos de 1922, 1923 e 1924, o campo da Floresta, que ficava em terreno da Prefeitura, foi repassado ao São Bento, pois o espaço se tornara pequeno diante das necessidades do clube e demandas de sua torcida. Àquela altura, o público que assistia às partidas de futebol se agigantara e passava facilmente a casa dos trinta mil espectadores, como na partida entre Palestra e Paulistano de 1920. Em novembro de 1925, a sede de esportes ainda ficava na Chácara da Floresta, ao lado da sede da A. A. das Palmeiras, e a sede social, na rua Direita, $27,2 .^{\circ}$ andar. ${ }^{657}$

A aquisição do Parque São Jorge foi decidida no dia 2 de junho de 1926 em uma reunião que contou com a presença de 51 sócios. ${ }^{658}$ Desde novembro de 1925 , o clube criara um fundo de reserva inalienável para levantar o dinheiro necessário para a compra de um terreno destinado à construção do campo do clube. ${ }^{659}$ Inaugurado em abril de 1919, o Parque São Jorge pertencia ao Clube Sírio e ficava na Rua São Jorge, na sexta parada do trem que partia do Brás e tinha por destino o Rio de Janeiro, no bairro do Tatuapé, ${ }^{660}$ em área próxima à chácara da família Matarazzo. Foi somente então que o clube adquiriu identidade com São Jorge, considerado, atualmente, seu santo padroeiro.

Se, desde a década de 1920, a direção do clube se afastava das mãos dos sócios e jogadores de futebol, naquele mesmo período, o clube migraria em definitivo para a zona leste da cidade, região em que se concentrava boa parte do parque industrial e a maior parte do operariado da cidade. A nova geração de diretores tinha origem nas classes médias, pouco vínculo com os fundadores e buscava novos horizontes para o clube, ${ }^{661}$ inclusive o apoio de industriais que pudessem financiar o crescimento do patrimônio ou a exploração pura e simples dos jogadores de futebol, como podemos perceber dos relatos e depoimentos de Amílcar Barbuy.

\footnotetext{
${ }^{656}$ Um'altra bella palma di vittoria conquista La Palestra Itália sconfiggendo Il Corinthians per 4 a 2. Fanfulla. 25/03/1918. Pág. 6.

${ }^{657}$ Estatutos do Corinthians de novembro de 1925. Arquivo do Estado. C10417 - 479 B.

${ }^{658}$ Ata da Reunião de 02/06/1926. Arquivo do Estado. C 10417. 479 B.

${ }^{659}$ Ata da Reunião de 02/06/1926. Arquivo do Estado. C 10417. 479 B.

${ }^{660}$ I matches del parco São Jorge. La brillante inaugurazione Del ground Del Sirio. Fanfulla. 22/04/1919. Pág. 4.
}

${ }^{661}$ SALUN, A. O. Op. Cit. Pág. 71. 
Em 1930, o empresário Alfredo Schurig, que fora vice-presidente na gestão de Felipe Collona, ascendeu à posição de presidente. Fazia parte da estratégia do antigo presidente convidar membros pertencentes às boas famílias para compor a direção do clube. ${ }^{662}$ Dinheiro e prestígio se tornariam fundamentais desde então, para que alguém assumisse o comando do clube. Até hoje, o pequeno e acanhado estádio corintiano no Parque São Jorge adota o nome de Schurig, responsável pelas melhorias implantadas na sede de esportes durante sua gestão.

A Schurig se juntaram os irmãos Wladimir e Alarico Toledo Piza, médicos de certo renome na cidade. Foi sob o comando deles que foi criada a Revista do Corinthians e transformou-se o clube em clube poliesportivo, pela criação de diversos departamentos. ${ }^{663}$ Os testemunhos indicam que a atuação de Schurig no Corinthians teve características parecidas à atuação dos Matarazzo no Palestra Itália, pois, em sua gestão, o clube construiu sua praça de esportes e os estatutos do Corinthians apresentaram mudanças para diferenciar os associados que mais contribuíam financeiramente com o clube.

Nessa gestão, a equipe de futebol corintiana sofreria um desmanche em decorrência do êxodo dos jogadores de ascendência italiana e do profissionalismo. Contraditoriamente, enquanto o clube ampliava sua participação em outros esportes, construía sua sede e era dirigido por figuras da elite, o time de futebol viveu uma grande crise marcada pela debandada dos jogadores de ascendência italiana. E um empresário assumiu o comando do clube quando as fileiras futebolísticas se abriram para os jogadores negros. Com Schurig no comando, a equipe do Corinthians se consolidou, naquele momento, com o formato cometa descrito por Damatta, presente nas demais equipes que disputavam o Campeonato Paulista de Futebol. Empresários dirigentes, jogadores proletários: o imaginário profundamente identificado com as classes trabalhadoras, mas a direção nas mãos de poucos dirigentes.

Não era uma situação exclusiva do Corinthians. Os clubes que não quiseram se adaptar a essa situação abriram mão da disputa pelo Campeonato Paulista ou fecharam

\footnotetext{
${ }^{662}$ SALUN, A. O. Op. Cit. Pág. 79.

${ }^{663}$ SALUN, A. O. Op. Cit. Págs. 79 e 80. A direção do clube era constituída da seguinte maneira: Alfredo Schurig, presidente, Alarico de Toledo Piza, vice-presidente, Wladimir de Toledo Piza, secretário geral, Antonio Mauricio Romano, primeiro secretário, Matheus Gravina, segundo secretário, Avelino de Souza Sampaio, primeiro tesoureiro, Manoel de Araújo Cunha, segundo tesoureiro e Oswaldo Amaral Pacheco, diretor de futebol.
} 
suas portas. Os associados desses clubes futebolísticos, em geral, faziam parte, muitas vezes, de uma pequena classe média que se consolidou nos anos seguintes.

Quanto ao público que frequentava o Corinthians, era o que habitava aquela região fabril da cidade, a zona leste. Mas neste quesito, não havia muita diferença entre Palestra Itália, São Paulo e Corinthians, pois Água Branca, Canindé e Tatuapé apresentavam processos de ocupação muito semelhantes, na medida em que eram bairros industriais e varzeanos de São Paulo. Além do mais, os torcedores mais pobres não ingressavam nos clubes, apenas frequentavam as arquibancadas como torcedores, pois ao final do período estudado, os clubes possuíam até quinze mil associados, no máximo, quando a população da cidade já batia na casa do um milhão de habitantes.

Na década de 1940, o Corinthians comprou um terreno ao lado do Parque São Jorge que pertencia ao Guarani do Tatuapé, time de várzea que desapareceu. Como o terreno ficava do outro lado da Rua São Jorge, parte dela foi incorporada ao clube no período de construção da Avenida Marginal, junto ao rio Tietê, no acordo entre a Prefeitura e o clube, como indenização pelos prejuízos causados pela nova avenida, razão pela qual os que hoje passam em frente ao Corinthians têm a impressão de que o clube fica na Marginal do Tietê e não na rua São Jorge.

A retificação, a falta de espaço para a construção de um estádio monumental, a abertura da Avenida Marginal e o aumento da poluição do rio levaram o São Paulo F. C. a vender sua praça desportiva no Canindé na década de 1950 e a mudar-se para o bairro do Morumbi, em uma época em que o bairro não possuía as características de bairro de elite, pois era zona rural. A conversão do Morumbi em bairro de elite por intermédio de processos especulativos, na segunda metade do século XX, ajudou a distanciar ainda mais o imaginário tricolor do imaginário corintiano, na medida em que o São Paulo F. C. criou sua sede em um bairro que passara a ser sinônimo de riqueza.

Algo semelhante ocorreu com o Palestra Itália: primeiro, pela ascensão social de parcela da comunidade ítalo-paulistana, responsável em parte pela formação das classes médias paulistanas da segunda metade do século XX; depois, pela especulação imobiliária que transformou um bairro fabril, o da Água Branca, onde está a sede do 
clube, em bairro de classe média ${ }^{664}$, fatores que contribuíram para a consolidação de um imaginário palestrino distinto daquele existente entre corintianos e são-paulinos.

Esses processos não ocorreram com a sede corintiana, que, na segunda metade do século XX, foi cercada pela Avenida Marginal, próxima a um rio Tietê morto pela poluição, em uma área da cidade que demorou a ser descoberta pelo mercado imobiliário de São Paulo. Somente nos últimos vinte anos, o bairro do Tatuapé passou por processo semelhante de valorização imobiliária vivenciado por Morumbi e Água Branca. Mas a ideia de um time de pobres e trabalhadores já estava consolidada nesse período.

Na década de 1940, na mesma época em que o rio Tietê era interditado para os esportes e começava a ser retificado, ao distintivo corintiano foram incorporados os símbolos náuticos como a âncora e os remos, ${ }^{665}$ testemunhos de esportes praticados pelo clube, mas que deixaram de ser praticados por conta da poluição da água do rio.

É necessário dizermos que, se hoje os clubes possuem esses imaginários, as trajetórias de cada um deles com suas brigas internas e as disputas pelo público torcedor foram fundamentais para a formação dessas representações, memórias e identidades. A identificação de milhões de pessoas com essas trajetórias atesta que não se trata de um simples mecanismo de controle exercido pelo poder público por meio dos times de futebol, a despeito dos esforços realizados desde, pelo menos, 1904. Compreender o Corinthians e sua trajetória é compreender Palestra Itália e São Paulo e suas trajetórias, dentro de um contexto urbano muito específico, na medida em que são trajetórias com mais semelhanças do que os adeptos e dirigentes dos clubes admitem.

São três clubes fundados por uma incipiente classe média, alguns dos sócios eram imigrantes ou filhos de imigrantes, quase todos pequenos comerciantes que traziam a experiência de terem participado de outros clubes. Os três clubes mantiveram sedes provisórias e pela exploração do negócio futebol e de associação com empresários e políticos conseguiram construir as atuais sedes, abriram-se aos jogadores negros quase

\footnotetext{
${ }^{664}$ RAMOS, Aluísio Wellichan. Fragmentação do espaço da/na cidade de São Paulo. Espacialidades diversas do bairro da Água Branca. Dissertação de mestrado apresentado ao Departamento de Geografia da FFLCH-USP, 2001. Esse estudo discute como parcela do bairro da Água Branca sofreu um processo de aburguesamento, incorporado pela dinâmica imobiliária do bairro de Perdizes, bairro de elite desde o início do século XX.

${ }^{665}$ GINI, Paulo \& RODRIGUES, Rodolfo. A história das camisas dos doze maiores times do Brasil. Pág. 62. Os autores indicam que, entre 1940 e 1942, o distintivo atual foi adotado pelo clube.
} 
que simultaneamente, possuem torcedores em todos os bairros, grupos sociais e étnicos da cidade e dependem da existência desses torcedores para sobreviverem enquanto equipes de futebol. 


\section{Considerações finais}

A introdução do futebol em São Paulo, no final do século XIX e início do século $\mathrm{XX}$, tinha todas as características de um modismo estrangeiro com tudo para não ser assimilado. Assim como o ciclismo e o cricket, era uma modalidade esportiva importada por imigrantes ou filhos de imigrantes, sem qualquer vínculo aparente com as tradições culturais brasileiras. Surpreendentemente, transformou-se em um depositário de representações de todos os tipos que foram produzidas pela sociedade paulistana no século XX, por meio do qual podemos descortinar eventos e fenômenos históricos que, de outra maneira, teríamos dificuldades para compreender.

A partir do que foi dito por Nélson Rodrigues - "em futebol, o pior cego é aquele que só vê a bola", ${ }^{666}$ procuramos desvendar alguns dos múltiplos aspectos sociais que envolveram o futebol em sua fase seminal na cidade de São Paulo, na primeira metade do século $\mathrm{XX}$, e que, como disse o cronista, não estavam apenas relacionados com a bola.

A memória do futebol em São Paulo foi construída e preservada por iniciativa de alguns jornalistas, praticantes e simpatizantes do esporte. No decorrer da pesquisa, encontramos publicações da década de $1910,{ }^{667}$ fotos dos primeiros campeonatos paulistas disputados no Velódromo da família Prado - o primeiro foi disputado em 1902, figurinhas com as fotos dos jogadores que eram distribuídas em balas na década de 1920, legislação municipal tentando regulamentar a prática desde 1904, documentação produzida oficialmente pelos clubes, almanaques do futebol e muita matéria jornalística.

Há um fenômeno marcante no universo futebolístico, que é o fato de haver narrativas fantásticas em relatos deixados por aqueles que o praticaram, como jogadores, torcedores, jornalistas ou dirigentes, que testemunharam algum fato relevante

\footnotetext{
${ }^{666}$ RODRIGUES, Nélson. À sombra das chuteiras imortais; Crônicas de futebol. São Paulo, Cia. das Letras, 1993. p. 103.

${ }^{667}$ FIGUEIREDO, Antonio. História do Foot-ball em São Paulo. São Paulo, Secção de obras de $O$ Estado de S.Paulo, 1918 e SANT'ANNA, Leopoldo. O football em São Paulo. Notas critico biographicas dos principaes jogadores paulistas antigos e modernos. São Paulo, Typographia Piratininga, 1918
} 
ou apenas ouviram falar. Essas narrativas circulam ainda hoje entre os torcedores dos clubes, transmitidas de geração em geração, e servem de suporte ideológico às escolhas, rivalidades e simpatias de cada torcedor por uma dada equipe. Elas versam sobre diversos aspectos e temas do esporte desde a introdução do futebol em São Paulo: os mitos de fundação de cada clube, o processo de popularização de cada um deles e suas relações com outras demandas sociais, políticas e econômicas. ${ }^{668}$

As publicações dos clubes trataram de construir, consolidar ou difundir algumas dessas histórias; outras surgiram e se agigantaram por iniciativa dos torcedores, transformando-se em mitos, processo este que não é nosso foco central de análise. As primeiras publicações organizadas pelos clubes surgiram na década de 1930, quando o futebol começou a se profissionalizar. Todas traziam o espaço dedicado à história de cada clube. Em 1933, por exemplo, o Corinthians lançou o primeiro volume da Revista do Corinthians, retomada com grande força, no final dos anos 1940, com a coluna Memória Corintiana, na qual eram contados fatos considerados relevantes pela diretoria do clube naquele momento.

Pelo exposto, podemos pensar que essas publicações construíram tradições que se assemelham aos eventos descritos por Eric Hobsbawn e Terence Ranger sobre as tradições inventadas. ${ }^{669}$ Elas dizem respeito às demandas internas dos clubes ou relacionadas à concorrência com os adversários nas disputas dos campeonatos. Entretanto, a compreensão de como cada clube construiu sua própria memória não esgota um outro aspecto central da pesquisa: o que essas narrativas dizem sobre o

\footnotetext{
${ }^{668}$ E exemplo marcante do que descrevemos, é o relato que circula na Sociedade Esportiva Palmeiras e entre boa parte de sua torcida: que, em 1942, os diretores e torcedores do São Paulo Futebol Clube tentaram tomar a sede do então Palestra Itália, com base nas leis de segurança nacional criadas pelo Governo Vargas, que permitiam a nacionalização dos bens italianos, japoneses e alemães no contexto da 2. ${ }^{a}$ Guerra Mundial, e foram rechaçados a pedradas por torcedores palestrinosna Rua Turiaçu, Água Branca/Pompeia, onde fica a entrada da sede palmeirense. Na final do Campeonato Paulista de 2008, esse assunto foi reavivado pela diretoria palmeirense no episódio que está sendo investigado pela polícia: incidente ocorrido na partida entre São Paulo e Palmeiras pela semifinal do Campeonato, quando um spray com gás pimenta foi disparado dentro do vestiário são-paulino (as duas equipes se acusam mutuamente pelo uso do gás). As fontes indicam que a diretoria tricolor não tentou tomar do Palmeiras o Parque Antarctica, na medida em que já possuía sede própria no Canindé, e asseguram que, naquele contexto, em uma partida de juniores realizada no Parque Antarctica, alguns dias antes da mudança de nome do Palestra para Palmeiras e da grande final do campeonato de 1942, torcedores, dirigentes e jogadores das duas equipes se enfrentaram em uma briga campal lamentada pela $A$ Gazeta. Semeando ventos. A Gazeta. 04/09/1942. Pág. 8.
}

${ }^{669}$ HOBSBAWN, Eric J. e RANGER, Terence. A invenção das tradições. São Paulo, Paz e Terra, 1997. 
cotidiano da cidade e como permitiram a tantas pessoas se identificarem com elas, a ponto de as transformarem em mitos? Seria apenas um exercício de dominação dos grupos dirigentes da cidade, partícipes dos clubes como paredros/cartolas? ${ }^{670}$ Será que não poderíamos descortinar aspectos importantes da sociedade paulistana da primeira metade do século XX por meio dessas narrativas?

As fontes pesquisadas sugerem que o período histórico estudado foi marcado por fortes conflitos sociais, políticos e econômicos de toda ordem que repercutiram na construção das identidades dos torcedores das três equipes, tornando as respectivas trajetórias muito parecidas, quase paralelas.

Na pesquisa, descobrimos diversos fenômenos interessantes. Enquanto os clubes que mantinham os três principais times de futebol da cidade se converteram em associações fortemente hierarquizadas, controladas normalmente por membros da elite paulistana, frequentadas em sua maior parte por membros das classes médias, com os grupos pobres restritos às arquibancadas como público ou aos campos de futebol como jogadores, suas representações se consolidaram como simulacros dos diversos conflitos que marcaram o cotidiano dos habitantes de São Paulo, no período estudado, consonantes os grupos sociais mais representativos da cidade. A luta de classes e as questões étnicas talvez sejam os grandes exemplos daquilo a que nos referimos.

As trajetórias das três equipes, vasculhadas na pesquisa, mostram origens semelhantes. No entanto, os simpatizantes do São Paulo Futebol Clube cristalizaram uma identidade vinculada a ideias como elitismo e herança do Paulistano; os simpatizantes da Sociedade Esportiva Palmeiras cristalizaram a ascendência italiana e os simpatizantes do Sport Club Corinthians Paulista cristalizaram a identidade de time dos pobres. Percebemos que algumas dessas identidades, como a palmeirense, foram forjadas por representações criadas como tentativas de esvaziar movimentos contestatórios protagonizados pelos anarquistas e que marcavam a comunidade ítalopaulista entre a eclosão da Primeira Guerra Mundial e a década de 1920. No caso sãopaulino, parece evidente que a identidade de clube de elite é o resultado de uma estratégia para arregimentar os simpatizantes do C. A. Paulistano, da A.A. das

\footnotetext{
${ }^{670}$ Na primeira metade do século XX, os dirigentes dos clubes eram chamados de paredros, assim como hoje são chamados de cartolas.
} 
Palmeiras e do São Paulo da Floresta, nas décadas de 1930 e 1940, quando tais clubes desistiram de manter times de futebol.

As fontes apontam que os principais clubes de futebol foram alvo do interesse das elites da cidade desde a primeira década do século, mesmo quando seus fundadores pertencessem às classes médias. Os grandes industriais italianos financiaram o Palestra Itália, assim como o vereador Alcântara Machado e os empresários de origem suíça ou espanhola ajudaram o Corinthians, e Ademar de Barros e outros empresários brasileiros ajudaram o São Paulo.

Também verificamos que o futebol foi apropriado por todos os grupos sociais da cidade ainda na virada do século XIX, como atesta a carta de Charles Miller à sua escola na Inglaterra. ${ }^{671} \mathrm{~A}$ ideia de que o futebol era um esporte de elite e que só se popularizou a partir da década de 1910 não procede e tudo indica que quanto mais importante se tornava para a população da cidade, mediante diversas ressignificações, maiores interesses despertava, inclusive o da geração de lucro por meio da organização de campeonatos.

Nesse contexto, não faz sentido falar em profissionalização apenas na década de 1930. Em um sistema de entretenimento competitivo como um campeonato, a especialização dos envolvidos e sua consequente profissionalização decorrem das exigências de um público que paga ingressos e quer assistir a espetáculos excitantes. Os relatos de falso amadorismo remontam aos primeiros campeonatos, assim como as disputas se relacionavam com o controle dos espetáculos, e nada foi provocado por problemas entre amadores e profissionais, ricos e pobres, como sugere uma memória com o viés da elite.

Os clubes da elite de São Paulo desistiram do futebol ou faliram na década de 1930 como consequência da crise que se abateu sobre o futebol brasileiro quando os clubes italianos, argentinos e uruguaios começaram a contratar os jogadores brasileiros como profissionais, no início dos anos 1930. E desde 1928, os jogadores lutavam pelo reconhecimento da profissão de jogador de futebol e pela aquisição de direitos trabalhistas mínimos, como salário. Dessa forma, CBD, ligas estaduais e os clubes foram obrigados a adotar o regime profissional, pois, até então, as relações entre eles e

\footnotetext{
${ }^{671}$ Apud HAMILTON, Aidan. Um jogo inteiramente diferente! Futebol: A maestria brasileira de um legado britânico. Op. Cit. A carta está publicada, na íntegra, no início do livro.
} 
seus jogadores eram semelhantes às relações de empresas que exploram seus empregados até o limite, pagam péssimos ordenados, precarizam as condições de vida dessas pessoas e promovem a proletarização. Para os clubes, tal situação foi muito interessante, pois permitiu a construção dos respectivos patrimônios. O patrimônio dos clubes de São Paulo foi construído à custa dos esforços desses jogadores até os anos 1930, como percebeu o jogador Amílcar Barbuy.

Outro fenômeno interessante que podemos apontar é que o futebol se forjou como um importante espaço de mediação social da cidade de São Paulo no período estudado. Os mais diversos grupos sociais se encontravam nos campos oficiais ou varzeanos, nas arquibancadas improvisadas das antigas praças de esporte ou no Estádio Municipal, daí a consolidação de forte ritualização nas arquibancadas a partir da década de 1940. Claro que não eram encontros pacíficos, a presença policial nas arquibancadas ocorria desde da década de 1910, assim como as brigas entre torcedores, que já ocorriam nas dependências do Velódromo Paulista.

A ideia de que as autoridades públicas se preocuparam com o futebol apenas na década de 1930 pode ser contestada por meio desta pesquisa, pois, desde 1904, a Prefeitura de São Paulo criou leis para regulamentar sua prática e tentou concentrar seus praticantes em determinadas áreas da cidade, por meio de proibições e da construção de espaços específicos para sua prática, como as margens do rio Tietê. O Estádio Municipal do Pacaembu seria a maior dessas iniciativas, em plena ditadura Vargas, para o estabelecimento das redes de controle sobre os praticantes de futebol da cidade. Tratava-se de um espaço amplo que comportava pouco mais de setenta mil torcedores em uma época em que a população da cidade estava um pouco acima de um milhão de habitantes. Cerca de 5\% da população de São Paulo assistiu à estreia de Leônidas da Silva em 1942.

Outra questão que apareceu no decorrer da pesquisa, colocada por alguns autores, ${ }^{672}$ diz respeito à textualidade simbólica das partidas de futebol, já que nelas existem ritualização e performatividade que foram construídas no decorrer do século XX na cidade de São Paulo - na Europa, o processo ocorreu no último quartel do século

\footnotetext{
672 DA MATTA, Roberto. Op. Cit. CONNERTON, Paul. Como as sociedades lembram. Oeiras, Celta Editora. 1993. CORBIN, Alain; COURTINE, Jean-Jacques e VIGARELLO, Georges (orgs.). História do Corpo - Vol. 3. As mutações do olhar: O século XX. Petrópolis. Vozes. 2008; DAMO, Arlei Sander. Do dom à profissão. A formação de futebolistas no Brasil e na França. São Paulo. Hucitec. 2007; SAHLINS, Marshall. Cultura e razão prática. Rio de janeiro. Zahar. 2003.
} 
XIX -, e que permitem conhecer, por meio da gestualidade, dos movimentos e das atitudes dos corpos dentro dos estádios ou nos campos, diversas dimensões culturais da sociedade paulistana, pois o ritual não é apenas uma maneira alternativa de exprimir certas crenças, mas, muitas vezes, é a única maneira, na medida em que a execução de um ritual expõe e especifica a relação que prevalece entre os atores envolvidos e aquilo que executam.

Sugerimos que a disputa de uma partida de futebol dá forma a um desejo de comunidade e desperta diversos dispositivos mnemônicos que estão ocultos em outros espaços sociais por diversos fatores. Trata-se de representar e recordar a própria identidade antes, durante e depois do jogo, contando-a em uma metanarrativa que é mais que a história que se conta e sobre a qual se reflete, pois é um culto encenado, uma "performance", nos campos e também nas arquibancadas, em que os participantes torcedores, jornalistas, dirigentes esportivos e jogadores, devem ter instrumental cognoscível para compreender e, também, devem estar habituados ou ser competentes para praticar. Se não dominam a prática com a bola como os jogadores, todos os torcedores conhecem as jogadas, os termos, as gírias e os dribles, como se comportar dentro e fora do estádio, como torcer e incentivar o time com o qual simpatiza.

Essas convenções corporais foram historicamente construídas, eram técnicas imbuídas de valores morais que só foram esquecidas como máximas na medida em que foram memorizadas como hábitos. Tal como as cerimônias, as convenções e as técnicas do corpo existem ao longo de um espectro de possibilidades que vão do mais ou menos formal ao mais ou menos informal, ${ }^{673}$ todas elas envolviam e envolvem, em termos variáveis, a memória cognitiva.

Em toda exibição cerimonial - e o futebol é uma exibição cerimonial -, os atores são recordados de algo com conteúdo cognitivo. Mas é também pelo ato da representação que recordam. A execução adequada de movimentos não só recorda os sistemas de classificação que o grupo acha importante, como também exige o exercício da memória-hábito. As representações são tomadas como certas, na medida em que forem recordadas como hábitos. Aquilo que é representado ganha força, na medida em que é algo a que os atores estão habituados, ${ }^{674}$ que consolida a própria identidade em

\footnotetext{
${ }^{673}$ CONNERTON, Paul. Como as sociedades lembram. Pág. 100.

${ }^{674}$ CONNERTON, Paul. Como as sociedades lembram. Pág. 105.
} 
distinção à identidade de outros grupos sociais. Daí, a importância dos dribles e gingas protagonizados pelos jogadores nos gramados. Os torcedores brasileiros raramente elogiam jogadas de força física, mas enaltecem a habilidade individual dos jogadores dribladores e inventivos como Leônidas, autor de inúmeras bicicletas, jogada em que o jogador chuta a bola para trás, com o corpo no ar e as pernas acima do tronco. Os próprios zagueiros, quando vítimas desses dribles, compreendem o simbolismo envolvido e se irritam, não raras vezes, gerando brigas dentro de campo.

Diante dos testemunhos encontrados na pesquisa, sugerimos que o futebol permite perceber a rica contribuição daquela população que aqui habitava antes do ciclo da imigração às práticas culturais vigentes atualmente na cidade, população que foi silenciada no decorrer do século XX por iniciativas oficiais, como a demolição da Igreja de Nossa Senhora do Rosário e de outros marcos geográficos utilizados, ou mesmo por iniciativas informais, por meio da construção da memória da cidade e seus mitos, mas que permaneceu viva nos gramados de futebol da cidade por todo o período estudado.

A existência de clubes de futebol fundados e mantidos por jovens negros permite inferir que esta parcela da população paulistana participou ativamente do processo de ressignificação do futebol na cidade e na construção das representações que circulam nos meios futebolísticos ainda hoje. O aprofundamento desta pesquisa poderá responder a questões inquietantes sobre o papel da população negra de São Paulo, ao longo do período estudado, no que diz respeito ao processo modernizador implantado pelas elites brancas.

Também se deve aprofundar o estudo da trajetória dos cronistas e jornalistas que se dedicaram à construção das representações que apresentamos e discutimos neste trabalho, como esses atores se relacionavam com as demandas políticas, econômicas e sociais dos habitantes de São Paulo e quais suportes utilizaram para produzir suas narrativas. Mas as evidências sugerem que, se por um lado as narrativas mnemônicas dos grupos mais pobres não foram contempladas por esta tradição escrita, por outro permanecem ainda hoje resguardadas no talento dos melhores jogadores das equipes profissionais. 


\section{Fontes}

I - Periódicos

- A Gazeta Esportiva - acervo da Federação Paulista de Futebol. Anos de 1928, 1929 e 1930.

- A Gazeta - acervo do Arquivo do Estado de São Paulo. Anos 1917, 1918, 1919, 1920 e de 1930 a 1942.

- O Estado de S. Paulo - acervo do Arquivo do Estado de São Paulo. Anos 1916, 1917, 1918, 1919 e 1920.

- Fanfulla - CAPH "Sérgio Buarque de Holanda". Anos 1914, 1915, 1916, 1917, 1918, 1919 e 1920.

- Série "DNA Paulistano", publicada pela Folha de S.Paulo entre agosto e setembro de 2008.

- Carta de Charles Miller publicada na Revista da Banister Court School vol.III, ${ }^{\circ}$. 31, março de 1904. Tradução brasileira no livro de HAMILTON, Aidan. Um jogo inteiramente diferente! Futebol: A maestria brasileira de um legado britânico. Rio de Janeiro, Gryphus, 2001.

- The Sportsman - The British Library. Ano de 1910.

II - Revistas ou publicações dos clubes pesquisados.

- Coleção de Revistas do Sport Club Corinthians Paulista. Revista publicada semestralmente pelo clube. (Coleção particular do jornalista Celso Unzelte). Anos de 1933, 1949, 1950, 1951, 1952, 1953, 1954, 1955, 1956, 1957, 1958, $1959,1960$.

- Corinthians. Campeão dos Centenários. Edição publicada pelo clube em 1964.

- Cinqüentenário do Esporte Clube Pinheiros. Edição celebrativa publicada pelo clube em 1948. 
- MAZZONI, Thomaz; PERUZZI, Milton; GUIMARÃES, Tyrso Fernandes. No tempo do "Palestra é Palestra". Álbum Comemorativo Jubileu de Ouro da Sociedade Esportiva Palmeiras. São Paulo, TM Publicidade, 1964.

- PIMENTEL, Odair \& PENNA, Maysa. São Paulo Futebol Clube (1935 - 1980). São Paulo, Mauro Ivan Marketing Editorial, 1981.

III - Acervo do IEB/Coleção Caio Prado Jr.

- Revista A Bicycleta de 21/06/1896. Relato sobre o Velódromo Paulista.

- Ilustração patrocinada pelo Veloce Club Olímpico Paulista publicada na Revista A Bohemia $-\mathrm{n}^{\circ} 5$, de julho de 1896.

- Recorte do Diário da Noite (29/12/1930) que retrata e relata como se deu a inauguração do Velódromo Paulista, no dia 21 de junho de 1896.

IV - Legislação e Dados Municipais

- Relatório de Realizações de Governo do Senhor Antonio da Silva Prado, prefeito de São Paulo entre 1899 e 1910, entregue à Câmara Municipal em 1910.

- Relatório de Realizações de Governo do Senhor Raymundo Duprat, prefeito de São Paulo entre 1911 e 1914, entregue à Câmara Municipal em 1914.

- Relatório de Realizações de Governo do Senhor Washington Luis Pereira de Sousa, prefeito de São Paulo entre 1915 e 1918, entregue à Câmara Municipal em 1918.

- Relatório de Realizações de Governo do Senhor Firmínio de Moraes Pinto, prefeito de São Paulo entre 1919 e 1924, entregue à Câmara Municipal em 1924.

- Censos municipais de 1890, 1940 e 2000. http://sempla.prefeitura.sp.gov.br/historico/

V - Livros 
- FIGUEIREDO, Antonio. História do Football em São Paulo. São Paulo, O Estado de São Paulo, 1918.

- Federação Paulista de Futebol. Concurso Literário. 60 anos de futebol no Brasil (1894-1954). São Paulo, $1956^{675}$.

- MAZZONI, Thomaz. Problemas e aspectos do nosso futebol. São Paulo, 1939.

- ---------------------História do futebol no Brasil (1894-1950). São Paulo, 1950.

- ------------------------Álbum histórico da Sociedade Esportiva Palmeiras. Campeão mundial de 1951. São Paulo, Sociedade Esportiva Palmeiras, 1952.

- SANT'ANNA, Leopoldo. O football em São Paulo. Notas crítico-biográficas dos principaes jogadores paulistas antigos e modernos. São Paulo, Typographia Piratininga, 1918.

Paulo, Instituto Ana Rosa, 1925.

${ }^{675}$ A comissão julgadora era formada por Caetano Carlos Paioli, Delfino Facchina e Leopoldo Sant'Anna. 


\section{Bibliografia}

ANDERSON, Benedict. Comunidades Imaginadas. São Paulo, Cia. das Letras, 2008.

AMERICANO, Jorge. São Paulo naquele tempo (1895 - 1915). São Paulo, Saraiva, 1957.

-São Paulo nesse tempo (1915-1935). São Paulo,

Melhoramentos, 1962.

ANTUNES, Fátima M. R. F. Futebol de fábrica em São Paulo. São Paulo, Dissertação de mestrado, FFLCH-USP, 1992.

Com brasileiro, não há quem possa! Futebol $e$ identidade nacional em José Lins do Rego, Mário Filho e Nelson Rodrigues. São Paulo, Unesp, 2004.

“"O futebol na Light \& Power de São Paulo”.

Pesquisa de Campo, 3 e 4, Rio de Janeiro, 1996.

Do velódromo ao Pacaembu: o movimento esportivo em São Paulo e a trajetória do futebol, de esporte de elite a paixão nacional. Revista do Departamento de Patrimônio Histórico, São Paulo, ano v, n.5, jan. 1998, pp.88-95.

AQUINO, Rubem Santos Leão. Futebol. Uma paixão nacional. Rio de Janeiro, Jorge Zahar, 2002.

ARAÚJO, José Renato de Campos. Imigração e futebol. O caso Palestra Itália. São Paulo, Sumaré, 2000.

ARÓSTEGUI, J. A pesquisa histórica. Teoria e método. Bauru, EDUSC, 2001.

BELLUZZO, Ana Maria de Moraes. Voltolino e as raízes do modernismo. São Paulo, Marco Zero, 1992.

BERTONHA, João Fábio. O fascismo e os imigrantes italianos no Brasil. Porto Alegre, EDIPUCRS, 2001.

Sob a sombra de Mussolini. Os italianos de São Paulo e a luta contra o fascismo. São Paulo, Annablume, 1999.

-Os italianos. São Paulo, Contexto, 2005. 
BESSA, Virgínia. Um bocadinho de cada coisa. Trajetória e obra de Pixinguinha.

História e música popular no Brasil dos anos 20 e 30. Dissertação de mestrado em História Social apresentada ao Depto. de História da FFLCH - USP, 2006.

BOSI, Ecléa. Memória e sociedade. Lembranças de velhos. São Paulo, Cia. das Letras, 1994.

BRANDÃO, Ignácio de Loyola. São Paulo Futebol Clube. A saga de um campeão. São Paulo, Dorea Books and Art, 1996.

Club Athetico Paulistano. São Paulo, DBA, 1995.

BRUNO, Ernani Silva. História e tradições da cidade de São Paulo. Rio de Janeiro, José Olympio, 1954, Vol. III.

BUCHMANN, Ernani. Quando o futebol andava de trem. Memória dos times ferroviários brasileiros. Curitiba, Imprensa Oficial, 2002.

BURKE, Peter. A história social dos clubes. Folha de S. Paulo, 24/02/2002.

CALDAS, Waldenir. O pontapé inicial. Memória do futebol brasileiro (1893-1933). São Paulo, Ibrasa, 1990.

CARELLI, Mário. Carcamanos \& Comendadores. São Paulo, Ática, 1985.

CARVALHO, Gustavo Longhi. Milani. O artilheiro aviador. São Paulo, Faccamp, 2007.

CENNI, Franco. Os italianos no Brasil. São Paulo, EDUSP, 2003.

CITADINI, Antonio Roque. Neco. O primeiro ídolo. São Paulo, Geração, 2003.

CHARTIER, Roger. História Cultural. Entre práticas e representações. Bertrand Brasil e Difel, Rio de Janeiro, 1988.

CORBIN, Alain; COURTINE, Jean-Jacques e VIGARELLO, Georges (orgs.). História do Corpo - vol. 3. As mutações do olhar: O século XX. Petrópolis, Vozes, 2008.

CORREIA, Floriano Peixoto. Grandezas e misérias do nosso futebol. Rio de Janeiro, Hermano Editores, 1933.

COUTO, Ronaldo Costa. Matarazzo. A travessia. São Paulo, Editora Planeta do Brasil, 2003.

-Matarazzo. Colosso Brasileiro. São Paulo, Editora

Planeta do Brasil, 2004. 
CRONIN, Mike e MAYALL, David. Sporting Nationalisms. Identity, Ethnicity, Imigration and Assimilation. Londres, F. Cass, 1989.

CUNHA, Odir. Quem duvida da Imprensa? São Paulo, 21/04/2008. Sítio da internet do

Observatório $d a$

Imprensa.

http://observatoriodaimprensa.com.br/artigos.asp?cod=534JDB003

DA MATTA, Roberto. Universo do futebol. Rio de Janeiro, Pinakotheke, 1982.

Carnavais, Malandros e Heróis. Para uma sociologia do dilema brasileiro. Rio de Janeiro, Rocco, 1997.

Em torno da dialética entre igualdade e hierarquia: Notas sobre as imagens e representações dos Jogos Olímpicos e do futebol no Brasil. Antropolítica; Revista contemporânea de antropologia e ciência política. Niterói, EDUFF, $n^{\circ} 14,1995$, pp17-39.

DAMO, Arlei Sander. Do dom à profissão. Uma etnografia do futebol espetáculo a partir da formação de jogadores no Brasil e na França. Porto Alegre, Tese de doutorado, PPGAS/UFRGS, 2005.

DEL PRIORE, Mary \& MELO, Victor Andrade de. História do esporte no Brasil. São Paulo, Unesp, 2009.

FERREIRA, João Fernando. A construção do Pacaembu. São Paulo, Paz e Terra, 2008.

FIGUEIREDO, Antonio. História do Foot-ball em São Paulo. São Paulo, Secção de obras de O Estado de S.Paulo, 1918.

-Memórias de um jornalista. São Paulo, Edição Unitas, 1933.

FLORENZANO, José Paulo. Afonsinho \& Edmundo. A rebeldia no futebol brasileiro. São Paulo, Musa Editora, 1998.

A democracia corinthiana. Prática de libertação

no futebol brasileiro. São Paulo, Tese de doutorado, Departamento de antropologia/PUC-SP, 2003.

FRANZINI, Fábio. Corações na ponta das chuteiras. Capítulos iniciais da história do Futebol Brasileiro (1919 - 1938). São Paulo, DPA, 2003. 
--Futebol é coisa pra macho? Pequeno esboço para a história das mulheres no país do futebol. Antropologia do esporte. As múltiplas dimensões de uma prática moderna. Curitiba, IV Reunião de Antropologia do Mercosul, 2001.

FREYRE, Gilberto. Interpretação do Brasil. Rio de Janeiro, José Olympio, 1947. -Sociologia. 4a Ed. Rio de Janeiro, José Olympio, 1967.

GAFFNEY, Christopher; MASCARENHAS, Gilmar. O estádio de futebol como espaço disciplinar. Seminário Internacional Michel Foucalt - Perspectivas. Florianópolis, UFSC, 2004.

GIACOMINI, Conrado. São Paulo. Dentre os Grandes, és o primeiro. São Paulo, Ediouro, 2005.

GINI, Paulo \& RODRIGUES, Rodolfo. A história das camisas dos doze maiores times do Brasil. São Paulo, Panda Books, 2009.

GLEZER, Raquel. Chão de terra e outros ensaios sobre São Paulo. São Paulo, Alameda Editorial, 2007.

GONÇALVES Jr., René Duarte. Friedenreich e a Reinvenção de São Paulo. O futebol e a Vitória na Fundação da Metrópole. São Paulo, Dissertação de mestrado apresentado ao Departamento de História da FFLCH-USP, 2008.

HAMILTON, Aidan. Um jogo inteiramente diferente! Futebol: A maestria brasileira de um legado britânico. Rio de Janeiro, Gryphus, 2001.

HELENA Jr., Alberto. Palmeiras, a eterna academia. São Paulo, DBA, 1996.

HOBSBAWN, Eric J. Mundos do trabalho. Novos estudos sobre história operária. Rio de Janeiro, Paz e Terra, 1984.

-História social do Jazz. Rio de Janeiro, Paz e Terra, 1991. -A Era dos extremos. São Paulo, Cia.das Letras, 1997. --A Era dos impérios. Rio de Janeiro, Paz e Terra, 1998. $5^{\text {a }}$ Edição.

HOBSBAWN, Eric J. \& RANGER, Terence (orgs.). A invenção das tradições. Rio de Janeiro, Paz e Terra, 1997.

IANNI, Constantino. Homens sem paz. Os conflitos e os bastidores da imigração italiana. São Paulo, DIFEL, 1963.

KFOURI, Juca. Corinthians, paixão e glória. São Paulo, DBA, 1996. 
--Por que não desisto. Futebol, dinheiro e política. São Paulo, DISAL, 2009.

LE GOFF, Jacques. História e memória. Campinas, Editora da Universidade Estadual de Campinas, 1990.

LOPREATO, Christina da Silva Roquette. A semana trágica. A greve anarquista de 1917. São Paulo, Museu da Imigração, 1997.

O espírito da revolta. A greve geral anarquista de 1917. São Paulo, Annablume/Fapesp, 2000.

MACHADO, Antonio de Alcântara. Novelas paulistanas. Brás, Bexiga e Barra Funda, Laranja da China, Mana Maria e Contos Avulsos. 4ª Edição. Rio de janeiro, José Olympio, 1976.

MARAM, Sheldom Leslie. Anarquistas, imigrantes e o movimento operário brasileiro (1890 - 1920). Rio de Janeiro, Paz e Terra, 1979.

MARINS, Paulo César Garcez. Habitação e vizinhança. Limites da privacidade no surgimento das metrópoles brasileiras. (In) SEVCENKO, N. (org.). História da Vida Privada no Brasil. Vol. III. República. Da Belle Epóque a Era do Rádio. São Paulo, Cia. Das Letras, 1998.

MARQUES, José Carlos. O futebol em Nelson Rodrigues. O óbvio ululante, o Sobrenatural de Almeida e outros temas. São Paulo, EDUC/FAPESP, 2003.

MARTINS, Antonio Egídio. São Paulo antigo (1554-1910). São Paulo, Paz e Terra, 2003.

MARTINS, José de Souza. Conde Matarazzo, o empresário e a empresa. Estudo de sociologia do desenvolvimento. São Paulo, Hucitec, 1974.

MARTORELli, Fausto e SILVA, Katya Marcus da. Palmeiras. Minha eterna paixão. São Paulo, Casa do novo autor, 2004.

MASCARENHAS, Gilmar. Várzeas, operários e futebol. Uma outra geografia. Revista Geographia nº 8, Jul/Dez de 2008, Rio de Janeiro, Publicação semestral do programa de pós-graduação em Geografia da Universidade Federal Fluminense.

MAZZONI, Thomaz. Almanaque Esportivo de 1928. São Paulo, Ferrari \& Losasso Empreendimentos Gráficos, 1928.

Problemas e aspectos do nosso futebol. São Paulo, 1939.

História do futebol no Brasil (1894-1950). São Paulo, 1950. 
mundial de 1951. São Paulo, 1952.

MAZZONI, Thomaz; PERUZZI, Milton; GUIMARÃES, Tyrso Fernandes. No tempo do "Palestra é Palestra". Álbum Comemorativo Jubileu de Ouro da Sociedade Esportiva Palmeiras. São Paulo, TM Publicidade, 1964.

MILLS, John. Charles Miller. O pai do futebol brasileiro. São Paulo, Panda Books, 2005.

Charles William Miller. Memoriam S.P.A.C(1894-1994). São Paulo,

Price Waterhouse, 1996.

MORBIO, Antonio Carlos. Sempre Palmeiras. São Paulo, Sketch Design, 2000.

MORAES, José Geraldo da Vinci de. Metrópole em sinfonia. História, cultura e música popular na São Paulo dos anos 30. São Paulo, Estação Liberdade, 2000.

NAPOLEÃO, Antonio Carlos. Palmeiras X Corinthians. Uma história de rivalidade. Rio de Janeiro, MAUAD, 2001.

NEGREIROS, Plínio José Labriola de Campos. Resistência e rendição. A gênese do Sport Club Corinthians Paulista e o futebol oficial de São Paulo (1910-1916). São Paulo, Dissertação de mestrado apresentada ao Programa de Estudos Pós-Graduados em História da PUC, 1992.

A nação entra em campo. Futebol nos anos 30 e 40. São Paulo, Tese de doutorado, Departamento de História, PUCSP, 1998.

NICOLINI, Henrique. Tietê. O rio dos esportes. São Paulo, Phorte Editora, 2001.

PAOLI, Maria Célia. São Paulo operária e suas imagens (1900-1940). Espaço e debate, Revista de Estudos Regionais e Urbanos, n³3, 1981.

PASSOS, Maria Lúcia Perrone \& EMÍDIO, Teresa. Desenhando São Paulo. Mapas e literatura. São Paulo, Senac/Imprensa Oficial, 2009.

PIMENTEL, Odair \& PENNA, Maysa. São Paulo Futebol Clube (1935 - 1980). São Paulo, Mauro Ivan Marketing Editorial, 1981.

PINTO, Maria Inez Machado Borges. Cotidiano e sobrevivência. A vida do trabalhador pobre na cidade de São Paulo (1890-1914). São Paulo, Edusp/Fapesp, 1994. 
RAMOS, Aluísio Wellichan. Fragmentação do espaço da/na cidade de São Paulo. Espacialidades diversas do bairro da Água Branca. São Paulo. Dissertação de mestrado apresentado ao Departamento de Geografia da FFLCH-USP, 2001.

REALI, Ebe. Brás, Pinheiro, Jardins. Três bairros, três mundos. São Paulo, Edusp, 1982.

REIS, Letícia Vidor de Sousa. Negros e brancos no jogo da capoeira. A reinvenção da tradição. Dissertação de mestrado em Ciência Social apresentada à FFLCH USP, 1993.

-Na batucada da vida. Samba e política no Rio de Janeiro (1889-1930). Tese de doutorado apresentada ao programa de pós-graduação em Antropologia Social da USP, 1999.

REIS Filho, Nestor Goulart. Parques na Primeira República. Jornal da Tarde. 23.6.1990, pág. 6

--Futebol e os velódromos. Jornal da Tarde,

09.06.1990, pág. 6.

RIBAS, Mário Graco. História do Esporte Clube Pinheiros. São Paulo, ECP, 1968.

RIBEIRO, Rubens. O caminho da bola. Cem anos de história da Federação Paulista de Futebol. Vol. I (1902-1952). São Paulo, CNB Comunicação e Marketing, 2000.

RODRIGUES Filho, Mário. O negro no futebol brasileiro. Petrópolis, Firmo, 1994.

RODRIGUES, Nélson. À sombra das chuteiras imortais. São Paulo, Cia. das Letras, 1993.

A pátria em chuteiras. Novas crônicas de futebol. São Paulo,

Cia. das Letras, 1994.

RODRIGUES FILHO, Nélson. Lima Barreto: jogando contra o futebol. Pesquisa de campo; Brasil: futebol tetracampeão do mundo. Rio de Janeiro, Depto. Cultural da UERJ, nº1, 1995, pp. 43-44.

ROLNIK, Raquel. A cidade e a lei. Legislação, política urbana e territórios na cidade de São Paulo. Fapesp/Studio Nobel, São Paulo, 1997.

ROSENFELD, Anatol. Negro, macumba e futebol. São Paulo, EDUSP/Perspectiva, 1993. 
SAHLINS, Marshall. História e cultura. Apologias a Tucidides. Jorge Zahar, Rio de Janeiro, 2006.

Cultura e razão prática. Jorge Zahar, Rio de Janeiro, 2003.

SALUN, Alfredo Oscar. Palestra Itália e Corinthians. Quinta Coluna ou Tudo

Buona Gente? Tese de Doutorado apresentada ao Departamento de História da FFLCH-USP, 2007.

SANDER, Roberto. Anos 40. Viagem à década sem Copa. Rio de Janeiro, Bom Texto, 2004.

SANT'ANNA, Leopoldo. O football em São Paulo. Notas crítico-biográficas dos principaes jogadores paulistas antigos e modernos. São Paulo, Typographia Piratininga, 1918.

-Supremacia e decadência do futebol paulista. São Paulo,

Instituto Ana Rosa, 1925.

SANTOS, Viviane Teresinha dos. Rivoluzionari in San Paolo. A comunidade italiana e a polícia política (1924 - 1945). Dissertação de mestrado apresentada ao Depto. de História da USP, 2003.

SANTOS Neto, José Moraes. Visão do Jogo. Primórdios do futebol no Brasil. São Paulo, Cosac \& Naify, 2002.

SEABRA. Odete C. L. Urbanização e fragmentação. Cotidiano e vida de bairro na metamorfose da cidade em metrópole, a partir das transformações do bairro do Limão. São Paulo, Livre Docência apresentada ao Departamento de Geografia da FFLCH-USP, 2003.

Os meandros dos rios nos meandros do poder. Tietê $e$ Pinheiros - Valorização dos rios e das várzeas na cidade de São Paulo. Tese de doutoramento apresentada ao Departamento de Geografia da FFLCH - USP, 1987.

SEVCENKO, Nicolau. Orfeu estático na metrópole. São Paulo, Sociedade e cultura nos frementes anos 20. São Paulo, Cia.das Letras, 1992.

-Futebol, metrópoles e desatinos. (In). Revista USP $n^{o} 22$.

Dossiê Futebol. Junho, julho e agosto de 1994.

SEVCENKO, N. (Org.). História da Vida Privada no Brasil. Vol. III. República. Da Belle Epóque a Era do Rádio. São Paulo, Cia. Das Letras, 1998. 
SILVA, Marcelino Rodrigues da. Mil e uma noites de futebol. O Brasil moderno de Mário Filho. Belo Horizonte, Editora UFMG, 2006.

SMITH, Stratton. The Brazil Book of Football. Londres, Souvenir Press, 1962.

SOUZA, Kleber Mazziero de. Divino. A vida e a arte de Ademir da Guia. Rio de Janeiro, Gryphus, 2001.

TELECO. As doces recordações de um artilheiro. A gazeta esportiva, 29/09/1985, pág.30.

TOLEDO, Benedito Lima de. São Paulo. Três cidades em um século. São Paulo, Cosac \& Naify/Livraria Duas Cidades, 2004.

TOLEDO, Luiz Henrique. Torcidas organizadas de futebol. Lazer e estilo de vida na metrópole. Dissertação de mestrado apresentada ao Programa de Pós-Graduação em Antropologia Social da USP, 1994.

Lógicas no futebol. Dimensões simbólicas de um esporte nacional. São Paulo, Tese de doutorado apresentada ao Depto. de Antropologia da FFLCH/USP, 2000.

Futebol e teoria social; Aspectos da produção científica brasileira (1982-2002). Boletim informativo e bibliográfico de Ciências Sociais. Anpocs, São Paulo, n52, $2^{\circ}$ semestre de 2001, pp.133-165.

--Contribuições ao estudo da crônica esportiva 1; A "contracrônica" esportiva de Lima Barreto. Pesquisa de campo, Futebol: Síntese da vida brasileira. Rio de Janeiro, Cultural UERJ, nº 3 e 4, 1996, pp.37-50.

TRENTO, Ângelo. Do outro lado do Atlântico. Um século de imigração italiana no Brasil. São Paulo, Nobel, 1989.

UNZELTE, Celso Dario. Almanaque do Timão. São Paulo Abril, 2000.

-Timão 100 anos. 100 jogos, 100 ídolos. Belo Horizonte,

Gutemberg, 2009.

UNZELTE, Celso Dario \& VENDETTI, Mário Sérgio. Almanaque do Palmeiras. São Paulo, Abril, 2004.

VALENTIM, Max. O futebol e sua técnica. Rio de Janeiro, Alba Editora, 1958. $3^{\text {a }}$ Edição.

XAVIER, Beto. Futebol no país da música. Panda Books, São Paulo, 2009. 
WISNIK, José Miguel. Veneno Remédio. O futebol e o Brasil. São Paulo, Cia. das Letras, 2008.

WITTER, José Sebastião. Breve história do futebol brasileiro. São Paulo, FTD, 1996.

-Os esportes na cidade de São Paulo. In: Porta, Paula

(org.). História da cidade de São Paulo. A cidade no Império (1823-1889). São Paulo, Paz e Terra, 2004. 


\section{Sítios da Internet}

http://www.corinthians.com.br/2008/

http://www.palmeiras.com.br/home/index.asp

http://www.spfc.com.br/

http://sempla.prefeitura.sp.gov.br/historico/tabelas/pop_brasil.php

http://23pps.blogspot.com/2008/05/flavio-la-selva-recebe-homenagem-na.html

http://informativodafiel.blogspot.com/2008/05/20-anos-sem-flvio-la-selva.html

http://observatoriodaimprensa.com.br/artigos.asp?cod=534JDB003

http://g1.globo.com/Noticias/SaoPaulo/0,,MUL1357660-5605,00-

PREFEITURA+DE+SP+PODE+LOTEAR+AREA+OCUPADA+PELO+CLUBE+

DE+REGATAS+TIETE.html.

http://www.lancenet.com.br/noticias/10-02-21/704893.stm 


\section{Índice das imagens}

1. Ilustração na revista A Bohemia - SP $1^{\circ}$ Anno - Julho nº - Diretor José Piza

(Coleção Caio Prado Jr. - IEB - USP).

2. Planta apresentada em 1929 pelo Palestra Itália para a construção de um estádio. $A$

Gazeta Esportiva, 11/03/1929. Pág. 7. (Coleção Federação Paulista de Futebol).........

3. Jovens jogadores de futebol do bairro do Bom Retiro. À direita, Amílcar Barbuy em

início de carreira. A Gazeta Esportiva, 13/01/1930. Pág. 7. (Coleção Federação Paulista de Futebol).

4. Capa do Diário da Noite. S/D. (Coleção Caio Prado Jr. - IEB - USP).....

5. Formou-se o eixo... A Gazeta Esportiva, 07/08/1939, Capa. (Coleção particular do autor).......

6. Sede do São Paulo Futebol Clube no bairro do Canindé, em 1942. A Gazeta Esportiva. 06/04/1942. (Coleção Federação Paulista de Futebol).

7. Cromo do time do C. A. Paulistano, na década de 1920, das Balas Sportman 104 (Coleção Particular de Marcelo Dentello)

8. Desfile de inauguração do Estádio Municipal de São Paulo, em 1940. (Coleção Caio Prado Jr. - IEB - USP)

9. Leônidas da Silva executa sua jogada mais famosa: a "bicicleta". A Gazeta Esportiva. 17/05/1943. (Coleção particular do autor)

10. Partida disputada no Parque Antártica na década de 1920. Ao fundo, o pequeno cercado que separava o gramado da torcida. A Gazeta Esportiva. 09/12/1929. Pág.8. (Coleção Federação Paulista de Futebol).

11. Altino Arantes, o Tatu, alguns meses antes de morrer. A Gazeta Esportiva, 173 10/10/1931. Capa. (Coleção Federação Paulista de Futebol)

12. Romeu Augusto Nabuco, o Gibi, um dos atletas negros que despontou no futebol paulistano, a partir de 1927. A Gazeta Esportiva, 27/05/1929. Pág. 3. (Coleção Federação Paulista de Futebol).

13. Amílcar Barbuy ao término da carreira, em 1930. A Gazeta Esportiva, 13/01/1930. 186 Pág. 5 (Coleção Federação Paulista de Futebol).

14. Visita de alguns dos fundadores do S. C. Corinthians Paulista à redação do jornal $\mathrm{A}$ Gazeta Esportiva. A Gazeta Esportiva. 07/09/1930. Pág. 5. (Coleção Federação Paulista de Futebol).

15. Spartaco Bianco como treinador do Palestra Itália, em 1930. A Gazeta Esportiva, 200 24/11/1930. Capa. (Coleção Federação Paulista de Futebol). 